\title{
1988 Federal Interim Storage Fee Study: A Technical and Economic Analysis
}

November 1988

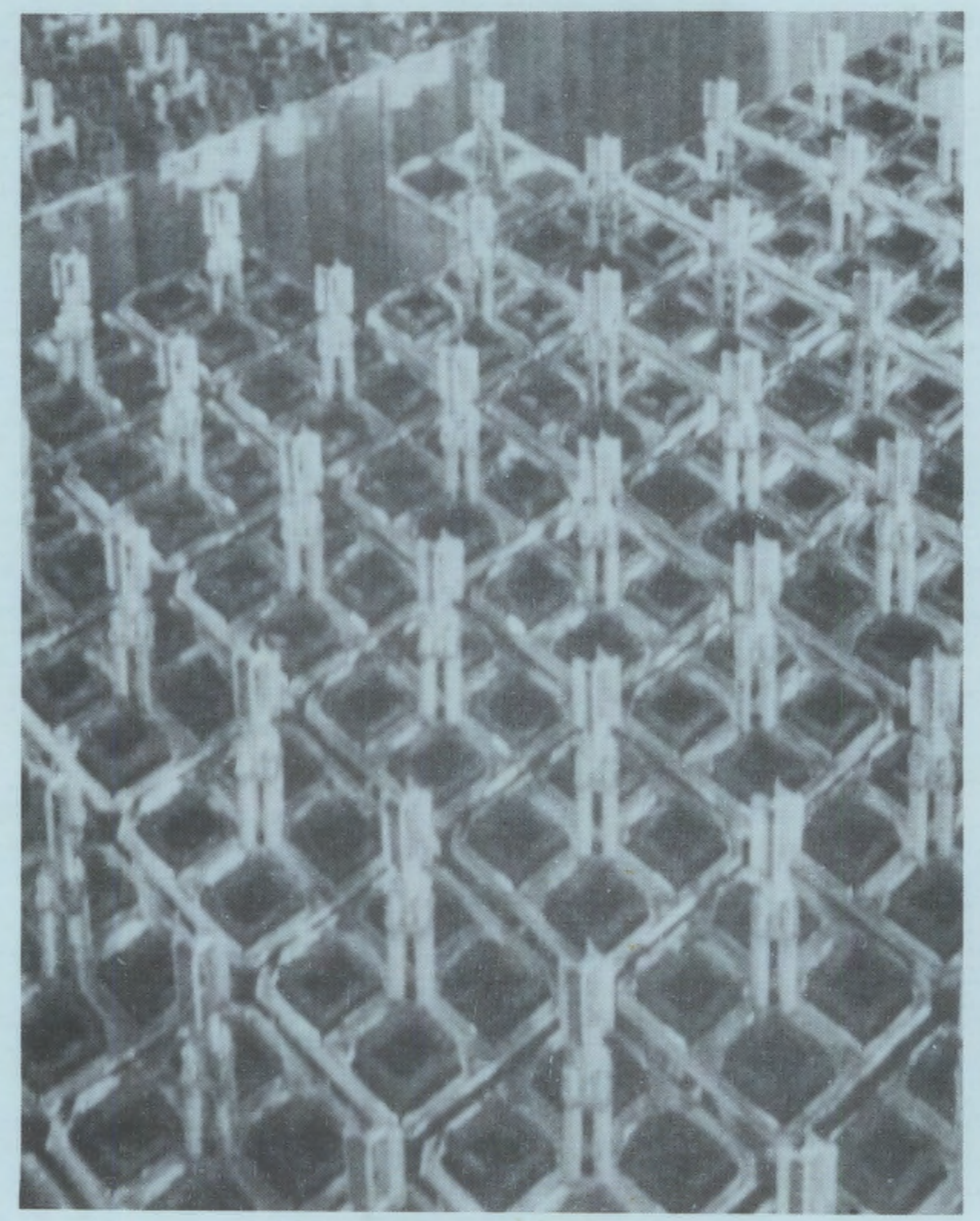

Prepared by E.R. Johnson Associates, Inc.

for Pacific Northwest Laboratory

under Contract DE-AC06-76RLO 1830

with the U.S. Department of Energy

Pacific Northwest Laboratory

Operated for the U.S. Department of Energy

by Battelle Memorial Institute 


\title{
DISCLAIMER
}

This report was prepared as an account of work sponsored by an agency of the United States Government. Neither the United States Government nor any agency thereof, nor Battelle Memorial Institute, nor any or their employees, makes any warranty, expressed or implied, or assumes any legal liability or responsibility for the accuracy, completeness, or usefulness of any information, apparatus, product, or process disclosed, or represents that its use would not infringe privately owned rights. Reference herein to any specific commercial product, process, or service by trade name, trademark, manufacturer, or otherwise does not necessarily constitute or imply its endorsement, recommendation, or favoring by the United States Government or any agency thereof, or Battelle Memorial Institute. The views and opinions of authors expressed herein do not necessarily state or reflect those of the United States Government or any agency thereof.

\author{
PACIFIC NORTHWEST LABORATORY \\ operated by \\ BATTELLE MEMORIAL INSTITUTE \\ for the \\ UNITED STATES DEPARTMENT OF ENERGY \\ under Contract DE-AC06-76RLO 1830
}

\begin{tabular}{|c|c|}
\hline \multicolumn{2}{|c|}{ Printed in the United States of America } \\
\hline \multicolumn{2}{|c|}{ Available from } \\
\hline \multicolumn{2}{|c|}{ National Technical Information Service } \\
\hline \multicolumn{2}{|c|}{ United States Department of Commerce } \\
\hline \multicolumn{2}{|c|}{5285 Port Royal Road } \\
\hline \multicolumn{2}{|c|}{ Springfield, Virginia 22161} \\
\hline \multicolumn{2}{|c|}{ NTIS Price Codes } \\
\hline \multicolumn{2}{|c|}{ Microfiche A01 } \\
\hline \multicolumn{2}{|c|}{ Printed Copy } \\
\hline & Price \\
\hline Pages & Codes \\
\hline 001-025 & $\mathrm{A} 02$ \\
\hline 026-050 & A03 \\
\hline 051-075 & $\mathrm{A} 04$ \\
\hline 076-100 & A05 \\
\hline $101-125$ & A06 \\
\hline $126-150$ & A07 \\
\hline $151-175$ & $\mathrm{~A} 08$ \\
\hline $176-200$ & $\mathrm{~A} 09$ \\
\hline $201-225$ & A10 \\
\hline $226-250$ & A11 \\
\hline $251-275$ & A12 \\
\hline $276-300$ & A13 \\
\hline
\end{tabular}


1988 FEDERAL INTERIM STORAGE FEE STUDY:

A TECHNICAL AND ECONOMIC ANALYSIS

E. R. Johnson Associates, Inc. Oakton, Virginia

November 1988

Prepared by

E. R. Johnson Associates, Inc. for Pacific Northwest Laboratory under Contract DE-ACO6-76RLO 1830 with the U.S. Department of Energy under Agreement B-L7022-A-G

Pacific Northwest Laboratory Richland, Washington 99352 


\section{ABSTRACT}

This document is the latest in a series of reports that are published annually by Pacific Northwest Laboratory (PNL) for the U.S. Department of Energy (DOE). The information in this report, which was prepared by $E . R$. Johnson Associates, Inc. under subcontract to PNL, will be used by the DOE to establish a payment schedule for interim storage of spent nuclear fuel under the Federal Interim Storage (FIS) Program. The FIS Program was mandated by the Nuclear Waste Policy Act of 1982 . The information will be used to establish the schedule of charges for FIS services for the year conmencing January 1, 1989. 



\section{CONTENTS}

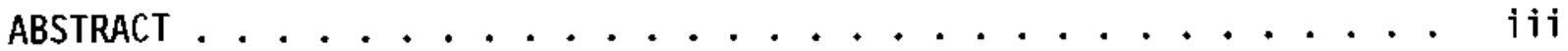

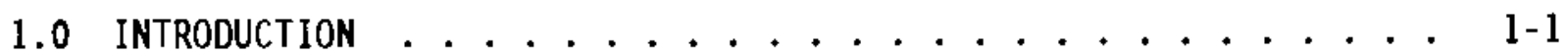

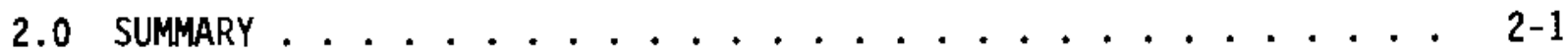

3.0 BASES FOR THE STUDY .................. . . . . . . .

3.1 STORAGE METHODS CONSIDERED . . . . . . . . . . 3-1

3.2 QUANTITIES OF SPENT FUel TO BE STORED . . . . . . . 3-2

3.3 LOCATION AND EXISTING CAPABILITIES OF FIS SITE ..... $\ldots 3-3$

3.4 SCHEDULE OF CONSTRUCTION AND OPERATION . . . . . . . . $3-4$

3.5 DEVELOPMENT OF THE FEE FOR FIS ........... . . 3-5

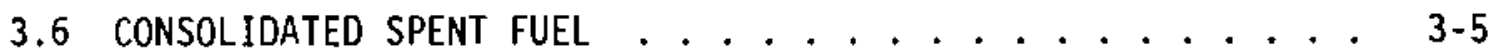

4.0 COSTS FOR FIS OF SPENT FUEL . . . . . . . . . . . . 4-1

4.1 REVIEW OF AND REVISIONS IN FIS FACILITY DESIGNS . . . . . 4-1

4.2 REVIEW OF AND REVISIONS IN 1985 FIS COST ESTIMATES . . . 4-1

5.0 COSTS FOR SPENT FUEL TRANSPORT ............. . . .

6.0 FEE METHODOLOGY AND FEE COMPUTATION . . . . . . . . . 6-1

6.1 METHOD OF FEE COLLECTION ............... . 6-1

6.2 METHOD OF COMPUTATION OF FEE ............. $6-2$

6.3 SENSITIVITY OF FEES TO CHANGES IN CONDITIONS . . . . . . 6-7

6.4 ESTABLISHMENT OF FEES FOR FIS SERVICES . . . . . . . 6.8

7.0 SPENT FUEL ACCEPTANCE CRITERIA FOR FIS . . . . . . . . . 7-1

EXHIBIT A - DESIGN DESCRIPTION AND ESTIMATED COSTS FOR THE DRY STORAGE OF SPENT NUCLEAR FUEL IN FEDERAL INTERIM STORAGE FACILITIES . . . . . . . . . . . . . . Al-1

EXHIBIT B - ESTIMATED COSTS FOR TRANSPORT OF SPENT FUEL FROM VARIOUS REACTOR SITES TO FEDERAL INTERIM STORAGE

FACILITIES . . . . . . . . . . . . . . B Bi-1

EXHIBIT $C$ - FIS SPENT FUEL ACCEPTANCE CRITERIA . . . . . . . Cl-1 


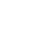




\section{$\underline{\text { IABLES }}$}

2-1 Estimate of Total Unit Charges for FIS Services at the Indicated FIS Capacity Levels for Each of the Alternative Modes of Storage and Facility Location . . . . 2-2

2-2 Estimated Initial Payment for FIS Services at the Indicated FIS Capacity Levels for EAch of the Alternative Modes of Storage ............ 2-3

2-3 Estimated Final Payment for FIS Services at the Indicated Initial FIS Capacity Levels for Each of the Alternative Modes of Storage .................

3-1 Prospective Sources of Spent Fuel for FIS . . . . . . . 3-2

4-1 Sunmary of Estimated Capital Costs for FIS Facilities Having Different Total Storage Capacities .........

4-2 Summary of Estimated Total Operating Costs for FIS Facilities Having Different Total Storage Capacities . . . . . 4-4

4-3 Summary of Estimated Special Costs for FIS Facilities Having Different Total Storage Capacities ..........

4-4 Summary of Total Discounted Costs for Construction and Operations of FIS Facilities Having Different Total Storage Capacities ............... 4-6

5-1 Summary of Estimated Costs for a Single Cask Shipment of Spent Fuel from Specific Reactor Locations to FIS Facilities

6-I Estimated Initial Payment for FIS Services at the Indicated Initial FIS Capacity Levels for Each of the Alternative Modes of Storage

6-2 Estimated Final Payment for FIS Services at the Indicated Initial FIS Capacity Levels for Each of the Alternative Modes of Storage ............... 6- 6 . .

6-3 Estimate of Total Unit Cost for FIS Services at the Indicated FIS Capacity Levels for Each of the Alternative Modes of Storage ............. 6-4

6-4 Summary of Estimated Unit Costs for Transporting Spent Fue1 from Specific Reactor Locations to FIS Facilities . . . . . . 
I988 FEDERAL INTERIM STORAGE FEE STUDY:

A TECHNICAL AND ECONOMIC ANALYSIS

$1.0 \quad$ INTRODUCTION

The Nuclear Waste Policy Act of 1982 enacted on January 7, 1983 (Pub. L. 97-425, 96 Stat. 2201, 42 U.S.C. 10101 et seq., referred to herein as "the Act") established, among other things, a Federal Interim Storage (FIS) Program for spent nuclear fuel from domestic civilian power reactors. This program is intended to ensure the continued orderly operation of such reactors where at-reactor storage cannot reasonably be provided soon enough, as determined by the Nuclear Regulatory Commission (NRC), to prevent a disruption of operations. Sec. 136(a)(2) of the Act provides that the Secretary of Energy (the Secretary) undertake a study to establish payment charges for FIS of spent fuel and report the results to Congress not later than 180 days after the date of enactment of the Act.

In accordance with this requirement, the Department of Energy (the Department) prepared and submitted a report to Congress entitled Payment Charges for Federal Interim Storage of Spent Nuclear Fuel from Civilian Nuclear Power Plants in the United States, DOE/S-0022, dated Juity 1983. The report was supplemented by a more detailed technical, contractual, and economic study and analysis which was contained in a report entitled Federal Interim Storage Fee Study for Civilian Spent Nuclear Fuel: A Technical and Economic Analysis, DOE/S-0023, dated July 1983. These reports formed the basis for the payment charges for Federal Interim Storage (FIS) services which were published in the Federal Register on December 2, 1983 and became effective on January I, 1984 (F.R. 48:54391).

Under the provisions of the Act, the Department may revise these payment charges no more frequently than annualiy to reflect changing conditions. In preparation for the possibility of a revision to the payment charges for FIS services for $1988, E$. R. Johnson Associates, Inc. (JAI) was asked to review and analyze DOE/S-0022 and DOE/S-0023 and to update the content thereof to provide a basis for the Department to establish the payment 
charges $1 /$ for FIS services in the Federal Register for the year commencing January 1, 1988. The results of this update were reported in a document entitled, 1987 Federal Interim Storage Fee Study: A Technical and Economic Analysis, PNL-6322, dated September 1987.

In preparation for the possibility of a revision to the payment charges for FIS services for 1989, JAI was asked to:

0 Review the data base of information that was used in the previous fee determinations (for 1984, 1985, 1986, 1987, and 1988).

- Prepare estimates of costs for capital, operating, and decommissioning each of the FIS facilities cases reported on in PNL-6322.

o Update spending schedules for each of the FIS facilities cases reported on in PNL-6322.

o Review the fee structure to ensure that it will recover government expenses in a way that eliminates or minimizes the need for appropriations of federal funds to provide FIS. Since it is the Department's current position that funds will not be appropriated for FIS purposes and that procurements will be authorized only from funds available in the Interim Storage Fund, it is important that the fee structure provides funds for FIS expenditures in advance of the time the expenditures are made.

o Recommend the magnitude of the fee to be collected from FIS users based on the background information and fee structure reviews noted above.

As a result of this work, JAI has updated the content of PNL $\rightarrow 6322$ to provide a basis for the Department to establish payment charges for FIS services in the Federal Register for the year commencing January 1, 1989. This report describes the results of the update which was performed.

If The terms "payment charges", "charges", "fee" and "unit cost" have been used interchangeably throughout this report and, therefore, have identical meanings. 
JAI examined alternative methods for structuring charges for FIS services and concluded that the combined interests of the Department and the users would be best served, and costs most appropriately recovered, by a twopart fee involving an Initial Payment upon execution of a contract for FIS services followed by a Final Payment upon delivery of the spent fuel to the Department.

The Initial Payment would be an advance payment covering the pro rata share of preoperational costs, including (i) the capital costs of the required transfer facilities and storage area, ( $i$ ) development costs, ( $i i i$ ) government administrative costs inciuding storage fund management, (iv) impact aid payments made in accordance with section 136(e) of the Act, and ( $v$ ) module costs (i.e., storage casks, drywells or silos).

The Final Payment would be made at the time of delivery of the spent fuel to the Department and would be calculated to cover the sum of the following:

(i) any under-or over-estimation in the costs used to calculate the Initial Payment of the fee (including savings due to rod consolidation), and

(ii) the total estimated cost of operation and decommissioning of the FIS facilities (including government administrative costs, storage fund management and impact aid).

The module costs were included in the Initial Payment to preclude the possible need to obtain appropriations for federal funds to support the purchase of the modules in advance of receipt of the Final payment.

Charges for the transport of spent fuel from the reactor site to FIS facilities would be separately assessed at actual cost since these will be specific to each reactor site and destination.

The Initial Payments received from all users would provide the funds necessary to design, license (as applicable) and construct the FIS facilities, to pay for storage modules, and to repay any funds borrowed from the U.S. Treasury that may have been needed eariier. The Final Payments received would also include an adjustment for differences between the actual preoperational costs and those used to calculate the Initial payment, and the estimated future costs of facility operation. 
JAI estimated the charges that would have to be made for the FIS of commercial spent fuel by each of three different methods of dry storage. These estimates were made for facilities having storage capacities ranging from 50-1900 MTU? at each of two different types of government sites, one which has an existing hot cell for the transfer of spent fuel from shipping casks to the storage modules, and one which does not. The determination of this range of charges was necessary inasmuch as the method of FIS has not yet been selected, the selection of a specific location(s) for FIs facilities has not been initiated, and the quantity of spent fuel which may become eligible to be stored in FIS facilities has not yet been determined. The total estimated charges developed by JAI are set forth in Table 2-1; the corresponding Initial Payments and Final Payments are set forth in Tables $\mathbf{2 - 2}$ and $2-3$.

IABLE 2-1

ESTIMATE OF THE TOTAL UN1? CHARGES FOR FIS SERVICES AT THE IMDICATED FIS CAPACITY LEVELS FOR EACH OF THE ALTERNATIVE MODES OF STORAGE ANO FACILITY LOCATION

(1989 Dollars)

Total FIS Fees ( $/ \mathrm{kgu})$

\begin{tabular}{|c|c|c|c|c|c|c|c|c|}
\hline $\begin{array}{c}\text { Capacity } \\
\text { of FIS }\end{array}$ & Exist & $\begin{array}{l}\text { ite with } \\
\text { ansfer }\end{array}$ & ities & & istif & $\begin{array}{l}\text { Site } W 1 \\
\text { ransfer }\end{array}$ & $1 i$ & \\
\hline $\begin{array}{l}\text { Facility } \\
\text { (nTU) }\end{array}$ & $\begin{array}{c}\text { Storage } \\
\text { Cask }\end{array}$ & Drymell & silo & & $\begin{array}{l}\text { rage } \\
\text { sk }\end{array}$ & Drymell & & 10 \\
\hline 50 & $\$ 1,220$ & $\$ 1,324$ & $\$ 1,251$ & $\$$ & 691 & $\$ 914$ & 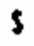 & 838 \\
\hline 100 & 697 & 730 & 697 & & 433 & 525 & & 491 \\
\hline 300 & 329 & 320 & 313 & & 242 & 251 & & 245 \\
\hline 800 & 214 & 190 & 196 & & 180 & 164 & & 168 \\
\hline 1500 & 183 & 156 & 160 & & 163 & 138 & & 143 \\
\hline 1900 & 175 & 146 & 152 & & 159 & 131 & & 137 \\
\hline
\end{tabular}

\footnotetext{
Excludes cost for transport of spent fuel since this will be specific to each reactor site and destination

based on two-thirds of the weight of uranium being contained in PWR assemblies with a 0.461 HTU loading and one-third of the weight of uranium being contalned in BHR assemblites ith 0.183 MTU loading.
}

2/MTU stands for metric tons of uranium contained in the fuel assemblies at first introduction into the reactor. kgu represents kilograms of uranium contained in the fuel assemblies at first introduction into the reactor. 1 MTU $=1000 \mathrm{kgJ}$ 
TABLE 2-2

ESTIMATED INITIAL PAYMENT FOR FIS SERVICES

AT THE INDICATED INITIAL FIS CAPACITY LEVELS FOR EACH OF JHE ALTERNATIVE MODES OF STORAGE

(1989 Dollars)

Intital Payment $(\$ / \mathrm{kgU})$

\begin{tabular}{|c|c|c|c|c|c|c|c|c|c|c|c|}
\hline \multirow{2}{*}{$\begin{array}{l}\text { Capacity } \\
\text { of Fis } \\
\text { Facility } \\
\text { (MTU) }\end{array}$} & \multicolumn{6}{|c|}{$\begin{array}{c}\text { At Site Without } \\
\text { Existing Transfer Facilities }\end{array}$} & \multicolumn{5}{|c|}{$\begin{array}{c}\text { At Site With } \\
\text { Existing Transfer Facilities }\end{array}$} \\
\hline & \multicolumn{2}{|c|}{$\begin{array}{c}\text { Storage } \\
\text { Cask }\end{array}$} & \multicolumn{2}{|c|}{ Drywell } & \multicolumn{2}{|c|}{5110} & \multicolumn{2}{|c|}{$\begin{array}{c}\text { Storage } \\
\text { Cask }\end{array}$} & \multirow{2}{*}{$\frac{\text { Drywell }}{\$ 433}$} & \multicolumn{2}{|c|}{ silo } \\
\hline 50 & $s$ & 624 & 3 & 691 & s & 642 & s & 277 & & $\$$ & 384 \\
\hline 100 & & 367 & & 382 & & 362 & & $\cdot 194$ & 253 & & 233 \\
\hline 300 & & 189 & & 173 & & 173 & & 132 & 130 & & 130 \\
\hline 800 & & 133 & & 107 & & 114 & & 111 & 91 & & 97 \\
\hline 1500 & & 118 & & 89 & & 97 & & 106 & 79 & & 88 \\
\hline 1900 & & 114 & & 84 & & 93 & & 105 & 76 & & 85 \\
\hline $\begin{array}{l}\text { aEcludes } \\
\text { each rea }\end{array}$ & co & site & $\begin{array}{l}\text { transp } \\
\text { and de }\end{array}$ & $\begin{array}{l}\text { ort } 0 \\
\text { stina }\end{array}$ & $\begin{array}{l}\text { Spent } \\
\text { on }\end{array}$ & fuel & since & this & ill be spe & & \\
\hline
\end{tabular}

TABLE 2-3

ESTIMATED FINAL PAYMENT FOR FIS SERVICES

AT THE INDICATED INITIAL FIS CAPACIIY LEVELS FOR EACK OF IHE ALTERNATIVE MODES OF STORAGE ${ }^{\mathrm{d}, \mathrm{b}}$

(1989 Dollars)

Final Payment $(\$ / \mathrm{kgU})$

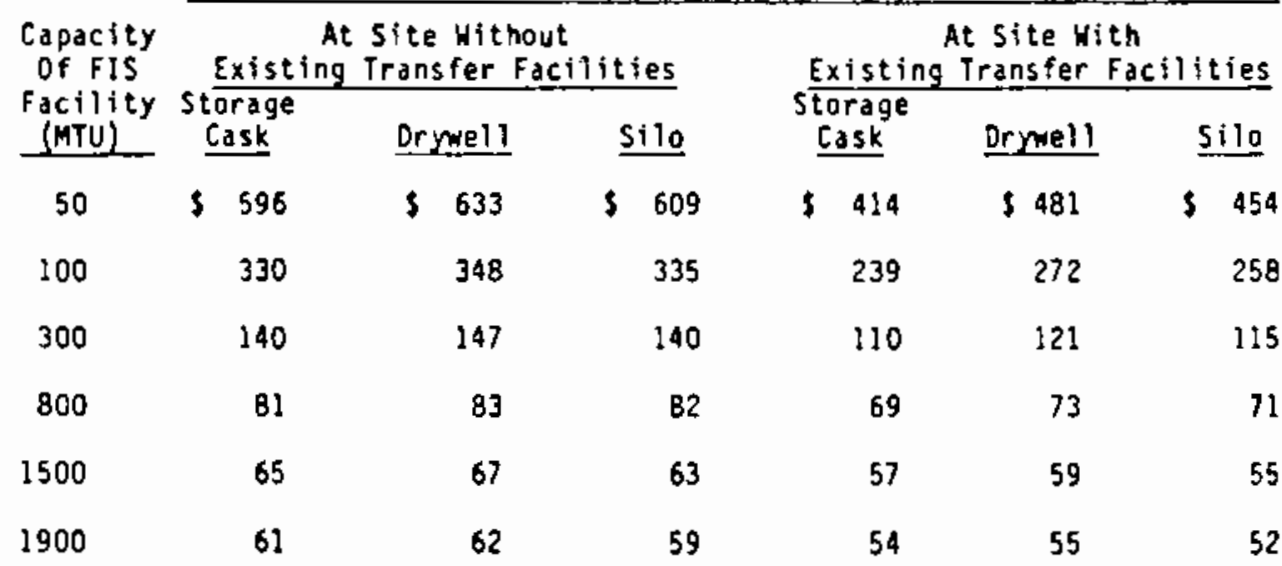

axcludes cost for transport of spent fuel since this will be specific to each reactor site and destination

based on two-thirds of the weight of uranium being contained in PWR assemblies with a 0.461 MTU loading and one-third of the reight of uranium being contained in BWR assemblies with a 0.183 MTU loading. 
The magnitude of the total unit charges set forth in Table 2-1 ranged from 3\% to $6 \%$ higher than those set forth in the 1987 report at the 1900 MTU capacity level to $12 \%$ to $15 \%$ higher at the 50 MTU capacity level. The principal cause of this increase was the assumed increase in length of the storage period as a result of the 5 year delay in the startup of the MRS facility and/or repository facility contemplated by the Draft 1988 Mission Plan Amendment (DOE/RW-0187; June 1988), which resulted in the FIS program spanning the period 1989 through 2006 rather than the period 1988 through 2001 assumed in the 1987 report. A small portion of the increase was due to escalation.

JAI also estimated the costs of transporting spent fue? between each of twelve reactor sites which are prospective candidates for FIS services and two sample locations for FIS facilities, one in the Eastern U.S. and one in the Western U.S. It was found that costs for shipments made under NRC and DOT regulations ranged from $\$ 14 / \mathrm{kgU}$ to $\$ 57 / \mathrm{kgU}$ for a FIS facility located in the Eastern U.S., and ranged from $\$ 40 / \mathrm{kgU}$ to $\$ 83 / \mathrm{kgU}$ for a FIS facility located in the Western U.S., depending on the mode of shipment involved. These estimates are subject to change because of uncertainties in shipping cask design, licensing and fabrication costs, and the possible impact of carrier deregulation.

In view of the limited amount of spent fuel that is expected to be received for FIS compared to the total amount of spent fuel stored at reactor locations, and the requirements of the Act that the Department recover the costs associated with the FIS program, it is recommended that the Department (i) establish fees for FIS and the method of collection thereof in the manner described in Section 6.0 of this report, (ii) accept only non-defective spent fuel assemblies and canistered consolidated fuel rods meeting specific acceptance criteria, (iji) require specific measurements and calculations to be made on the fuel and loaded casks delivered to the Department to support certifications with respect to the condition thereof, and (iv) obtain reimbursement for additional costs incurred as a result of its receiving defective fuel or shipping casks that are not delivered in full accordance with specific certifications required by the Department, in addition to the published charges for FIS services. 
$3.0 \quad$ BASES FOR THE STUOY

The overall bases for D0E/S-0023, PNL-5231, PNL-5559, PNL-6031, and PNL-6322 (which are subsequently referred to herein as the 1983 report, the 1984 report, the 1985 report, the 1986 report, and the 1987 report, respectively) were reviewed and evaluated with respect to applicability for establishing charges for FIS services for the calendar year 1989. The following sections summarize the bases used for establishing the 1989 charges.

\subsection{STORAGE METHODS CONSIDERED}

For the purposes of this study, JAI used the same basic assumptions with respect to the methods of storage to be considered for FIS purposes that were used in the 1983, 1984, 1985, 1986 and 1987 reports:

(1) that the Fis of spent fuel would be accomplished using dry, modular methods of storage inasmuch as these methods offer the greatest flexibility in meeting changing requirements for storage capacity, and

(2) since the Department has yet to select the specific method of storage, this study considered storage by one design each of three classes of dry, modular methods including metal storage casks, drywells (or caissons below-grade), and concrete storage silos (or caissons above-grade).

JAI continues to recommend that the Department not make the selection of a specific method for use in FIS until the first contract(s) for FIS services is executed.

While the Department has continued to consider the possibility of using existing water basin storage facilities which may be available at government sites for FIS purposes, the feasibility and economics of the use of such facilities for FIs still have not been established. Therefore, the use of such facilities has not been considered in this study as a basis for establishing payment charges for FIS services for calendar year 1989. 
3.2 QUANTITIES OF SPENT FUEL TO BE STORED

The prospective needs of utility companies for spent fuel storage are expected to amount to about 229 MTU in 1989 increasing to as much as 1286 MTU in 1995, as described in the following Table $3-1.3,4 /$

TABLE 3-1

PROSPECTIVE SOURCES OF SPENT FUEL FOR FIS

(Cumulative)

Cumulative Quantities (MTU)

Reactor

oconee 1 \& 2

Millstone 1

Palisades

St. Lucie

Crystal River

Robinson 2

Brunswick 1

La Salle $1 \& 2$

Brunswick 2

Calvert $\mathrm{Cliffs} 1 \& 2$

Prairie Island $1 \& 2$

Pilgrim

Indian Point

Total

\begin{tabular}{|c|c|c|c|c|c|c|}
\hline \multicolumn{3}{|c|}{ Cumulative } & \multicolumn{3}{|c|}{ Quantities (MTU) } & \\
\hline 1989 & 1990 & 1991 & 1992 & $\underline{1993}$ & $\underline{1994}$ & 1995 \\
\hline 133 & 157 & 181 & 205 & 229 & 253 & 276 \\
\hline 59 & 59 & 93 & 93 & 128 & 128 & 163 \\
\hline 7 & 34 & 34 & 61 & 61 & 88 & 88 \\
\hline 25 & 53 & 53 & 82 & 110 & 110 & 138 \\
\hline 5 & 5 & 5 & 38 & 38 & 38 & 71 \\
\hline 0 & 12 & 38 & 38 & 59 & 59 & 79 \\
\hline 0 & 0 & 26 & 26 & 59 & 59 & 93 \\
\hline 0 & 0 & 25 & 66 & 106 & 186 & 186 \\
\hline 0 & 0 & 0 & 5 & 5 & 38 & 38 \\
\hline 0 & 0 & 0 & 0 & 36 & 36 & 72 \\
\hline 0 & 0 & 0 & 0 & 0 & 23 & 39 \\
\hline 0 & 0 & 0 & 0 & 0 & 0 & 29 \\
\hline 0 & $\underline{0}$ & 0 & 0 & 0 & 0 & 14 \\
\hline 229 & 320 & 455 & 614 & 831 & 1018 & 1286 \\
\hline
\end{tabular}

3/ Department of Energy. October 1988. Spent Fuel Storage Requirements 1988. DOE/RL-88-34. Richland Operations Office, Richland, Washington.

4/ If a requirement for FIS services occurs before 1991 , this requirement would be met by temporary storage at existing Department facilities. 
However, it may be possible for many, if not all, of the utility companies which have the expected shortfall in spent fuel storage capacity to meet all or part of their additional storage needs through transshipments, rod consolidation $5 /$, installation of additional capacity at reactor sites, or combinations thereof. Moreover, the NRC may, during the determination of eligibility, find that much of the spent fuel currently forecast to exceed available on-site storage capacity will not qualify for FIS.

In view of the uncertainties associated with predicting the amount of spent fuel to be received for FIS, this study considered storage in facilities having the following nominal capacities for each of the storage methods considered up to the 1 imitation of 1900 MTU as established by the Act:
(1) 50 MTU
(4) $800 \mathrm{MTU}$
(2) $100 \mathrm{MTU}$
(5) 1500 MTU
(3) 300 MTU
(6) 1900 MTU

\subsection{LOCATION AND EXISTING CAPABILITIES OF FIS SITE}

As in the 1983, 1984, 1985, 1986 and 1987 studies, this study continued to consider the use of two generic types of government sites -- one assumed to have existing facilities for transferring spent fuel from shipping casks to storage modules, and a second without such facilities. It was assumed that NRC licensing would apply to all FIS activities except the modification and operation of an existing transfer facility. JAI aiso estimated the costs involved in shipping spent fuel to sites in both the Eastern and the Western U.S. A site for FIS of spent fuel probably will not be specified until there are clear indications that FIS services will be required.

JAI reviewed the prospect of locating FIS facilities at reactors, as permitted by Sec. $135(\mathrm{a})(\mathrm{I})(\mathrm{B})$ and $(\mathrm{C})$ of the Act, but concluded that the Department probably could not develop storage capability at such locations sooner than utility companies acting on their own. For these and the other reasons set forth in the 1983, 1984, 1985, 1986 and 1987 reports, the possibility of locating FIS facilities at reactors was not considered further in this study.

5/Rod consolidation consists of removing fuel rods from the fuel assembly structure and placing them in a safe, close-packed array (in canisters) that occupies less space than the original fuel assembly. 


\subsection{SCHEDULE OF CONSTRUCTION AND OPERATION}

For the purposes of factoring the time value of money into the fee calculations of this study, JAI assumed the following concerning the schedule of constructing and operating FIS facilities in developing the revenue/expenditure schedules:

(1) Design, licensing (as applicable) and construction of FIS facilities would commence in 1989 and be completed so that storage operations could commence in mid-1992.

(2) The FIS facility would receive spent fuel during the threeyear period between mid-1992 and mid-1995. It would ship spent fuel to a Monitored Retrievabie Storage (MRS) facility or waste repository during the three-year period commencing at the beginning of 2003 and terminating at the end of 2005 . One third of the storage capacity of the FIS facility would be received each year during the receiving period, and one-third would be shipped each year during the shipping period.

(3) Decontamination and decommissioning of FIS facilities would be conducted in the year 2006.

This schedule represents a one-year delay in the start of the FIS program over that used in the 1987 report inasmuch as the program has been assumed to start one year later, but ends 5 years later than that assumed in the 1987 report as a result of a delay in the repository program. The Oraft 1988 Mission Plan Amendment (DOE/RW-0187) that was issued in June 1988 stated that:

"Schedules based on meeting the requirements of the Amendments Act show that the MRS facility should be available no later than 2003 and the repository will begin accepting waste in 2003."

Moreover, sec. 135(e) of the Act stated that any spent nuclear fuel stored under the FIS program was to be removed from FIS facilities no later than three years following the date upon which either a repository or MRS facility is available for disposal of spent nuclear fuel. Thus, for the purposes of this report, it was assumed that all fuel would be removed from FIS facilities by the end of 2005 . 


\subsection{DEVELOPMENT OF THE FEE FOR FIS}

The same basic assumptions concerning the development of charges for FIS of spent fuel were used by JAI in this study as were used in the development of the 1987 report, as follows:

(1) The charges for FIS would include the cost of

(a) design, licensing and construction of FIS facilities,

(b) storage modules,

(c) research and development solely related to the development of FIS facilities,

(d) operating costs which are incremental to the operation of the government site(s) at which the FIS facilities are located,

(e) government administration associated with FIS of spent fuel, including storage fund management,

(f) impact aid, and

(g) decontamination and decommissioning of the FIS facilities at the end of their useful iife.

(2) The charges for transport of spent fuel from the reactor locations to the FIS facilities would be separately included inasmuch as they would be specific to each point of origin and destination, and would be charged directly to the utility.

(3) The fee developed for FIS of spent fuel would cover all costs of the FIS system for storage as aforementioned through the year 2005 and for the decommissioning period.

3.6 CONSOLIDATED SPENT FUEL

For this study JAI continued to assume that canistered consolidated spent fuel rods would be acceptable for storage at the FIS facilities, but that consolidation would not be a criterion for acceptance, nor would the disassembly and consolidation of spent fuel be included in the capabilities of the FIS facilities. It would be expected that the Department would collect the same fee for storage of canistered consolidated spent fuel rods as for intact fuel assemblies until the cost effects of storing consolidated fuel become known. However, the cost of transporting consolidated spent fuel rods from the reactors to FIS facilities is expected to be about 0.6 of that 
involved in transporting intact fuel assemblies and, therefore, would result in a significant reduction in costs for utilities sending consolidated spent fuel to FIS. 
4.0 COSTS FOR FIS OF SPENT FUEL

4.1 REVIEW OF AND REVISIONS IN FIS FACILITY DESIGNS

In the development of the 1984 report, there were several design changes made to FIS facilities. During the course of this study a review was made of the resultant facility designs used in the 1984 report and it was concluded that no further design changes were either necessary or desirable for the development of FIS payment charges for 1989.

\subsection{REVIEW OF AND REVISIONS IN 1985 FIS COST ESTIMATES}

The estimates of the capital costs for transfer facilities and storage areas used in the development of the 1983 report, portions of which were modified in the 1984 report, were escalated to 1989 dollars using applicable cost indexes.

The estimates of the cost of concrete silos and canisters, and the estimates of government administration costs which were used in the development of the this report, were the same as those used for the 1983 report, escalated to 1989 dollars using applicable cost indexes. The estimate of the cost of drywells used in the development of this report were the same as those used for the 1984 report, escalated to 1989 dollars using applicable cost indexes. The estimates of cost of metal storage casks was derived from 1987 cost estimates obtained from cask design firms. For the purposes of this report, these 1987 costs were escalated to 1989 dollars.

The estimates of operating costs used in the development of the this report were were the same as those developed in the 1983 report, escalated to 1989 dollars. However, the time period for storage under the FIS program was extended to mid-1989 through 2005 in this report from the mid-1988 through 2000 period assumed in the 1987 report as a result of (i) the 5 -year delay in repository or MRS facility availability projected by the Draft 1988 Mission Plan Amendment (00E/RW-0187; June 1988), and (ii) an assumed I-year later startup of FIS facilities.

The estimates of FIS development costs set forth in the 1983 report were reviewed and it was concluded that the same estimates would be applicable for use herein, escalated to 1989 dollars. 
A description of the alternative facility designs, details of the associated cost estimates, and FIS system spending schedules are set forth in Exhibit A of this report.

Table 4-1 sets forth the total capital costs for the cases studied. The capital costs include (i) the cost of the transfer/encapsulation facilities, or modifications to existing hot cell facilities which can be used for transfer/encapsulation, ( $i i)$ the cost of the storage area, and ( $i i i$ ) the cost of the storage modules.

TABLE 4-1

SUMMARY OF ESTIMATED CAPITAL COSTS FOR FIS FACILITIES

HAVING DIFFERENT TOTAL STORAGE CAPACITIES ${ }^{\text {a }}$

(\$-millions, 1989)

Total Capital Cost

\begin{tabular}{|c|c|c|c|c|c|c|}
\hline \multirow{2}{*}{$\begin{array}{c}\text { Capacity } \\
\text { of FIS } \\
\text { Facjlity } \\
\text { (MTU) }\end{array}$} & \multicolumn{3}{|c|}{$\begin{array}{c}\text { At Site Without } \\
\text { Existing Transfer Facilities }\end{array}$} & \multicolumn{3}{|c|}{$\begin{array}{c}\text { At Site with } \\
\text { Existing Transfer Facilities }\end{array}$} \\
\hline & $\begin{array}{c}\text { Storage } \\
\text { Cask }\end{array}$ & Drywell & silo & $\begin{array}{c}\text { Storage } \\
\text { Cask }\end{array}$ & Drywell & Sito \\
\hline 50 & $\$ 28.1$ & $\$ 31.5$ & $\$ 29.0$ & $\$ 10.1$ & $\$ 18.2$ & $\$ 15.6$ \\
\hline 100 & 33.5 & 34.9 & 32.8 & 15.5 & 21.6 & 19.5 \\
\hline 300 & 54.0 & 48.4 & 48.5 & 35.9 & 35.1 & 35.2 \\
\hline 800 & 104.5 & 82.0 & 87.5 & 86.5 & 68.6 & 74.1 \\
\hline 1500 & 176.5 & 128.8 & 142.0 & 158.5 & 115.4 & 128.7 \\
\hline 1900 & 217.4 & 155.5 & 173.2 & 199.3 & 142.2 & 159.8 \\
\hline
\end{tabular}

Based on two-thirds of the weight of uranium being contained in PWR assemblies with a 0.461 MTU loading and one-third of the weight of uranium being contained in 8WR assemblies with a 0.183 MTU loading.

From the capital cost data shown in Table 4-1, it can be seen that for the lower capacities (less than 100 MTU) the capital cost of storage cask facilities is the lowest while the drywell facilities are the highest. However, at the higher capacities (more than 300 MTU) the capital cost of 
drywell facilities is the lowest while the storage cask facilities are the highest. This is due to the following:

(1) the cost of the transfer facilities is lower in the case of storage casks than for the other two cases

(2) the cost of the storage area is lowest for the cask and highest for the drywell because of the larger size of the latter

(3) the cost of modules is lowest for the drywell and highest for the cask

(4) at higher capacities, the cost advantages described in (1) and (2), above, are more than offset by the higher module cost of the storage casks.

The capital costs for all cases are obviously less where an existing facility exists which can be modified for transfer/encapsulation purposes. However, cask storage requires considerably less modification to an existing facility (hot cell) than the other modes of storage since no encapsulation facilities are required.

Table 4-2 sets forth the total operating costs for the cases studied. 
TABLE 4-2

SUMMARY OF ESTIMATED TOTAL OPERATING COSTS FOR FIS FACILITIES

HAVING DIFFERENT TOTAL STORAGE CAPACITIES ${ }^{\mathrm{a}}$

(\$-millions, 1989)

Total Operating Cost

\begin{tabular}{|c|c|c|c|c|c|c|}
\hline \multirow{2}{*}{$\begin{array}{l}\text { Capacity } \\
\text { Of FIs } \\
\text { Facility } \\
\text { (MTU) }\end{array}$} & \multicolumn{3}{|c|}{$\begin{array}{l}\text { At Site Without } \\
\text { Existing Transfer Facilities }\end{array}$} & \multicolumn{3}{|c|}{$\begin{array}{l}\text { At Site With } \\
\text { Existing Transfer Facilities }\end{array}$} \\
\hline & $\begin{array}{l}\text { Storage } \\
\text { Cask }\end{array}$ & Orywell & Silo & $\begin{array}{l}\text { Storage } \\
\text { Cask }\end{array}$ & Drywell & $\underline{\operatorname{sil}}$ \\
\hline 50 & $\$ 31.2$ & $\$ 33.3$ & $\$ 32.0$ & $\$ 20.6$ & $\$ 24.4$ & $\$ 22.9$ \\
\hline 100 & 33.0 & 35.0 & 33.6 & 22.4 & 26.1 & 24.6 \\
\hline 300 & 39.6 & 41.5 & 39.5 & 29.0 & 32.6 & 30.5 \\
\hline 800 & 57.7 & 58.6 & 58.4 & 46.3 & 49.5 & 47.6 \\
\hline 1500 & 84.8 & 86.3 & 81.2 & 71.4 & 74.4 & 69.1 \\
\hline 1900 & 100.2 & 102.1 & 94.2 & 85.6 & 88.6 & 81.5 \\
\hline
\end{tabular}

From the operating costs shown in Table 4-2, it can be seen that the operating costs associated with storage casks are the lowest for the lower capacity facilities (800 MTU and less), while those associated with the silos are the lowest for the higher capacity facilities (more than 800 MTU). Operating costs at the site with an existing transfer facility are lower than those at a site where a complete transfer facility has to be built, inasmuch as in the latter case it was assumed that a small caretaker operation would be required during the storage-only period for the new facility, whereas in the former case it was assumed that the existing facility would either find other use during the storage-only period or otherwise would have incurred caretaker expense in the absence of the FIS facility located at the site. 
Table 4-3 sets forth the total costs of special charges which are applicable to each of the cases studied. These include (i) research and development costs associated with the development of the FIS facilities, (ii) government administration costs for the FIS program including storage fund management, and (iii) impact aid.

TABLE 4-3

SUMMARY OF ESTIMATED SPECIAL COSTS FOR FIS FACILITIES

HAVING DIFFERENT TOTAL STORAGE CAPACITIES ${ }^{\mathrm{a}}$

(\$-millions, 1989)

Total Special Cost

\begin{tabular}{|c|c|c|c|c|c|c|c|}
\hline $\begin{array}{c}\text { Capacity } \\
\text { of FIS }\end{array}$ & Exist & $\begin{array}{l}\text { ite With } \\
\text { ansfer }\end{array}$ & ities & Existi & $\begin{array}{l}\text { Site Wi } \\
\text { ransfer }\end{array}$ & & ies \\
\hline $\begin{array}{l}\text { Facility } \\
\text { (MTU) } \\
\end{array}$ & $\begin{array}{c}\text { Storage } \\
\text { Cask }\end{array}$ & Drywel? & Silo & $\begin{array}{c}\text { Sorage } \\
\text { Cask }\end{array}$ & Drywell & & i10 \\
\hline 50 & $\$ 7.0$ & $\$ 7.0$ & $\$ 7.0$ & $\$ 7.0$ & $\$ 7.0$ & $\$$ & 7.0 \\
\hline 100 & 9.4 & 9.4 & 9.4 & 9.4 & 9.4 & & 9.4 \\
\hline 300 & 14.7 & 14.7 & 14.7 & 14.7 & 14.7 & & 14.7 \\
\hline 800 & 25.9 & 25.9 & 25.9 & 25.9 & 25.9 & & 25.9 \\
\hline 1500 & 40.5 & 40.5 & 40.5 & 40.5 & 37.5 & & 39.0 \\
\hline 1900 & 48.5 & 46.6 & 48.5 & 48.5 & 42.8 & & 44.7 \\
\hline
\end{tabular}

${ }^{a}$ Based on two-thirds of the weight of uranium being contained in PWR assemblies with a 0.461 MTU loading and one-third of the weight of uranium being contained in BWR assemblies with a 0.183 MTU loading.

From Table 4-3 it can be seen that special costs remain the same at a given capacity for a 11 modes of storage through the 800 MTU capacity level. This is due to the fact that the FIS development costs are the same for all cases, the government administration costs are the same at each capacity level, and the impact aid is fixed at $\$ 15 / \mathrm{kg} U$. The Act establishes a maximum for impact aid amounting to $\$ 15 / \mathrm{kg} \mathrm{U}$ or $10 \%$ of all costs, whichever is smaller. In the capacity cases through 800 MTU, $10 \%$ of the costs is higher than $\$ 15 / \mathrm{kg} \mathrm{U}$, thus $\$ 15 / \mathrm{kg} \mathrm{U}$ was used in these cases. However, in some of the cases above the 800 MTU capacity level, $10 \%$ of the costs is lower than $\$ 15 / \mathrm{kg} U$ and was used, thus producing a variation among the cases considered at these capacity levels. 
Table 4-4 sets forth the total discounted costs of construction and operation of the FIS storage system for each of the cases studied. These costs include the sum of all capital costs, operating costs and special costs (except impact aid) -- discounted to 1989 at 2 percent/year.

TABLE 4-4

SUMMARY OF TOTAL DISCOUNTEO COSTS FOR CONSTRUCTION AND OPERATIONS

OF FIS FACILITIES HAVING DIFFERENT TOTAL STORAGE CAPACITIES ${ }^{a}, b$

(\$-millions, 1989)

Total Discounted Costs (Discounted o $2 \% /$ yr to 1989 )

\begin{tabular}{|c|c|c|c|c|c|c|}
\hline \multirow{2}{*}{$\begin{array}{c}\text { Capacity } \\
\text { Of FIS } \\
\text { Facility } \\
\text { (MTU) } \\
\end{array}$} & \multicolumn{3}{|c|}{$\begin{array}{l}\text { At Site Without } \\
\text { Existing Transfer Facilities }\end{array}$} & \multicolumn{3}{|c|}{$\begin{array}{l}\text { At Site with } \\
\text { Existing Transfer Facilities }\end{array}$} \\
\hline & $\begin{array}{l}\text { Storage } \\
\text { Cask }\end{array}$ & Drywe 11 & Silo & $\begin{array}{l}\text { Storage } \\
\text { Cask }\end{array}$ & Drywell & $\underline{\text { Silo }}$ \\
\hline 50 & $\$ 57.8$ & $\$ 62.8$ & $\$ 59.2$ & $\$ 32.1$ & $\$ 42.9$ & $\$ 39.2$ \\
\hline 100 & 65.5 & 68.7 & 65.5 & 39.8 & 48.8 & 45.5 \\
\hline 300 & 91.1 & 88.0 & 86.3 & 65.5 & 68.1 & 66.3 \\
\hline 800 & 154.4 & 135.3 & 139.9 & 128.0 & 115.3 & 118.5 \\
\hline 1500 & 244.5 & 203.5 & 211.0 & 216.5 & 181.2 & 188.5 \\
\hline 1900 & 295.4 & 242.2 & 251.3 & 266.5 & 218.5 & 228.3 \\
\hline
\end{tabular}

Based on two-thirds of the weight of uranium being contained in PWR assemblies with a 0.461 MTU loading and one-third of the weight of uranium being contained in BWR assemblies with a 0.183 MTU loading.

boes not include impact aid.

From the total discounted costs shown in Table 4-4, it can be seen that for the lower capacities (50-100 MTU and less) the cost of storage in storage casks is less than the other two cases, with the cost of storage in drywells being the highest. However, for the higher capacities (800 MTU and more), the cost of storage in dry wells is less than the other two cases, with the cost of storage in storage casks being the highest. The aforementioned relationships apply to both cases where transfer facilities exist at the FIS site and where they do not so exist, the total costs for storage by a11 storage methods are lower in the former case than they are in the latter. 


\subsection{COSTS FOR SPENT FUEL TRANSPORT}

Estimates were made of the cost of transporting spent fuel from each of the prospective reactor locations identified in Table 3-1 of this report and FIS facility sites in the Eastern U.S. and the Western U.S. Estimated costs were developed for both truck transport and for rail transport, however, rail shipments should be used to the maximum extent feasible inasmuch as the larger payload of the rail casks significantly reduces the number of shipments and the amount of cask handling at both the reactor site and the FIS facilities.

Table 5-1 sets forth the estimated total cost of a single shipment of spent fuel between the various points of origin and destination considered in this study. 
TABLE 5-1

SUMMARY OF ESTIMATED COSTS FOR A SINGLE CASK SHIPMENT OF SPENT

FUEL FROM SPECIFIC REACTOR LOCAIIONS TO FIS FACILITIES

(1989 Dollars)

Reactor to Destination

From Oconee to

Eastern U.S. Site

Western U.S. Site

From Millstone to Eastern U.S. Site Western U.S. Site

From Palisades to Eastern U.S. Site Western U.S. Site

From St. Lucie to Eastern U.S. Site Western U.S. Site

From Crystal River to Eastern U.S. Site Western U.S. Site

From Robinson to Eastern U.S. Site Western U.S. Site

From Brunswick to Eastern U.S. Site Western U.S. Site

From LaSalle to Eastern U.S. Site Western U.S. Site

From Calvert Cliffs to Eastern U.S. Site Western U.S. Site

From Prairie Island to Eastern U.S. Site Western U.S. Site

From Pilgrim to Eastern U.S. Site Western U.S. Site

From Indian Point to Eastern U.S. Site Western U.S. Site
Total Cost for Shipment

Iruck Shipments $^{a}$ Rail Shipments

$\$ 6,472$

$\$ 119,460$

27,145

231,722

12,380

171,936

28,941

254,279

10,050

117,526

20,614

207,148

12,043

155,453

31,270

264,413

10,269

131,413

32,815

238,290

7,531

91,807

31,174

227,885

9,286

104,455

30,536

240,472

9,316

110,422

18,206

196,378

9,510

132,536

27,035

247,207

13,953

158,655

18,546

174,749

12,856

29,485

188,662

258,498

14,453

159,834

28,551

aased on use of NLI I/2 truck cask with capacity for either one PWR or two BWR fuel assemblies.

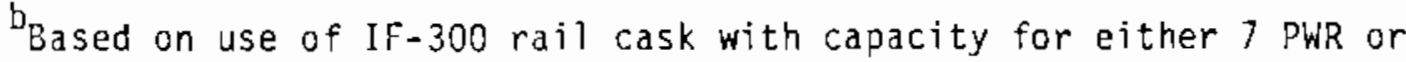
18 BWR fuel assemblies. 
6.0 FEE METHODOLOGY AND FEE COMPUTATION

6.1 METHOD OF FEE COLLECTION

JAI has reviewed the proposed method of fee collection set forth in the $1983,1984,1985,1986$ and 1987 reports and the alternative methods that were considered therein, and has concluded that the combined interests of the Department and the FIS users would still be best served by a two-part fee involving an Initial payment upon execution of a contract for FIS services, followed by a Final payment upon delivery of the spent fuel to the Department.

The Initial Payment represents an advance payment to cover the pro rata share of preoperational costs, including:

- the capital costs of the required transfer facilities and storage area

- module costs (i.e., storage casks, drywells, or silos)

0 development costs

- government administrative costs including storage fund management

- impact aid payments made in accordance with section 136(e) of the Act, and

- interest on any Treasury funds advanced to the FIS program.

The Final Payment would cover the sum of the following:

0 any under- or over-estimation in the costs used to caiculate the Initial Payment of the fee (including savings due to rod consolidation)

- transportation costs (including cask lease, freight, handling and security) ${ }^{\star}$, and

- the total estimated cost of operation and decommissioning of the FIS facilities (including government administrative costs, storage fund management and impact aid)

*This cost is not included in the FIS payment charges schedule which is issued annually by DOE. 
The Initial Payment received from all users would be calculated to provide the funds necessary to design, license (where applicable) and construct the FIS facilities, purchase storage modules, and repay any funds borrowed from the U.S. Treasury that may have been needed earlier. The Final Payments received would also include an adjustment for differences between the actual preoperational costs and those used to calculate the Initial Payment, and the estimated future costs of facility operation and decommissioning.

\subsection{METHOD OF COMPUTATION OF FEE}

The same method for computation of the fees for FIS services as was described in the 1983, 1984, 1985, 1986 and 1987 reports was used in this study. This method is summarized below:

(1) In order to effect the recovery of costs incurred by the Department in providing FIS services, the fees for such services must be established such that the sum of the discounted costs of providing the services is equal to the sum of the discounted revenues received by the Department for such services, as follows:

Discounted Costs $=$ Discounted Revenues

Discounted Revenues $=$ Discounted (Unit Fee $\times$ Units of Storage)

Discounted (Unit Fee $x$ Units of Storage) $=$ Unit Fee $x$ Discounted Units of Storage

(2) Since the fee is an unknown in the above equations, but the units of storage (MTU or numbers of modules) and estimated costs are known, the fee can be calculated by the following:

Unit Fee $=\frac{\text { Discounted Costs }}{\text { Discounted Units of Storage }}$

(3) Since it has been determined that a two-part fee for FIS services is desirable, and since a two-part fee would provide all required funds for the FIS of spent fuel either in advance of or at the same time that the corresponding component of cost of storage would be incurred, it is necessary to employ a discount rate equal to the "real" value of money, i.e., the value of money to the government net of escalation. The discount factor established by JAI for this purpose is 1.02 (or a $2 \%$ /year discount rate). 
Using the costs deveroped in Exhibit $A$, Section 9.0, the Initial Payments, Final. Payments and total payments estimated to be required in 1989 dollars for the FIS of spent fuel are set forth in Tables 6-1, 6-2 and 6-3, respectively -- for each of the three methods of storage, at the six different levels of capacity, and the two different types of locations considered in this study. The costs of transport of the spent fuel from the various prospective reactor locations to two typical FIS facility locations have been excluded from the unit costs set forth in these tables but have been shown separate $y$ in Table 6-4.

$\frac{\frac{\text { TABLE 6-1 }}{\text { ESTIMATED INITIAL PAYMENT FOR FIS SERVICES }}}{\frac{\text { THE INDICATED INITIAL FIS CAPACITY LEVELS FOR EACH OF THE }}{\text { ALTERNATIVE MODES OF STORAGE }^{\mathrm{a}, \mathrm{b}}}}$

Initial Payment $(\$ / \mathrm{kg})$

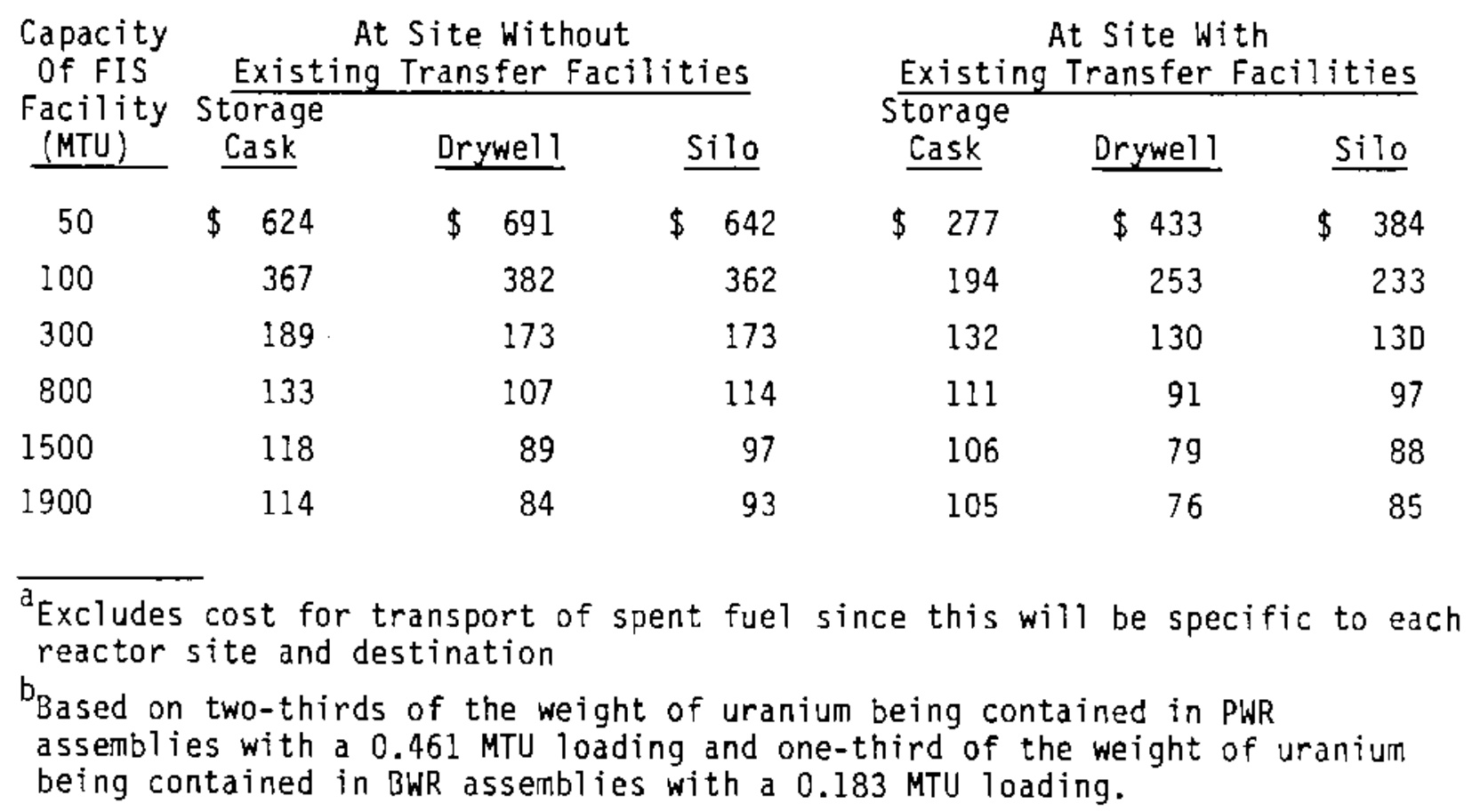


TABLE 6-2

ESTIMATED FINAL PAYMENT FOR FIS SERVICES

AT THE IHOICATED INITIAL FIS CAPACITY LEVELS FOR EACH OF THE

ALTERNATIVE MODES OF STORAGE ${ }^{2}, b$

(1989 Dollars)

Final Payment $(\$ / \mathrm{kgu})$

\begin{tabular}{|c|c|c|c|c|c|c|c|c|c|c|}
\hline \multirow{3}{*}{$\begin{array}{l}\text { Capacity } \\
\text { Of Fis } \\
\text { Facility } \\
\text { (MTU) } \\
50\end{array}$} & \multicolumn{5}{|c|}{$\begin{array}{c}\text { At Site Without } \\
\text { Existing Transfer Facilities }\end{array}$} & \multicolumn{5}{|c|}{$\begin{array}{c}\text { At Site With } \\
\text { Existing Transfer Facillties }\end{array}$} \\
\hline & $\begin{array}{l}\text { Storage } \\
\text { Cask }\end{array}$ & \multicolumn{2}{|c|}{ Dryell } & \multicolumn{2}{|c|}{ Silo } & \multicolumn{2}{|c|}{$\begin{array}{l}\text { storage } \\
\text { Cask }\end{array}$} & \multirow{2}{*}{$\frac{\text { Dryell }}{\$ 481}$} & \multicolumn{2}{|c|}{ Silo } \\
\hline & 596 & \$ & 633 & $\$$ & 609 & 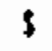 & 414 & & $\$$ & 454 \\
\hline 100 & 330 & & 348 & & 335 & & 239 & 272 & & 258 \\
\hline 300 & 140 & & 147 & & 140 & & 110 & 121 & & 115 \\
\hline 800 & 81 & & 83 & & 82 & & 69 & 73 & & 7 \\
\hline 1500 & 65 & & 67 & & 63 & & 57 & 59 & & 55 \\
\hline 1900 & 61 & & 62 & & 59 & & 54 & 55 & & 52 \\
\hline
\end{tabular}

Excludes cost for transport of spent fuel since this will be specific to each reactor site and destination

based on two-thirds of the weight of urantum being contained in PUR assemblies with a 0.461 MTU loading and one-third of the weight of uranium being contained in BWR assemblies with a 0.183 MTU loading.

TABLE 6-3

ESTIMATED TOTAL UHIT COST FOR FIS SERVICES

AT THE INDICATED INITIAL FIS CAPACITY LEVELS FOR EACH OF THE ALTERNATIVE MODES OF 5TORAGE ${ }^{2, b}$

(1989 Dollars)

Total \&IS Fees $(\$ / \mathrm{kgU})$

\begin{tabular}{|c|c|c|c|c|c|c|c|c|}
\hline \multirow{3}{*}{$\begin{array}{l}\text { Capacity } \\
\text { of Fis } \\
\text { Facility } \\
\frac{\text { (MTU) }}{50}\end{array}$} & \multicolumn{3}{|c|}{$\begin{array}{c}\text { At Site lithout } \\
\text { Existing Transfer Focilities }\end{array}$} & \multicolumn{5}{|c|}{$\begin{array}{c}\text { At Site With } \\
\text { Existing Transfer Facilities }\end{array}$} \\
\hline & \multirow{2}{*}{$\begin{array}{c}\text { Storage } \\
\text { Cask } \\
\$ 1,220\end{array}$} & \multirow{2}{*}{$\frac{\text { Drmel }}{\$ 1,324}$} & \multirow{2}{*}{$\frac{5 i 10}{\$ 1,251}$} & \multicolumn{2}{|c|}{$\begin{array}{l}\text { Storage } \\
\text { Cask }\end{array}$} & \multirow{2}{*}{$\frac{\text { Ormell }}{\$ 914}$} & \multicolumn{2}{|c|}{ silo } \\
\hline & & & & $\$$ & 691 & & 8 & 838 \\
\hline 100 & 697 & 730 & 697 & & 433 & 525 & & 491 \\
\hline 300 & 329 & 320 & 313 & & 242 & 251 & & 245 \\
\hline 800 & 214 & 190 & 196 & & 180 & 164 & & 168 \\
\hline 1500 & 183 & 156 & 160 & & 163 & 138 & & 143 \\
\hline 1900 & 175 & 146 & 152 & & 159 & 131 & & 137 \\
\hline \multicolumn{9}{|c|}{$\begin{array}{l}\text { axcludes cost for transport of spent fuel since this will be specific to } \\
\text { each reactor site and destination }\end{array}$} \\
\hline $\begin{array}{l}\mathrm{b}_{\text {Based on }} \\
\text { assenbly } \\
\text { being co }\end{array}$ & $\begin{array}{l}\text { two-thi } \\
\text { es with } \\
\text { ntained }\end{array}$ & $\begin{array}{l}f \text { the we } \\
61 \text { MTU } 1 \\
R \text { assemb }\end{array}$ & of urar & & iv of & $\begin{array}{l}\text { ned in } P \\
\text { weight }\end{array}$ & & \\
\hline
\end{tabular}


TABLE 6-4

SUMMARY OF ESTIMATED UNIT COSTS FOR TRANSPORTING SPENT FUEL FROM SPECIFIC REACTOR LOCATIONS TO FIS FACILITIES ${ }^{\mathrm{a}}$

(1989 Dollars)

Reactor to Destination

From Oconee to Eastern U.S. Site Western U.S. Site

From Millstone to Eastern U.S. Site Western U.S. Site

From Palisades to Eastern U.S. Site Western U.S. Site

From St. Lucje to Eastern U.S. Site Western U.S. Site

From Crystal River to Eastern U.S. Site Western U.S. Site

From Robinson to Eastern U.S. Site Western U.S. Site

From Brunswick to Eastern U.S. Site Western U.S. Site

From LaSalle to Eastern U.S. Site Western U.S. Site

$\frac{\text { Total Cost for Shipment }(\$ / \mathrm{kgU})}{\text { By Truck }^{\mathrm{B}}}$

$\$ 14.04$

58.88

$\$ 37.02$

71.81

26.85

53.28

62.78

78.80

21.80

36.42

44.72

64.19

26.12

48.17

67.83

81.94

22.28

71.18

40.72

73.84

16.34

67.62

28.45

70.62

25.32

31.71

83.43

73.00

25.45

33.52

49.74

59.62 
TABLE 6-4 (Continued)

SUMMARY OF ESTIMATED UNIT COSTS FOR TRANSPORTING SPENT FUEL FROM SPECIFIC REACTOR LOCATIONS TO FIS FACILITIES ${ }^{a}$

(1989 Dollars)

Reactor to Destination

$\frac{\text { From Calvert Cliffs to }}{\text { Eastern U.S. Site }}$

Western U.S. Site

$\frac{\text { From Prairie Is land to }}{\text { Eastern U.S. Site }}$

Western U.S. Site

From Pilgrim to

Eastern U.5. Site

Western U.S. Site

From Indian Point to

Eastern U.S. Site

Western U.S. Site $\frac{\text { Total Cost for Shipment }(\$ / \mathrm{kgU})}{\text { By Truck }}$

$\$ 20.63$

58.64

$\$ 41.07$

76.61

30.27

49.16

40.23

54.15

35.13

57.27

80.56

78.48

31.35

61.93

49.53

76.51

a Based on 0.461 MTU/PWR assembly and 0.183 MTU/BWR assembly, as introduced into the reactor. Unit cost will increase or decrease proportionately to corresponding decreases or increases in the uranium content of the fuet assemblies.

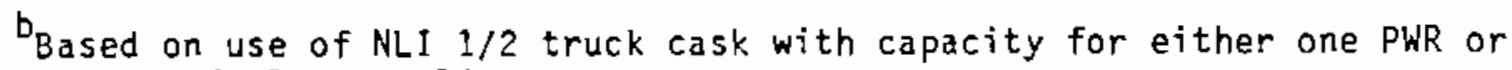
two BWR fuel assembilies.

C Based on use of If -300 rail cask with capacity for either 7 PWR or 18 BWR fuel assemblies. 


\subsection{SENSITIVITY OF FEES TO CHANGES IN CONDITIONS}

The sensitivity of the total fees 6 for FIS to changing conditions of cost, schedule, mix of spent fuel types, and discount rate, and to whether or not the facility was subject to NRC licensing, was determined for the drywell cases at storage capacity levels of 100 MTU and 1900 MTU (see Section 10.0 of Exhibit A). The results of these fee sensitivity studies are summarized below:

(1) A change of \$1-million in the capital cost of transfer facilities at the FIS site causes a corresponding change in the total fees for FIS of about $\$ 12 / \mathrm{kgU}$ at the 100 MTU capacity level, decreasing to about $\$ 1 / \mathrm{kgU}$ at the 1900 MTU capacity level.

(2) A change of $\$ 1,000$ in the cost of canisters or drywells causes a corresponding change in the total fees for FIS of about $\$ 3 / \mathrm{kgU}$ at all capacity levels.

(3) For each year the term of the FIS program is extended (due to delay in repository startup), there is an increase in the total fees for FIS at the 100 MTU capacity level of about $\$ 15 / \mathrm{kgl}$ for instances where a new transfer facility is built, and about $\$ 10 / \mathrm{kgU}$ for instances where an existing transfer facility can be utilized for FIS. These increases amount to about $\$ 1 / \mathrm{kgU}$ at the 1900 MTU capacity level.

(4) For each year the time over which spent fuel is received for storage increases, there is a increase in the total fees for FIS at the 100 MTU capacity level of about $\$ 2 / \mathrm{kgU}$ for instances where a new transfer facility is built, and about $\$ 9 / \mathrm{kgU}$ for instances where an existing transfer facility can be utilized for FIS. There is little impact of the receipt schedule on total fees at the 1900 MTU capacity level.

(5) For each year the time for design, licensing, and construction of the initial FIS facilities decreases (and thereby correspondingly increasing the amount of time spent fuel is stored), there is an increase in the total fees for FIS at the 100 MTU capacity level of about $\$ 20 / \mathrm{kgU}$ for instances where a new transfer facility is built, and about $\$ 12 / \mathrm{kgU}$ for instances where an existing transfer facility can be utilized. These increases amount to about $\$ 2 / \mathrm{kgl}$ in both instances at the 1900 MTU capacity level.

6/The term "total fees" used in this section refers to the sum of the Initial and Final Payments. 
(6) A one kilogram decrease in the average amount of uranium contained in the spent fuel in a drywell from the $42 \mathrm{~g} \mathrm{~kg}$ loading assumed for this study causes an increase in the total fees for FIS by about $\$ 0.20 / \mathrm{kgU}$, in the range of $366 \mathrm{~kg} \mathrm{U}$ to $461 \mathrm{~kg} \mathrm{U}$. Conversely, a one kilogram increase in the average amount of uranium contained in a drywell causes a decrease of $\$ 0.20 / \mathrm{kgU}$ in the total fees for FIS.

(7) An increase in the discount rate by one percentage point causes a decrease in the total fees for FIS at the 100 MTU capacity level of about $\$ 25 / \mathrm{kgU}$ for instances where a new transfer facility is built, and about $\$ 18 / \mathrm{kgU}$ for instances where an existing transfer facility can be utilized for FIS. These decreases amount to about $\$ 5-6 / \mathrm{kgU}$ for cases at the 1900 MTU capacity level.

(8) Not having to follow the procedural (not safety) requirements involved in NRC licensing activities nor conform the FIS systems to NRC security requirements causes a decrease in the total fees for FIS by $\$ 120-130 / \mathrm{kgU}$ at the 100 MTU capacity level decreasing to $\$ 6-8 / \mathrm{kgU}$ at the 1900 MTU capacity level.

\subsection{ESTABLISHMENT OF FEES FOR FIS SERVICES}

JAI recommends that the Oepartment establish its fee for FIS services in the same basic manner as it did in the 1983, 1984, 1985, 1986 and 1987 reports, and which is described below:

(1) The fee should be published in two parts -- an Initial Payment and a Final Payment. The Final Payment should be subdivided into two components: one should include all cost components except transportation of spent fuel, and the other should include spent fuel transportation and associated costs between reactor locations and FIS facilities.

(2) Upon publication, the Initial Payment, and the Final Payment for all cost components except transportation, should be firm until revised by a subsequent publication. The Departinent should plan to invoice the individual user for the actual cost the Department incurs in the transportation of the user's spent fuel to the FIS facilities.

(3) Until the Department has received commitments for FIS services, it should pubiish a fee schedule for a range of capacities from 100 MTU to the 1900 MTU limit established by the Act.

(4) Until the Department determines the location or locations for FIS facilities and the method or methods of storage to be used, the fee that represents the highest $\cos t(s)$ for the combin- 
ation of types of location(s) and storage method(s) under consideration should apply.

(5) Upon execution of the first contract(s) the Department should commence the design of the FIS facilities on the basis of the contractual comitments that then exist for FIS services. These facilities should have the capacity for storage of only that amount of spent fuel which is committed to storage under the then-existing contracts.

(6) These first contract(s) should determine the fee for FIS services from the schedule of fees published in the Federal Register. The Initial payment should be the unit price in effect for the total storage capacity required by such contract(s) or for 100 MTU, whichever is larger. This same Initial Payment should then be charged to all subsequent users of FIS services until the Initial Payment is next revised.

(7) The Department should revise its fee (both the Initial and Final Payment) annually to reflect (among other things) the economies of a larger FIS operation which results from additional commitments for FIS services.

(8) Upon completion of the preoperational activities (i.e., design, safety reviews, construction, and associated activities), the Department should determine the total costs incurred -- and should credit or debit the Final Payment of each user with the difference between the amounts paid as Initial payments and its pro rata share of the total preoperational costs (net of its pro rata share of interest earned on advance payments made).

(9) After decomissioning of the FIS system, or December 31, 2006, whichever is later, the Department should determine the total costs incurred in design, construction, operation and decommissioning of the FIS system through December 31, 2006 -and should make final adjustments to the extent that there is a difference between the amounts paid by each user in Initial and Final Payments and the user's pro rata share of the aforementioned costs (net of its pro rata share of interest earned on advance payments made).

The Department should plan to sign contracts for FIS services with users within 60 days after the user's need has been certified by NRC. This is necessary in order for the Department to be able to provide the required storage facilities on a timely basis. 
. 


\subsection{SPENT FUEL ACCEPTANCE CRITERIA FOR FIS}

In developing revised spent fuel acceptance criteria, JAI continued to be mindful of the facts that FIS was intended for use only in special situations and that only a limited amount of spent fuel would be eligible for FIS. This is in marked contrast to the repository program, which can be expected to receive all spent fuel for disposal purposes, absent any reprocessing in the U.S. Therefore, in order to simplify the FIS program and minimize the costs attendant therewith, it was concluded that the interests of the prospective users of FIS services were best served by the Department accepting only non-defective fuel assemblies and canistered consolidated fuel rods meeting specific and clearly defined acceptance criteria.

JAI has reviewed the spent fuel acceptance criteria which was included in the 1984 report and has found no basis to make any further changes thereto at the present time. For the convenience of the reader, the acceptance criteria contained in the 1984, 1985, 1986 and 1987 reports has been included in Exhibit $C$ to this report. 

EXHIBIT A

DESIGN DESCRIPTION AND ESTIMATED COSTS FOR THE DRY STORAGE

OF SPENT NUCLEAR FUEL IN FEDERAL INTERIM STORAGE FACILITIES 
EXHIBIT A

TABLE OF CONTENTS

Page

1.0 SPENT FUEL CANISTERS A $1-1$

1.1 Description Al-2

1.2 Estimated Cost A1-2

2.0 RECEIVING AND HANDLING FACILITIES A2-1

2.1 Facilities for Receiving and Transfer A2-1

2.2 Facilities for Receiving, Canning and Transfer A2-7

2.3 Modification of Existing Facilities A2-8

$\begin{array}{ll}2.4 & \text { Estimated Costs A2-10 }\end{array}$

3.0 STORAGE CASKS A3-1

3.1 Description A3-1

3.2 Estimated Cost A3-1

4.0 DRYWELLS A4-1

4.1 Description A4-1

4.2 Estimated Cost A4-1

5.0 CONCRETE SILOS A5-1

5.1 Description A5-1

5.2 Estimated Cost A5-1

6.0 STORAGE FACILITY COSTS A6-1

6.1 Cask Storage Facilities A6-1

6.2 Drywell Storage Facilities. A6-2

6.3 Silo Storage Facilities A6-3

6.4 Estimated Costs A6-4

7.0 OPERATING COSTS FOR FIS SYSTEM A7-1

7.1 Loading, Storage and Removal A7-1

7.2 Decontamination and Decommissioning A7-4

8.0 OTHER ASSDCIATED STORAGE COSTS A8-1

8.1 Government Administrative Costs AB-1

8.2 FIS Development Costs A8-1

8.3 Impact Aid A8-2

9.0 TOTAL COST OF FIS STDRAGE A9-1

10.0 SENSITIVITY OF COSTS TD CHANGES IN CONDITIONS A10-1

10.1 Impact of Cost Changes Al0-1

10.2 Impact of Schedule Changes A10-10

10.3 Impact of Mix of Spent Fuel Types A10-23

$\begin{array}{ll}10.4 & \text { Impact of Discount Rate A10-28 }\end{array}$

10.5 Impact of NRC Licensing Status A10-33 


\section{EXHIBIT A}

DESIGN DESCRIPTION AND ESTIMATED CDSTS FDR THE DRY STORAGE

OF SPENT NUCLEAR FUEL IN FEDERAL INTERIM STORAGE FACILITIES

This Exhibit describes the design of the components of the alternative FIS systems considered, including (i) canisters, (ii) required new facilities for the transfer of spent fuel from shipping casks to either transfer casks or storage modules and for performing the encapsulation of spent fuel in cases where such is considered necessary, (iii) modifications to existing facilities at government sites which are necessary to perform the same operations as described in (ii) above, (iv) storage modules, and (v) storage facilities. The results of estimates of the capital cost of the components of the alternative FIS systems are presented as are the cost of operation thereof, and the special costs stipulated by the Act to be included in the development of charges for FIS services. A summary of the total and discounted costs of operation of the FIS system, and the unit costs resulting therefrom, is presented for each combination of storage method, capacity, and facility location which was considered (as described in Section 3.0 of the report).

In addition to the foregoing, sensitivity analyses were performed to determine the effects of changing conditions of cost, schedule, mix of fuel type, discount rate, and licensing-related activities on the unit cost for FIS.

$1.0 \quad$ SPENT FUEL CANISTERS

JAI considered both the need for canistering spent reactor fuel assemblies and the type of canister that should be employed. It was concluded that spent fuel assemblies that were destined for storage in sealed drywells or silos should be encapsulated to provide a double containment for the fuel assemblies. Since the metal storage casks are designed with a double containment lid, no canistering of the fuel assemblies was considered necessary for this mode of storage. It was also concluded that a carbon steel canister with convex ends would perform satisfactority in the dry storage environment. 


\section{$1.1 \quad$ DESCRIPTION}

The canister designed to contain one PWR or two BWR fuel assemblies has a 13-in. inside diameter and a 1/2-in. wall thickness. Canisters are prefabricated from 1/2-in. thick steel plate with a convex bottom and lid. The guide cages used to position the fuel within the canister are fabricated from 1/8-in. steel plate with 1/4-in. steel plate cage guides. A I/2-in. steel plate is located at the bottom of the canister to support the cage and fuel. The mating surfaces of the lid and wall are machined for welding. Guides are welded inside the lid to assure positive alignment and to facilitate guiding the lid into place. A grapple pintle on the top of the lid is used to lift the lid and place it on the canister; it is also used to apply pressure during welding to assure positive contact, and to lift the loaded canisters. A vent hole through the pintle and lid is provided to relieve any pressure build-up during girth-welding, and to permit pressure and leak testing of the loaded canister; it is seal welded upon completion of such testing. It can also be used to add an inert atmosphere to the canister if desired for heat transfer or for additional corrosion protection. A TIG or MIG weld of the girth and the pintle seal welds is used to eliminate the need for a flux and subsequent chipping of slag, and the attendant generation of scrap.

Empty canisters and lids are moved from storage into the hot cell

and lifted using a magnetic grapple. The empty canisters are stored in special racks and the lids are placed on a conveyor that feeds the welding machine. The loaded and tested canisters are placed in interim storage in a small vault in new hot cell facilities or are stored in a shielded storage cask in existing hot cell facilities. The canisters are subsequently loaded into a transfer cask for transfer to drywell storage or are loaded directiy into a concrete silo.

\subsection{ESTIMATED COST}

The cost of canisters for PWR and BWR fuel assemblies to be stored in drywells or silos was estimated to average $\$ 4,985$ (1989 dollars). 


\subsection{RECEIVING AND HANDLING FACILITIES}

Three types of receiving and handling facilities were considered for the FIS facilities. At government facilities which have no hot cell facilities which can be used for the transfer of spent fuel from shipping casks into storage casks, such will have to be provided. In the case of drywell or silo storage, these transfer facilities will also have to be equipped for encapsulation of the fuel assemblies. (Encapsulation is not necessary for cask storage because the cask provides the desired double containment of the spent fuel.) Both the transfer-only and transfer/encapsulation facilities should be equipped with a limited amount of lag storage space.

At government facilities which have hot cell facilities which could be used for the above described purposes, some modifications and equipment additions are assumed to be necessary in order to perform the described activities.

This section describes the conceptual designs of the new transfer and transfer/encapsulation facilities, and the required additions and modifications to an existing one -- and provides an estimate of the capital costs associated with such facilities.

\subsection{FACILITIES FOR RECEIVING AND TRANSFER}

A basic design for a transfer facility was developed and is shown in Figures A2-1, A2-2 and A2-3. This facility is a simple hot-cell facility equipped with standard hot cell equipment, and is designed to accomplish the following operations:

(1) receive, inspect and washdown and/or decontaminate the shipping casks and storage casks

(2) remove the cask heads from the casks and temporarily store them

(3) remove the spent fuel from the shipping cask and place it in the storage cask

(4) place the cask head on the storage cask when loaded, seal, and transfer the cask to the storage area

(5) place the cask head on the empty shipping cask and prepare cask for return shipment 


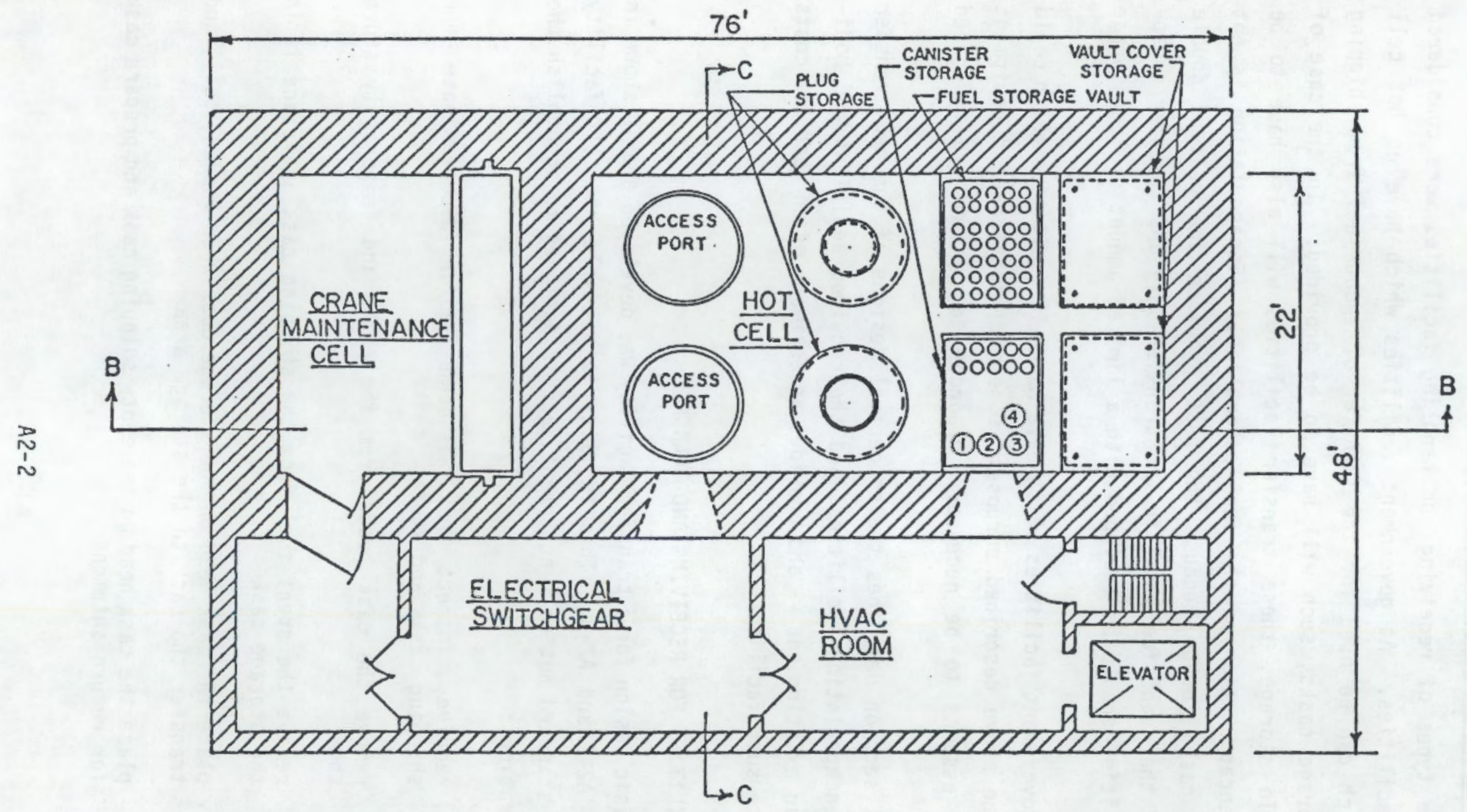

FIGURE A2-1

PLAN VIEW OF TRANSFER FACILITY

Section View AA

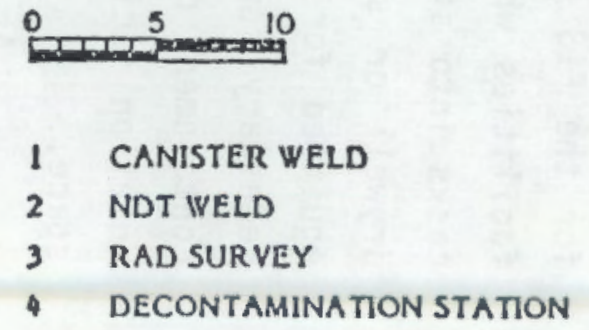




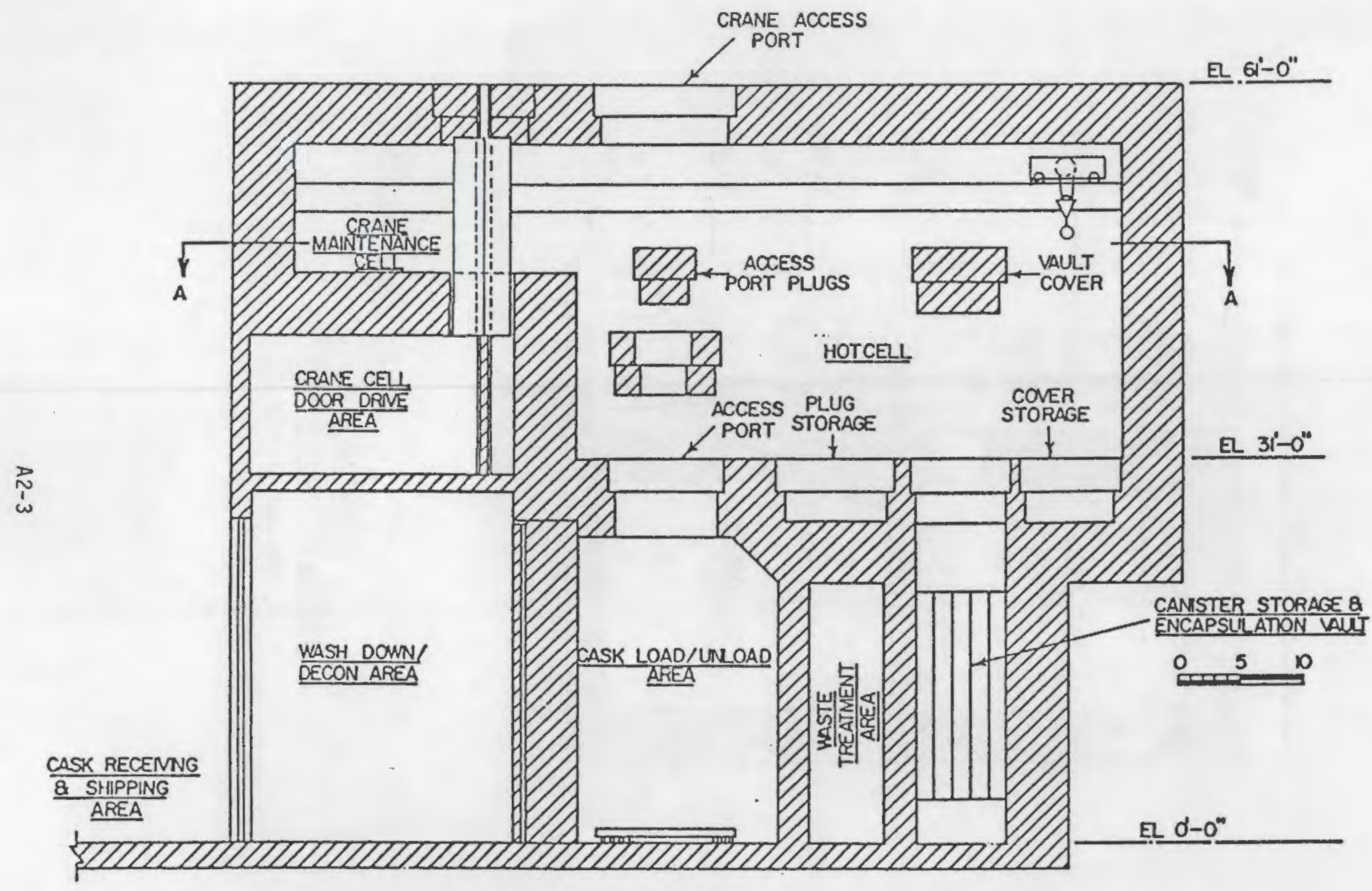

FIGURE A2-2

SIOE VIEN OF TRANSFER FACILITY

Section View $B B$ 


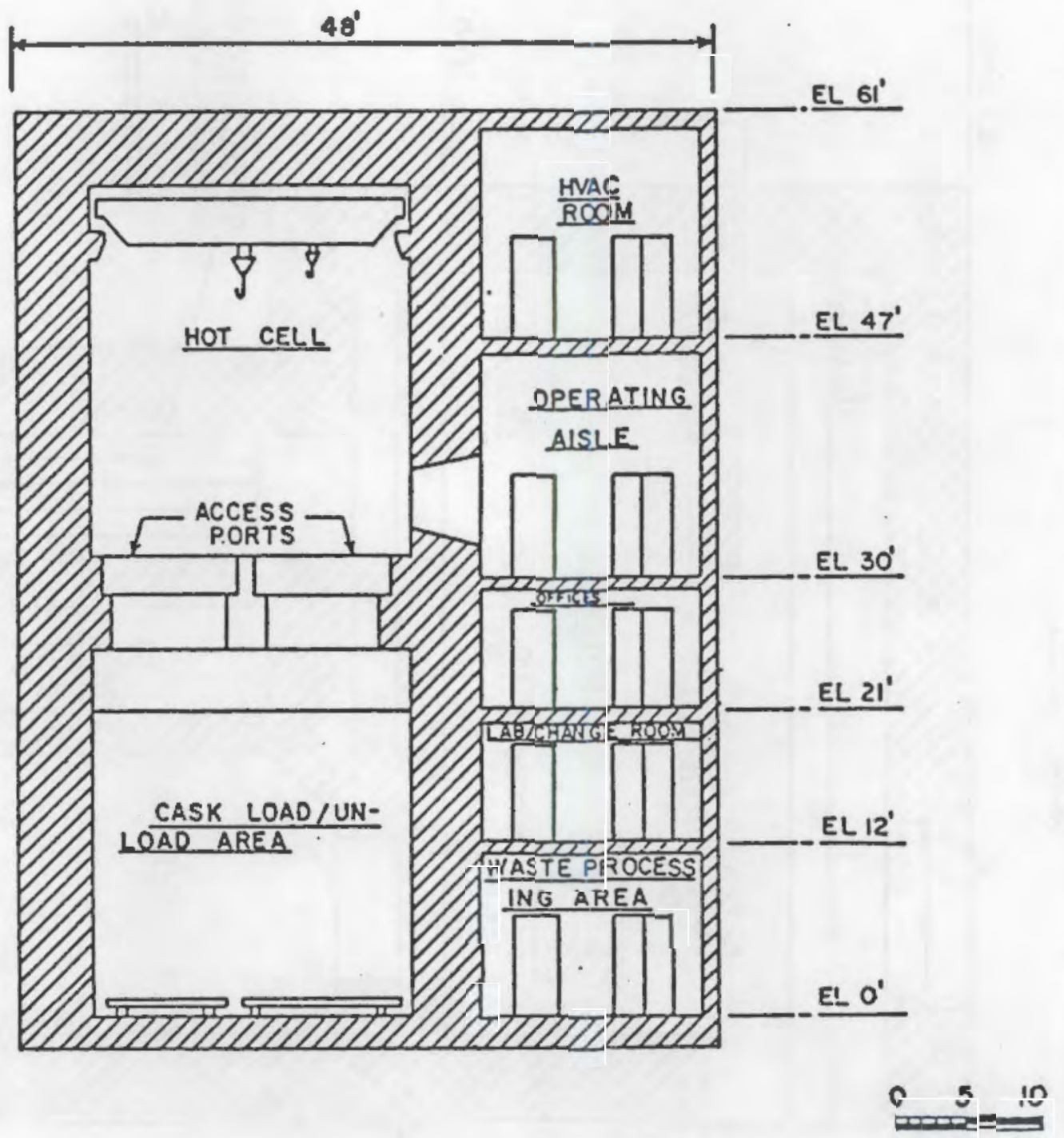

FIGURE A2-3

END VIEW OF TRANSFER FACILITY

Section View CC 
(6) provide a small amount of lag storage in the hot cell to minimize shipping cask turnaround time, and for general operational convenience.

It is recognized that there have been a number of unique conceptual designs developed for accomplishing these types of transfer operations at low estimated capital cost. However, the development of these designs has not proceeded to the point that the Department should risk the use of them from either a cost or licensing standpoint, in the establishing of charges for FIS services at the present time.

Spent fuel shipping casks are received at the FIS facility on special rail cars for the IF-300 cask and on tractor-trailer trucks for the NLI $1 / 2$ cask. The rail transport vehicle is spotted on a rail siding, extending into the concrete pad in front of the FIS transfer facility; the trucks are also spotted on this same pad. The mobile transporter straddles the rail car or truck and engages the trunions of the cask after the personnel barriers, tie-downs and impact limiters are removed. The casks are lifted horizontally to clear the carrier vehicle and moved to a clear space on the concrete pad. The casks are then rotated to a vertical position using a small hoist. They are then positioned over the dolly and lowered onto it. Tiedowns to attach the cask to the dolly are secured and the trunions disengaged. The mobile transporter is moved into the clear to be available for other work including transport of storage casks, transfer casks or silos to the storage area. The dolly and cask is moved into the washdown/decontamination area for final inspection, removal of the outer head and inner head bolts, attachment of the inner head lifting sling and installation of the expandable seal ring, gasket protection, and contamination bib. The dolly and cask are then ready to be moved into the air lock (cask unloading) area.

The transfer facility described in Figures $A 2-1, A 2-2$ and $A 2-3$ is a reinforced concrete structure having overall dimensions of $48 \mathrm{ft}$. $x 76 \mathrm{ft}$. by $61 \mathrm{ft}$. high. The interior of the hot cell is $22 \mathrm{ft}$. wide, $45 \mathrm{ft}$. long and 25 $\mathrm{ft}$. high and contains a 40-ton bridge crane with a 10-ton auxiliary hoist on the same trolley. A clearance of $18 \mathrm{ft}$. under the crane hooks is provided for handling grapples and fuel assemblies. The crane is equipped with an inching motor for precise movement as well as an emergency drive to move the crane into the $22 \mathrm{ft} . \times 13 \mathrm{ft}$. shielded maintenance cell at one end of the hot cell. 
All shielding walls are constructed of 5- $\mathrm{ft}$. thick nuclear grade concrete and are lined with stainless steel plate for ease of decontamination. A 5-ft. thick concrete door can be used to shield the crane maintenance cell from the hot cell in the event spent fuel is exposed in the hot cell and a crane breakdown occurs. Cell viewing is provided through two 4-ft. square, leadglass windows and CCTV cameras on the crane and in the cell. A master slave, heavy duty manipulator at each view-window is available for special purposes.

Lag storage is available in two small vaults below the floor level of the hot cell, each with space for 35-40 baskets in safe geometry spacing. Each vault has a $5-\mathrm{ft}$. thick concrete cover to be used in the event the hot cell needs to be entered when spent fuel is in lag storage. Each such vaut is $7 \mathrm{ft}$. wide, $10 \mathrm{ft}$. Jong and $31 \mathrm{ft}$. deep (see Figure A2-2). Cooling is provided by drawing cell ventilation air through the fuel assemblies into a plenum in the lower part of each vault. The air is filtered and cooled in the HVAC area.

The cask loading/unloading area is an air-lock $22 \mathrm{ft}$. wide and $21 \mathrm{ft}$. long where both the shipping casks and storage casks are brought in on dollies and raised to mate with the underside of the hot cell access port for unloading and loading. An expandable seal between the top of the cask and the access port prevents cell atmosphere leakage into the air-lock area.

The two cell plugs which fill the access port between the air-iock and the hot cell are each constructed with a ring and a center plug such that they can be removed either together or individualiy. Only the center plug is removed when a truck cask is to be unloaded while both the plug and ring are removed for rail casks and storage casks. Special storage holes are provided in the floor of the hot cell for the cell plugs when they are removed in order to permit top surfaces of the plugs to be flush with the hot-cell floor, eliminating the need for additional head room in the celt (see Figure A2-2).

The auxiliary area is a multi-storied building with the HVAC and electrical switch gear equipment located on the top floor (see Figures A2-1 and $A 2-3)$. The second floor is used as an operating aisle and a manipulator repair shop. The bottom floor is utilized for low-level liquid and solid waste handling and processing, including catch tanks for the hot cell and decontamination areas, liquid filter and ion exchange systems, liquid waste solidification equipment and solid waste compaction equipment. 
The other floors of the auxiliary area are utilized for change room facilities, health physics analytical laboratory, general plant maintenance shop, and administrative and engineering offices.

\subsection{FACILITIES FOR RECEIVING, CANNING AND TRANSFER}

The same basic facilities that were described for the transfer of spent fuel from shipping casks to storage casks in Section 2.1 can be used for the receipt, canning and transfer of the canned spent fuel assembiies to either silos or a transfer cask (in the cask of drywell storage). However, in the latter cases, the facilities are equipped to perform the following additional activities:

(1) load spent fuel assemblies into canisters

(2) weld lid onto canister

(3) backfill canister and seal

(4) test/inspect weld integrity, and

(5) decontaminate loaded canisters.

In these cases one of the two $7 \mathrm{ft}$. by $10 \mathrm{ft}$. by $31 \mathrm{ft}$. deep vaults shown in Figure A2-1 is utilized for new canister storage, loaded canister storage and the welding and test equipment. A special weiding jig accurately positions the canisters against guide and drive rollers. New canisters and lids are moved into the cell through the air-lock to the cell port and to the weld jig or lag storage by means of an electromagnetic grapple. After the fuel assemblies are loaded into the canister, a handling tool picks up a iid from a conveyor and places it on the canister, holding it in place during welding. The TIG welder is positioned using a roller-follower to maintain weld gap distance. The canister is rotated and the welding sequence carried out. A canister grapple lifts the canister to the test jigs for weld and leak tests and radiation survey test.

Also for these cases, a part of the first floor of the auxiliary area is used as a warehouse to store the new canisters. Part of the second floor is eliminated to provide a high-bay warehouse so the canisters can be stored verticaliy. A small jib crane in this area with a magnetic grapple is 
used to transfer the canisters to a handling cart for movement to the air-lock and into the cell. An $18 \mathrm{ft}$. high, double door provides access to this warehouse area.

\subsection{MODIFICATION OF EXISTING FACILITIES}

For the purposes of determining the likely cost of dry storage of spent fuel in FIS facilities at a government site which has an existing hot cell it was assumed that all of the activities described in Sections 2.1 and 2.2 could be performed in the hot cell with certain additions and modifications. It was also assumed that other existing facilities were available to washdown incoming casks to remove road dirt prior to unloading in the hot cell.

The hot cell was assumed to be $50 \mathrm{ft}$. wide, $160 \mathrm{ft}$. long and $55 \mathrm{ft}$. high. It is equipped with a 150/15-ton crane (15-ton auxiliary hoist on same trolley) with a hook height of $50 \mathrm{ft}$. It has a bridge mounted, overhead heavy duty manipulator with an elbow capacity of 5000 pounds, a manipulator capacity of 600 pounds, and a hook height of $28 \mathrm{ft}$. In addition the cell is equipped with two wall-mounted manipulators with a $28 \mathrm{ft}$. reach and a $27 \mathrm{ft}$. hook height. The cell is shielded with 7-ft. thick, reinforced concrete and has lead-glass viewing windows at two operating elevations on both sides of the cell length. The manipulators could be used in the welding operation but the hook height is insufficient for lifting spent fuel or loaded canisters to or from casks. The hot cell is supported by HVAC equipment, radiation alarms, jaboratories for checking activity levels of smear samples, and radwaste processing facilities to handle decontamination solutions.

Any existing special test equipment in the hot cell would need to be removed or stored out of the way and the hot cell totally dedicated to the receiving, canning, and/or transfer of spent reactor fuel during the period that fuel is received for storage, and when it is being removed from storage. The modifications assumed to be required include the following:

(1) installation of CCTV on the cranes, overhead manipulators and in the cell to provide close-up viewing of operations

(2) construction of cask support structures in the cell to prevent the casks from falling from the vertical position during operations 
(3) procurement and installation of a modified metal storage cask for lag storage of loaded canisters prior to their placement in drywells or silos, and of two standard storage casks for lag storage of spent fuel unloaded from shipping casks (since radioactive material contained in the cell will need to be enclosed in shielded containers prior to introducing or removing items from the cell)

(4) construction of racks for all cask heads including those from storage casks that will need to be used for lag storage

(5) installation of welding and testing equipment described in Section 2.2 for the canistering of spent fuel assemblies

(6) installation of a conveyor for canister lids and a rack for new canisters.

It was assumed the cell cranes and manipulators are usable without modification.

The handling procedure at the existing hot cell was assumed to differ from a new FIS transfer facility. The vehicles (trucks) bringing the casks to the existing hot cell are assumed to move directly into and out of the cell through shielded, air-lock doors. The cask tie-downs, personnel barriers, and impact limiters are removed. The trunions are engaged with a yoke using the 150-ton bridge crane. The cask is lifted clear of the vehicle and rotated to a vertical position. It is then moved to a special cask holder where it is locked in place to prevent tipping during unloading or from any seismic activity. This holder also serves as a scaffold for worker access to the top of the cask to remove head bolts and attach head lifting slings. The outer head is removed and stored and the inner head bolts removed. Metal storage casks are placed in similar cask holders with their inner heads in place to shield any fuel assemblies transferred previously. The operators vacate the cell and the cell door is closed so that remote unloading can be conducted. The inner heads of the transport and storage casks are removed and the fuel is transferred from the shipping cask to the storage cask. Where fuel is to be sealed in canisters, three metal storage casks are used for surge storage; one for PWR fuel, one for BWR fuel and one for canistered assemblies. When canisters are to be moved to silos or drywells, a mobile transporter is used to bring the silo or transfer cask into the cell for loading. 
It was also assumed for the purposes of this study that a separate storage area would be provided for the storage of modules at a government site having existing transfer facilities.

\subsection{ESTIMATED COSTS}

Estimates were made of the capital costs of new transfer and encapsulation facilities required for the FIS of spent fuel at a government site having no such facilities. A summary of these estimated costs is set forth in Table A2-1 for each of the three methods of dry storage considered.

\section{TABLE A2-1}

ESTIMATED CAPITAL COSTS OF NEW TRANSFER AND ENCAPSULATION FACILITIES

$$
(\$ 000,1989)
$$

Site Preparation

Structures

Equipment

Equipment Installation

(35\% of equipment cost)

Engineering (15\%)

Licensing

Contingency (35\%)

Total
Capital Costs

\begin{tabular}{|c|c|c|}
\hline $\begin{array}{c}\text { Storage } \\
\text { Cask } \\
\end{array}$ & Drywell & Silo \\
\hline$\$ \quad 13$ & $\$ \quad 13$ & 13 \\
\hline 7,444 & 7,444 & 7,444 \\
\hline 3,837 & 4,648 & 4,652 \\
\hline 1,343 & 1,627 & 1,628 \\
\hline 12,637 & 13,732 & 13,737 \\
\hline 1,896 & 2,060 & 2,061 \\
\hline 924 & 924 & 924 \\
\hline 15,457 & 16,716 & 16,722 \\
\hline 5,410 & 5,851 & 5,853 \\
\hline$\$ 20,867$ & $\$ 22,567$ & $\$ 22,575$ \\
\hline
\end{tabular}


Estimates were also made of the cost of additions and modifications to the existing hot cell which are required to transfer and encapsulate spent fuel. A summary of these estimated costs is set forth in Table A2-2 for each of the three methods of dry storage considered.

\section{TABLE A2-2}

ESTIMATED COSTS OF ADDITIDNS AND MODIFICATIONS TO AN EXISTING HOT CELL FOR TRANSFER AND ENCAPSULATION OF SPENT FUEL $(\$ 000,1989)$

Equipment

Equipment Installation

(35\% of equipment cost)

Engineering (15\%)

Safety Review

Contingency (35\%)

Tota]
Capital Costs

\begin{tabular}{lll}
\hline $\begin{array}{c}\text { Storage } \\
\text { Cask }\end{array}$ & Drywell & Silo \\
$\$ 979$ & $\$ 4,919$ & $\$ 4,922$
\end{tabular}

\begin{tabular}{|c|c|c|}
\hline 343 & $512^{\mathrm{a}}$ & $513^{\mathrm{a}}$ \\
\hline 1,322 & 5,431 & 5,435 \\
\hline 198 & 815 & 815 \\
\hline 422 & 422 & 422 \\
\hline 1,942 & 6,668 & 6,672 \\
\hline 680 & 2,334 & 2,335 \\
\hline
\end{tabular}

$\$ 2,622 \quad \$ 9,002 \quad \$ 9,007$

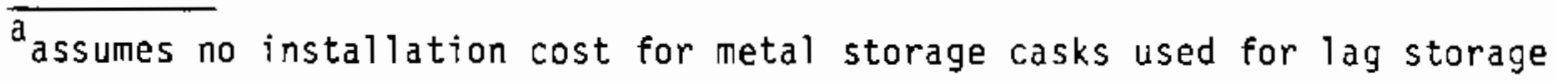




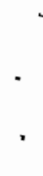




\section{$3.0 \quad$ STORAGE CASKS}

\subsection{OESCRIPTION}

The use of metal storage casks, which may or may not be licensed for transportation over the road, for the storage of spent fuel offer an attractive option in common with the drywell and silo modes, in that it permits the addition of storage capacity in small increments as increased capacity is required. The casks offer an additional advantage of providing capability for on-site transportation of spent fuel with the possible future prospect of serving as off-site shipping containers.

At the present time, several cask manufactures have metal storage cask designs; Ridihalgh, Eggers and Associates, Inc. (the REA-2023 cask) Transnuclear, Inc. (the TN-24 cask), GNS (the CASTOR-V cask), Nuclear Assurance Corporation, Westinghouse, and Combustion Engineering. For this study, the Transnuclear, Inc. TN-24 cask was selected, as it represents the capacity and cost typical of these large storage casks. The TN-24 cask is shown in Figure A3-1. The cask weight (loaded) is 100 U.S. tons; it is $16 \frac{1}{2}$ $\mathrm{ft}$. in length and $8 \mathrm{ft}$. in diameter. It will store either 24 PWR or 52 BWR fuel assemblies. According to design data, the cask will limit the fuel clad temperature to $375^{\circ} \mathrm{C}$, at a decay heat of $1.0 \mathrm{~kW} / \mathrm{PWR}$ assembly (24 kW total).

It is assumed that each cask can be procured with a mounting skid that can be moved with the cask onto a storage area pad, el iminating the need for special cradles.

\subsection{ESTIMATED COST}

Based upon manufacturers estimates and assuming delivery to a Western U.S. site, the 1989 cost of the metal storage cask was estimated to be $\$ 1,070$-thousand.

\footnotetext{
*This cask design is now owned by Mitsubishi.
} 


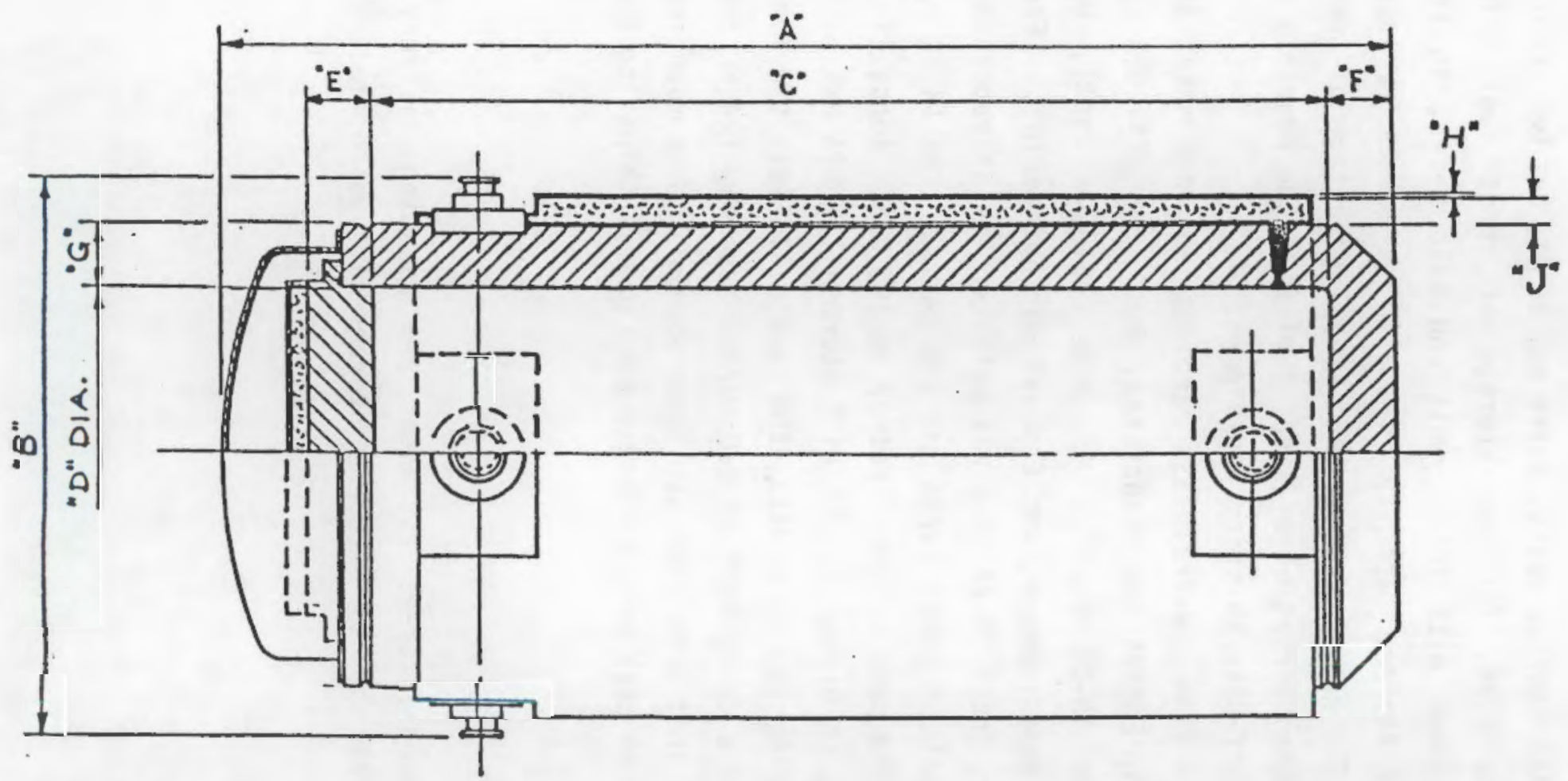

A. Length $5030 \mathrm{~mm}$

B. Diameter $2400 \mathrm{~mm}$

C. Cavity Length $4140 \mathrm{~mm}$
D. Cavity Diameter $1460 \mathrm{~mm}$

E. Lid Thickness $270 \mathrm{~mm}$

F. Bottom Thickness $260 \mathrm{~mm}$
G. Wall Thickness $240 \mathrm{~mm}$

H. Shell Thickness $20 \mathrm{~mm}$

J. Shield Thickness $140 \mathrm{~mm}$

\section{FIGURE A3-1}

TN-24 CASK FOR SPENT FUEL STORAGE 


\subsection{DRYWELLS \\ 4.1 DESCRIPTION}

Storage of spent fuel in drywells just below grade is an alternative method of interim storage. The drywells are placed on a grid within a fenced storage area. Each drywell, when loaded and the liner welded closed, provides a sealed, secondary containment for canistered spent fuel assemblies.

A schematic drawing of the drywell design used in this study is set forth in Figure A4-1. The drywell liner consists of a schedule 40 steel pipe which is $16 \mathrm{ft}, 6 \mathrm{in}$. long and has an outside diameter of $16 \mathrm{in}$. A 1/2-in. thick plate is welded into the base of the pipe to form the bottom of the liner. A 1/2-in. thick transition ring is welded to the top of the 16 in. liner. The base of a concentric $5 \mathrm{ft}$. long, schedule 40 steel pipe, with a 20in. outside diameter is then welded to the transition ring. The top of the 20-in. diameter pipe is machined to permit a seal plate of $1 / 2-i n$. thick steel to be inserted in a recess for welding. The transition ring provides a ledge to support the 48-in. long concrete shield plug. The liner is surrounded by 3 in. of grout on the sides and an 8-in. grout plug underneath. A 5-ft. diameter concrete collar, 20 in. thick surrounds the top of the liner and is tapered to $2 \mathrm{in}$. above grade level at the drywell liner to assure positive drainage of any surface water. A 1/2-in. thick steel cover is welded to the top of the liner after a canister of fuel is loaded therein and the concrete plug is in place. Each drywell will contain one canister of spent fuel. The top of the active fuel rods is $8-10 \mathrm{ft}$. below grade level with the canister in place. The surrounding earth serves as a radiation barrier as well as conductor of heat from the drywell.

\subsection{ESTIMATED COST}

The cost of the drywells described in Section 4.1 was estimated to be $\$ 22,617$ (1989 dollars). Therefore, the total cost of the drywell assembly, including the canisters described in Section 1.0 , is estimated to be $\$ 27,602$. 

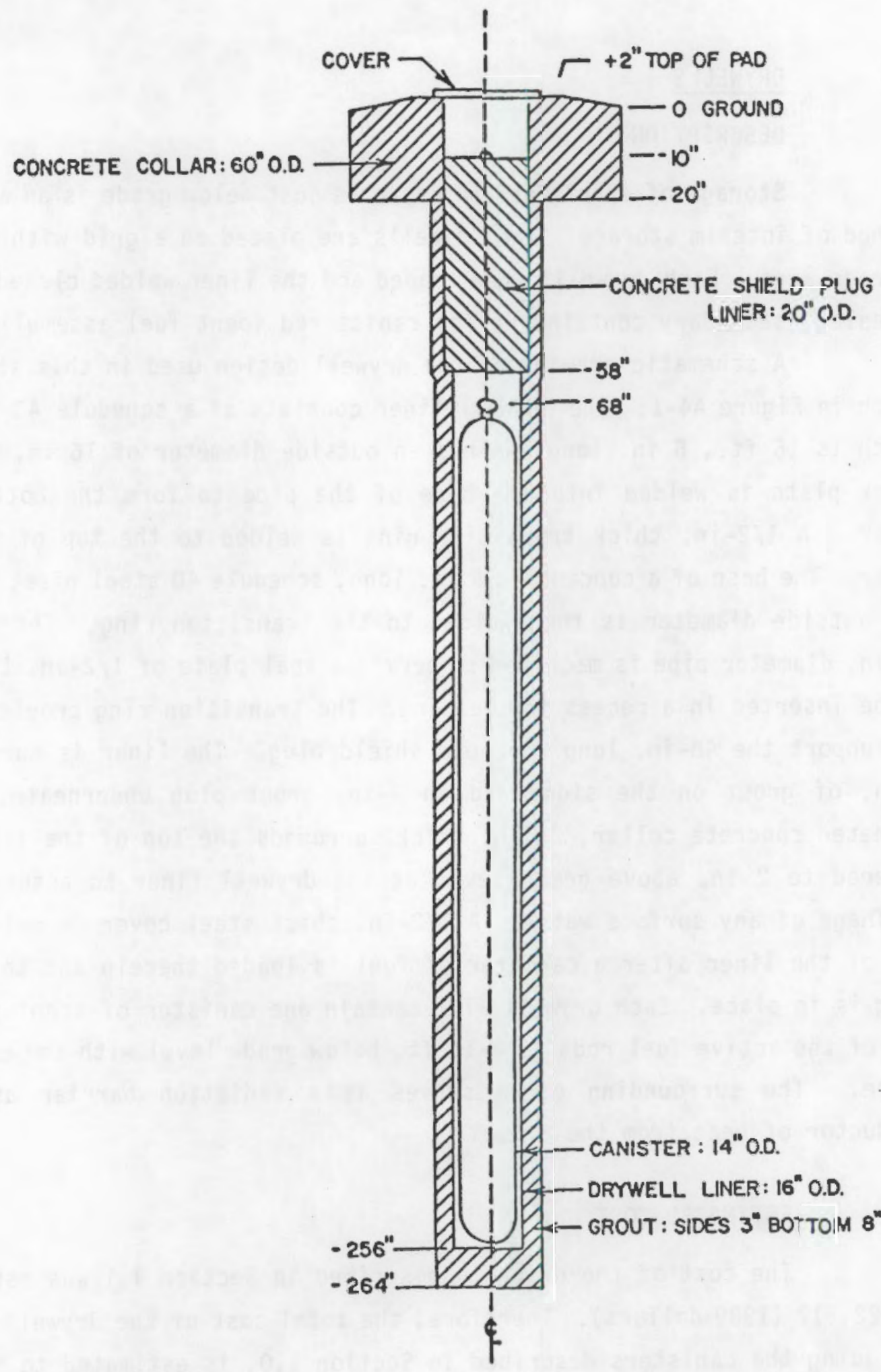

FIGURE A4-1

SCHEMATIC DIAGRAM OF DRYWELL 


\section{$5.0 \quad$ CONCRETE SILOS}

\section{$5.1 \quad$ DESCRIPTION}

Another alternative is the storage of spent fuel in concrete silos above ground. The silos are placed in rows on concrete stands within a fenced storage area. Each silo, when loaded and the liner welded closed, provides a sealed secondary containment for canistered spent fuel assemblies.

A schematic drawing of the silo design developed in this study is shown in Figure A5-1. A silo is a reinforced concrete structure $10 \mathrm{ft}$. in diameter and $23 \mathrm{ft}$. high. It has an inside cavity which is $45 \mathrm{in}$. in diameter and is lined with 1/4-in. steel that also serves as an inside form for pouring the structure. A 2-ft. high pedestal is located in the center of the cavity to support a secondary containment liner. This liner is $36 \mathrm{in}$. in diameter (outside) and has a 1/2-in. wall thickness. The bottom segment of the liner is $17 \mathrm{ft}$. long; at the top it is welded to the upper segment which is $39-i n$. diameter (inside) and $3 \mathrm{ft}$. long. The upper segment of the liner passes through the upper cavity of the silo structure and receives a 4-ft. long concrete plug to effect the closure of the liner cavity. After loading of the silo with canisters of spent fuel and insertion of the plug in the upper segment of the liner, a steel lid is welded on the top of the upper liner cavity to effect the double containment of the fuel. A cruciform spacer is provided for the lower liner cavity to position the canisters of spent fuel contained within. Each silo is capable of storing 4 canisters of spent fuel (4 PWR assemblies or 8 BWR assemblies). The loaded silo weighs about 125 tons.

\subsection{ESTIMATED COST}

The cost of the silos described in Section 5.1 was estimated to be $\$ 107,293$ (1989 dollars). Therefore, the total cost of the silo assembly, including four of the canisters described in Section 1.0, is estimated to be $\$ 127,233$. 

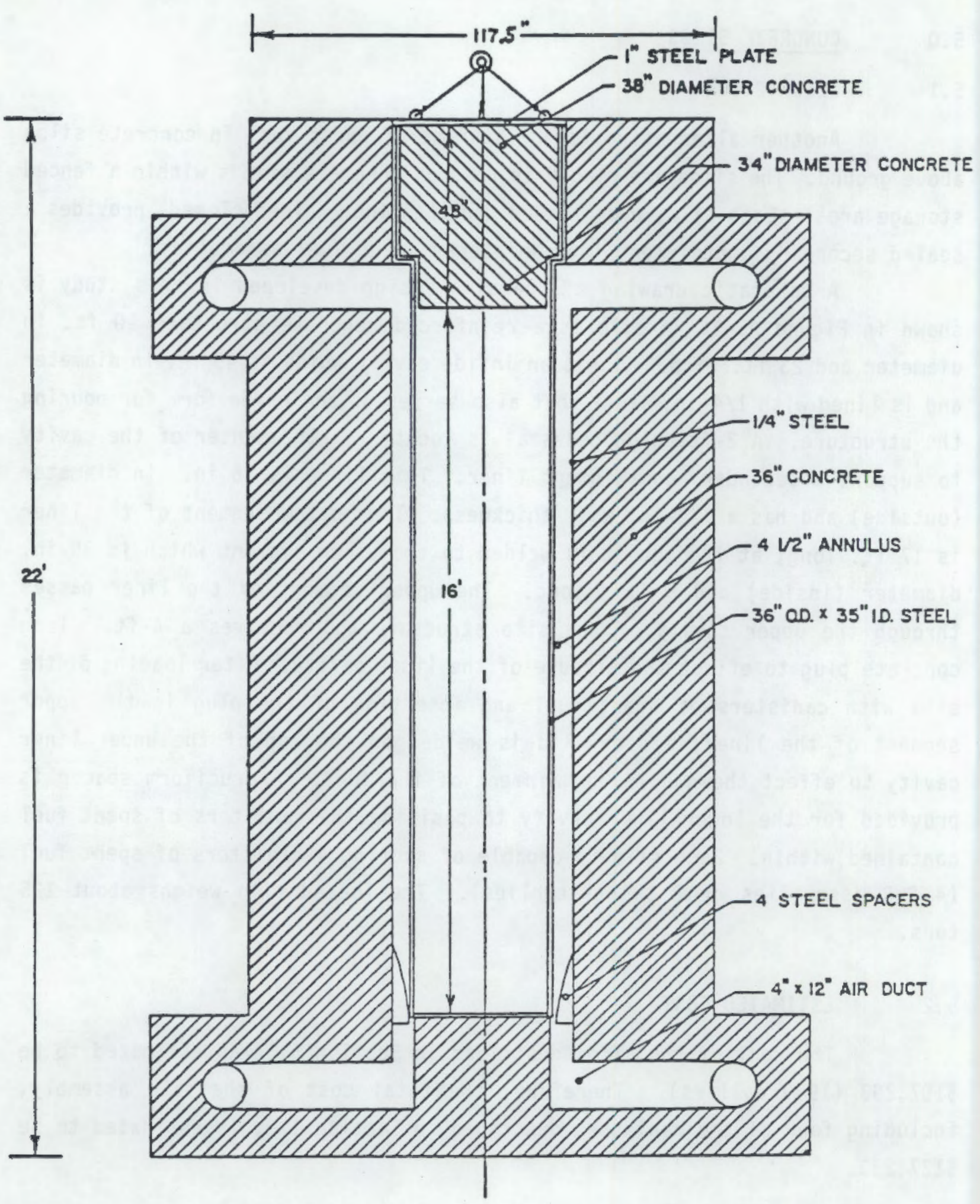

FIGURE A5-1

CONCRETE STORAGE SILO 


\subsection{STORAGE FACILITY COSTS}

\subsection{CASK STORAGE FACILITIES}

The storage of spent fuel in storage casks requires a storage area with concrete stands to support the casks and a transporter to move the loaded cask to the storage area. Storage stands are added as required.

The storage cask area is a graded area with concrete stands $10 \mathrm{ft}$. wide and $18 \mathrm{ft}$. long made of $18-i n$. thick reinforced concrete and includes a $300 \mathrm{ft}$. long and $30 \mathrm{ft}$. wide paved road between the transfer facility and the storage area. Casks are brought to the storage area by a transporter. The casks, on their skids, are placed end-to-end in two parallel rows on the concrete stands which are separated $10 \mathrm{ft}$. apart. On each side of each pair of rows is a $30 \mathrm{ft}$. access driveway to permit easy access to each cask in its storage location. A $50 \mathrm{ft}$. buffer zone is provided around the perimeter of the concrete pad and is surrounded by an $8 \mathrm{ft}$, high chain link security fence topped with 3 strands of barbed wire. The bottom of the fence is anchored in concrete. A microwave security system is used to monitor the perimeter of the storage area, and the area is lighted. A security gate permits access of the transporter and inspection personnel to the storage area.

The transporter used to move the storage casks from the transfer facility to the storage area consists of a commercially available straddle crane having a 150-ton $1 \mathrm{ift}$ capacity, which is modified by the addition of a strongback and yoke. The cask is first lifted from the receiving carrier in a horizontal position and rotated to the vertical. After loading the cask with spent fuel and sealing the heads, it is 1 ifted by the transporter, rotated to horizontal, and placed on its skid. After securing the cask to its skid, the cask/skid unit is lifted and moved to the storage area. When fully loaded, the speed of the transporter is limited to 60-100 ft. per minute. The straddle crane is mounted on dual rubber tires on all four corners and is driven by a diesel engine. It can operate on both gravel and paved roads, and can negotiate grades up to $6 \%$. It has the capability of making a $90^{\circ}$ turn. The wheel base, tread width and clear height are easily modified from standard equipment sizes by removing or adding structural sections to customize the unit to handle the storage casks. 


\subsection{DRYWELL STORAGE FACILITIES}

The storage of canistered spent fuel in drywells requires a storage area, drywells, and handling equipment to transfer canisters to the drywells. This equipment includes a top loading/bottom discharge transfer cask, a plug cask, a shielded seal valve, transport vehicles, a portabie welder for sealing each drywell, and a 1/2-ton hydraulic hoist to lift and move the drywell cover. Drywells are added as required.

The drywell storage area is a graded area with 6 in. of compacted gravel between the drywells which are constructed on approximately $19 \mathrm{ft}$. centers. The storage area is connected to the transfer facility by a $300 \mathrm{ft}$. long and $30 \mathrm{ft}$. wide paved road. A $50 \mathrm{ft}$. buffer zone is provided around the perimeter of the storage area and is surrounded by an $8 \mathrm{ft}$. high chain link security fence topped by 3 strands of barbed wire. The bottom of the fence is anchored in concrete. A microwave security system is used to monitor the perimeter of the storage area, and the area is lighted. A security gate permits access of the transporters and inspection personnel to the storage area.

The canisters of spent fuel are moved to the storage area in a transfer cask. This cask is a modified NFS-4 type cask with the length extended to accommodate the 188-in. long canisters and equipped with a shielded, manually operated valve on the bottom end with a mating surface to fit into the shield valve at the drywell. The top of the cask has an easily removable head with an integral electrically operated winch to raise and lower the canisters. The transfer cask head is brought into the hot cell, positioned over the canister storage rack, and a canister is grappled and 1 ifted by the winch up to the head. The canister and head are lowered by the cell crane into the cask until the cask head mates with the cask. The head is clamped or bolted in place and the transfer cask is picked up vertically by the transporter, moved to a designated drywell, and mated with the shield vaive.

Both the valve in the bottom of the transfer cask and the shield valve are opened and the spent fuel canister is lowered into the drywell. After the retraction of the cable, both of the valves are closed and the transfer cask is returned to the transfer facility. A smaller cask containing the drywell plug is then positioned over the shield valve and mated. Both the 
valve in the bottom of the plug cask and the shield valve are then opened and the plug is lowered into the top of the drywell cavity. After retraction of the cable, the plug cask and the shield valve are lifted together and moved to the next empty drywell position. The cable from the plug cask is lowered to engage the pintle on the plug and the plug is withdrawn into the plug cask. Both the valve on the bottom of the plug cask and the shield valve are then closed and the plug cask is removed. The above process is then repeated.

After loading of each drywell, a steel cover is placed on the top of the drywell and is weided to the top of the drywell liner.

Two transporters are used to move the transfer casks and the plug cask/shield valve. Both consist of comnercially available straddie cranes having a 60-ton lift, and which are modified with a special strongback. The speed of these transporters is limited to $130 \mathrm{ft}$. per minute. The straddle crane is mounted on single rubber tires on all four corners and is driven by a gasoline engine. It can operate on both gravel and paved roads and can negotiate grades up to $6 \%$. It has the capability of making a $90^{\circ}$ turn.

\subsection{SILO STORAGE FACILITIES}

The storage of canistered spent fuel in concrete silos requires a storage area with concrete stands to support the silos and a transporter to move the loaded silo from the transfer facility to a storage pad. Storage stands are added as required.

The silo storage area is a graded area with 6 in. of compacted gravel between the reinforced concrete silo storage stands. Each storage stand is a $16-i n$. thick, reinforced concrete slab $16 \mathrm{ft}$. wide by $32 \mathrm{ft}$. long which provides storage space for 2 silos. The stands are spaced $10 \mathrm{ft}$. apart in rows with a $25 \mathrm{ft}$. spacing (roadway) between each row of stands. The storage area is connected to the transfer facility by a $300 \mathrm{ft}$. long and 30 $\mathrm{ft}$. wide paved road. A $50 \mathrm{ft}$. buffer zone is provided around the perimeter of the storage area and is surrounded by a $8 \mathrm{ft}$. high chain link security fence topped with 3 strands of barbed wire. The bottom of the fence is anchored in concrete. A microwave security system is used to monitor the perimeter of the storage area and the area is 1 ighted. A security gate permits access of the transporter and inspection personnel to the storage area. A transporter similar to that described for cask storage is used to transport the loaded silos from the transfer facility to the concrete stands in the storage area. 


\begin{abstract}
6.4 ESTIMATED COSTS
Estimates were made of the capital cost of the storage area facilities required for the six levels of capacity considered for each dry storage method addressed in this study. A listing of these costs is set forth in Table A6-1 for government facilities which have existing transfer facilities and for those without such facilities.
\end{abstract}


TABLE A6-1

ESTIMATED INITIAL CAPITAL COSTS FOR STORAGE AREA FACILITIES ${ }^{2}$

$(\$ 000,1989)$

Storage Method

\begin{tabular}{|c|c|c|c|c|c|c|}
\hline \multirow[b]{2}{*}{ Capacity } & \multicolumn{2}{|c|}{ Storage Cask } & \multicolumn{2}{|c|}{ Drywell } & \multicolumn{2}{|c|}{ silo } \\
\hline & $\begin{array}{c}\text { At Site } \\
\text { With Existing } \\
\text { Transfer } \\
\text { Facilities } \\
\end{array}$ & $\begin{array}{c}\text { At Site with } \\
\text { No Existing } \\
\text { Transfer } \\
\text { Facilities }\end{array}$ & $\begin{array}{c}\text { At site } \\
\text { With Existing } \\
\text { Transfer } \\
\text { Facilities } \\
\end{array}$ & $\begin{array}{c}\text { At site with } \\
\text { No Existing } \\
\text { Transfer } \\
\text { Facilities } \\
\end{array}$ & $\begin{array}{c}\text { At Site } \\
\text { With Existing } \\
\text { Transfer } \\
\text { Facilities } \\
\end{array}$ & $\begin{array}{c}\text { At Site with } \\
\text { No Existing } \\
\text { Transfer } \\
\text { Facilities } \\
\end{array}$ \\
\hline $50 \mathrm{MTU}$ & $\$ 2,144$ & $\$ 1,929$ & $\$ 5,931$ & $\$ 5,717$ & $\$ 2,805$ & $\$ 2,590$ \\
\hline $100 \mathrm{MTU}$ & 2,183 & 1,968 & 6,075 & 5,859 & 2,988 & 2,773 \\
\hline $300 \mathrm{MTU}$ & 2,301 & 2,085 & 6,545 & 6,330 & 3,650 & 3,434 \\
\hline $800 \mathrm{MTU}$ & 2,546 & 2,330 & 7,554 & 7,339 & 5,165 & 4,950 \\
\hline 1500 MTU & 2,869 & 2,654 & 8,853 & 8,637 & 7,204 & 6,990 \\
\hline I $900 \mathrm{MTU}$ & 3,044 & 2,829 & 9,571 & 9,356 & 8,351 & 8,136 \\
\hline
\end{tabular}

\footnotetext{
${ }^{\mathrm{a}}$ Storage area facilities at a site with existing transfer facilities include a security guard house;

in the case of a new transfer facility the guard house was included in the cost of the transfer facility.
} 

7.0 OPERATING COSTS FOR FIS SYSTEM

7.1 LOADING, STORAGE ANO REMOVAL

Estimates were made of the cost of operation of the FIS system for spent fuel storage at the six capacity levels considered for each dry storage method addressed in this study, and for both government sites which have no existing transfer facilities and those which do.

A listing of the total annual operating costs of FIS facilities during the years in which spent fuel is being loaded into or removed therefrom is set forth in Table A7-1 for each of the cases studied. A listing of the total annual operating costs during the years in which storage-only takes place is set forth in Table A7-2 for each of the cases studied. 
TABLE A7-1

ESTIMATED ANNUAL OPERATING COSTS FOR TRANSFER FACILITIES AND STORAGE FACILITIES

DURING LOADING AND REMOVAL OPERATIONS

$(\$ 000,1989)$

Storage Method

\begin{tabular}{|c|c|c|c|c|c|}
\hline \multicolumn{2}{|c|}{ Storage Cask } & \multicolumn{2}{|c|}{ Drywell } & \multicolumn{2}{|c|}{ Silo } \\
\hline $\begin{array}{l}\text { At Site } \\
\text { lith Existing } \\
\text { Transfer } \\
\text { Facilities } \\
\end{array}$ & $\begin{array}{c}\text { At Site With } \\
\text { No Existing } \\
\text { Transfer } \\
\text { Facilities }\end{array}$ & $\begin{array}{c}\text { At Site } \\
\text { With Existing } \\
\text { Transfer } \\
\text { Facilities }\end{array}$ & $\begin{array}{c}\text { At Site with } \\
\text { No Existing } \\
\text { Transfer } \\
\text { Facilities }\end{array}$ & $\begin{array}{c}\text { At Site } \\
\text { With Existing } \\
\text { Transfer } \\
\text { Facilities }\end{array}$ & $\begin{array}{l}\text { At Site with } \\
\text { No Existing } \\
\text { Transfer } \\
\text { Facilities }\end{array}$ \\
\hline$\$ 1,831$ & $\$ 1,924$ & $\$ 2,008$ & $\$ 2,077$ & $\$ 1,915$ & $\$ 1,984$ \\
\hline 1,904 & 1,998 & 2,145 & 2,214 & 2,031 & 2,101 \\
\hline 2,186 & 2,279 & 2,682 & 2,751 & 2,389 & 2,459 \\
\hline 3,021 & 3,114 & 4,152 & 4,222 & 3,664 & 3,733 \\
\hline 4,298 & 4,391 & 6,365 & 6,434 & 5,062 & 5,131 \\
\hline 5,028 & 5,121 & 7,630 & 7,699 & 5,862 & 5,931 \\
\hline
\end{tabular}


TABLE $A 7-2$

ESTIMATED ANNUAL OPERATING COSTS FOR STORAGE FACILITIES

AT GOVERNMENT SITE DURING STORAGE ONLY PERIOD

$(\$ 000,1989)$

Storage Method

\begin{tabular}{|c|c|c|c|c|c|}
\hline \multicolumn{2}{|c|}{ Storage Cask } & \multicolumn{2}{|c|}{ Drywell } & \multicolumn{2}{|c|}{ Silo } \\
\hline $\begin{array}{c}\text { At Site } \\
\text { With Existing } \\
\text { Transfer } \\
\text { Facilities }\end{array}$ & $\begin{array}{c}\text { At Site With } \\
\text { No Existing } \\
\text { Transfer } \\
\text { Facilities } \\
\end{array}$ & $\begin{array}{c}\text { At Site } \\
\text { With Existing } \\
\text { Transfer } \\
\text { Facilities }\end{array}$ & $\begin{array}{c}\text { At Site with } \\
\text { No Existing } \\
\text { Transfer } \\
\text { Facilities } \\
\end{array}$ & $\begin{array}{c}\text { At Site } \\
\text { With Existing } \\
\text { Transfer } \\
\text { Facilities } \\
\end{array}$ & $\begin{array}{c}\text { At Site With } \\
\text { No Existing } \\
\text { Transfer } \\
\text { Facilities } \\
\end{array}$ \\
\hline$\$ 1,015$ & $\$ 1,873$ & $\$ 1,168$ & $\$ 1,945$ & $\$ 1,107$ & $\$ 1,901$ \\
\hline 1,044 & 1,904 & 1,188 & 1,967 & 1,132 & 1,922 \\
\hline 1,160 & 2,018 & 1,264 & 2,048 & 1,216 & 2,007 \\
\hline 1,444 & 2,416 & 1,449 & 2,253 & 1,433 & 2,470 \\
\hline 1,850 & 3,084 & 1,749 & 2,920 & 1,734 & 2,928 \\
\hline $2,0 B 2$ & 3,468 & 1,922 & 3,303 & 1,908 & 3,192 \\
\hline
\end{tabular}




\subsection{DECONTAMINATION AND DECOMMISSIDNING}

In addition to the operating costs listed in Tables A7-1 and A7-2 for the various methods of storage considered, the cost of decontamination and decommissioning of the storage facilities at the end of their useful life was estimated. These costs were assumed to amount to 20 percent of the capital cost of transfer facilities, storage area facilities and storage modules. In the case of storage at a government site which has existing transfer facilities, only the capital cost of additions and modifications to the facilities were included in the calculation inasmuch as it was reasoned that the existing facilities would otherwise have had to be decommissioned by the government in the absence of the FIS system. 
8.0 OTHER ASSOCIATED STORAGE COSTS

8.1 GOVERNMENT ADMINSTRATIVE COSTS

An estimated allowance for government administrative costs associated with the FIS program was developed which assumed that the Department's administration of the program would be handled by a Program Manager assisted to the extent necessary by another program person, an accountant, and a clerical person. The following Table AB-l sets forth the total estimated annual costs for this administrative activity including storage fund management.

TABLE AB-1

ESTIMATED ANNUAL COSTS FOR GOVERNMENT ADMINISTRATION ASSOCIATED

WITH FEOERAL INTERIM STORAGE

$(\$ 000,1989)$

Total Capacity of FIS Facilities

\begin{tabular}{llllll}
\hline 50 & 100 & 300 & 800 & 1,500 & 1,900 \\
MTU & MTU & MTU & MTU & MTU & $\underline{\text { MTU }}$
\end{tabular}

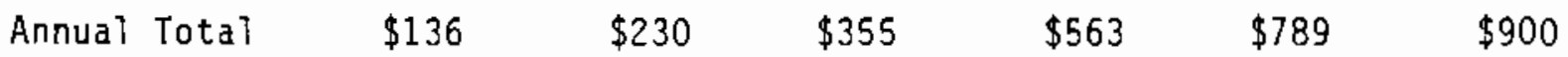

\subsection{FIS DEVELOPMENT COSTS}

The Act provides that the Department may establish a research and development program for the dry storage of up to 300 MTU of spent fuel at facilities owned by the government (Sec. 218(c)), that the total contributions from federal funds shall not exceed 25 percent of the program costs (Sec. 218(d)), and that the remaining costs of such program shall be paid for by the utilities involved or shall be provided from the interim storage fund (Sec. 218(d)). For the purposes of this study, it has been assumed that all of the costs in excess of the contribution of 25 percent of the program costs from Federal funds will be borne by the utility involved in the research and development program and, therefore, none of the costs associated with the program will be inciuded in the fee for FIS. 
However, the Act provides that funds required for the development of FIS facilities may be obtained from the storage fund (Sec. 136(d)(1)) and, therefore, will have to be included in the calculation of the fee for FIS in order to allow the Department to realize recovery of costs incurred in connection with FIS activities, as provided in Sec. 136(f)(6) of the Act. It is estimated that the costs associated with the development of the FIS program will amount to about \$3.78-million and will be incurred in accordance with the following estimated schedule of expenditures:

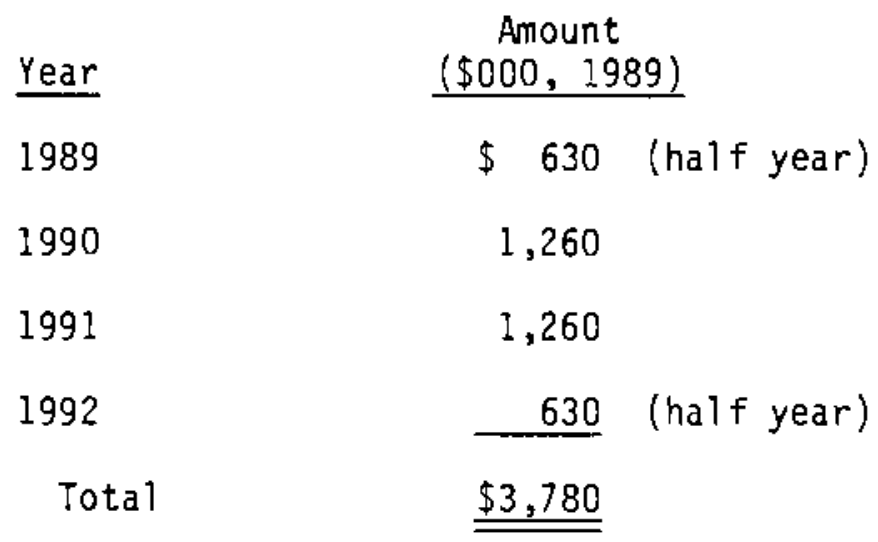

\subsection{IMPACT AID}

The cost of impact aid was estimated on the following basis:

(1) Impact aid will commence at the beginning of CY-1989 and will be terminated at the end of $\mathrm{CY}-2006$.

(2) The total impact aid will amount to the lesser of the following alternatives:

(a) $10 \%$ of the total cost of establishing and operating the FIS system -- including all capital, operating and decommissioning costs of the storage facilities involved, plus a pro rata share of research and development, government administration and trust fund management, but will exclude the cost of shipping.

(b) $\$ 15 / \mathrm{kgU}$ contained in the spent fuel stored.

(3) One-third of the total impact aid has been included in the Initial Payment, and two-thirds of the impact aid has been included in the final payment. 


\subsection{TOTAL COST OF FIS STORAGE}

The total cost associated with FIS storage was computed for each combination of storage method, capacity and location which was studied using the applicable elements of cost developed in Sections 1.0 through 8.0 of this Exhibit A, and an estimated annual spending schedule (in 1989 dollars) was developed for each such case. The annual costs which were estimated to be incurred prior to the startup of the FIS system plus the annual costs of the storage modules required (the component to be inciuded in the Initial Payment), and the annual costs which were estimated to be incurred after startup through decomissioning (the component to be included in the final Payment), were separately discounted to 1989 at a discount rate of $2 \%$ /year.

The Initial payments were calculated by equating the total discounted costs estimated to be incurred prior to startup of the FIS system and the discounted revenues (which are equal to the discounted quantities times a uniform unit cost) and solving the equality for the unknown value, i.e., the unit cost. Since the Initial Payment is assumed to be made in 1989 for all spent fuel to be stored, the revenues would be as follows:

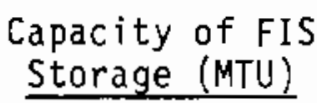

50
100
300
800
1500
1900

\section{Revenues}

$50 \mathrm{P}_{1}$
$100 \mathrm{P}_{1}^{1}$
$300 \mathrm{P}_{1}$
$800 \mathrm{P}_{1}$
$1,500 \mathrm{P}_{1}$
$1,900 \mathrm{P}_{\mathrm{I}}$

where $P_{1}$ is the unit cost (or Initial Payment)

The Finat Payments were similarly calculated using the discounted total costs estimated to be incurred after startup of the FIS system and the discounted revenues set forth in Table A9-1.

The estimated spending schedules, discounted annual costs and the calculation of the Initial and Final Payments for FIS of spent fuel for each of the cases studied are set forth in Tables A9-2 through A9-37. 
TABLE A9-1

ANNUAL AND DISCOUNTEO REYERUES RECEIYED FROM FINAL PAYMENTS FOR FIS SERVICES

\begin{tabular}{|c|c|c|c|c|c|c|c|c|c|c|c|c|c|c|c|c|c|}
\hline \multirow[b]{3}{*}{ Year } & \multicolumn{17}{|c|}{ Capacity } \\
\hline & \multicolumn{2}{|c|}{50 मтU } & \multicolumn{2}{|c|}{$100 \mathrm{MTU}$} & \multicolumn{3}{|c|}{$300 \mathrm{MTU}$} & \multicolumn{3}{|c|}{$800 \mathrm{MTU}$} & \multicolumn{4}{|c|}{$1500 \mathrm{kTU}$} & \multicolumn{3}{|c|}{1900 MTU } \\
\hline & Rey. & $\begin{array}{l}\text { Disc. } \\
\text { To } 1989 \\
\text { 2 } 23 / Y_{r}\end{array}$ & Rev. & $\begin{array}{r}\text { Disc. } \\
\text { To } 1989 \\
\text { 22/Yr }\end{array}$ & Rey. & $\begin{array}{r}\text { D1sc. } \\
\text { To } 1989 \\
3 \quad 21 / Y \mathrm{~T}\end{array}$ & & Rev. & & $\begin{array}{l}\text { Disc. } \\
\text { To } 1989 \\
\text { e 2W/Yr } \\
\end{array}$ & Rev. & & $\begin{array}{r}015 \mathrm{c} . \\
\text { To } 1989 \\
\text { e 27/4T } \\
\end{array}$ & & Rev. & & $\begin{array}{r}\text { Oisc, } \\
\text { To } 1989 \\
0 \quad 2 \% / Y r \\
\end{array}$ \\
\hline 1992 & $\$ B P_{2}$ & $\$ 7.5 \mathrm{P}_{2}$ & $\$ 17 P_{2}$ & $\$ 16.0 P_{2}$ & $\$ 50 \mathrm{P}_{2}$ & $\$ 47.1$ & $P_{2}$ & $\$ 133$ & $P_{2}$ & $\$ 125.3 P_{2}$ & $\$ 250$ & $P_{2}$ & \$ 235.6 & $P_{2}$ & $\$ 317$ & $P_{2}$ & \& 298.7 \\
\hline 1993 & $\$ 17 P_{2}$ & $15.7 \mathrm{P}_{2}$ & $33 \mathrm{P}_{2}$ & $30.5 P_{2}$ & $100 P_{2}$ & 92.4 & $P_{2}$ & 267 & $P_{2}$ & $246.7 \mathrm{P}_{2}$ & 500 & $P_{2}$ & 461.9 & $\mathbf{P}_{2}$ & 633 & $P_{2}$ & 584.8 \\
\hline 1994 & $17 \mathrm{P}_{2}$ & $15.4 \mathrm{P}_{2}$ & $33 \mathrm{P}_{2}$ & $29.9 P_{2}$ & $100 P_{2}$ & 90.6 & $\mathrm{P}_{2}$ & 267 & $P_{2}$ & $241.8 \mathrm{P}_{2}$ & 500 & $P_{2}$ & 452.9 & $P_{2}$ & 633 & $P_{2}$ & 573.3 \\
\hline 1995 & $\stackrel{8}{P_{2}}$ & $7.1 P_{2}$ & $\stackrel{17}{P_{2}}$ & $15.1{ }^{P} 2$ & $50 \mathrm{P}_{2}$ & 44.4 & $P_{2}$ & 133 & $P_{2}$ & $118.1 P_{2}$ & 250 & $\mathbf{P}_{2}$ & 222.0 & $P_{2}$ & 317 & $\mathrm{P}_{2}$ & 281.5 \\
\hline Total & $\$ 50 P_{2}$ & $\$ 45.7 \mathrm{P}_{2}$ & $\$ 100 P_{2}$ & $\$ 91.5 P_{2}$ & $\stackrel{300}{=} \mathrm{P}_{2}$ & $\$ 274.5$ & $P_{2}$ & $\$ 800$ & $P_{2}$ & $\$ 731.9 P_{2}$ & $\$ 1500$ & $P_{2}$ & $\$ 1372.4$ & $\mathbf{P}_{2}$ & $\$ 1900$ & $P_{2}$ & $\$ 1738.3$ \\
\hline
\end{tabular}

assumes revenues recelved in first three years after startup on a untform basis

$P_{2}=$ Final Payment 
TABLE A9-2

ESTIMATED SPENDINO BCHEDULE FOR GTORAGE OF I CASKS ( SO MTU) AT GOVERNMENT GITE WITHOUT EXISTING FACILITIES

$(1000,1989)$

\begin{tabular}{|c|c|c|c|c|c|c|c|c|}
\hline YEAR & $\begin{array}{l}\text { TRANS } \\
\text { FACIL } \\
\text { COSTS }\end{array}$ & $\begin{array}{l}\text { BTOR } \\
\text { AREA } \\
\text { COSTS }\end{array}$ & $\begin{array}{l}\text { MDDULE } \\
\text { COSTS }\end{array}$ & $\begin{array}{r}\text { OPERAT } \\
\text { COSTB }\end{array}$ & $\begin{array}{l}\text { FIS } \\
\text { DEVEL } \\
\text { COOT8 }\end{array}$ & $\begin{array}{l}\text { ODVT. } \\
\text { ADMIN } \\
\text { CDSTS }\end{array}$ & $\begin{array}{l}\text { TOTAL } \\
\text { COSTS }\end{array}$ & $\begin{array}{l}\text { DISC. } \\
\text { TOTAL. } \\
\text { COSTS }\end{array}$ \\
\hline $\begin{array}{l}1999 \\
1990 \\
1991 \\
1992 \\
1993 \\
1994 \\
1995 \\
1996 \\
1997 \\
1999 \\
1999 \\
2000 \\
2001 \\
2002 \\
2003 \\
2004 \\
2005 \\
2006\end{array}$ & $\begin{array}{r}3432 \\
249 \\
8653 \\
8530\end{array}$ & $\begin{array}{r}1073 \\
145 \\
392 \\
319\end{array}$ & $\begin{array}{r}692 \\
1783 \\
1783 \\
892\end{array}$ & $\begin{array}{l}962 \\
1924 \\
1924 \\
1899 \\
1673 \\
1673 \\
1673 \\
1673 \\
1873 \\
1873 \\
1873 \\
1924 \\
1924 \\
1924 \\
56291\end{array}$ & $\begin{array}{r}630 \\
1260 \\
1260 \\
630\end{array}$ & $\begin{array}{l}136 \\
136 \\
136 \\
136 \\
136 \\
136 \\
136 \\
136 \\
136 \\
136 \\
136 \\
136 \\
136 \\
136 \\
136 \\
136 \\
136 \\
136\end{array}$ & $\begin{array}{r}3271 \\
1790 \\
10443 \\
11469 \\
3843 \\
3843 \\
2927 \\
2009 \\
2009 \\
2009 \\
2009 \\
2009 \\
2009 \\
2009 \\
2060 \\
2060 \\
2060 \\
3765\end{array}$ & $\begin{array}{r}5271 \\
1755 \\
10037 \\
10807 \\
3550 \\
3481 \\
2599 \\
1749 \\
1713 \\
1681 \\
1648 \\
1616 \\
1584 \\
1553 \\
1561 \\
1531 \\
1501 \\
4117\end{array}$ \\
\hline TOTAL & 20866 & 1929 & 5350 & 31221 & 3780 & 2448 & 65594 & 57756 \\
\hline
\end{tabular}

- - decommissidning cost

INITIAL PAYMENT = $624 / K g U$ (INCLUDES $5 / K g U$ IMPACT AID)

FINAL PAYRENT * 596 \$KOU (INCLUDES 10/KoU IMPACT AID)

TABLE A9-3

ESTIMATED SPENDING SCHEDULE FOR ETORAGE OF 10 CASKS ( 100 MTU) AT GOVERNMENT SITE WITHOUT EXISTING FACILITIES $(1000,1989)$

\begin{tabular}{|c|c|c|c|c|c|c|c|c|}
\hline YEAR & $\begin{array}{l}\text { TRANS } \\
\text { FACIL } \\
\text { COSTS }\end{array}$ & $\begin{array}{l}\text { BTOR } \\
\text { AREA } \\
\text { COSTS }\end{array}$ & $\begin{array}{l}\text { MODLLE } \\
\text { COSTS }\end{array}$ & $\begin{array}{r}\text { OPERAT } \\
\text { CDSTS }\end{array}$ & $\begin{array}{l}\text { F IS } \\
\text { DEVEL } \\
\text { COSTS }\end{array}$ & $\begin{array}{l}\text { GOVT } \\
\text { ADMIN } \\
\text { COSTS }\end{array}$ & $\begin{array}{l}\text { TOTAL } \\
\text { COSTS }\end{array}$ & $\begin{array}{l}\text { DIGC. } \\
\text { TOTAL } \\
\text { COSTS }\end{array}$ \\
\hline $\begin{array}{l}1989 \\
1990 \\
1991 \\
1992 \\
1993 \\
1994 \\
1995 \\
1996 \\
1997 \\
1998 \\
1999 \\
2000 \\
2001 \\
2002 \\
2003 \\
2004 \\
2005 \\
2006\end{array}$ & $\begin{array}{r}3432 \\
249 \\
8655 \\
8530\end{array}$ & $\begin{array}{r}1079 \\
145 \\
409 \\
336\end{array}$ & $\begin{array}{l}1793 \\
3567 \\
3567 \\
1783\end{array}$ & $\begin{array}{l}999 \\
1990 \\
1999 \\
1951 \\
1904 \\
1904 \\
1904 \\
1904 \\
1904 \\
1904 \\
1904 \\
1998 \\
1990 \\
1998 \\
67074\end{array}$ & $\begin{array}{r}630 \\
1260 \\
1260 \\
630\end{array}$ & $\begin{array}{l}230 \\
230 \\
230 \\
230 \\
230 \\
230 \\
230 \\
230 \\
230 \\
230 \\
230 \\
230 \\
230 \\
230 \\
230 \\
230 \\
230 \\
230\end{array}$ & $\begin{array}{r}5370 \\
1884 \\
10554 \\
12508 \\
5795 \\
5795 \\
3964 \\
2134 \\
2134 \\
2134 \\
2134 \\
2134 \\
2134 \\
2134 \\
2228 \\
2228 \\
2228 \\
6937\end{array}$ & $\begin{array}{r}5370 \\
1847 \\
10144 \\
11787 \\
5354 \\
5249 \\
3520 \\
1858 \\
1821 \\
1786 \\
1751 \\
1716 \\
1683 \\
1650 \\
1689 \\
1655 \\
1623 \\
4954\end{array}$ \\
\hline TOTAL & 20066 & 1968 & 10700 & 32975 & 3780 & 4140 & 74429 & 65457 \\
\hline
\end{tabular}

- decommisgioning Cost

INITIAL PAYMENT - 367 * $/ \mathrm{KU}$ (INCLUDES $\$ / K g U$ IMPACT AID)

final PAYMENT - 330 Kgl (INCLUdEs * 10/KoU IMPACT AID) 
IABLE A9-4

ESTIMATED SPENDING SCHEDULE FOR gTORAGE OF 29 CASKS ( $300 \mathrm{MTU}$ ) AT GOVERNMENT OITE WITHOUT EXIGTINO FACILITIEG

$(\$ 000,1989)$

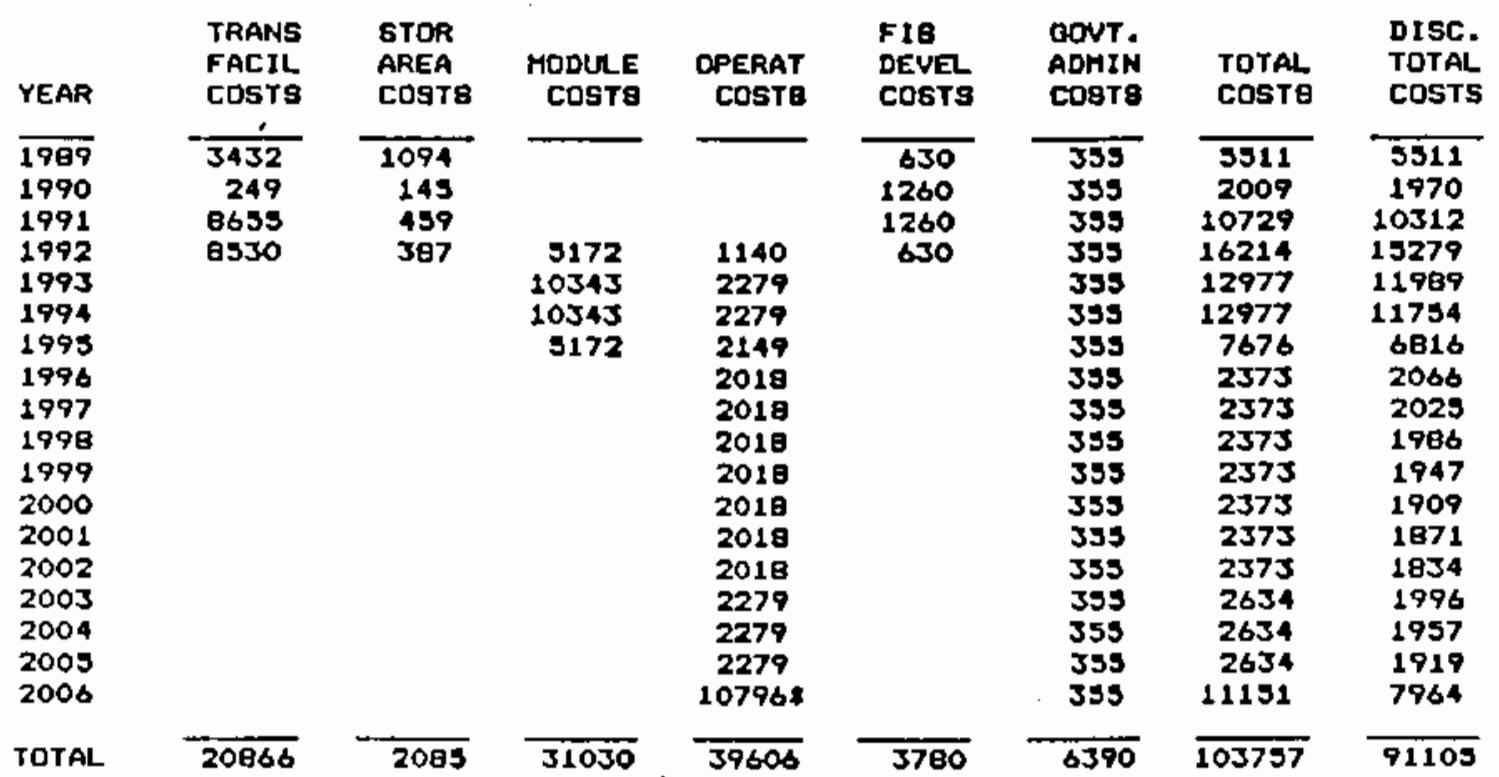

- Decommissioning COST

INITIAL PAYMENT - $199 * / \mathrm{KgU}$ (INCLUDES $5 / \mathrm{KOU}$ IMPACT AID)

FINAL PAMMENT = 140 KgU (INCLUDES $10 / \mathrm{KgU}$ IMPACT AID)

TABLE A9-5

ESTIMATED SPENDING SCHEDULE FOR GTORAGE OF 76 CASKS ( 800 MTU)

AT GOVERNMENT SITE WITHOUT EXISTING FACILITIES

$(\$ \infty 00,1989)$

\begin{tabular}{|c|c|c|c|c|c|c|c|c|}
\hline YEAR & $\begin{array}{l}\text { TRANS } \\
\text { FACIL } \\
\text { COSTS }\end{array}$ & $\begin{array}{l}\text { STOR } \\
\text { AREA } \\
\text { COSTg }\end{array}$ & $\begin{array}{r}\text { MODULE } \\
\text { CosTs }\end{array}$ & $\begin{array}{r}\text { OPERAT } \\
\text { COSTE }\end{array}$ & $\begin{array}{l}\text { FIB } \\
\text { DEVEL } \\
\text { COSTg }\end{array}$ & $\begin{array}{l}\text { GOVT. } \\
\text { ADHIN } \\
\text { COSTS }\end{array}$ & $\begin{array}{l}\text { TOTAL } \\
\text { COSTS }\end{array}$ & $\begin{array}{l}\text { DISC. } \\
\text { TDTAL } \\
\text { COSTS }\end{array}$ \\
\hline $\begin{array}{l}1999 \\
1990 \\
1991 \\
1992 \\
1993 \\
1994 \\
1995 \\
1996 \\
1997 \\
1998 \\
1999 \\
2000 \\
2001 \\
2002 \\
2003 \\
2004 \\
2005 \\
2006\end{array}$ & $\begin{array}{r}3432 \\
249 \\
9653 \\
8530\end{array}$ & $\begin{array}{r}1126 \\
145 \\
566 \\
493\end{array}$ & $\begin{array}{l}13553 \\
27107 \\
27107 \\
13553\end{array}$ & $\begin{array}{l}1557 \\
3114 \\
3114 \\
2765 \\
2416 \\
2416 \\
2416 \\
2416 \\
2416 \\
2416 \\
2416 \\
3114 \\
3114 \\
3114 \\
20903\end{array}$ & $\begin{array}{r}630 \\
1260 \\
1260 \\
630\end{array}$ & $\begin{array}{l}563 \\
563 \\
563 \\
563 \\
563 \\
563 \\
563 \\
563 \\
563 \\
363 \\
563 \\
563 \\
563 \\
563 \\
563 \\
563 \\
563 \\
563\end{array}$ & $\begin{array}{r}5751 \\
2217 \\
11044 \\
25326 \\
30784 \\
30784 \\
16891 \\
2979 \\
2979 \\
2979 \\
2979 \\
2979 \\
2979 \\
2979 \\
3677 \\
3677 \\
3677 \\
21466\end{array}$ & $\begin{array}{r}5751 \\
2174 \\
10615 \\
23865 \\
28440 \\
27892 \\
14990 \\
2593 \\
2543 \\
2493 \\
2444 \\
2396 \\
2349 \\
2303 \\
2787 \\
2732 \\
2679 \\
15330\end{array}$ \\
\hline TOTAL & 20866 & 2330 & 01320 & 57707 & 3780 & 10134 & 176137 & 154365 \\
\hline
\end{tabular}

- DEcomissioning COST

INITIAL PAYMENT = 133 /KgU (INCLUDES $5 / \mathrm{KgU}$ IMPACT AID)

FINAL PAYMENT = $B 1$ KgU (INCLUDES 10/KgU IMPACT AID) 
TABLE A9-6

ESTIMATED SPENDINO SCHEOUL FOR STORAGE OF 143 CASKS (1500 MTU) AT GOVERNMENT BITE WITHOUT EXISTING FACILITIES $(4000,1999)$

\begin{tabular}{|c|c|c|c|c|c|c|c|c|}
\hline YEAR & $\begin{array}{l}\text { TRANG } \\
\text { FACIL } \\
\text { COSTG }\end{array}$ & $\begin{array}{l}\text { STOR } \\
\text { AREA } \\
\text { COSTE }\end{array}$ & $\begin{array}{l}\text { MODULE } \\
\text { COSTB }\end{array}$ & $\begin{array}{r}\text { OPERAT } \\
\text { COSTB }\end{array}$ & $\begin{array}{l}\text { FIg } \\
\text { DEVEL } \\
\text { COSTB }\end{array}$ & $\begin{array}{l}\text { GOVT. } \\
\text { ADHIN } \\
\text { COSTS }\end{array}$ & $\begin{array}{l}\text { TOTAL } \\
\text { COSTE }\end{array}$ & $\begin{array}{l}\text { DISC. } \\
\text { TOTAL } \\
\text { COSTE }\end{array}$ \\
\hline $\begin{array}{l}1999 \\
1990 \\
1991 \\
1992 \\
1993 \\
1994 \\
1995 \\
1996 \\
1997 \\
1998 \\
1999 \\
2000 \\
2001 \\
2002 \\
2003 \\
2004 \\
2005 \\
2006\end{array}$ & $\begin{array}{r}3432 \\
249 \\
8653 \\
8530\end{array}$ & $\begin{array}{r}1168 \\
145 \\
707 \\
634\end{array}$ & $\begin{array}{l}25502 \\
51003 \\
51003 \\
25502\end{array}$ & $\begin{array}{c}2196 \\
4391 \\
4391 \\
3738 \\
3094 \\
3094 \\
3084 \\
3084 \\
3084 \\
3094 \\
3084 \\
4391 \\
4391 \\
4391 \\
333064\end{array}$ & $\begin{array}{r}630 \\
1260 \\
1260 \\
630\end{array}$ & $\begin{array}{l}789 \\
789 \\
789 \\
769 \\
789 \\
789 \\
789 \\
789 \\
789 \\
789 \\
789 \\
789 \\
789 \\
789 \\
789 \\
789 \\
789 \\
789\end{array}$ & $\begin{array}{r}6019 \\
2443 \\
11411 \\
38291 \\
56183 \\
56183 \\
30029 \\
3873 \\
3873 \\
3873 \\
3873 \\
3873 \\
3873 \\
3873 \\
5180 \\
5180 \\
3180 \\
36095\end{array}$ & $\begin{array}{r}6019 \\
2395 \\
10968 \\
36073 \\
51904 \\
50967 \\
26665 \\
3372 \\
3306 \\
3241 \\
3177 \\
3115 \\
3054 \\
2994 \\
3926 \\
3849 \\
3773 \\
25778\end{array}$ \\
\hline TOTAL & 20066 & 2654 & 153010 & 84783 & 3780 & 14202 & 279295 & 244496 \\
\hline
\end{tabular}

* decommissioning cost

INITIAL PAYMENT = 118 /KgU (INCLUDEg S/KOU IMPACT AID)

FINAL PAYMENT = 65 KQU (INCLUDES $10 / \mathrm{KgU}$ IMPACT AYD)

TABLE A9-7

ESTIMATED SPENDING SCHEDULE FOR STORAGE OF 191 CASKS ( $1900 \mathrm{MTU}$ ) AT GOVERNMENT SITE WITHDUT EXISTING FACILITIES

$(\$ 000,1989)$

\begin{tabular}{|c|c|c|c|c|c|c|c|c|}
\hline YEAR & $\begin{array}{l}\text { TRANS } \\
\text { FACIL } \\
\text { COSTS }\end{array}$ & $\begin{array}{l}\text { STOR } \\
\text { AREA } \\
\text { COSTB }\end{array}$ & $\begin{array}{l}\text { MODULE } \\
\text { COSTS }\end{array}$ & $\begin{array}{r}\text { OPERAT } \\
\text { COSTS }\end{array}$ & $\begin{array}{l}\text { FIS } \\
\text { DEVEL } \\
\text { COSTS }\end{array}$ & $\begin{array}{l}\text { GOVT. } \\
\text { ADMIN } \\
\text { COSTA }\end{array}$ & $\begin{array}{l}\text { TOTAL } \\
\text { COSTS }\end{array}$ & $\begin{array}{l}\text { DISC. } \\
\text { TOTAL } \\
\text { Costs }\end{array}$ \\
\hline $\begin{array}{l}1909 \\
1990 \\
1991 \\
1992 \\
1993 \\
1994 \\
1995 \\
1996 \\
1997 \\
1998 \\
1999 \\
2000 \\
2001 \\
2002 \\
2003 \\
2004 \\
2005 \\
2006\end{array}$ & $\begin{array}{r}3432 \\
249 \\
6655 \\
8530\end{array}$ & $\begin{array}{r}1191 \\
145 \\
783 \\
710\end{array}$ & $\begin{array}{l}32276 \\
64357 \\
64557 \\
32270\end{array}$ & $\begin{array}{l}2561 \\
3121 \\
5121 \\
4293 \\
3468 \\
3468 \\
3468 \\
3468 \\
3468 \\
3468 \\
3468 \\
5121 \\
5121 \\
5121 \\
43473\end{array}$ & $\begin{array}{r}630 \\
1260 \\
1260 \\
630\end{array}$ & $\begin{array}{l}900 \\
900 \\
900 \\
900 \\
900 \\
900 \\
900 \\
900 \\
900 \\
900 \\
900 \\
900 \\
900 \\
900 \\
900 \\
900 \\
900 \\
900\end{array}$ & $\begin{array}{r}6153 \\
2554 \\
11390 \\
45609 \\
70379 \\
70578 \\
37473 \\
4368 \\
4369 \\
4368 \\
4368 \\
4368 \\
4368 \\
4368 \\
6021 \\
6021 \\
6021 \\
44373\end{array}$ & $\begin{array}{r}6153 \\
2504 \\
11149 \\
42978 \\
65203 \\
63925 \\
33275 \\
3803 \\
3728 \\
3655 \\
3583 \\
3513 \\
3444 \\
3377 \\
4563 \\
4474 \\
4386 \\
31690\end{array}$ \\
\hline
\end{tabular}

* Decommissianing cost

INITIAL PAYMENT = $114 \$ / K g U$ (INCLUDES $\$ / K g U$ IMPACT AID)

FINAL PAyMent a 61 KgU (INCLUDEs 10/KgU IMPACT AID) 
TABLE A9-B

ESTIMATED SPENDING SCHEDULE FOR GTDRAGE OF 11 B DRYWELLS (5O MTU) AT GOVERNHENT 8ITE WITHOUT EXISTING FACILITIES

$(\$ 000,2989)$

\begin{tabular}{|c|c|c|c|c|c|c|c|c|}
\hline YEAR & $\begin{array}{l}\text { TRANS } \\
\text { FACIL } \\
\text { COSTS }\end{array}$ & $\begin{array}{l}\text { STOR } \\
\text { AREA } \\
\text { COSTE }\end{array}$ & $\begin{array}{r}\text { MODLLE } \\
\text { COET8 }\end{array}$ & $\begin{array}{r}\text { DPERAT } \\
\text { COST8 }\end{array}$ & $\begin{array}{l}\text { FI8 } \\
\text { DEVEL } \\
\text { COST }\end{array}$ & $\begin{array}{l}\text { GOVT. } \\
\text { ADMIN } \\
\text { COSTS }\end{array}$ & $\begin{array}{l}\text { TOTAL } \\
\text { COETg }\end{array}$ & $\begin{array}{l}\text { DISC. } \\
\text { TOTAL } \\
\text { COSTS }\end{array}$ \\
\hline $\begin{array}{l}1999 \\
1990 \\
1991 \\
1992 \\
1993 \\
1994 \\
1995 \\
1996 \\
1997 \\
1999 \\
1999 \\
2000 \\
2001 \\
2002 \\
2003 \\
2004 \\
2005 \\
2006\end{array}$ & $\begin{array}{r}3654 \\
249 \\
9395 \\
9270\end{array}$ & $\begin{array}{r}1785 \\
155 \\
1927 \\
1850\end{array}$ & $\begin{array}{r}543 \\
1086 \\
1086 \\
543\end{array}$ & $\begin{array}{l}1039 \\
2077 \\
2077 \\
2011 \\
1945 \\
1945 \\
1945 \\
1945 \\
1945 \\
1945 \\
1945 \\
2077 \\
2077 \\
2077 \\
63098\end{array}$ & $\begin{array}{r}630 \\
1260 \\
1260 \\
630\end{array}$ & $\begin{array}{l}136 \\
236 \\
136 \\
136 \\
136 \\
236 \\
136 \\
136 \\
136 \\
136 \\
136 \\
136 \\
136 \\
136 \\
136 \\
136 \\
136 \\
136\end{array}$ & $\begin{array}{r}6205 \\
1800 \\
12718 \\
13469 \\
3299 \\
3299 \\
2690 \\
2091 \\
2091 \\
2091 \\
2091 \\
2081 \\
2081 \\
2091 \\
2213 \\
2213 \\
2213 \\
6445\end{array}$ & $\begin{array}{r}6205 \\
1765 \\
12224 \\
12691 \\
3049 \\
2998 \\
2309 \\
1812 \\
1776 \\
1741 \\
1707 \\
1674 \\
1641 \\
1609 \\
1677 \\
1644 \\
1612 \\
4603\end{array}$ \\
\hline TOTAL & 22568 & 5717 & 3298 & 33359 & 3700 & 2440 & 71130 & 62006 \\
\hline
\end{tabular}

- DeCOMmissidning COgT

INITIAL PAYMENT - 691 \%KOU (INCLUDES $\$ 5 / \mathrm{KgU}$ IMPACT AID)

FINAL PAYMENT $=633$ EKgU (INCLUDES $10 / \mathrm{KgU}$ IMPACT AID)

TABLE A9-9

ESTIMATED SPENDING SCHEOULE FOR BYORAGE OF 236 DRYHELLS ( 100 MTU) AT GOVERNMENT SITE WITHOUT EXISTING FACILITIES

(\$000, 1989)

\begin{tabular}{|c|c|c|c|c|c|c|c|c|}
\hline YEAR & $\begin{array}{l}\text { TRANS } \\
\text { FACIL } \\
\text { COSTS }\end{array}$ & $\begin{array}{l}\text { GTOR } \\
\text { AREA } \\
\text { COSTS }\end{array}$ & $\begin{array}{r}\text { MODULE } \\
\text { Costs }\end{array}$ & $\begin{array}{r}\text { OPERAT } \\
\text { COSTY }\end{array}$ & $\begin{array}{l}\text { FIS } \\
\text { DEVER } \\
\text { CDSTS }\end{array}$ & $\begin{array}{l}\text { GOVT. } \\
\text { ADMIN } \\
\text { COSTE }\end{array}$ & $\begin{array}{l}\text { TOTAL } \\
\text { COSTE }\end{array}$ & $\begin{array}{l}\text { DISC. } \\
\text { TOTAL } \\
\text { COSTS }\end{array}$ \\
\hline $\begin{array}{l}1999 \\
1990 \\
1991 \\
1992 \\
1993 \\
1994 \\
1995 \\
1996 \\
1997 \\
1999 \\
1999 \\
2000 \\
2001 \\
2002 \\
2003 \\
2004 \\
2005 \\
2006\end{array}$ & $\begin{array}{r}3654 \\
249 \\
9395 \\
9270\end{array}$ & $\begin{array}{r}1004 \\
155 \\
1989 \\
1911\end{array}$ & $\begin{array}{l}1086 \\
2171 \\
2171 \\
1006\end{array}$ & $\begin{array}{l}1107 \\
2214 \\
2214 \\
2091 \\
1967 \\
1967 \\
1967 \\
1967 \\
1967 \\
1967 \\
1967 \\
2214 \\
2214 \\
2214 \\
6908\end{array}$ & $\begin{array}{r}630 \\
1260 \\
1260 \\
630\end{array}$ & $\begin{array}{l}230 \\
230 \\
230 \\
230 \\
230 \\
230 \\
230 \\
230 \\
230 \\
230 \\
230 \\
230 \\
230 \\
230 \\
230 \\
230 \\
230 \\
230\end{array}$ & $\begin{array}{c}6310 \\
1994 \\
12974 \\
14234 \\
4615 \\
4615 \\
3407 \\
2197 \\
2197 \\
2197 \\
2197 \\
2197 \\
2197 \\
2197 \\
2444 \\
2444 \\
2444 \\
7218\end{array}$ & $\begin{array}{r}6318 \\
1957 \\
12374 \\
13413 \\
4264 \\
1180 \\
3025 \\
1913 \\
1975 \\
1838 \\
1902 \\
1767 \\
1732 \\
1698 \\
1852 \\
1916 \\
1780 \\
5155\end{array}$ \\
\hline TOTAL & 22568 & 3859 & 6514 & 35025 & 3780 & 4140 & 77886 & 68659 \\
\hline
\end{tabular}

- Decommissioning cost

INITIAL PAYMENT = 3B2 $\$ / K g U$ (INCLUDES $5 / K g U$ IMPACT AID)

FINAL PAYMENT - 349 KGU (INCLUDES 10/KgU IMPACT AID) 
TABLE A9-10

ESTIMATED SPENDINO SCHEDURE FOR STORAGE OF 707 DRYWEUIS ( 300 MTU) AT GOVERNMENT BITE HITHOUT EXISTING FACILITIES

$(1000,1989)$

\begin{tabular}{|c|c|c|c|c|c|c|c|c|}
\hline YEAR & $\begin{array}{l}\text { TRANS } \\
\text { FACIL } \\
\text { COSTS }\end{array}$ & $\begin{array}{l}\text { STOR } \\
\text { AREA } \\
\text { COSTB }\end{array}$ & $\begin{array}{r}\text { HDDULE } \\
\text { COSTA }\end{array}$ & $\begin{array}{r}\text { OPERAT } \\
\text { COSTE }\end{array}$ & $\begin{array}{l}\text { FIs } \\
\text { DEVEL } \\
\text { costs }\end{array}$ & $\begin{array}{l}\text { GOVT. } \\
\text { ADMIN } \\
\text { COSTS }\end{array}$ & $\begin{array}{l}\text { TOTAL } \\
\text { COSTS }\end{array}$ & $\begin{array}{l}\text { DISC. } \\
\text { TOTAL } \\
\text { COSTS }\end{array}$ \\
\hline $\begin{array}{l}1989 \\
1990 \\
1991 \\
1992 \\
1993 \\
1994 \\
1995 \\
1996 \\
1997 \\
1999 \\
1999 \\
2000 \\
2001 \\
2002 \\
2003 \\
2004 \\
2005 \\
2006\end{array}$ & $\begin{array}{r}3654 \\
249 \\
9395 \\
9270\end{array}$ & $\begin{array}{r}1863 \\
153 \\
2194 \\
2126\end{array}$ & $\begin{array}{l}3252 \\
6505 \\
6505 \\
3252\end{array}$ & $\begin{array}{l}1376 \\
2731 \\
2751 \\
2400 \\
2048 \\
2048 \\
2049 \\
2048 \\
2049 \\
2049 \\
2048 \\
2751 \\
2751 \\
2751 \\
96824\end{array}$ & $\begin{array}{r}630 \\
1260 \\
1260 \\
630\end{array}$ & $\begin{array}{l}355 \\
355 \\
355 \\
355 \\
355 \\
355 \\
355 \\
355 \\
355 \\
355 \\
355 \\
355 \\
355 \\
355 \\
355 \\
355 \\
355 \\
355\end{array}$ & $\begin{array}{r}6504 \\
2019 \\
13204 \\
26999 \\
9611 \\
9611 \\
6007 \\
2403 \\
2403 \\
2403 \\
2403 \\
2403 \\
2403 \\
2403 \\
3106 \\
3106 \\
3106 \\
10037\end{array}$ & $\begin{array}{r}6504 \\
1979 \\
12691 \\
16019 \\
0879 \\
8705 \\
5334 \\
2092 \\
2051 \\
2011 \\
1971 \\
1933 \\
1995 \\
1959 \\
2354 \\
2308 \\
2263 \\
7169\end{array}$ \\
\hline TDTAL & 22569 & 6330 & 19514 & 41549 & 3760 & $6 \overrightarrow{390}$ & $\overline{100131}$ & 00015 \\
\hline
\end{tabular}

* - decomissigning COSt

INITIAL PAYMENT = $173 * / K g U$ (INCLUDES $\$ 3 / \mathrm{KgU}$ IMPACT AID)

FINAL PAYMENT = 147 KGU (INCLUDES $10 / \mathrm{KgU}$ IMPACT AID)

IABLE A9-11

ESTIMATED SPENDING SCHEDULE FOR GTORAGE OF 1986 DRYWELLS ( $000 \mathrm{MTU}$ ) AT GOVERNMENT GITE WITHOUT EXISTINO FACILITIES

$(1000,1989)$

\begin{tabular}{|c|c|c|c|c|c|c|c|c|}
\hline YEAR & $\begin{array}{l}\text { TRANS } \\
\text { FACIL } \\
\text { COSTS }\end{array}$ & $\begin{array}{l}\text { STOR } \\
\text { AREA } \\
\text { COSTS }\end{array}$ & $\begin{array}{l}\text { MODULE } \\
\text { COSTS }\end{array}$ & $\begin{array}{r}\text { DPERAT } \\
\text { COSTB }\end{array}$ & $\begin{array}{l}\text { FI } \\
\text { DEVEL } \\
\text { COSTB }\end{array}$ & $\begin{array}{l}\text { GOVT. } \\
\text { ADHIN } \\
\text { COSTS }\end{array}$ & $\begin{array}{l}\text { TOTAL } \\
\text { Costg }\end{array}$ & $\begin{array}{l}\text { DISC. } \\
\text { TOTAL. } \\
\text { cosTs }\end{array}$ \\
\hline TOTAL & $2 \longdiv { 2 5 6 8 }$ & 7339 & 52056 & $5 \dot{6023}$ & $\overrightarrow{3780}$ & 10134 & 154500 & 135309 \\
\hline
\end{tabular}

* - decommissidning cost

INITIAL PAYMENT = $107 * / \mathrm{KgU}$ (INCLUDES $\$ / \mathrm{KgU}$ IMPACT AID)

FINAL PAYMENT - 63 \$KgL (INCLUDES * 10/KgU IMPACT AID) 
TABLE A9-12

ESTIMATED SPENDING SCHEDULE FOR STORAGE OF 3535 DRYWELLS ( 1500 MTU) AT GOVERNHENT GITE WITHOUT EXISTING FACILITIES $(1000,1989)$

\begin{tabular}{|c|c|c|c|c|c|c|c|c|}
\hline YEAR & $\begin{array}{l}\text { TRANS } \\
\text { FACIL } \\
\text { COSTS }\end{array}$ & $\begin{array}{l}\text { STOR } \\
\text { AREA } \\
\text { COST }\end{array}$ & $\begin{array}{l}\text { MODULE } \\
\text { COSTS }\end{array}$ & $\begin{array}{r}\text { OPERAT } \\
\text { COSTS }\end{array}$ & $\begin{array}{l}\text { FIB } \\
\text { DEVEL } \\
\text { COBTS }\end{array}$ & $\begin{array}{l}\text { BOVT. } \\
\text { ADHIN } \\
\text { COSTB }\end{array}$ & $\begin{array}{l}\text { TOTAL } \\
\text { COSTB }\end{array}$ & $\begin{array}{l}\text { DISC. } \\
\text { TOTAL } \\
\text { Costs }\end{array}$ \\
\hline $\begin{array}{l}1909 \\
1990 \\
1991 \\
1992 \\
1993 \\
1994 \\
1995 \\
1996 \\
1997 \\
1998 \\
1999 \\
2000 \\
2001 \\
2002 \\
2003 \\
2004 \\
2005 \\
2006\end{array}$ & $\begin{array}{r}3654 \\
249 \\
7395 \\
9270\end{array}$ & $\begin{array}{r}2166 \\
155 \\
3197 \\
3119\end{array}$ & $\begin{array}{l}16262 \\
32524 \\
32524 \\
16262\end{array}$ & $\begin{array}{l}3217 \\
6434 \\
6434 \\
4677 \\
2920 \\
2920 \\
2920 \\
2920 \\
2920 \\
2920 \\
2920 \\
6434 \\
6434 \\
6434 \\
25755\end{array}$ & $\begin{array}{r}630 \\
1260 \\
1260 \\
630\end{array}$ & $\begin{array}{l}789 \\
789 \\
789 \\
789 \\
789 \\
789 \\
789 \\
789 \\
789 \\
789 \\
789 \\
789 \\
789 \\
789 \\
789 \\
789 \\
789 \\
789\end{array}$ & $\begin{array}{r}7239 \\
2433 \\
14641 \\
33297 \\
39747 \\
39747 \\
21726 \\
3709 \\
3709 \\
3709 \\
3709 \\
3709 \\
3709 \\
3709 \\
7223 \\
7223 \\
7223 \\
26544\end{array}$ & $\begin{array}{r}7239 \\
2405 \\
14072 \\
31367 \\
36720 \\
36000 \\
19294 \\
3229 \\
3166 \\
3104 \\
3043 \\
2963 \\
2925 \\
2867 \\
5474 \\
5367 \\
5262 \\
18957\end{array}$ \\
\hline TOTAL & 22563 & 8637 & 97572 & 06259 & 3780 & 14202 & 233018 & 203474 \\
\hline
\end{tabular}

* - Decomatssioning Cost

INITIAL PAYMENT = 99 \$ $/ \mathrm{K}$

FINAL PAYMENT $=67$ \$KOU (INCLUDES $10 / \mathrm{KgU}$ IMPACT AID)

TABLE A9-13

EST IMATED SPENOINO SCMEDULE FOR BTORADE OF 4479 DRYWELLS ( 1900 MTU) AT GOVERNMENT GITE WITHOUT EXIGTING FACILITIES $(1000,1989)$

\begin{tabular}{|c|c|c|c|c|c|c|c|c|}
\hline YEAR & $\begin{array}{l}\text { TRANS } \\
\text { FACIL } \\
\text { COST }\end{array}$ & $\begin{array}{l}\text { gTOR } \\
\text { AREA } \\
\text { CosTB }\end{array}$ & $\begin{array}{r}\text { MDOLEE } \\
\text { CDQTE }\end{array}$ & $\begin{array}{l}\text { OPERAT } \\
\text { COATE }\end{array}$ & $\begin{array}{l}\text { FIE } \\
\text { DEVEL } \\
\text { COETA }\end{array}$ & $\begin{array}{l}\text { CONT. } \\
\text { ADHIN } \\
\text { CogTE }\end{array}$ & $\begin{array}{l}\text { TOTAL } \\
\text { COGTB }\end{array}$ & $\begin{array}{l}\text { DISE. } \\
\text { TDTAL } \\
\text { COSTS }\end{array}$ \\
\hline YOTAL. & 22568 & 9356 & $\overline{123602}$ & $\overline{102072}$ & 3700 & 16200 & $\overparen{277570}$ & $\overrightarrow{242158}$ \\
\hline
\end{tabular}

- DeCOMMISSIONing COST

INITIAL PAYMENT = $84 / \mathrm{KgU}$ (INCLUDEB * $5 / \mathrm{KgU}$ IMPACT AID)

FINAL PAYMENT * 62 MgU (INCLUDES 9 G/KgU IMPACT AID) 
TABLE $\quad 99-14$

ESTIMATED SPENDINO SCHEDULE FOR STORAGE OF 30 GILOS ( 50 MTU) AT GOVERNMENT GITE WITHOUT EXISTINO FACILITIES

$(\$ 000,1989)$

\begin{tabular}{|c|c|c|c|c|c|c|c|c|}
\hline YEAR & $\begin{array}{l}\text { TRANS } \\
\text { FACIL } \\
\text { CDETS }\end{array}$ & $\begin{array}{l}\text { STOR } \\
\text { AREA } \\
\text { COSTS }\end{array}$ & $\begin{array}{r}\text { MODULE } \\
\text { COSTS }\end{array}$ & $\begin{array}{r}\text { OPERAT } \\
\text { COSTE }\end{array}$ & $\begin{array}{l}\text { FIs } \\
\text { DEVEL } \\
\text { Costa }\end{array}$ & $\begin{array}{l}\text { GOVT, } \\
\text { ADHIN } \\
\text { COSTS }\end{array}$ & $\begin{array}{l}\text { TOTAL } \\
\text { COSTs }\end{array}$ & $\begin{array}{l}\text { DISC. } \\
\text { TOTAL } \\
\text { COSTS }\end{array}$ \\
\hline $\begin{array}{l}1999 \\
1990 \\
1991 \\
1992 \\
1993 \\
1994 \\
1995 \\
1996 \\
1997 \\
1998 \\
1999 \\
2000 \\
2001 \\
2002 \\
2003 \\
2004 \\
2005 \\
2006\end{array}$ & $\begin{array}{r}3655 \\
249 \\
9398 \\
9273\end{array}$ & $\begin{array}{r}1534 \\
155 \\
489 \\
412\end{array}$ & $\begin{array}{r}635 \\
1269 \\
1269 \\
635\end{array}$ & $\begin{array}{l}992 \\
1994 \\
1984 \\
1943 \\
1901 \\
1901 \\
1901 \\
1901 \\
1901 \\
1901 \\
1901 \\
1984 \\
1984 \\
1994 \\
57958\end{array}$ & $\begin{array}{r}630 \\
1260 \\
1260 \\
430\end{array}$ & $\begin{array}{l}136 \\
136 \\
136 \\
136 \\
136 \\
136 \\
136 \\
136 \\
136 \\
136 \\
136 \\
136 \\
136 \\
136 \\
136 \\
136 \\
136 \\
136\end{array}$ & $\begin{array}{r}5955 \\
1800 \\
11263 \\
12078 \\
3389 \\
3389 \\
2714 \\
2037 \\
2037 \\
2037 \\
2037 \\
2037 \\
2037 \\
2037 \\
2120 \\
2120 \\
2120 \\
5931\end{array}$ & $\begin{array}{r}5755 \\
1765 \\
10845 \\
11381 \\
3131 \\
3070 \\
2410 \\
1773 \\
1739 \\
1704 \\
1671 \\
1638 \\
1606 \\
1575 \\
1607 \\
1575 \\
1544 \\
4236\end{array}$ \\
\hline TOTAL & 22575 & 2590 & 3808 & 31957 & $\overline{3780}$ & 2448 & 67158 & 59225 \\
\hline
\end{tabular}

- Decommissioning cost

INITIAL PAYMENT = $642 * / \mathrm{KgU}$ (INCLUDES $\$ / \mathrm{KgU}$ IMPACT AID)

FINAL PAYMENT $=609$ KaU (INCLUDES $10 / \mathrm{KgU}$ IMPACT AID)

TABLE A9-15

ESTIMATED SPENDING SCHEDULE FOR STORAGE DF 59 SILOS ( 100 MTU) AT GOVERNMENT SITE HITHOUT EXISTING FACILITIES $(\$ 000,1909)$

\begin{tabular}{|c|c|c|c|c|c|c|c|c|}
\hline YEAR & $\begin{array}{l}\text { TRANG } \\
\text { FACIL } \\
\text { COSTS }\end{array}$ & $\begin{array}{l}\text { STOR } \\
\text { AREA } \\
\text { COSTS }\end{array}$ & $\begin{array}{l}\text { MODULE } \\
\text { COSTS }\end{array}$ & $\begin{array}{r}\text { OPERAT } \\
\text { COSYG }\end{array}$ & $\begin{array}{l}\text { FIS } \\
\text { DEVEL } \\
\text { COSTS }\end{array}$ & $\begin{array}{l}\text { GOVT. } \\
\text { ADHIN } \\
\text { COSTS }\end{array}$ & $\begin{array}{l}\text { TOTAL } \\
\text { COSTS }\end{array}$ & $\begin{array}{l}\text { DISC. } \\
\text { TOTAL } \\
\text { CDSTS }\end{array}$ \\
\hline $\begin{array}{l}1989 \\
1990 \\
1991 \\
1992 \\
1993 \\
1994 \\
1995 \\
1996 \\
1997 \\
1998 \\
1999 \\
2000 \\
2001 \\
2002 \\
2003 \\
2004 \\
2005 \\
2006\end{array}$ & $\begin{array}{r}3653 \\
249 \\
9396 \\
9273\end{array}$ & $\begin{array}{r}1559 \\
155 \\
569 \\
491\end{array}$ & $\begin{array}{l}1251 \\
2502 \\
2502 \\
1251\end{array}$ & $\begin{array}{l}1051 \\
2101 \\
2101 \\
2012 \\
1922 \\
1922 \\
1922 \\
1922 \\
1922 \\
1922 \\
1922 \\
2101 \\
2101 \\
2101 \\
65714\end{array}$ & $\begin{array}{r}630 \\
1260 \\
1260 \\
630\end{array}$ & $\begin{array}{l}230 \\
230 \\
230 \\
230 \\
230 \\
230 \\
230 \\
230 \\
230 \\
230 \\
230 \\
230 \\
230 \\
230 \\
230 \\
230 \\
230 \\
230\end{array}$ & $\begin{array}{r}6073 \\
1894 \\
11457 \\
12926 \\
4833 \\
4833 \\
3493 \\
2152 \\
2152 \\
2152 \\
2152 \\
2152 \\
2152 \\
2152 \\
2331 \\
2331 \\
2331 \\
6801\end{array}$ & $\begin{array}{r}6073 \\
1857 \\
11012 \\
12180 \\
4465 \\
4377 \\
3102 \\
1873 \\
1837 \\
1901 \\
1765 \\
1731 \\
1697 \\
1664 \\
1767 \\
1732 \\
1698 \\
4837\end{array}$ \\
\hline TOTAL & & & & & 3780 & 4140 & 74367 & 65480 \\
\hline
\end{tabular}

- DECOMMISSIONING COST

INITIAL PAYMENT = 362 * KQU (INCLUDES * 5/KgU IMPACT AID)

FINAL PAYMENY a 333 KGU (INCLUDES * $10 / \mathrm{KgU}$ IMPACT AID) 
TABLE A9-16

ESTIMATED SPENDING SCHEDURE FOR GTORAOE OF 177 SILOS ( $300 \mathrm{MTU}$ ) AT GOVEFNMENT GITE WITHOUT EXISTINO FACILITIES

$(1000,1989)$

\begin{tabular}{|c|c|c|c|c|c|c|c|c|}
\hline YEAR & $\begin{array}{l}\text { TRANS } \\
\text { FACIL } \\
\text { COSTS }\end{array}$ & $\begin{array}{l}\text { STOR } \\
\text { AREA } \\
\text { COSTS }\end{array}$ & $\begin{array}{l}\text { MODULE } \\
\text { Costa }\end{array}$ & $\begin{array}{r}\text { OPERAT } \\
\text { COSTE }\end{array}$ & $\begin{array}{l}\text { FIS } \\
\text { DEVEL } \\
\text { COSTB }\end{array}$ & $\begin{array}{l}\text { GOVT, } \\
\text { ADMIN } \\
\text { COSTB }\end{array}$ & $\begin{array}{l}\text { TOTAL } \\
\text { CostB }\end{array}$ & $\begin{array}{l}\text { DISC. } \\
\text { roTAL } \\
\text { COSTS }\end{array}$ \\
\hline $\begin{array}{l}1909 \\
1990 \\
1991 \\
1992 \\
1993 \\
1994 \\
1995 \\
1996 \\
1997 \\
1999 \\
1999 \\
2000 \\
2001 \\
2002 \\
2003 \\
2004 \\
2005 \\
2006\end{array}$ & $\begin{array}{r}3653 \\
249 \\
9398 \\
9273\end{array}$ & $\begin{array}{r}1644 \\
155 \\
656 \\
779\end{array}$ & $\begin{array}{l}3753 \\
7505 \\
7505 \\
3753\end{array}$ & $\begin{array}{l}1230 \\
2459 \\
2457 \\
2233 \\
2007 \\
2007 \\
2007 \\
2007 \\
2007 \\
2007 \\
2007 \\
2459 \\
2457 \\
2459 \\
97058\end{array}$ & $\begin{array}{r}630 \\
1260 \\
1260 \\
630\end{array}$ & $\begin{array}{l}\mathbf{3 5 5} \\
\mathbf{3 5 5} \\
355 \\
355 \\
355 \\
\mathbf{3 5 5} \\
355 \\
355 \\
355 \\
355 \\
355 \\
355 \\
355 \\
355 \\
355 \\
355 \\
355 \\
355\end{array}$ & $\begin{array}{r}6284 \\
2019 \\
11669 \\
16020 \\
10319 \\
10319 \\
6341 \\
2362 \\
2362 \\
2362 \\
2362 \\
2362 \\
2362 \\
2362 \\
2814 \\
2814 \\
2814 \\
10050\end{array}$ & $\begin{array}{r}6294 \\
1979 \\
11400 \\
13096 \\
9533 \\
9346 \\
5631 \\
2056 \\
2016 \\
1976 \\
1938 \\
1900 \\
1862 \\
1826 \\
2133 \\
2091 \\
2050 \\
7184\end{array}$ \\
\hline TOTAL & 22575 & 3434 & 22516 & $\overline{39512}$ & 3780 & 6390 & 90207 & 86309 \\
\hline
\end{tabular}

- Decommissioning cost

INITIAL PAYMENT = $173 \$ \mathrm{KgU}$ (INCLUDEg $\$ 3 / \mathrm{KgU}$ IMPACT AID)

FINAL PAYMENT = $140 \mathrm{Kg}$ (INCLUDES $10 / \mathrm{KgU}$ IMPACT AID)

TABLE A9-17

ESTIMATED SPENDING SCHEDULE FOR GTORAGE OF 471 SILOS ( 900 MTU) AT GOVERNMENT SITE HITHOUT EXIETING FACILITIES

$(\$ 000,1989)$

\begin{tabular}{|c|c|c|c|c|c|c|c|c|}
\hline YEAR & $\begin{array}{l}\text { TRANS } \\
\text { FACIL } \\
\text { COSTS }\end{array}$ & $\begin{array}{l}\text { STOR } \\
\text { AREA } \\
\text { COSTS }\end{array}$ & $\begin{array}{l}\text { MODURE } \\
\text { COSTB }\end{array}$ & $\begin{array}{r}\text { OPERAT } \\
\text { COSTS }\end{array}$ & $\begin{array}{l}\text { FIS } \\
\text { DEVEL } \\
\text { COSTS }\end{array}$ & $\begin{array}{l}\text { GOVT, } \\
\text { ADHIN } \\
\text { COSTS }\end{array}$ & $\begin{array}{l}\text { TOTAL } \\
\text { COSTS }\end{array}$ & $\begin{array}{l}\text { DISC. } \\
\text { TOTAL } \\
\text { COSTS }\end{array}$ \\
\hline $\begin{array}{l}1909 \\
1990 \\
1991 \\
1992 \\
1993 \\
1994 \\
1995 \\
1996 \\
1997 \\
1990 \\
1999 \\
2000 \\
2001 \\
2002 \\
2003 \\
2004 \\
2005 \\
2006\end{array}$ & $\begin{array}{r}3653 \\
249 \\
9398 \\
9273\end{array}$ & $\begin{array}{r}1842 \\
155 \\
1515 \\
1439\end{array}$ & $\begin{array}{r}9989 \\
19979 \\
19979 \\
9989\end{array}$ & $\begin{array}{l}1867 \\
3733 \\
3733 \\
3102 \\
2470 \\
2470 \\
2470 \\
2470 \\
2470 \\
2470 \\
2470 \\
3733 \\
3733 \\
3733 \\
17492\end{array}$ & $\begin{array}{r}630 \\
1260 \\
1260 \\
630\end{array}$ & $\begin{array}{l}563 \\
563 \\
563 \\
563 \\
563 \\
563 \\
563 \\
563 \\
563 \\
563 \\
563 \\
563 \\
563 \\
563 \\
563 \\
563 \\
563 \\
563\end{array}$ & $\begin{array}{r}6690 \\
2227 \\
12736 \\
23760 \\
24275 \\
24275 \\
13654 \\
3035 \\
3033 \\
3033 \\
3033 \\
3033 \\
3033 \\
3033 \\
4296 \\
4296 \\
4296 \\
18055\end{array}$ & $\begin{array}{r}6690 \\
2183 \\
12241 \\
22390 \\
22426 \\
21987 \\
12124 \\
2640 \\
2589 \\
2938 \\
2488 \\
2439 \\
2392 \\
2345 \\
3256 \\
3192 \\
3129 \\
12994\end{array}$ \\
\hline & 22575 & 4950 & 59936 & 58416 & 3780 & 10134 & 159791 & 139943 \\
\hline
\end{tabular}

* - decommissioning COST

INITIAL PAYMENT = $114 / \mathrm{KgU}$ (INCLUDES $5 / \mathrm{KgU}$ IMPACT AID)

FINAL PAYMENT = $B 2$ \$KgU (INCLUDES $10 / \mathrm{KgU}$ IMPACT AID) 
TABLE A9-10

ESTIMATED GPENDING SCHEDIRE FOR GTORAGE OF 884 SILOS (1500 MTU) AT GOUERNMENT SITE WITHOUT EXISTINB FACILITIES

$(\$ 000,1909)$

\begin{tabular}{|c|c|c|c|c|c|c|c|c|}
\hline YEAR & $\begin{array}{l}\text { TRANS } \\
\text { FACIL } \\
\text { COSTS }\end{array}$ & $\begin{array}{l}\text { STOR } \\
\text { AREA } \\
\text { COSTB }\end{array}$ & $\begin{array}{r}\text { MODULE } \\
\text { COSTS }\end{array}$ & $\begin{array}{r}\text { OPERAT } \\
\text { COSTB }\end{array}$ & $\begin{array}{l}\text { FIB } \\
\text { DEVEL } \\
\text { COSTS }\end{array}$ & $\begin{array}{l}\text { GOVT. } \\
\text { ADHIN } \\
\text { COSTB }\end{array}$ & $\begin{array}{l}\text { TOTAK } \\
\text { COSTA }\end{array}$ & $\begin{array}{l}\text { DISC. } \\
\text { TOTAL } \\
\text { COSTS }\end{array}$ \\
\hline $\begin{array}{l}1989 \\
1990 \\
1991 \\
1992 \\
1993 \\
1994 \\
1993 \\
1996 \\
1997 \\
1999 \\
1999 \\
2000 \\
2001 \\
2002 \\
2003 \\
2004 \\
2005 \\
2006\end{array}$ & $\begin{array}{r}3655 \\
249 \\
9398 \\
9273\end{array}$ & $\begin{array}{r}2100 \\
155 \\
2402 \\
2325\end{array}$ & $\begin{array}{l}18745 \\
37490 \\
37490 \\
18743\end{array}$ & $\begin{array}{c}2566 \\
5131 \\
5131 \\
4030 \\
2928 \\
2928 \\
2928 \\
2928 \\
2928 \\
2928 \\
2928 \\
5131 \\
5131 \\
5131 \\
284071\end{array}$ & $\begin{array}{r}630 \\
1260 \\
1260 \\
630\end{array}$ & $\begin{array}{l}789 \\
789 \\
789 \\
789 \\
789 \\
789 \\
769 \\
789 \\
789 \\
789 \\
789 \\
789 \\
789 \\
789 \\
789 \\
789 \\
789 \\
769\end{array}$ & $\begin{array}{r}7182 \\
2453 \\
13849 \\
34328 \\
43410 \\
43410 \\
23564 \\
3717 \\
3717 \\
3717 \\
3717 \\
3717 \\
3717 \\
3717 \\
3920 \\
5920 \\
5920 \\
29196\end{array}$ & $\begin{array}{r}7162 \\
2405 \\
13311 \\
32348 \\
40104 \\
39319 \\
20924 \\
3236 \\
3172 \\
3110 \\
3049 \\
2989 \\
2931 \\
2873 \\
4487 \\
4399 \\
4312 \\
20851\end{array}$ \\
\hline TOTAL & 22575 & 6990 & $\overline{112470}$ & 01134 & 3780 & 14202 & $\overline{241171}$ & 211001 \\
\hline
\end{tabular}

- Decommissioning cost

INITIAL PAYMENT - $97 \% / \mathrm{KU}$ (INCLUDES * 5/KgU IMPACT AID)

FINAL PAYMENT = 63 KgU (INCLUDES * 10/KgU IMPACT AID)

TABLE 19-19

ESTIMATED EPENDING SCHEDULE FOR 8TORABE OF 1120 OILOS ( 1900 MTU)

AT GOUERNMENT GITE WITHOUT EXIBTING FACILITIES

$(\$ 000,1909)$

\begin{tabular}{|c|c|c|c|c|c|c|c|c|}
\hline YEAR & $\begin{array}{l}\text { TRANS } \\
\text { FACIL } \\
\text { COSTB }\end{array}$ & $\begin{array}{l}\text { gTOR } \\
\text { AREA } \\
\text { COSTS }\end{array}$ & $\begin{array}{r}\text { MODLLE } \\
\text { COSTE }\end{array}$ & $\begin{array}{r}\text { OPERAT } \\
\text { COBTS }\end{array}$ & $\begin{array}{l}\text { FIg } \\
\text { DEVaL } \\
\text { COSTB }\end{array}$ & $\begin{array}{l}\text { GOVT. } \\
\text { AOHIN } \\
\text { COSTB }\end{array}$ & $\begin{array}{l}\text { TOTAL } \\
\text { COSTE }\end{array}$ & $\begin{array}{l}\text { DISC. } \\
\text { TOTAL } \\
\text { COSTE }\end{array}$ \\
\hline $\begin{array}{l}1999 \\
1990 \\
1991 \\
1992 \\
1993 \\
1994 \\
1995 \\
1996 \\
1997 \\
1990 \\
1999 \\
2000 \\
2001 \\
2002 \\
2003 \\
2004 \\
2005 \\
2006\end{array}$ & $\begin{array}{r}3659 \\
249 \\
9399 \\
9273\end{array}$ & $\begin{array}{r}2230 \\
135 \\
2900 \\
2923\end{array}$ & $\begin{array}{l}23748 \\
47497 \\
47497 \\
23748\end{array}$ & $\begin{array}{c}2966 \\
5931 \\
5931 \\
4562 \\
3192 \\
3192 \\
3192 \\
3192 \\
3192 \\
3192 \\
3192 \\
3931 \\
5931 \\
5931 \\
346401\end{array}$ & $\begin{array}{r}630 \\
1260 \\
1260 \\
630\end{array}$ & $\begin{array}{l}900 \\
900 \\
900 \\
900 \\
900 \\
900 \\
900 \\
900 \\
900 \\
900 \\
900 \\
900 \\
900 \\
900 \\
900 \\
900 \\
900 \\
900\end{array}$ & $\begin{array}{r}7443 \\
2564 \\
14458 \\
40340 \\
54320 \\
54320 \\
29210 \\
4092 \\
4092 \\
4092 \\
4092 \\
4092 \\
4092 \\
4092 \\
6831 \\
6831 \\
6031 \\
35340\end{array}$ & $\begin{array}{r}744 J \\
2514 \\
13997 \\
39013 \\
30191 \\
49207 \\
25938 \\
3362 \\
3492 \\
3424 \\
3557 \\
3291 \\
3227 \\
3163 \\
3177 \\
5076 \\
4976 \\
25381\end{array}$ \\
\hline TORAL & 22575 & 8136 & 142490 & 94167 & 3780 & 16200 & $\overline{207349}$ & 251329 \\
\hline
\end{tabular}

- decomisistonina cost

INITIAL PAYMENT * 9J */KgL (INCLUDES * 5/KgU IMPACT AID)

FINAL PAYMENT = 59 KGU (INCLUDEg 10/KgU IMPACT AID) 
TABLE A9-20

ESTIMATED SPENDING SCHEDULE FOR STORAGE OF 5 CASKS ( SO HTU) AT GOVEFIMENT SITE WITH EXISTING FACILIYIES $(\$ 000,1989)$

\begin{tabular}{|c|c|c|c|c|c|c|c|c|}
\hline YEAR & $\begin{array}{l}\text { TRANS } \\
\text { FACIL } \\
\text { COSTS }\end{array}$ & $\begin{array}{l}\text { BTOR } \\
\text { AREA } \\
\text { COSTS }\end{array}$ & $\begin{array}{r}\text { MODULE } \\
\text { COSTA }\end{array}$ & $\begin{array}{r}\text { OPERAT } \\
\text { COSTE }\end{array}$ & $\begin{array}{l}\text { FIS } \\
\text { DEVEL } \\
\text { COSTS }\end{array}$ & $\begin{array}{l}\text { GOUT, } \\
\text { ADMIN } \\
\text { COSTB }\end{array}$ & $\begin{array}{l}\text { TOTAL } \\
\text { COSTS }\end{array}$ & $\begin{array}{l}\text { DISC. } \\
\text { TaTAL } \\
\text { COSTS }\end{array}$ \\
\hline $\begin{array}{l}1909 \\
1990 \\
1991 \\
1992 \\
1973 \\
1994 \\
1993 \\
1996 \\
1997 \\
1998 \\
1999 \\
2000 \\
2001 \\
2002 \\
2003 \\
2004 \\
2005 \\
2006\end{array}$ & $\begin{array}{l}666 \\
114 \\
947 \\
692\end{array}$ & $\begin{array}{r}1101 \\
145 \\
485 \\
413\end{array}$ & $\begin{array}{r}892 \\
1783 \\
1783 \\
892\end{array}$ & $\begin{array}{r}916 \\
1931 \\
1831 \\
1423 \\
1015 \\
1015 \\
1015 \\
1015 \\
1015 \\
1015 \\
1015 \\
1831 \\
1831 \\
1031 \\
20235\end{array}$ & $\begin{array}{r}630 \\
1260 \\
1260 \\
630\end{array}$ & $\begin{array}{l}136 \\
136 \\
136 \\
136 \\
136 \\
136 \\
136 \\
136 \\
136 \\
136 \\
136 \\
136 \\
136 \\
136 \\
136 \\
136 \\
136 \\
136\end{array}$ & $\begin{array}{l}2533 \\
1655 \\
2830 \\
3979 \\
3750 \\
3750 \\
2451 \\
1151 \\
1151 \\
1131 \\
1151 \\
1151 \\
1151 \\
1151 \\
1967 \\
1967 \\
1967 \\
2159\end{array}$ & $\begin{array}{r}2533 \\
1623 \\
2720 \\
3653 \\
3464 \\
3396 \\
2176 \\
1002 \\
982 \\
963 \\
944 \\
926 \\
908 \\
990 \\
1491 \\
1462 \\
1433 \\
1542\end{array}$ \\
\hline TOTAL & 2621 & 2144 & 5350 & 20622 & 3760 & 2448 & 36963 & 32110 \\
\hline
\end{tabular}

* - decommissioning cost

INITIAL PAYMENT - 277 * $/ \mathrm{KUU}$ (INCLUDES $3 / \mathrm{KgU}$ IMPACT AID)

FINAL PAYMENT = 414 kgU (INCLLDES 10/KgU IMPACT AID)

IABLE A9-21

ESTIMATED SPENDING SCHEDLZE FOR STORAGE OF 10 CASXS ( $100 \mathrm{MTU}$ ) AT GOVERNMENT BITE WITH EXISTING FACILITIES

$(\$ 000,1989)$

\begin{tabular}{|c|c|c|c|c|c|c|c|c|}
\hline YEAR & $\begin{array}{l}\text { TRANS } \\
\text { FAC IL } \\
\text { COSTS }\end{array}$ & $\begin{array}{l}\text { STOR } \\
\text { AREA } \\
\text { COSTS }\end{array}$ & $\begin{array}{r}\text { MODLRE } \\
\text { COSTS }\end{array}$ & $\begin{array}{c}\text { OPERAT } \\
\text { COSTS }\end{array}$ & $\begin{array}{l}\text { FIS } \\
\text { DEVEL } \\
\text { COSTA }\end{array}$ & $\begin{array}{l}\text { GOVT } \\
\text { ADHIN } \\
\text { COSTE }\end{array}$ & $\begin{array}{l}\text { TOTAL } \\
\text { COSTS }\end{array}$ & $\begin{array}{l}\text { DISC. } \\
\text { TOTAL } \\
\text { COSTS }\end{array}$ \\
\hline $\begin{array}{l}1999 \\
1990 \\
1991 \\
1992 \\
1993 \\
1994 \\
1995 \\
1996 \\
1997 \\
1999 \\
1999 \\
2000 \\
2001 \\
2002 \\
2003 \\
2004 \\
2005 \\
2008\end{array}$ & $\begin{array}{l}666 \\
114 \\
949 \\
092\end{array}$ & $\begin{array}{r}1106 \\
145 \\
902 \\
430\end{array}$ & $\begin{array}{l}1783 \\
3567 \\
3567 \\
1783\end{array}$ & $\begin{array}{l}952 \\
1904 \\
1904 \\
1474 \\
1044 \\
1044 \\
1044 \\
1044 \\
1044 \\
1044 \\
1044 \\
1904 \\
1904 \\
1904 \\
31014\end{array}$ & $\begin{array}{r}630 \\
1260 \\
1260 \\
630\end{array}$ & $\begin{array}{l}230 \\
230 \\
230 \\
230 \\
230 \\
230 \\
230 \\
230 \\
230 \\
230 \\
230 \\
230 \\
230 \\
230 \\
230 \\
230 \\
230 \\
230\end{array}$ & $\begin{array}{l}2632 \\
1749 \\
2941 \\
4917 \\
5701 \\
5701 \\
3497 \\
1274 \\
1274 \\
1274 \\
1274 \\
1274 \\
1274 \\
1274 \\
2134 \\
2134 \\
2134 \\
3331\end{array}$ & $\begin{array}{l}2632 \\
1713 \\
2827 \\
4633 \\
5267 \\
5164 \\
3096 \\
1109 \\
1087 \\
1066 \\
1045 \\
1025 \\
1003 \\
985 \\
1617 \\
1596 \\
1553 \\
2379\end{array}$ \\
\hline rOTAL, & 2621 & 2183 & 10700 & 22353 & 3780 & 4140 & 45779 & 39793 \\
\hline
\end{tabular}

- Decommissioning cost

INITIAL PAYMENT = $194 * / \mathrm{KgU}$ (INCLUDES $\$ 5 / \mathrm{KgU} \mathrm{IMPACT} \mathrm{AID)}$

FINAL PAYMENT * 239 KgU (INCLUDES $10 / \mathrm{KgU}$ IMPACT AID) 
TABLE A9-22

ESTIMATED SFENDING SCHEDURE FOR STORAGE OF 29 CASKS ( 300 MTU) AT GOVERNMENT SITE WITH EXISTING FACILITIES $(\$ 000,1989)$

\begin{tabular}{|c|c|c|c|c|c|c|c|c|}
\hline YEAR & $\begin{array}{l}\text { TRANS } \\
\text { FACIL } \\
\text { COSTS }\end{array}$ & $\begin{array}{l}\text { STOR } \\
\text { AREA } \\
\text { COSTS }\end{array}$ & $\begin{array}{r}\text { MODLLE } \\
\text { COSTB }\end{array}$ & $\begin{array}{r}\text { OPERAT } \\
\text { COBTS }\end{array}$ & $\begin{array}{l}\text { FIS } \\
\text { DEVEl } \\
\text { COSTS }\end{array}$ & $\begin{array}{l}\text { GOVT. } \\
\text { ADMIN } \\
\text { COSTS }\end{array}$ & $\begin{array}{l}\text { TOTAL } \\
\text { COSTS }\end{array}$ & $\begin{array}{l}\text { DISC. } \\
\text { TOTAL } \\
\text { COSTS }\end{array}$ \\
\hline $\begin{array}{l}1999 \\
1990 \\
1991 \\
1992 \\
1993 \\
1994 \\
1995 \\
1996 \\
1997 \\
1998 \\
1999 \\
2000 \\
2001 \\
2002 \\
2003 \\
2004 \\
2005 \\
2006\end{array}$ & $\begin{array}{l}666 \\
124 \\
949 \\
892\end{array}$ & $\begin{array}{r}1122 \\
145 \\
553 \\
461\end{array}$ & $\begin{array}{r}\$ 172 \\
10343 \\
10343 \\
\$ 172\end{array}$ & $\begin{array}{l}1093 \\
2186 \\
2186 \\
1673 \\
1160 \\
1160 \\
1160 \\
1160 \\
1160 \\
1160 \\
1160 \\
2186 \\
2186 \\
2186 \\
71900\end{array}$ & $\begin{array}{r}630 \\
1260 \\
1260 \\
630\end{array}$ & $\begin{array}{l}355 \\
355 \\
355 \\
355 \\
355 \\
355 \\
355 \\
355 \\
355 \\
355 \\
355 \\
355 \\
355 \\
355 \\
355 \\
355 \\
355 \\
355\end{array}$ & $\begin{array}{r}2773 \\
1874 \\
3117 \\
6623 \\
12894 \\
12684 \\
7200 \\
1515 \\
1515 \\
1515 \\
1515 \\
1315 \\
1315 \\
1515 \\
2541 \\
2541 \\
2541 \\
7945\end{array}$ & $\begin{array}{r}2773 \\
1837 \\
2996 \\
0126 \\
11903 \\
11669 \\
6393 \\
1319 \\
1293 \\
1269 \\
1243 \\
1218 \\
1195 \\
1171 \\
1926 \\
1898 \\
1951 \\
5390\end{array}$ \\
\hline TOTAL & 2621 & 2301 & 31030 & 29006 & 3780 & 6390 & 75128 & 65457 \\
\hline
\end{tabular}

- Decomissioning cost

INITIAL PAYMENT - $132 * / K g U$ (INCLUDES * 5/KgU IMPACT AID)

FINAL PAYMENT = 110 KQU (INCLUDES * 10/KgU IMPACT AID)

TABLE A9-23

ESTIMATED SPENDINQ SCHEDLRE FOR ETORAGE OF 76 CASKS ( 900 MTU) AT GOVERNAENT SITE WITH EXISTINO FACILITIES $(1000,1989)$

\begin{tabular}{|c|c|c|c|c|c|c|c|c|}
\hline YEAR & $\begin{array}{l}\text { JRANS } \\
\text { FACIL } \\
\text { COSTS }\end{array}$ & $\begin{array}{l}\text { STOR } \\
\text { AREA } \\
\text { COSTR }\end{array}$ & $\begin{array}{r}\text { MODLRE } \\
\text { COSTE }\end{array}$ & $\begin{array}{c}\text { OPERAT } \\
\text { COSTE }\end{array}$ & $\begin{array}{l}\text { FIS } \\
\text { DEVE } \\
\text { COSTA }\end{array}$ & $\begin{array}{l}\text { GOVT. } \\
\text { ADMIN } \\
\text { COSTS }\end{array}$ & $\begin{array}{l}\text { TOTAL } \\
\text { COSTA }\end{array}$ & $\begin{array}{l}\text { DISC. } \\
\text { TOTAL } \\
\text { COSTS }\end{array}$ \\
\hline $\begin{array}{l}1999 \\
1990 \\
1991 \\
1992 \\
1993 \\
1994 \\
1995 \\
1996 \\
1997 \\
1998 \\
1999 \\
2000 \\
2001 \\
2002 \\
2003 \\
2004 \\
2005 \\
2006\end{array}$ & $\begin{array}{l}666 \\
114 \\
949 \\
892\end{array}$ & $\begin{array}{r}1154 \\
145 \\
660 \\
587\end{array}$ & $\begin{array}{l}13553 \\
27107 \\
27107 \\
13553\end{array}$ & $\begin{array}{c}1511 \\
3021 \\
3021 \\
2233 \\
1444 \\
1444 \\
1444 \\
1444 \\
1444 \\
1444 \\
1444 \\
3021 \\
3021 \\
3021 \\
17297\end{array}$ & $\begin{array}{r}630 \\
1260 \\
1260 \\
630\end{array}$ & $\begin{array}{l}563 \\
563 \\
363 \\
363 \\
363 \\
563 \\
363 \\
563 \\
563 \\
563 \\
563 \\
563 \\
563 \\
563 \\
563 \\
563 \\
563 \\
563\end{array}$ & $\begin{array}{r}3013 \\
2002 \\
3432 \\
17736 \\
30691 \\
30691 \\
16349 \\
2007 \\
2007 \\
2007 \\
2007 \\
2007 \\
2007 \\
2007 \\
3584 \\
3584 \\
3584 \\
17860\end{array}$ & $\begin{array}{r}3013 \\
2041 \\
3299 \\
16713 \\
29354 \\
27799 \\
14517 \\
1747 \\
1713 \\
1679 \\
1646 \\
1614 \\
1593 \\
1551 \\
2716 \\
2663 \\
2611 \\
12755\end{array}$ \\
\hline TOTAL. & 2621 & 2546 & 81320 & 46254 & 3780 & 10134 & 146655 & 120013 \\
\hline
\end{tabular}

* Decomissioning cost

INITIAL PAYMENT = 111 *KGU (INCLUDES * 5/KgU IMPACT AID)

FINAL PAYMENT = 69 *KoU (INCLUDEg * 10/KgU IMPACT AID) 
TABLE A9-2C

ESTIMATED SPENDING SCHEDULE FOA QTORAGE OF 143 CASKg ( 1500 MTU) AT GOVERNMENT OITE WITH EXIBTINO FACILITIEG $(1000,1989)$

\begin{tabular}{|c|c|c|c|c|c|c|c|c|}
\hline YEAR & $\begin{array}{l}\text { TRANS } \\
\text { FACIL } \\
\text { COSTB }\end{array}$ & $\begin{array}{l}\text { BTOR } \\
\text { AREA } \\
\text { COBTA }\end{array}$ & $\begin{array}{l}\text { MODLRE } \\
\text { COsT3 }\end{array}$ & $\begin{array}{r}\text { OPERAT } \\
\text { COBTA }\end{array}$ & $\begin{array}{l}\text { F10 } \\
\text { DEVEL } \\
\text { COgTa }\end{array}$ & $\begin{array}{l}\text { GOVT, } \\
\text { ADHIN } \\
\text { COETS }\end{array}$ & $\begin{array}{l}\text { TOTAL, } \\
\text { COBTB }\end{array}$ & $\begin{array}{l}\text { DISC. } \\
\text { TOTAL } \\
\text { COSTS }\end{array}$ \\
\hline $\begin{array}{l}1909 \\
1990 \\
1991 \\
1992 \\
1993 \\
1994 \\
1995 \\
1996 \\
1997 \\
1998 \\
1999 \\
2000 \\
2001 \\
2002 \\
2003 \\
2004 \\
2005 \\
2006\end{array}$ & $\begin{array}{l}666 \\
114 \\
949 \\
892\end{array}$ & $\begin{array}{r}1196 \\
143 \\
900 \\
720\end{array}$ & $\begin{array}{l}25502 \\
51003 \\
51003 \\
25302\end{array}$ & $\begin{array}{c}2149 \\
4290 \\
4298 \\
3074 \\
1950 \\
1850 \\
1850 \\
1850 \\
1890 \\
1850 \\
1850 \\
4298 \\
4290 \\
4290 \\
31700\end{array}$ & $\begin{array}{r}630 \\
1260 \\
2260 \\
630\end{array}$ & $\begin{array}{l}789 \\
789 \\
769 \\
789 \\
789 \\
789 \\
769 \\
799 \\
789 \\
789 \\
789 \\
709 \\
709 \\
709 \\
769 \\
799 \\
709 \\
789\end{array}$ & $\begin{array}{r}3281 \\
2309 \\
3799 \\
30690 \\
36090 \\
36090 \\
29363 \\
2639 \\
2639 \\
2639 \\
2639 \\
2639 \\
2639 \\
2639 \\
5097 \\
5087 \\
3097 \\
32489\end{array}$ & $\begin{array}{r}3281 \\
2263 \\
3651 \\
29920 \\
51919 \\
50802 \\
26075 \\
2297 \\
2252 \\
2209 \\
2165 \\
2122 \\
2081 \\
2040 \\
3655 \\
3790 \\
3708 \\
23202\end{array}$ \\
\hline TOTAL & 2621 & 2069 & $\overline{153010}$ & 71363 & 3700 & 14202 & $\overline{247945}$ & 216519 \\
\hline
\end{tabular}

- Decommigsionino cost

INITIAL PAYHENT - 106 \$KOU (INCLUDEB $5 / K O U$ IMPACT AID)

FINAL PAYMENT $\rightarrow 57$ IKOU (INCLUDEG 10/KgU IMPACT AID)

TABLE A9-23

ESTIMATED SPENDING SCHEDULE FOR STOAAGE OF 101 CASKB ( 1900 MTU) AT GOVERNMENT BITE WITH EXISTINO FACILITIEG $(1000,1999)$

\begin{tabular}{|c|c|c|c|c|c|c|c|c|}
\hline YEAR & $\begin{array}{l}\text { TRANS } \\
\text { FACIL } \\
\text { COSTS }\end{array}$ & $\begin{array}{l}\text { STOR } \\
\text { AREA } \\
\text { COSTE }\end{array}$ & $\begin{array}{r}\text { MODULE } \\
\text { COgTE }\end{array}$ & $\begin{array}{r}\text { CPERAT } \\
\text { COBTA }\end{array}$ & $\begin{array}{l}\text { FIg } \\
\text { DEVER } \\
\text { COBTs }\end{array}$ & $\begin{array}{l}\text { OOVT, } \\
\text { ADMIN } \\
\text { COBTB }\end{array}$ & $\begin{array}{l}\text { TOTAL } \\
\text { COSTE }\end{array}$ & $\begin{array}{l}\text { DIGC. } \\
\text { JOTAL } \\
\text { COSTS }\end{array}$ \\
\hline $\begin{array}{l}1989 \\
1990 \\
1991 \\
1992 \\
1993 \\
1994 \\
1995 \\
1996 \\
1997 \\
1990 \\
1999 \\
2000 \\
2001 \\
2002 \\
2003 \\
2004 \\
2005 \\
2006\end{array}$ & $\begin{array}{l}686 \\
114 \\
949 \\
892\end{array}$ & $\begin{array}{r}1219 \\
145 \\
976 \\
804\end{array}$ & $\begin{array}{l}3227 \theta \\
64557 \\
64537 \\
32279\end{array}$ & $\begin{array}{c}2314 \\
5028 \\
5028 \\
3533 \\
2082 \\
2082 \\
2082 \\
2082 \\
2082 \\
2082 \\
2082 \\
502 \theta \\
5028 \\
3028 \\
39867\end{array}$ & $\begin{array}{r}630 \\
1260 \\
1260 \\
630\end{array}$ & $\begin{array}{l}900 \\
900 \\
900 \\
900 \\
900 \\
900 \\
900 \\
900 \\
900 \\
900 \\
900 \\
900 \\
900 \\
900 \\
900 \\
900 \\
900 \\
900\end{array}$ & $\begin{array}{r}3415 \\
2419 \\
3995 \\
38018 \\
70495 \\
70495 \\
36733 \\
2982 \\
2992 \\
2992 \\
2982 \\
2982 \\
2982 \\
2902 \\
5928 \\
3929 \\
5929 \\
40767\end{array}$ & $\begin{array}{r}3415 \\
2372 \\
3830 \\
33025 \\
63117 \\
63040 \\
32618 \\
2396 \\
2345 \\
2495 \\
2446 \\
2399 \\
2351 \\
2305 \\
4493 \\
4405 \\
4318 \\
29114\end{array}$ \\
\hline TOTAL & 2621 & 3044 & 193670 & 85650 & 3700 & 16200 & 304983 & 266493 \\
\hline
\end{tabular}

- Decomisisioning cost

INITIAL PAYMENT = 105 /KGU (INCLUDES $\$ / K g U$ IMPACT AID)

FINAL PAYMENT = 54 MgU (INCLUde日 $10 / \mathrm{KgU}$ IMPACt aID) 
TABLE $19-26$

ESTIMATED SPENDING SCHEDULE FOR BTORAGE OF 119 DRYWELLG ( 50 MTU) AT GOVERNMENT SITE WITH EXISTING FACILITIEO $(1000,1909)$

\begin{tabular}{|c|c|c|c|c|c|c|c|c|}
\hline YEAR & $\begin{array}{l}\text { TRANS } \\
\text { FAC IL } \\
\text { COSTB }\end{array}$ & $\begin{array}{l}\text { GTOR } \\
\text { AREA } \\
\text { COSTR }\end{array}$ & $\begin{array}{r}\text { MODURE } \\
\text { COSTA }\end{array}$ & $\begin{array}{r}\text { OPERAT } \\
\text { COSTE }\end{array}$ & $\begin{array}{l}\text { FIS } \\
\text { DEVEL } \\
\text { COSTB }\end{array}$ & $\begin{array}{l}\text { GOVT. } \\
\text { ADKIN } \\
\text { COSTS }\end{array}$ & $\begin{array}{l}\text { TOTAL } \\
\text { COSTS }\end{array}$ & $\begin{array}{l}\text { DISC, } \\
\text { TOTAL } \\
\text { COSTS }\end{array}$ \\
\hline $\begin{array}{l}1989 \\
1990 \\
1991 \\
1992 \\
1993 \\
1994 \\
1995 \\
1996 \\
1997 \\
1998 \\
1999 \\
2000 \\
2001 \\
2002 \\
2003 \\
2004 \\
2005 \\
2006\end{array}$ & $\begin{array}{r}1499 \\
114 \\
3723 \\
3666\end{array}$ & $\begin{array}{r}1813 \\
155 \\
2020 \\
1943\end{array}$ & $\begin{array}{r}543 \\
1086 \\
1086 \\
543\end{array}$ & $\begin{array}{l}1004 \\
2008 \\
2008 \\
1508 \\
1169 \\
1168 \\
1169 \\
1168 \\
1168 \\
1168 \\
1168 \\
2008 \\
2008 \\
2008 \\
3638\end{array}$ & $\begin{array}{r}630 \\
1260 \\
1260 \\
630\end{array}$ & $\begin{array}{l}136 \\
136 \\
136 \\
136 \\
136 \\
136 \\
136 \\
136 \\
136 \\
136 \\
136 \\
136 \\
136 \\
136 \\
136 \\
136 \\
136 \\
136\end{array}$ & $\begin{array}{l}1079 \\
1665 \\
7139 \\
7922 \\
3230 \\
3230 \\
2267 \\
1304 \\
1304 \\
1304 \\
1304 \\
1304 \\
1304 \\
1304 \\
2144 \\
2144 \\
2144 \\
3774\end{array}$ & $\begin{array}{l}4075 \\
1632 \\
6862 \\
7465 \\
2984 \\
2926 \\
2013 \\
1135 \\
1113 \\
1091 \\
1070 \\
1049 \\
1028 \\
1008 \\
1625 \\
1593 \\
1562 \\
2695\end{array}$ \\
\hline YOTAL & $900 \overline{2}$ & 5931 & 3258 & 24446 & 3780 & 2448 & 40665 & 42929 \\
\hline
\end{tabular}

- Decommissioning cost

INITIAL PAYHENT $=433 * / \mathrm{KgU}$ (INCLUDES $* 3 / \mathrm{KgU}$ IMPACT AID)

FINAL PAYMENT = 401 \$KgU (INCLUDES $10 / \mathrm{KgU}$ 1MPACT AID)

TA8LE A9-27

ESTIMATED SPENDING SCHEDULE FOR 9TORAGE OF 236 DRYWELLS ( 100 MTU) AT GOVERNHENT SITE WITH EXISTING FACILITIES

$(\$ 000,1909)$

\begin{tabular}{|c|c|c|c|c|c|c|c|c|}
\hline YEAR & $\begin{array}{l}\text { TRANS } \\
\text { FACIL } \\
\text { COSTS }\end{array}$ & $\begin{array}{l}\text { STOR } \\
\text { AREA } \\
\text { COSTS }\end{array}$ & $\begin{array}{l}\text { MODLRE } \\
\text { COSTE }\end{array}$ & $\begin{array}{r}\text { OPERAT } \\
\text { COSTB }\end{array}$ & $\begin{array}{l}\text { FIg } \\
\text { DEVEL } \\
\text { COSTS }\end{array}$ & $\begin{array}{l}\text { GOUT, } \\
\text { ADHIN } \\
\text { COSTE }\end{array}$ & $\begin{array}{l}\text { TOTAL } \\
\text { Costs }\end{array}$ & $\begin{array}{l}\text { DISC. } \\
\text { TOTAL } \\
\text { COSTS }\end{array}$ \\
\hline $\begin{array}{l}1999 \\
1990 \\
1991 \\
1992 \\
1993 \\
1994 \\
1993 \\
1996 \\
1997 \\
1998 \\
1999 \\
2000 \\
2001 \\
2002 \\
2003 \\
2004 \\
2005 \\
2006\end{array}$ & $\begin{array}{r}1499 \\
114 \\
3723 \\
3666\end{array}$ & $\begin{array}{r}1832 \\
155 \\
2003 \\
2005\end{array}$ & $\begin{array}{l}1086 \\
2171 \\
2171 \\
1086\end{array}$ & $\begin{array}{l}1073 \\
2145 \\
2145 \\
1667 \\
1188 \\
1189 \\
1189 \\
1199 \\
1188 \\
1189 \\
1199 \\
2145 \\
2145 \\
2145 \\
43184\end{array}$ & $\begin{array}{r}630 \\
1260 \\
1260 \\
630\end{array}$ & $\begin{array}{l}230 \\
230 \\
230 \\
230 \\
230 \\
230 \\
230 \\
230 \\
230 \\
230 \\
230 \\
230 \\
230 \\
230 \\
230 \\
230 \\
230 \\
230\end{array}$ & $\begin{array}{l}4191 \\
1759 \\
7296 \\
8690 \\
4546 \\
4546 \\
2983 \\
1418 \\
1418 \\
1418 \\
1418 \\
1418 \\
1418 \\
1418 \\
2375 \\
2375 \\
2375 \\
4549\end{array}$ & $\begin{array}{l}4191 \\
1725 \\
7013 \\
8169 \\
4200 \\
4117 \\
2649 \\
1234 \\
1210 \\
1187 \\
1163 \\
1140 \\
1118 \\
1096 \\
1900 \\
1765 \\
1730 \\
3248\end{array}$ \\
\hline TOTAL & 9002 & 6075 & 6514 & 26099 & 3780 & 4140 & $\overline{55610}$ & 48775 \\
\hline
\end{tabular}

- DECOMMISSIONING COST

INITIAL PAYMENT - 253 */KgU (INCLUDES $\$$ S/KgU IMPACT AID)

FINAL PAYMENT = 272 MKU (INCLUDES * 10/KGU IMPACT AID) 


\section{TABLE A9-28}

ESTIMATED SPENDING SCHEDULE FOR BTORAGE OF 707 DRYWELLS ( 300 MTU) AT GOVERNHENT SITE WITH EXISTING FACILITIES

$(\$ 000,1989)$

\begin{tabular}{|c|c|c|c|c|c|c|c|c|}
\hline YEAR & $\begin{array}{l}\text { TRANS } \\
\text { FACIL } \\
\text { COSTS }\end{array}$ & $\begin{array}{l}\text { STOR } \\
\text { AREA } \\
\text { COSTS }\end{array}$ & $\begin{array}{l}\text { HODULE } \\
\text { COSTS }\end{array}$ & $\begin{array}{r}\text { OPERAT } \\
\text { COSTS }\end{array}$ & $\begin{array}{l}\text { FIS } \\
\text { DEVEL } \\
\text { COSTG }\end{array}$ & $\begin{array}{l}\text { GOVT. } \\
\text { ADMIN } \\
\text { COSTS }\end{array}$ & $\begin{array}{l}\text { TOTAL } \\
\text { COSTS }\end{array}$ & $\begin{array}{l}\text { DISC. } \\
\text { TOTAL } \\
\text { COSTE }\end{array}$ \\
\hline $\begin{array}{l}1789 \\
1990 \\
1991 \\
1992 \\
1993 \\
1994 \\
1995 \\
1996 \\
1997 \\
1990 \\
1999 \\
2000 \\
2001 \\
2002 \\
2003 \\
2004 \\
2005 \\
2006\end{array}$ & $\begin{array}{r}1499 \\
114 \\
3723 \\
3666\end{array}$ & $\begin{array}{r}1893 \\
155 \\
2287 \\
2210\end{array}$ & $\begin{array}{l}3252 \\
6505 \\
6505 \\
3252\end{array}$ & $\begin{array}{l}1341 \\
2682 \\
2682 \\
1973 \\
1264 \\
1264 \\
1264 \\
1264 \\
1264 \\
1264 \\
1264 \\
2682 \\
2682 \\
2682 \\
7012\end{array}$ & $\begin{array}{r}630 \\
1260 \\
1260 \\
630\end{array}$ & $\begin{array}{l}355 \\
355 \\
355 \\
355 \\
355 \\
353 \\
355 \\
355 \\
355 \\
355 \\
355 \\
355 \\
355 \\
355 \\
355 \\
355 \\
355 \\
355\end{array}$ & $\begin{array}{r}4377 \\
1684 \\
7625 \\
11454 \\
9542 \\
9542 \\
5580 \\
1619 \\
1619 \\
1619 \\
1619 \\
1619 \\
1619 \\
1619 \\
3037 \\
3037 \\
3037 \\
7367\end{array}$ & $\begin{array}{r}4377 \\
1847 \\
7329 \\
10793 \\
8915 \\
9642 \\
4955 \\
1409 \\
1382 \\
1355 \\
1329 \\
1302 \\
1277 \\
1252 \\
2302 \\
2257 \\
2212 \\
5261\end{array}$ \\
\hline TOTAL & 9002 & 6545 & 19514 & 32584 & 3780 & 6390 & 77815 & 68095 \\
\hline
\end{tabular}

* - Decommissioning cost

INITIAL PAYMENT = 130 \% KQU (INCLUDES * 5/KOU IMPACT AID)

FJNAL PAYMENT - 121 KKOL (INCLUDES * 10/KgU IMPACT AID)

TABLE $A 9-29$

ESTIMATED SPENDING SCHEDULE FOR STORAGE OF 1996 DRYHELLS ( AT GOVERNMENT BITE WITH EXISTING FACILITIES $(\$ 000,1989)$

\begin{tabular}{|c|c|c|c|c|c|c|c|c|}
\hline YEAR & $\begin{array}{l}\text { TRANS } \\
\text { FACIL } \\
\text { CGSTS }\end{array}$ & $\begin{array}{l}\text { STOR } \\
\text { AREA } \\
\text { COSTB }\end{array}$ & $\begin{array}{l}\text { MODULE } \\
\text { COSTB }\end{array}$ & $\begin{array}{r}\text { OPERAT } \\
\text { COSTB }\end{array}$ & $\begin{array}{l}\text { FI8 } \\
\text { DEVEL } \\
\text { COST }\end{array}$ & $\begin{array}{l}\text { GOVT } \\
\text { ADHIN } \\
\text { COSTE }\end{array}$ & $\begin{array}{l}\text { TOTAL } \\
\text { COSTS }\end{array}$ & $\begin{array}{l}\text { DISC. } \\
\text { TOTAL } \\
\text { COSTS }\end{array}$ \\
\hline $\begin{array}{l}1989 \\
1990 \\
1991 \\
1992 \\
1993 \\
1994 \\
1995 \\
1996 \\
1997 \\
1998 \\
1999 \\
2000 \\
2001 \\
2002 \\
2003 \\
2004 \\
2005 \\
2006\end{array}$ & $\begin{array}{r}1499 \\
114 \\
3723 \\
3666\end{array}$ & $\begin{array}{r}2025 \\
155 \\
2726 \\
2648\end{array}$ & $\begin{array}{r}8676 \\
17352 \\
17352 \\
0676\end{array}$ & $\begin{array}{l}2076 \\
4152 \\
4152 \\
2001 \\
1449 \\
1449 \\
1449 \\
1449 \\
1449 \\
1449 \\
1449 \\
4152 \\
4152 \\
4152 \\
13722\end{array}$ & $\begin{array}{r}630 \\
1260 \\
1260 \\
630\end{array}$ & $\begin{array}{l}563 \\
563 \\
563 \\
563 \\
563 \\
563 \\
563 \\
563 \\
563 \\
563 \\
563 \\
363 \\
563 \\
563 \\
563 \\
563 \\
563 \\
563\end{array}$ & $\begin{array}{r}4717 \\
2092 \\
6272 \\
18259 \\
22067 \\
22067 \\
12040 \\
2012 \\
2012 \\
2012 \\
2012 \\
2012 \\
2012 \\
2012 \\
4715 \\
4715 \\
4715 \\
14285\end{array}$ & $\begin{array}{r}4717 \\
2051 \\
7951 \\
17206 \\
20387 \\
19987 \\
10691 \\
1752 \\
1717 \\
1694 \\
1651 \\
1619 \\
1596 \\
1555 \\
3573 \\
3503 \\
3435 \\
10202\end{array}$ \\
\hline TDTAL & 9002 & 7554 & 52056 & 49502 & 3790 & 10134 & $\overline{132028}$ & 115266 \\
\hline
\end{tabular}

* - decommissionimo cost

INITIAL PAYMENT $=91$ /KgL (INCLUDES $5 / \mathrm{KgL}$ IMPACT AID)

FINAL PAYMENT - 73 \$KgU (INCLUDES $10 / \mathrm{KgL}$ IMPACT AID) 
TABLE A9-30

ESTIMATED SPENDING SCHEDULE FOR STORAGE OF 3535 DRYWELLB ( 1500 MTU) AT GDVERNMENT SITE WITH EXISTING FACILITIES

(\$000, 1989)

\begin{tabular}{|c|c|c|c|c|c|c|c|c|}
\hline YEAR & $\begin{array}{l}\text { TRANS } \\
\text { FACIL } \\
\text { COSTA }\end{array}$ & $\begin{array}{l}\text { GTOR } \\
\text { AREA } \\
\text { COSTS }\end{array}$ & $\begin{array}{r}\text { MODLLE } \\
\text { COSTa }\end{array}$ & $\begin{array}{r}\text { DPERAT } \\
\text { COSTE }\end{array}$ & $\begin{array}{l}\text { FIS } \\
\text { DEVEL } \\
\text { Costa }\end{array}$ & $\begin{array}{l}\text { GOVT. } \\
\text { ADMIN } \\
\text { COST8 }\end{array}$ & $\begin{array}{l}\text { Total } \\
\text { Coste }\end{array}$ & $\begin{array}{l}\text { DISC, } \\
\text { TOTAL } \\
\text { COSTE }\end{array}$ \\
\hline $\begin{array}{l}1999 \\
1990 \\
1991 \\
1992 \\
1993 \\
1994 \\
1995 \\
1996 \\
1997 \\
1998 \\
1949 \\
2000 \\
2001 \\
2002 \\
2003 \\
2004 \\
2005 \\
2006\end{array}$ & $\begin{array}{r}1499 \\
114 \\
3723 \\
3666\end{array}$ & $\begin{array}{r}2194 \\
155 \\
3291 \\
3213\end{array}$ & $\begin{array}{l}16262 \\
32524 \\
32524 \\
16262\end{array}$ & $\begin{array}{l}3183 \\
6365 \\
6365 \\
4057 \\
1749 \\
1749 \\
1749 \\
1749 \\
1749 \\
1749 \\
1749 \\
6365 \\
6363 \\
6363 \\
230854\end{array}$ & $\begin{array}{r}630 \\
1260 \\
1260 \\
630\end{array}$ & $\begin{array}{l}789 \\
789 \\
789 \\
789 \\
789 \\
789 \\
789 \\
789 \\
789 \\
789 \\
789 \\
789 \\
789 \\
789 \\
789 \\
789 \\
789 \\
789\end{array}$ & $\begin{array}{r}5112 \\
2319 \\
9063 \\
27743 \\
39679 \\
39679 \\
21109 \\
2539 \\
2539 \\
2539 \\
2538 \\
2538 \\
2538 \\
2539 \\
7154 \\
7154 \\
7154 \\
23874\end{array}$ & $\begin{array}{r}5112 \\
2273 \\
9711 \\
26143 \\
36656 \\
35939 \\
10743 \\
2209 \\
2166 \\
2124 \\
2082 \\
2041 \\
2001 \\
1962 \\
5422 \\
5316 \\
5211 \\
17050\end{array}$ \\
\hline TOTAL & 9002 & 8853 & 97572 & 74393 & 3780 & $\overline{14202}$ & 207802 & 181160 \\
\hline
\end{tabular}

* - DECOMMISSIONING COST

INITIAL PAYMENT $=79 \% / \mathrm{KgU}$ (INCLUDES $4 / \mathrm{KgU}$ IMPACT AID)

FINAL PAYMENT = 59 KOU (INCLUDES $9 / \mathrm{KgU}$ IMPACT AID)

TABLE $A 9-31$

ESTIHATED SFENDING BCHEDLLE FDR 9TORAGE OF 4478 DRYWELLS (1900 KTU) AT OOVERNMENT BITE WITH EXISTINO FACILITIEG $(\$ 000,1909)$

\begin{tabular}{|c|c|c|c|c|c|c|c|c|}
\hline YEAR & $\begin{array}{l}\text { TRANG } \\
\text { FACIL } \\
\text { COSTE }\end{array}$ & $\begin{array}{l}\text { BTOR } \\
\text { AREA } \\
\text { COST8 }\end{array}$ & $\begin{array}{r}\text { MODULE } \\
\text { COSTa }\end{array}$ & $\begin{array}{r}\text { OPERAT } \\
\text { COSTE }\end{array}$ & $\begin{array}{l}\text { FI } \\
\text { DEVER } \\
\text { COSTg }\end{array}$ & $\begin{array}{l}\text { OOVT } \\
\text { ADHIN } \\
\text { COSTE }\end{array}$ & $\begin{array}{l}\text { TOTAL } \\
\text { COSTS }\end{array}$ & $\begin{array}{l}\text { DISC. } \\
\text { TOTAL } \\
\text { COSTS }\end{array}$ \\
\hline $\begin{array}{l}1999 \\
1990 \\
1991 \\
1992 \\
1993 \\
1994 \\
1993 \\
1996 \\
1997 \\
1998 \\
1999 \\
2000 \\
2001 \\
2002 \\
2003 \\
2004 \\
2003 \\
2006\end{array}$ & $\begin{array}{r}1499 \\
114 \\
3723 \\
3666\end{array}$ & $\begin{array}{l}2280 \\
153 \\
3603 \\
3525\end{array}$ & $\begin{array}{l}20600 \\
41201 \\
41201 \\
20600\end{array}$ & $\begin{array}{l}3815 \\
7630 \\
7630 \\
4776 \\
1922 \\
1922 \\
1922 \\
1922 \\
1922 \\
1922 \\
1922 \\
7630 \\
7630 \\
7630 \\
284354\end{array}$ & $\begin{array}{r}630 \\
1260 \\
\$ 260 \\
630\end{array}$ & $\begin{array}{l}900 \\
900 \\
900 \\
900 \\
900 \\
900 \\
900 \\
900 \\
900 \\
900 \\
900 \\
900 \\
900 \\
900 \\
900 \\
900 \\
900 \\
900\end{array}$ & $\begin{array}{r}3517 \\
2429 \\
9496 \\
33136 \\
49731 \\
49731 \\
26276 \\
2822 \\
2822 \\
2922 \\
2822 \\
2922 \\
2922 \\
2922 \\
8330 \\
9330 \\
8330 \\
29335\end{array}$ & $\begin{array}{r}5317 \\
2381 \\
9118 \\
31225 \\
43944 \\
13043 \\
23332 \\
2457 \\
2409 \\
2361 \\
2315 \\
2270 \\
2225 \\
2191 \\
6465 \\
6338 \\
6214 \\
20950\end{array}$ \\
\hline TOTAL & 9002 & 9571 & $\overline{123602}$ & 88630 & 3780 & 16200 & $\overline{250705}$ & $\overline{218545}$ \\
\hline
\end{tabular}

* - Decomhissioning cost

INITIAL PAYMENT = 76 \$KOU (INCLUDES $4 / \mathrm{KgU}$ IMPACT AID)

FINAL PAYMENT - S5 KKUU (INCLUDES $8 / \mathrm{KgU}$ IMPACT AID) 
IABLE A9-32

ESTIMATED SPENDING SCHEDULE FOR BTORAGE OF 30 SILOS ( 50 MTU) AT GOVERNMENT SITE WITH EXISTING FACILITIES (\$000. 1989)

\begin{tabular}{|c|c|c|c|c|c|c|c|c|}
\hline YEAR & $\begin{array}{l}\text { TRANS } \\
\text { FACIL } \\
\text { COSTS }\end{array}$ & $\begin{array}{l}\text { STOR } \\
\text { AREA } \\
\text { COSTS }\end{array}$ & $\begin{array}{l}\text { MaDULE } \\
\text { COSTE }\end{array}$ & $\begin{array}{r}\text { OPERAT } \\
\text { COSTS }\end{array}$ & $\begin{array}{l}\text { FIB } \\
\text { DEVEL } \\
\text { COSTB }\end{array}$ & $\begin{array}{l}\text { GOVT. } \\
\text { ADHIN } \\
\text { COSTB }\end{array}$ & $\begin{array}{l}\text { TOTAL } \\
\text { COSTB }\end{array}$ & $\begin{array}{l}\text { DISC. } \\
\text { TOTAL } \\
\text { COSTS }\end{array}$ \\
\hline $\begin{array}{l}1999 \\
1990 \\
1991 \\
1992 \\
1993 \\
1994 \\
1995 \\
1996 \\
1997 \\
1998 \\
1999 \\
2000 \\
2001 \\
2002 \\
2003 \\
2004 \\
2005 \\
2006\end{array}$ & $\begin{array}{r}1499 \\
114 \\
3726 \\
3669\end{array}$ & $\begin{array}{r}1562 \\
155 \\
583 \\
505\end{array}$ & $\begin{array}{r}635 \\
1269 \\
1269 \\
635\end{array}$ & $\begin{array}{l}990 \\
1915 \\
1915 \\
1911 \\
1107 \\
1107 \\
1107 \\
1107 \\
1107 \\
1107 \\
1107 \\
1915 \\
1915 \\
1915 \\
31244\end{array}$ & $\begin{array}{r}630 \\
1260 \\
1260 \\
630\end{array}$ & $\begin{array}{l}136 \\
136 \\
136 \\
136 \\
136 \\
136 \\
136 \\
136 \\
136 \\
136 \\
136 \\
136 \\
136 \\
136 \\
136 \\
136 \\
136 \\
136\end{array}$ & $\begin{array}{l}3027 \\
1665 \\
5705 \\
6533 \\
3320 \\
3320 \\
2282 \\
1243 \\
1243 \\
1243 \\
1243 \\
1243 \\
1243 \\
1243 \\
2051 \\
2051 \\
2051 \\
3240\end{array}$ & $\begin{array}{r}3027 \\
1632 \\
3483 \\
6156 \\
3067 \\
3007 \\
2026 \\
1082 \\
1061 \\
1040 \\
1020 \\
1000 \\
980 \\
961 \\
1554 \\
1524 \\
1494 \\
2328\end{array}$ \\
\hline TOTAL & 9000 & 2805 & 3808 & 22917 & 3780 & 2448 & 44766 & 39242 \\
\hline
\end{tabular}

- DECDMMISSIONING COST

INITIAL PAYMENT = $384 \$ / K 0 U$ (INCLUDES $3 / \mathrm{KgU}$ IMPACT AID)

FINAL PAYMENT $=434$ KQU (INCLUDES $10 / \mathrm{KgU}$ IMPACT AID)

IABLE A9-33

ESTIMATED SPENDING SCHEDLLE FOR BTORAGE OF 59 SILOS ( 100 MTU) AT GOVERNMENT SITE WITH EXISTING FACILITIES

$(\$ 000,1989)$

\begin{tabular}{|c|c|c|c|c|c|c|c|c|}
\hline YEAR & $\begin{array}{l}\text { TRANS } \\
\text { FACIL } \\
\text { COSTS }\end{array}$ & $\begin{array}{l}\text { STOR } \\
\text { AREA } \\
\text { COSTg }\end{array}$ & $\begin{array}{l}\text { MUDULE } \\
\text { CDSTB }\end{array}$ & $\begin{array}{r}\text { OPERAT } \\
\text { COSTE }\end{array}$ & $\begin{array}{l}\text { FI } 8 \\
\text { DEVEL } \\
\text { COST } 8\end{array}$ & $\begin{array}{l}\text { GOVT. } \\
\text { ADHIN } \\
\text { COSTS }\end{array}$ & $\begin{array}{l}\text { TOTAL } \\
\text { COSTS }\end{array}$ & $\begin{array}{l}\text { DISC. } \\
\text { TOTAL. } \\
\text { COSTS }\end{array}$ \\
\hline $\begin{array}{l}1989 \\
1990 \\
1991 \\
1992 \\
1993 \\
1994 \\
1995 \\
1996 \\
1997 \\
1998 \\
1999 \\
2000 \\
2001 \\
2002 \\
2003 \\
2004 \\
2005 \\
2006\end{array}$ & $\begin{array}{r}1499 \\
114 \\
3726 \\
3669\end{array}$ & $\begin{array}{r}1586 \\
153 \\
642 \\
585\end{array}$ & $\begin{array}{l}1251 \\
2502 \\
2502 \\
1251\end{array}$ & $\begin{array}{l}1016 \\
2031 \\
2031 \\
1392 \\
1132 \\
1132 \\
1132 \\
1132 \\
1132 \\
1132 \\
1132 \\
2031 \\
2031 \\
2031 \\
3900\end{array}$ & $\begin{array}{r}630 \\
1260 \\
1260 \\
630\end{array}$ & $\begin{array}{l}230 \\
230 \\
230 \\
230 \\
230 \\
230 \\
230 \\
230 \\
230 \\
230 \\
230 \\
230 \\
230 \\
230 \\
230 \\
230 \\
230 \\
230\end{array}$ & $\begin{array}{l}3945 \\
1759 \\
3879 \\
7361 \\
4763 \\
4763 \\
3063 \\
1362 \\
1362 \\
1362 \\
1362 \\
1362 \\
1362 \\
1362 \\
2261 \\
2261 \\
2261 \\
4130\end{array}$ & $\begin{array}{l}3945 \\
1725 \\
5650 \\
6955 \\
1400 \\
4314 \\
2720 \\
1186 \\
1162 \\
1140 \\
1117 \\
1095 \\
1074 \\
1053 \\
1714 \\
1680 \\
1647 \\
2949\end{array}$ \\
\hline TOTAL & 9000 & 2908 & $7 \overline{7506}$ & 24577 & 3780 & 4140 & 31979 & 45526 \\
\hline
\end{tabular}

* - DECOMMISSIONING COST

IN1TIAL PAYMENT = $233 * / K g U$ (INCLUDES * $5 / \mathrm{KgU}$ IMPACT AID)

FINAL PAYMENT = 250 \$KQU (INCLUDES * 10/KOU IMPACT AID) 
IABLE A9-34

ESTIMATED SPENDINO SCHEDULE FOR STORAGE DF 177 SILOS ( 300 MTU) AT GOVERNMENT SITE WITH EXIETING FACILITIES

(\$000, 1989)

\begin{tabular}{|c|c|c|c|c|c|c|c|c|}
\hline YEAR & $\begin{array}{l}\text { TRANG } \\
\text { FACIL } \\
\text { COSTR }\end{array}$ & $\begin{array}{l}\text { STOR } \\
\text { AREA } \\
\text { COSTS }\end{array}$ & $\begin{array}{l}\text { MODULE } \\
\text { COSTB }\end{array}$ & $\begin{array}{r}\text { OPERAT } \\
\text { COSTE }\end{array}$ & $\begin{array}{l}\text { FIS } \\
\text { DEVEL. } \\
\text { COSTS }\end{array}$ & $\begin{array}{l}\text { GONT, } \\
\text { ADHIN } \\
\text { COSTS }\end{array}$ & $\begin{array}{l}\text { TOTAL } \\
\text { COSTS }\end{array}$ & $\begin{array}{l}\text { DISC, } \\
\text { TOTAL } \\
\text { COSTS }\end{array}$ \\
\hline $\begin{array}{l}1989 \\
1990 \\
1991 \\
1992 \\
1993 \\
1994 \\
1995 \\
1996 \\
1997 \\
1998 \\
1999 \\
2000 \\
2001 \\
2002 \\
2003 \\
2004 \\
2005 \\
2008\end{array}$ & $\begin{array}{r}1499 \\
114 \\
3726 \\
3669\end{array}$ & $\begin{array}{r}1673 \\
155 \\
950 \\
872\end{array}$ & $\begin{array}{c}3753 \\
7505 \\
7505 \\
3753 \\
.\end{array}$ & $\begin{array}{l}1195 \\
2309 \\
2309 \\
1803 \\
1216 \\
1216 \\
1216 \\
1216 \\
1216 \\
1216 \\
1216 \\
2389 \\
2389 \\
2389 \\
70354\end{array}$ & $\begin{array}{r}630 \\
1260 \\
1260 \\
630\end{array}$ & $\begin{array}{l}355 \\
355 \\
355 \\
355 \\
355 \\
355 \\
355 \\
355 \\
355 \\
355 \\
355 \\
355 \\
355 \\
355 \\
355 \\
353 \\
355 \\
355\end{array}$ & $\begin{array}{r}4157 \\
1894 \\
6291 \\
10474 \\
10249 \\
10249 \\
5911 \\
1571 \\
1571 \\
1571 \\
1571 \\
1571 \\
1571 \\
1571 \\
2744 \\
2744 \\
2744 \\
7390\end{array}$ & $\begin{array}{l}1157 \\
1847 \\
6047 \\
9870 \\
9468 \\
9283 \\
5249 \\
1368 \\
1341 \\
1315 \\
1289 \\
1263 \\
1239 \\
1214 \\
2080 \\
2039 \\
1999 \\
5279\end{array}$ \\
\hline TOTAL & 9008 & 3650 & 22516 & $\overline{30490}$ & 3780 & 6390 & 73834 & 86346 \\
\hline
\end{tabular}

- DeCOMmISsioning COST

INITIAL PAYMENT = $130 \% / \mathrm{KgU}$ (INCLUDEg $5 / \mathrm{KgIJ}$ IMPACT AID)

FINAL PAYMENT - 115 Kou (INCLUdEs *10/KQU IMPACT AID)

TABLE A9-35

ESTIMATED SPENDING SCHEDULE FOR GTORAGE OF 471 GILOS ( 800 MTU)

AT GOVERNMENT SITE WITH EXISTING FACILITIES

$(\$ 000,1989)$

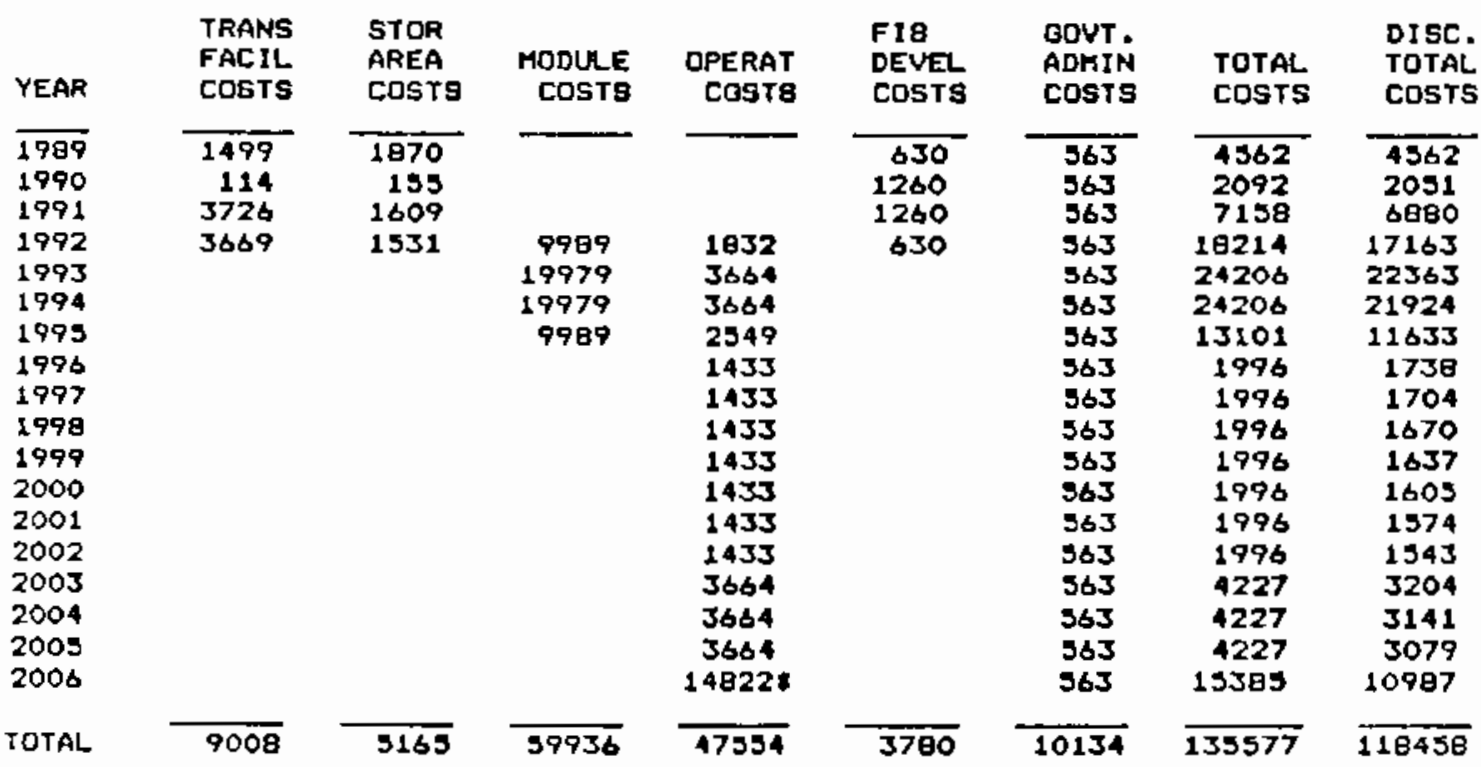

* DECOMMISSIONING COST

INITIAL PAYMENT * $97 * / \mathrm{KgU}$ (INCLUDES $5 / \mathrm{KgU}$ IMPACT AID)

FINAL PAYMENT - 71 KgU (INCLUDES * 10/KgU IMPACT AID) 
TABLE $19-36$

ESTIMATED SFENDING SCHEDLLE FOR GTORAGE OF 984 9ILO8 ( 1500 MTU) AT QOVERNMENT SITE WITH EXIGTING FACILITIES

(\%000, 1989)

\begin{tabular}{|c|c|c|c|c|c|c|c|c|}
\hline YEAR & $\begin{array}{l}\text { TRANS } \\
\text { FACIL } \\
\text { COSTS }\end{array}$ & $\begin{array}{l}\text { STOR } \\
\text { AREA } \\
\text { COSTS }\end{array}$ & $\begin{array}{l}\text { MODULE } \\
\text { COSTS }\end{array}$ & $\begin{array}{r}\text { OPERAT } \\
\text { COSTE }\end{array}$ & $\begin{array}{l}\text { FIg } \\
\text { DEVEL } \\
\text { COgTg }\end{array}$ & $\begin{array}{l}\text { GOVT. } \\
\text { ADMIN } \\
\text { COSTE }\end{array}$ & $\begin{array}{l}\text { TOTAL } \\
\text { COSTS }\end{array}$ & $\begin{array}{l}\text { DISC, } \\
\text { TOTAL } \\
\text { COSTS }\end{array}$ \\
\hline $\begin{array}{l}1999 \\
1990 \\
1991 \\
1992 \\
1993 \\
1994 \\
1995 \\
1996 \\
1997 \\
1998 \\
1999 \\
2000 \\
2001 \\
2002 \\
2003 \\
2004 \\
2005 \\
2006\end{array}$ & $\begin{array}{r}1499 \\
114 \\
3726 \\
3669\end{array}$ & $\begin{array}{r}2136 \\
135 \\
2495 \\
2419\end{array}$ & $\begin{array}{l}19745 \\
37490 \\
37490 \\
18745\end{array}$ & $\begin{array}{c}2531 \\
5062 \\
5062 \\
3390 \\
1734 \\
1734 \\
1734 \\
1734 \\
1734 \\
1734 \\
1734 \\
5062 \\
5062 \\
5062 \\
25736\end{array}$ & $\begin{array}{r}630 \\
1260 \\
1260 \\
630\end{array}$ & $\begin{array}{l}789 \\
789 \\
789 \\
789 \\
789 \\
789 \\
789 \\
789 \\
789 \\
789 \\
789 \\
799 \\
789 \\
789 \\
789 \\
78.9 \\
789 \\
789\end{array}$ & $\begin{array}{r}5054 \\
2319 \\
6270 \\
29782 \\
43341 \\
43341 \\
22932 \\
2523 \\
2523 \\
2523 \\
2523 \\
2523 \\
2523 \\
2523 \\
5851 \\
5851 \\
5851 \\
26525\end{array}$ & $\begin{array}{r}5054 \\
2273 \\
7949 \\
27122 \\
40040 \\
39255 \\
20363 \\
2196 \\
2153 \\
2111 \\
2070 \\
2029 \\
1909 \\
1950 \\
4434 \\
4347 \\
4262 \\
18943\end{array}$ \\
\hline TOTAL & 9000 & 7204 & $\overline{112470}$ & 69113 & 3790 & 14202 & $\overline{215777}$ & 199540 \\
\hline
\end{tabular}

* DECOMMISSIONING COST

INITIAL PAYMENT = 89 /KOU (INCLUDES * S/KQU IMPACT AID)

FINAL PAYMENT = 55 KOU (INCLUDES $9 / \mathrm{KgU}$ IMPACT AID)

TABLE A9-37

ESTIMATED SFENDING SCHEDULE FOR 8TCRAGE OF 1120 SILOS ( 1900 MTU) AT GOVERNMENT GITE WITH EXISTINO FACILITIES

(1000, 1989)

\begin{tabular}{|c|c|c|c|c|c|c|c|c|}
\hline YEAR & $\begin{array}{l}\text { TRANS } \\
\text { FACIL } \\
\text { COSTS }\end{array}$ & $\begin{array}{l}\text { 9TOR } \\
\text { AREA } \\
\text { COSTS }\end{array}$ & $\begin{array}{l}\text { MODULE } \\
\text { COSTS }\end{array}$ & $\begin{array}{l}\text { OPERAT } \\
\text { COSTS }\end{array}$ & $\begin{array}{l}\text { F1s } \\
\text { DEVEL } \\
\text { COSTg }\end{array}$ & $\begin{array}{l}\text { GOVT, } \\
\text { ADMIN } \\
\text { COSTE }\end{array}$ & $\begin{array}{l}\text { TOTAL } \\
\text { COSTS }\end{array}$ & $\begin{array}{l}\text { DISC, } \\
\text { TOTAL } \\
\text { COSTS }\end{array}$ \\
\hline $\begin{array}{l}1999 \\
1990 \\
1991 \\
1992 \\
1993 \\
1994 \\
1995 \\
1996 \\
1997 \\
1998 \\
1999 \\
2000 \\
2001 \\
2002 \\
2003 \\
2004 \\
2005 \\
2006\end{array}$ & $\begin{array}{r}1499 \\
114 \\
3726 \\
3669\end{array}$ & $\begin{array}{r}2296 \\
135 \\
2994 \\
2916\end{array}$ & $\begin{array}{l}23748 \\
47497 \\
47497 \\
23749\end{array}$ & $\begin{array}{c}2931 \\
3962 \\
5862 \\
3805 \\
1908 \\
1908 \\
1908 \\
1908 \\
1908 \\
1908 \\
1908 \\
5862 \\
5962 \\
5862 \\
319708\end{array}$ & $\begin{array}{r}630 \\
1260 \\
1260 \\
630\end{array}$ & $\begin{array}{l}900 \\
900 \\
900 \\
900 \\
900 \\
900 \\
900 \\
900 \\
900 \\
900 \\
900 \\
900 \\
900 \\
900 \\
900 \\
900 \\
900 \\
900\end{array}$ & $\begin{array}{r}5315 \\
2429 \\
9890 \\
34794 \\
34259 \\
34259 \\
28533 \\
2800 \\
2809 \\
2808 \\
2808 \\
2808 \\
2808 \\
2808 \\
6762 \\
6762 \\
6762 \\
32870\end{array}$ & $\begin{array}{r}5313 \\
2381 \\
9535 \\
32787 \\
50127 \\
49144 \\
25336 \\
2445 \\
2397 \\
2350 \\
2304 \\
2259 \\
2214 \\
2171 \\
5125 \\
5024 \\
4926 \\
23475\end{array}$ \\
\hline TOTAL & 9008 & 8331 & 142490 & 81452 & 3780 & 16200 & 261281 & 228314 \\
\hline
\end{tabular}

- DECOMMISSIONING COST

INITIAL PAYMENT = $95 / \mathrm{KgL}$ (INCLUDES $4 / \mathrm{KOU}$ IMPACT AID)

FINAL PAYMENT $=\$ 2$ KKUU (INCLUDES $9 / \mathrm{KgU}$ IMPACT AID) 
10.0 SENSITIVITY OF COSTS TO CHANGES IN CONDITIONS

. The sensitivity of costs for FIS to changing conditions of cost, schedule, mix of spent fuel types, and discount rate, and to whether or not the facility was subject to NRC licensing, was determined for the drywell at storage capacity levels of 100 MTU and 1900 MTU. The following sections describe the conditions considered and the impact of each on the total discounted cost of FIS system construction and operation and the total unit cost.

\subsection{IMPACT OF COST CHANGES}

The impact of design improvements which result in a reduction in capital cost of a new transfer facility to \$15-million and \$10-million, and a reduction in the capital cost of modifying an existing transfer facility to \$8-million on FIS costs is shown in Table A10-1.

TABLE A10-1

IMPACT OF REDUCTIONS IN CAPITAL COSTS OF TRANSFER FACILITIES

ON FIS SYSTEM COSTS

Capital Cost

(s-Millions)

New Facility Cases

$\$ 22.6$ (Base Case)

15

10

Change per \$-million

Existing Facility Cases

9.0 (Base Case)

8.0

Change per \$-million

\begin{tabular}{cc} 
Total & 100 MTU \\
Discounted & Unit \\
Cost $(\$ 000)$ & Cost $(\$ / \mathrm{kgU})$ \\
\hline
\end{tabular}

$\$ 68,659$

59,889

54,087

1,157

$$
\$ 48,775
$$

47,605

1,170
$\$ 730$

641

582

12

$\$ 525$

513

12

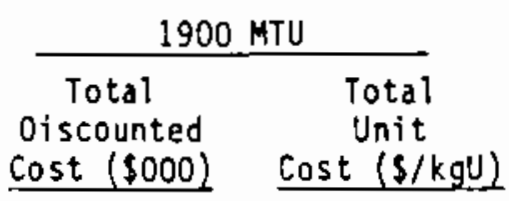

$\$ 242,158$

$\$ 146$

233,390

140

227,601

1,155

137

1

$\$ 131$

$\$ 218,545$

130

217,392

1,153

The estimated spending schedules, discounted annual costs, and the calculation of the Initial and Final Payments for FIS of spent fuel for each of the cases considered in Table A10-l are set forth in Tables A10-2 through A10-7. 
TABLE A10-2

COST SENSITIVITY CASE - - \$15-MILLION TRANSFER FACILITY

ESTIMATED SPENDING SCHEDLLE FOR STORAGE OF 236 DRYWELLS ( $100 \mathrm{MTU})$ AT GOVERNMENT SITE WITHOUT EXISTING FACILITIES

$(\$ 000,1989)$

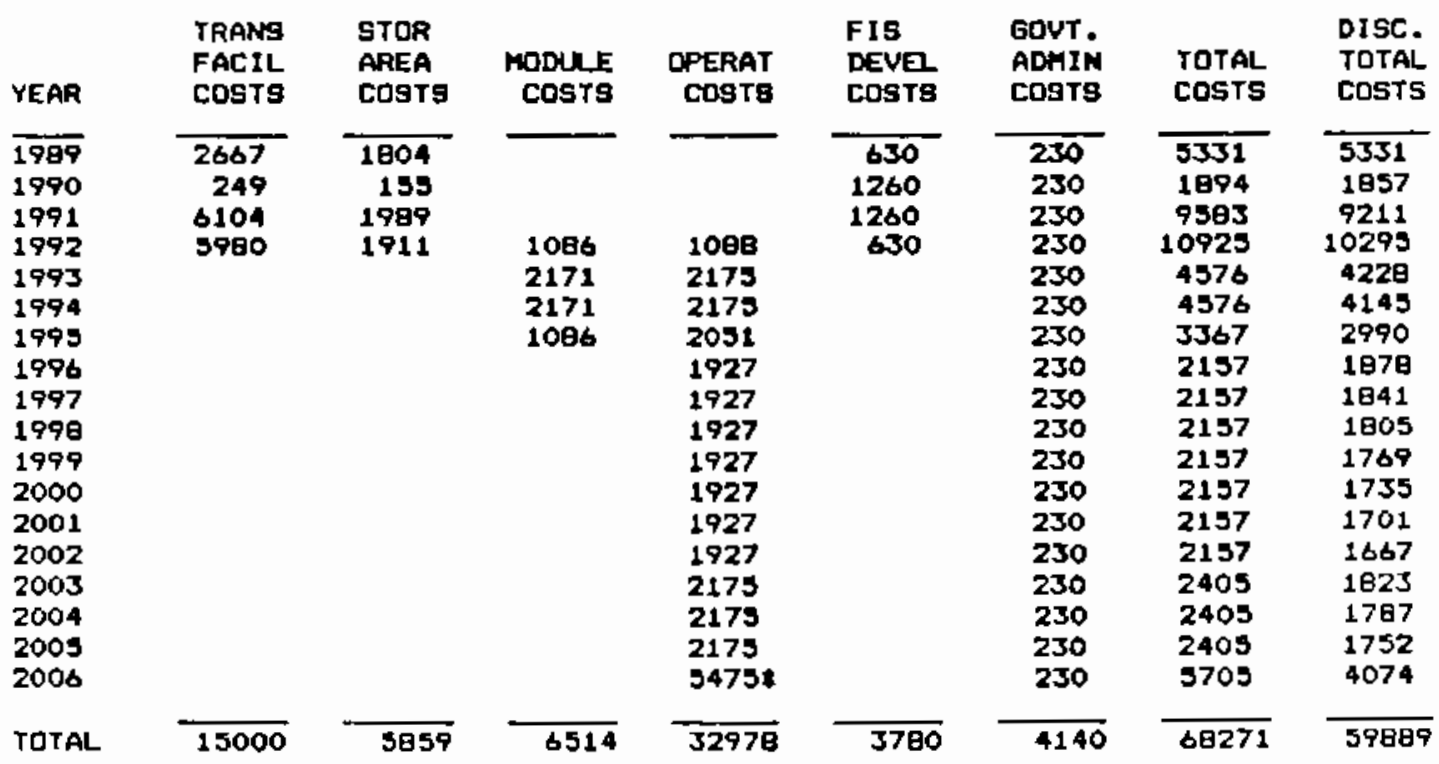

* - decommissianing cost

INITIAL PAYMENT $=310 * / \mathrm{KgU}$ (INCLUDES *5/KgU IMPACT AID)

FINAL PAyment - 331 KoU (INCLUDES * 10/KgU IMPACT AID)

TABLE A10-3

COST SENSITIVITY CASE - \$10-MILLION TRANSFER FACILITY

ESTIMATED SPENDING SCHEDLLE FOR STORAGE OF 236 DRYWELLS ( $100 \mathrm{MTU})$ AT GOVERNMENT SITE WITHOUT EXISTING FACILITIES

$(\$ 000,1989)$

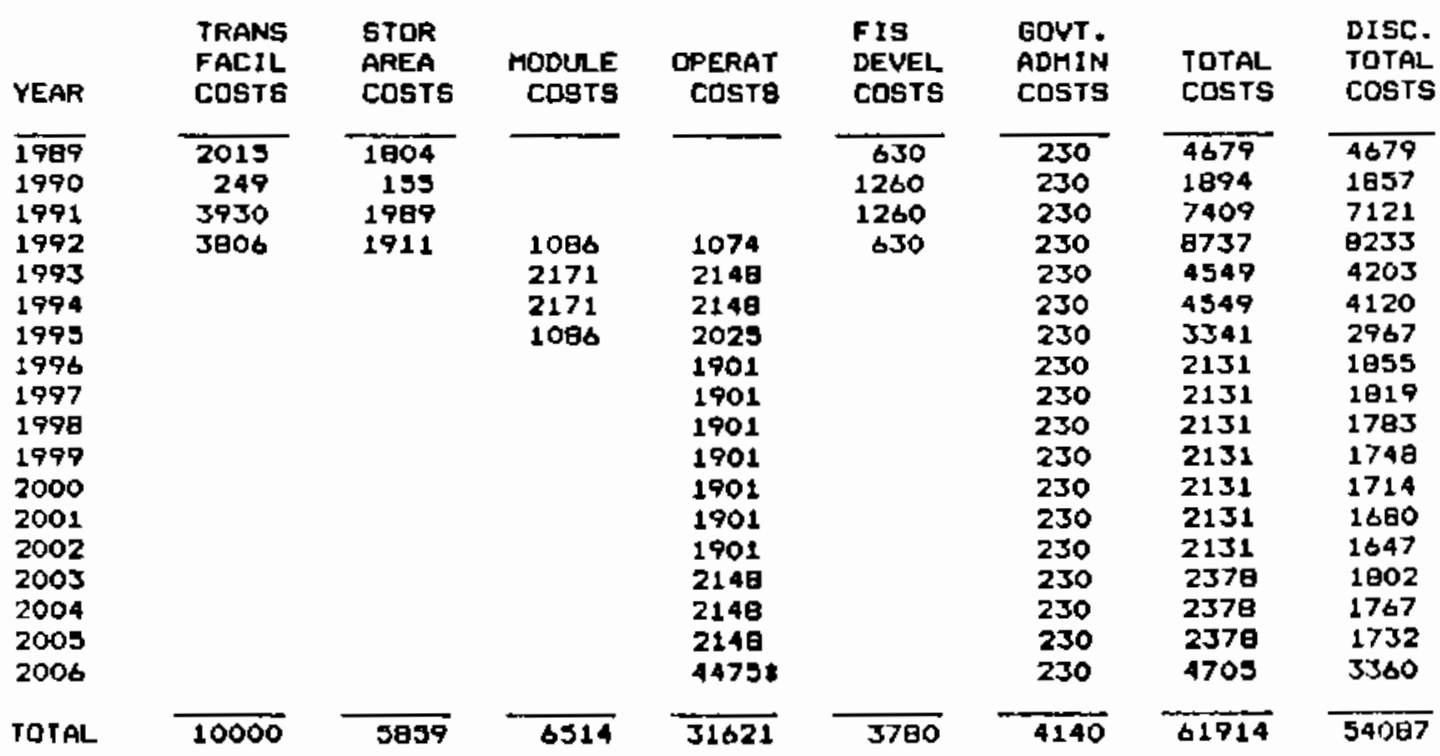

* DECOMHISSIONING COST

IN1TIAL PAYMENT = $262 * \mathrm{KgU}$ (INCLUDES *5/KgU IMPACT AID)

FINAL PAYMENT = 320 KOU (INCLUDES $10 / \mathrm{KgU}$ IMPACT AID) 
TABLE A10-4

COST SENSITIVITY CASE - \$15-MILLION TRANSFER FACILITY

ESTIMATED SPENDING SCHEDULE FOR STORAGE OF 447A DRYWELLS ( $1900 \mathrm{MTU}$ )

AT GOVERNHENT SITE WITHOUT EXISTING FACILITIES

$(\$ 000,1989)$

\begin{tabular}{|c|c|c|c|c|c|c|c|c|}
\hline YEAR & $\begin{array}{l}\text { TRANS } \\
\text { FACIL } \\
\text { COSTS }\end{array}$ & $\begin{array}{l}\text { STOR } \\
\text { AREA } \\
\text { COSTE }\end{array}$ & $\begin{array}{r}\text { MOOLLE } \\
\text { COSTS }\end{array}$ & $\begin{array}{r}\text { OPERAT } \\
\text { COSTS }\end{array}$ & $\begin{array}{l}\text { FIS } \\
\text { DEVEL. } \\
\text { COSTS }\end{array}$ & $\begin{array}{l}\text { BOVT. } \\
\text { ADMIN } \\
\text { COSTS }\end{array}$ & $\begin{array}{l}\text { TOTAL } \\
\text { COSTS }\end{array}$ & $\begin{array}{l}\text { DISC. } \\
\text { TOTAL } \\
\text { COSTS }\end{array}$ \\
\hline $\begin{array}{l}1989 \\
1990 \\
1991 \\
1992 \\
1993 \\
1994 \\
1995 \\
1996 \\
1997 \\
1998 \\
1999 \\
2000 \\
2001 \\
2002 \\
2003 \\
2004 \\
2005 \\
2006\end{array}$ & $\begin{array}{r}2667 \\
249 \\
6104 \\
5980\end{array}$ & $\begin{array}{r}2260 \\
155 \\
3509 \\
3432\end{array}$ & $\begin{array}{l}20600 \\
41201 \\
41201 \\
20600\end{array}$ & $\begin{array}{c}3830 \\
7660 \\
7660 \\
5462 \\
3264 \\
3264 \\
3264 \\
3264 \\
3264 \\
3264 \\
3264 \\
7660 \\
7660 \\
7660 \\
29592\end{array}$ & $\begin{array}{r}630 \\
1260 \\
1260 \\
630\end{array}$ & $\begin{array}{l}900 \\
900 \\
900 \\
900 \\
900 \\
900 \\
900 \\
900 \\
900 \\
900 \\
900 \\
900 \\
900 \\
900 \\
900 \\
900 \\
900 \\
900\end{array}$ & $\begin{array}{r}6457 \\
2564 \\
11773 \\
35372 \\
49761 \\
49761 \\
26962 \\
4164 \\
4164 \\
4164 \\
4164 \\
4164 \\
4164 \\
4164 \\
9560 \\
9560 \\
9560 \\
50492\end{array}$ & $\begin{array}{r}6457 \\
2514 \\
11316 \\
33332 \\
45971 \\
45070 \\
23941 \\
3625 \\
3554 \\
3484 \\
3416 \\
3349 \\
3263 \\
3219 \\
6487 \\
6360 \\
6236 \\
21776\end{array}$ \\
\hline
\end{tabular}

* - decomisisioning cost

INITIAL PAYMENT $=79 * / \mathrm{KgU}$ (INCLUDES * 4/KgU IMPACT AID)

FINAL PAYMENT = 61 KgU (INCLUDES $9 / \mathrm{KgU}$ IMPACT AID)

TABLE A10-5

COST SENSITIVITY CASE - \$10-HILLION TRANSFER FACILITY

ESTIMATED SPENDING SCHEDULE FOR STORAGE OF 4478 DRYWELLS ( 1900 MTU) AT GOVERNHENT SITE WITHOUT EXISTING FACILITIES (\$000, 1989)

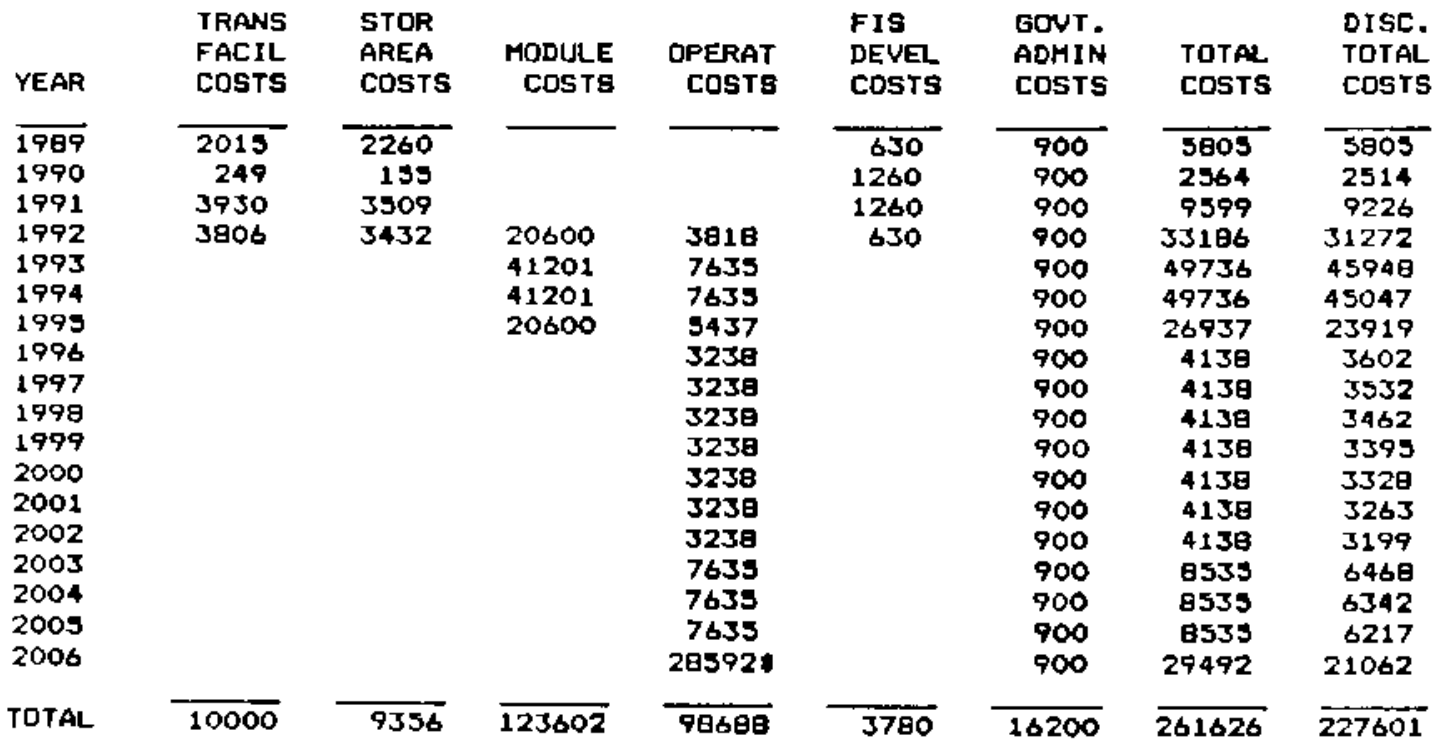

- DEComissioning cost

INITIAL PAYMENT - 77 \$/KgU (INCLUDES 4/KgU IMPACT AID)

FINAL PAYMENT - 60 KKU (INCLUDEs * $9 / \mathrm{KgU}$ IHPACT A1D) 
TABLE A10-6

COST SENSITIVITY CASE - \$8-MILLION TRANSFER FACILITY

ESTIMATED SPENDING SCHEDULE FOR GTORAGE OF 236 DRYWELLS ( 100 MTU) AT GOVERNMENT SITE WITH EXISTINO FACILITIES

(\$000, 1989)

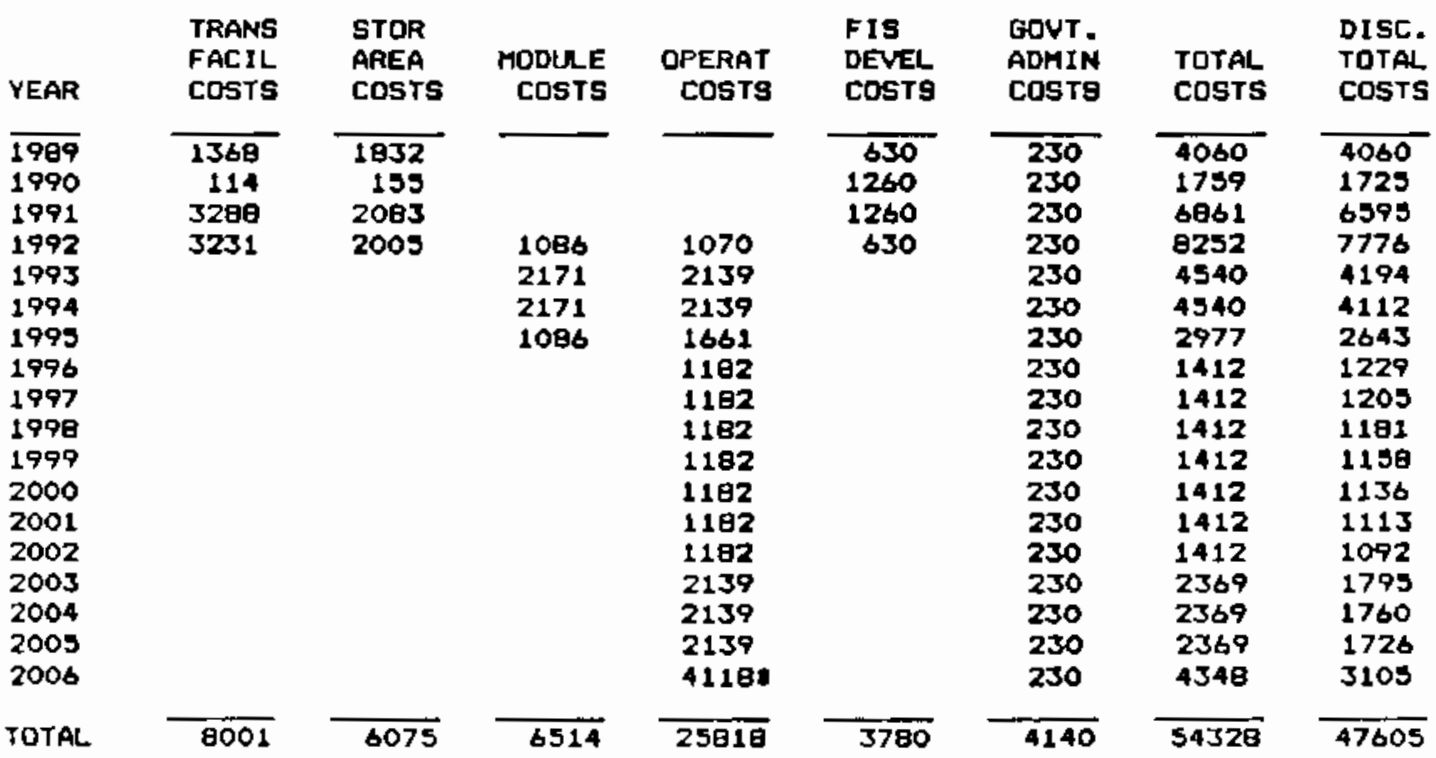

* - decomisisioning cost

INITIAL PAYMENT = $244 * / K G U$ (INCLUDES * $5 / K g U$ IMPACT AID)

FINAL PAYMENT $=269$ KgU (INCLUDES *10/KgL IMPACT AID)

TABLE AL O-7

COST SENSITIVITY CASE -- SB-MILLION TRANSFER FACILITY

ESTIMATED SPENDING SCHEDULE FOR STORAGE OF 4479 DRYWELLS ( 1900 MTU)

AT GOVERNMENT SITE WITH EXIGTINB FACILITIES

$(\$ 000,1909)$

\begin{tabular}{|c|c|c|c|c|c|c|c|c|}
\hline YEAR & $\begin{array}{l}\text { TRANS } \\
\text { FACIL } \\
\text { COSTS }\end{array}$ & $\begin{array}{l}\text { STOR } \\
\text { AREA } \\
\text { COSTS }\end{array}$ & $\begin{array}{l}\text { MODULE } \\
\text { COSTS }\end{array}$ & $\begin{array}{r}\text { DPERAT } \\
\text { COSTR }\end{array}$ & $\begin{array}{l}\text { F18 } \\
\text { DEVEL } \\
\text { Cost8 }\end{array}$ & $\begin{array}{l}\text { GOVT. } \\
\text { ADHIN } \\
\text { COSTS }\end{array}$ & $\begin{array}{l}\text { TOTAL } \\
\text { COSTS }\end{array}$ & $\begin{array}{l}\text { DISC. } \\
\text { TOTAL } \\
\text { COSTS }\end{array}$ \\
\hline $\begin{array}{l}1999 \\
1990 \\
1991\end{array}$ & $\begin{array}{r}1366 \\
114 \\
3286\end{array}$ & $\begin{array}{r}2280 \\
155 \\
3603\end{array}$ & & & $\begin{array}{l}630 \\
1260 \\
1260\end{array}$ & $\begin{array}{l}900 \\
900 \\
900\end{array}$ & $\begin{array}{l}5186 \\
2429 \\
9051\end{array}$ & $\begin{array}{l}5186 \\
2381 \\
8700\end{array}$ \\
\hline $\begin{array}{l}1992 \\
1993 \\
1994\end{array}$ & 3231 & 3525 & $\begin{array}{l}20800 \\
41201 \\
41201\end{array}$ & $\begin{array}{l}3913 \\
7626 \\
7626\end{array}$ & 630 & $\begin{array}{l}900 \\
900 \\
900\end{array}$ & $\begin{array}{l}32699 \\
49727 \\
49727\end{array}$ & $\begin{array}{l}30813 \\
45940 \\
45039\end{array}$ \\
\hline 1995 & & & 20600 & 4772 & & 900 & 26272 & 23329 \\
\hline $\begin{array}{l}1996 \\
1997\end{array}$ & & & & $\begin{array}{l}1917 \\
1917\end{array}$ & & $\begin{array}{l}900 \\
900\end{array}$ & $\begin{array}{l}2817 \\
2817\end{array}$ & $\begin{array}{l}2452 \\
2404\end{array}$ \\
\hline 1998 & & & & 1917 & & 900 & 2817 & 2357 \\
\hline 1999 & & & & 1917 & & 900 & 2817 & 2311 \\
\hline 2000 & & & & 1917 & & 900 & 2817 & 2266 \\
\hline 2001 & & & & 1917 & & 900 & 2817 & 2221 \\
\hline 2002 & & & & 1917 & & 900 & 2817 & 2178 \\
\hline 2003 & & & & 7026 & & 900 & 8526 & 6462 \\
\hline 2004 & & & & 7626 & & 900 & 8526 & 6335 \\
\hline 2005 & & & & 7626 & & 900. & 8526 & 6211 \\
\hline 2006 & & & & $28235 *$ & & 900 & 29135 & 20007 \\
\hline TOTAL & 9001 & 9571 & $\overline{123602}$ & 89369 & 3780 & 16200 & 249523 & 217392 \\
\hline
\end{tabular}

* - DECOMMISSIONING COST

INITIAL PAYMENT $=76 \% / K Q U$ (INCLUDES $\$ 4 / \mathrm{K}$ U IMPACT AID)

FINAL PAYMENT $=54$ KgU (INCLUDES $1 / \mathrm{KgU}$ IMPACT AID) 
The impact of reductions in the cost of individual modules (drywells) and canisters on FIS costs is shown in Table Al0-8.

TABLE A10-8

IMPACT OF REDUCTIONS IN COST OF DRYWELLS AND CANISTERS

DN FIS SYSTEM COSTS

\begin{tabular}{|c|c|c|c|c|}
\hline \multirow[b]{2}{*}{ Item Cost $(\$)$} & \multicolumn{2}{|c|}{$100 \mathrm{MTU}$} & \multicolumn{2}{|c|}{$1900 \mathrm{MTU}$} \\
\hline & $\begin{array}{c}\text { Total } \\
\text { Discounted } \\
\text { Cost }(\$ 000) \\
\end{array}$ & $\begin{array}{c}\text { Total } \\
\text { Unit } \\
\text { Cost }(\$ / \mathrm{kgU}) \\
\end{array}$ & $\begin{array}{c}\text { Total } \\
\text { Discounted } \\
\text { Cost }(\$ 000) \\
\end{array}$ & $\begin{array}{c}\text { Total } \\
\text { Unit } \\
\text { Cost }(\$ / \mathrm{kgU}) \\
\end{array}$ \\
\hline \multicolumn{5}{|l|}{ Drywells } \\
\hline$\$ 22,617$ & $\$ 68,659$ & $\$ 730$ & $\$ 242,158$ & $\$ 146$ \\
\hline 15,000 & 66,652 & 710 & 204,116 & 124 \\
\hline 10,000 & 65,344 & 696 & 179,137 & 108 \\
\hline Change per $\$$-thousand & 263 & 3 & 4,995 & 3 \\
\hline \multicolumn{5}{|l|}{ Canisters } \\
\hline$\$ 4,985$ & $\$ 68,659$ & $\$ 730$ & $\$ 242,158$ & $\$ 146$ \\
\hline 3,500 & 68,288 & 726 & 235,123 & 142 \\
\hline 2,000 & 67,914 & 723 & 228,018 & 138 \\
\hline Change per $\$$-thousand & 250 & 2 & 4,737 & 3 \\
\hline
\end{tabular}

The estimated spending schedules, discounted annual costs, and the calculation of the Initial and Final Payments for FIS of spent fuel for each of the cases considered in Table A10-8 are set forth in Tables A10-9 through A10-16. 
TABLE AIO-9

COST SENSITIVITY CASE - $\$ 15,000$ ORYWELL

ESTIMATED SPENDING SCHEDULE FOR STORAGE OF 236 DRYWELL9 ( 100 MTU)

AT GOVERNHENT SITE WITHOUT EXISTING FACILITIES

(*000, 1989)

\begin{tabular}{|c|c|c|c|c|c|c|c|c|}
\hline YEAR & $\begin{array}{l}\text { TRANS } \\
\text { FACIL } \\
\text { COSTS }\end{array}$ & $\begin{array}{l}\text { STOR } \\
\text { AREA } \\
\text { COSTS }\end{array}$ & $\begin{array}{r}\text { MODULE } \\
\text { COST9 }\end{array}$ & $\begin{array}{r}\text { OPERAT } \\
\text { COSTR }\end{array}$ & $\begin{array}{l}\text { FIS } \\
\text { DEVEL } \\
\text { COSTR }\end{array}$ & $\begin{array}{l}\text { GONT. } \\
\text { ADHIN } \\
\text { COST }\end{array}$ & $\begin{array}{l}\text { TOTAL } \\
\text { COSTS }\end{array}$ & $\begin{array}{l}\text { DISC. } \\
\text { TOTAL } \\
\text { COSTS }\end{array}$ \\
\hline $\begin{array}{l}1989 \\
1990 \\
1991 \\
1992 \\
1993 \\
1994 \\
1995 \\
1996 \\
1997 \\
1998 \\
1999 \\
2000 \\
2001 \\
2002 \\
2003 \\
2004 \\
2005 \\
2006\end{array}$ & $\begin{array}{r}3654 \\
249 \\
9395 \\
9270\end{array}$ & $\begin{array}{r}1804 \\
155 \\
1989 \\
1911\end{array}$ & $\begin{array}{r}786 \\
1572 \\
1572 \\
786\end{array}$ & $\begin{array}{l}1103 \\
2205 \\
2205 \\
2081 \\
1957 \\
1957 \\
1957 \\
1957 \\
1957 \\
1957 \\
1957 \\
2205 \\
2205 \\
2205 \\
66298\end{array}$ & $\begin{array}{r}630 \\
1260 \\
1260 \\
630\end{array}$ & $\begin{array}{l}230 \\
230 \\
230 \\
230 \\
230 \\
230 \\
230 \\
230 \\
230 \\
230 \\
230 \\
230 \\
230 \\
230 \\
230 \\
230 \\
230 \\
230\end{array}$ & $\begin{array}{r}6318 \\
1894 \\
12974 \\
13930 \\
4007 \\
4007 \\
3097 \\
2187 \\
2187 \\
2187 \\
2187 \\
2197 \\
2187 \\
2187 \\
2435 \\
2435 \\
2435 \\
6959\end{array}$ & $\begin{array}{r}6319 \\
1857 \\
12374 \\
13127 \\
3702 \\
3629 \\
2750 \\
1904 \\
1867 \\
1830 \\
1794 \\
1759 \\
1724 \\
1691 \\
1845 \\
1809 \\
1774 \\
4890\end{array}$ \\
\hline TOTAL & 22568 & $5 \overline{589}$ & 4716 & 34537 & $\overline{3780}$ & $\overline{4140}$ & 75600 & 66652 \\
\hline
\end{tabular}

\section{* - decomissioning cost}

INITIAL PAYMENT = 366 \$ KOU (INCLUDES *5/KoU IMFACT AID)

FINAL PAYMENT = 344 *KOU (INCLUDEG *10/KgL IMPACT AID)

TABLE A10-10

COST SENSITIVITY CASE - $\$ 10,000$ DRYWELL

ESTIMATED SPENDING SCHEDULE FDR STORAGE OF 236 DRYWELLS ( $100 \mathrm{MTU}$ ) AT GOVERNMENT SITE WITHOUT EXISTING FACILITIES

\begin{tabular}{|c|c|c|c|c|c|c|c|c|}
\hline YEAR & $\begin{array}{l}\text { TRANS } \\
\text { FACIL } \\
\text { COSTS }\end{array}$ & $\begin{array}{l}\text { STDR } \\
\text { AREA } \\
\text { COSTS }\end{array}$ & $\begin{array}{r}\text { MODULE } \\
\text { COSTS }\end{array}$ & $\begin{array}{r}\text { DPERAT } \\
\text { COSTS }\end{array}$ & $\begin{array}{l}\text { FIS } \\
\text { DEVEL } \\
\text { COSTS }\end{array}$ & $\begin{array}{l}\text { GOVT. } \\
\text { ADMIN } \\
\text { COSTS }\end{array}$ & $\begin{array}{l}\text { TOTAL } \\
\text { COSTS }\end{array}$ & $\begin{array}{l}\text { DISC, } \\
\text { TOTAL } \\
\text { COSTS }\end{array}$ \\
\hline $\begin{array}{l}1989 \\
1990\end{array}$ & $\begin{array}{r}3654 \\
249\end{array}$ & $\begin{array}{r}1804 \\
155\end{array}$ & & & $\begin{array}{r}630 \\
1260\end{array}$ & $\begin{array}{l}230 \\
230\end{array}$ & $\begin{array}{r}6318 \\
1894\end{array}$ & $\begin{array}{r}6318 \\
1857\end{array}$ \\
\hline 1991 & 9375 & 1809 & & & $\begin{array}{r}1260 \\
630\end{array}$ & $\begin{array}{l}230 \\
230\end{array}$ & $\begin{array}{l}12874 \\
13730\end{array}$ & $\begin{array}{l}12374 \\
12938\end{array}$ \\
\hline $\begin{array}{l}1992 \\
1993 \\
1994\end{array}$ & 9270 & & $\begin{array}{r}589 \\
1179 \\
1179\end{array}$ & $\begin{array}{l}1100 \\
2199 \\
2199\end{array}$ & 630 & $\begin{array}{l}230 \\
230 \\
230\end{array}$ & $\begin{array}{r}13730 \\
3600 \\
3609\end{array}$ & $\begin{array}{r}12938 \\
3333 \\
3268\end{array}$ \\
\hline 1975 & & & 589 & 2076 & & 230 & 2895 & 2571 \\
\hline $\begin{array}{l}1996 \\
1797\end{array}$ & & & & $\begin{array}{l}1952 \\
1952\end{array}$ & . & $\begin{array}{l}230 \\
230\end{array}$ & $\begin{array}{l}2182 \\
2182\end{array}$ & $\begin{array}{l}1900 \\
1862\end{array}$ \\
\hline 1998 & & & & 1952 & & 230 & 2182 & 1826 \\
\hline 1999 & & & & 1952 & & 230 & $21 \mathrm{B2}$ & 1790 \\
\hline 2000 & & & & 1952 & & 230 & 2162 & 1755 \\
\hline 2001 & & & & 1952 & & 230 & 2182 & 1720 \\
\hline 2002 & & & & 1952 & & 230 & 2182 & 1687 \\
\hline 2003 & & & & 2199 & & 230 & 2429 & 1841 \\
\hline 2004 & & & & 2199 & & 230 & 2429 & 1005 \\
\hline 2003 & & & & 2199 & & 230 & 2429 & 1769 \\
\hline 2006 & & & & $6393:$ & & 230 & 6623 & 4730 \\
\hline TOTAL & 22568 & 5859 & 3536 & 34228 & 3780 & 4140 & 74111 & 65344 \\
\hline
\end{tabular}

* - DeCOMmissioning COST

INITIAL PAYMENT = 355 / KgU (INCLUDEg $5 / \mathrm{KgU}$ IMPACT AID)

FINAL PAYMENT = 341 kgU (INCLUDES $10 / \mathrm{KgL}$ IMFACT AID) 
TABLE A10-11

COST SENSITIVITY CASE $\cdots \$ 15,000$ DRYHELL

ESTIMATED SFENDING SCREDULE FOR STORAGE OF 4478 DRYWELLS ( $1900 \mathrm{MTU})$

AT GOVEFNMENT SITE WITHOUT EXISTING FACILITIES

$(\$ 000,1989)$

\begin{tabular}{|c|c|c|c|c|c|c|c|c|}
\hline YEAR & $\begin{array}{l}\text { TRANS } \\
\text { FACIL. } \\
\text { COSTS }\end{array}$ & $\begin{array}{l}\text { STOR } \\
\text { AREA } \\
\text { COSTS }\end{array}$ & $\begin{array}{r}\text { MODULE } \\
\text { COST9 }\end{array}$ & $\begin{array}{r}\text { OPERAT } \\
\text { COSTS }\end{array}$ & $\begin{array}{l}\text { F IS } \\
\text { DEVEL } \\
\text { COSTS }\end{array}$ & $\begin{array}{l}\text { GOVT } \\
\text { ADMIN } \\
\text { COSTS }\end{array}$ & $\begin{array}{l}\text { TOTAL } \\
\text { COSTS }\end{array}$ & $\begin{array}{l}\text { DISC. } \\
\text { TOTAL } \\
\text { COSTS }\end{array}$ \\
\hline 1989 & 3654 & 2260 & & & 630 & 900 & 7444 & 7444 \\
\hline 1990 & 247 & 135 & & & 1260 & 900 & 2564 & 2514 \\
\hline 1991 & 9.395 & 3509 & & & 1260 & 900 & 15064 & 14479 \\
\hline $\begin{array}{l}1992 \\
1993\end{array}$ & 9270 & 3432 & $\begin{array}{l}14915 \\
290.31\end{array}$ & $\begin{array}{l}3762 \\
7523\end{array}$ & 630 & $\begin{array}{l}900 \\
900\end{array}$ & $\begin{array}{l}32909 \\
38254\end{array}$ & $\begin{array}{l}31011 \\
35341\end{array}$ \\
\hline 1994 & & & 29831 & 7523 & & 900 & 38254 & 34648 \\
\hline 1995 & & & 14915 & 5325 & & 900 & 21140 & 10772 \\
\hline 1996 & & & & 3127 & & 900 & 4027 & 3506 \\
\hline 1997 & & & & 3127 & & 900 & 4027 & 3437 \\
\hline 1998 & & & & 3127 & & 900 & 4027 & 3370 \\
\hline 1999 & & & & 3127 & & 900 & 4027 & 3304 \\
\hline 2000 & & & & 3127 & & 900 & 4027 & 3239 \\
\hline 2001 & & & & 3127 & & 900 & 4027 & 3175 \\
\hline 20012 & & & & 3127 & & 900 & 4027 & 3113 \\
\hline 2003 & & & & 7523 & & 900 & 8423 & 6.384 \\
\hline 2004 & & & & 7523 & & 900 & 8423 & 6258 \\
\hline 2009 & & & & 7523 & & 900 & 0423 & 6130 \\
\hline 20106 & & & & $24283 *$ & & 900 & 25183 & 17985 \\
\hline TOTAL & 22568 & 9356 & 89492 & 92874 & 3780 & 16200 & 234270 & 204116 \\
\hline
\end{tabular}

* - decommissioning cost

INITIAL FAYMENT = $67 / K Q U$ (INCLUDES $4 / K g U$ IMFACT AID)

FINAL FAYMENT = 37 KQU (INCLUDES *

TABLE A10-12

COST SENSITIVITY CASE $-\because \$ 10,000$ DRYWELL

¿STIMATED SPENDING SCHEDULE FOR STORAGE OF 4479 DRYWELLS ( 1900 MTU) AT GOVEFNMENT SITE HITHOUT EXISTING FACILITIES

(\$000, 1989)

\begin{tabular}{|c|c|c|c|c|c|c|c|c|}
\hline YEAR & $\begin{array}{l}\text { TRANS } \\
\text { FACIL } \\
\text { COSTS }\end{array}$ & $\begin{array}{l}\text { STOR } \\
\text { AREA } \\
\text { COSTS }\end{array}$ & $\begin{array}{r}\text { MODULE } \\
\text { COSTE }\end{array}$ & $\begin{array}{r}\text { OPERAT } \\
\text { COSTS }\end{array}$ & $\begin{array}{l}\text { FIS } \\
\text { DEVEL } \\
\text { COSTS }\end{array}$ & $\begin{array}{l}\text { GOVT } \\
\text { ADMIN } \\
\text { COSTS }\end{array}$ & $\begin{array}{l}\text { TOTAL } \\
\text { COSTS }\end{array}$ & $\begin{array}{l}\text { DISC. } \\
\text { TOTAL } \\
\text { COSTS }\end{array}$ \\
\hline $\begin{array}{l}1999 \\
1990 \\
1991 \\
1992 \\
1993\end{array}$ & $\begin{array}{r}3654 \\
249 \\
9395 \\
9270\end{array}$ & $\begin{array}{r}2260 \\
155 \\
3509 \\
3432\end{array}$ & $\begin{array}{l}11184 \\
22360\end{array}$ & $\begin{array}{l}3704 \\
7407\end{array}$ & $\begin{array}{r}630 \\
1260 \\
1260 \\
630\end{array}$ & $\begin{array}{l}900 \\
900 \\
900 \\
900 \\
900\end{array}$ & $\begin{array}{r}7444 \\
2564 \\
15064 \\
29120 \\
30675\end{array}$ & $\begin{array}{r}7444 \\
2314 \\
14479 \\
27440 \\
28339\end{array}$ \\
\hline $\begin{array}{l}1994 \\
1995\end{array}$ & & & $\begin{array}{l}22368 \\
11194\end{array}$ & $\begin{array}{l}7407 \\
5209\end{array}$ & & $\begin{array}{l}900 \\
900\end{array}$ & $\begin{array}{l}30675 \\
17293\end{array}$ & $\begin{array}{l}27763 \\
15356\end{array}$ \\
\hline $\begin{array}{l}1996 \\
1997\end{array}$ & & & & $\begin{array}{l}3011 \\
3011\end{array}$ & & $\begin{array}{l}900 \\
900\end{array}$ & $\begin{array}{l}3911 \\
3911\end{array}$ & $\begin{array}{l}3405 \\
3330\end{array}$ \\
\hline $\begin{array}{l}1998 \\
1999\end{array}$ & & & & $\begin{array}{l}3011 \\
3011\end{array}$ & & $\begin{array}{l}900 \\
900\end{array}$ & $\begin{array}{l}3911 \\
3911\end{array}$ & $\begin{array}{l}3273 \\
3208\end{array}$ \\
\hline 2000 & & & & 3011 & & 900 & 3911 & 3145 \\
\hline 2001 & & & & 3011 & & 900 & 3911 & 3064 \\
\hline 2002 & & & & 3011 & & 900 & 3911 & 3023 \\
\hline 2003 & & & & 7407 & & 900 & 8307 & 6296 \\
\hline 2004 & & & & 7407 & & 900 & 8307 & 6172 \\
\hline 2005 & & & & 7407 & & 900 & 0307 & 6051 \\
\hline 2006 & & & & $19806 *$ & & 900 & 20706 & 14707 \\
\hline rOTAL & 22568 & 9356 & 67104 & 86831 & 3700 & 16200 & 205839 & 179137 \\
\hline
\end{tabular}

* DECOMmISSIONING COST

INITIAL PAYMENT = 55 *KgU (INCLUDES *3/KgU IMPACT AID)

FINAL PAYMENT = 53 KGU (INCLUDES $7 / K g U$ IMPACT AID) 
TABLE $A 10-13$

COST SENSITIVITY CASE -- \$3,500 CANISTER

ESTIMATED SPENDINE SCHEDULE FOR STORAGE OF 236 DRYWELLS ( 100 MTU) AT GONERNMENT SITE WITHDUT EXISTING FACILITIES

$(\$ 000,1989)$

\begin{tabular}{|c|c|c|c|c|c|c|c|c|}
\hline YEAR & $\begin{array}{l}\text { TRANS } \\
\text { FACIL } \\
\text { COSTS }\end{array}$ & $\begin{array}{l}\text { STOR } \\
\text { AREA } \\
\text { COSTS }\end{array}$ & $\begin{array}{l}\text { MODULE } \\
\text { COSTE }\end{array}$ & $\begin{array}{r}\text { OPERAT } \\
\text { COSTS }\end{array}$ & $\begin{array}{l}\text { FIg } \\
\text { DEVER } \\
\text { COSTS }\end{array}$ & $\begin{array}{l}\text { GOVT. } \\
\text { ADHIN } \\
\text { COSTE }\end{array}$ & $\begin{array}{l}\text { TOTAL } \\
\text { COSTS }\end{array}$ & $\begin{array}{l}\text { DISC. } \\
\text { TOTAL } \\
\text { COSTS }\end{array}$ \\
\hline $\begin{array}{l}1989 \\
1990 \\
1991 \\
1992 \\
1993 \\
1994 \\
1995 \\
1996 \\
1997 \\
1999 \\
1999 \\
2000 \\
2001 \\
2002 \\
2003 \\
2004 \\
2005 \\
2006\end{array}$ & $\begin{array}{r}3654 \\
249 \\
9395 \\
9270\end{array}$ & $\begin{array}{r}1804 \\
155 \\
1989 \\
1911\end{array}$ & $\begin{array}{l}1027 \\
2055 \\
2055 \\
1027\end{array}$ & $\begin{array}{l}1107 \\
2214 \\
2214 \\
2091 \\
1967 \\
1967 \\
1967 \\
1967 \\
1967 \\
1967 \\
1967 \\
2214 \\
2214 \\
2214 \\
6918\end{array}$ & $\begin{array}{r}630 \\
1260 \\
1260 \\
630\end{array}$ & $\begin{array}{l}230 \\
230 \\
230 \\
230 \\
230 \\
230 \\
230 \\
230 \\
230 \\
230 \\
230 \\
230 \\
230 \\
230 \\
230 \\
230 \\
230 \\
230\end{array}$ & $\begin{array}{r}6319 \\
1894 \\
12974 \\
14175 \\
4499 \\
4499 \\
3349 \\
2197 \\
2197 \\
2197 \\
2197 \\
2197 \\
2197 \\
2197 \\
2444 \\
2444 \\
2444 \\
7149\end{array}$ & $\begin{array}{r}6318 \\
1857 \\
12374 \\
13357 \\
4156 \\
4075 \\
2973 \\
1913 \\
1875 \\
1839 \\
1802 \\
1767 \\
1732 \\
1698 \\
1852 \\
1816 \\
1780 \\
5105\end{array}$ \\
\hline TOTAL & 22568 & $5 \overline{5859}$ & $\overline{6164}$ & 34955 & 3780 & $4 \overline{4140}$ & $\overline{77466}$ & $\overline{68288}$ \\
\hline
\end{tabular}

* Decommissioning cost

INITIAL PAYMENT - $379 * / K O U$ (INCLUDES $\$ 3 / \mathrm{KgU}$ IMPACT AID)

FINAL PAYMENT - 347 IKGU (INCLUDES * 10/KoU IMPACT AID)

TABLE A10-14

COST SENSITIVITY CASE $-\$ 2,000$ CANISTER

ESTIMATED SFENDING SCHEDULE FOR STOFAGE OF ZZD DFYWELLS ( 100 MTU) AT GOVEFINMENT SITE WITHOUT EXISTING FACILITIES

( 1000,1989$)$

\begin{tabular}{|c|c|c|c|c|c|c|c|c|}
\hline YEAR & $\begin{array}{l}\text { TRANS } \\
\text { FACIL } \\
\text { COSTS }\end{array}$ & $\begin{array}{l}\text { STOR } \\
\text { AFEA } \\
\text { COSTS }\end{array}$ & $\begin{array}{r}\text { MODULE } \\
\text { COSTS }\end{array}$ & $\begin{array}{r}\text { OFERAT } \\
\text { COSTS }\end{array}$ & $\begin{array}{l}\text { F IS } \\
\text { DEVEL } \\
\text { COSTS }\end{array}$ & $\begin{array}{l}\text { GOVT. } \\
\text { ADMIN } \\
\text { COSTS }\end{array}$ & $\begin{array}{l}\text { TOTAL } \\
\text { COSTS }\end{array}$ & $\begin{array}{l}\text { DISE. } \\
\text { TOTAL } \\
\text { COSTS }\end{array}$ \\
\hline $\begin{array}{l}1989 \\
1990\end{array}$ & $\begin{array}{r}3654 \\
249\end{array}$ & $\begin{array}{r}1804 \\
153\end{array}$ & & & $\begin{array}{r}630 \\
1260\end{array}$ & $\begin{array}{l}230 \\
230\end{array}$ & $\begin{array}{l}6310 \\
1894\end{array}$ & $\begin{array}{l}6.318 \\
1057\end{array}$ \\
\hline 1991 & 9395 & 1989 & & & 1260 & 230 & 12974 & 12374 \\
\hline $\begin{array}{l}1992 \\
199.3 \\
1994\end{array}$ & 9270 & 1911 & $\begin{array}{r}968 \\
1937 \\
1937\end{array}$ & $\begin{array}{l}1107 \\
2214 \\
2214\end{array}$ & 630 & $\begin{array}{l}230 \\
230 \\
230\end{array}$ & $\begin{array}{r}14116 \\
4301 \\
4391\end{array}$ & $\begin{array}{r}1.3302 \\
4047 \\
3968\end{array}$ \\
\hline 1995 & & & 968 & 2091 & & 230 & 3289 & 2921 \\
\hline 1996 & & & & 1967 & & 230 & 2197 & 1913 \\
\hline 1997 & & & & 1967 & & 230 & 2197 & 1875 \\
\hline 2998 & & & & 1967 & & 230 & 2197 & $193 \theta$ \\
\hline 1999 & & & & 1967 & & 230 & 2197 & 1902 \\
\hline 20100 & & & & 1967 & & 230 & 2197 & 1767 \\
\hline 2001 & & & & 1967 & & 230 & 2197 & 1732 \\
\hline 2002 & & & & 1967 & & 230 & 2197 & 1690 \\
\hline 2003 & & & & 2214 & & 230 & 2444 & 1852 \\
\hline 2004 & & & & 2214 & & 230 & 2444 & 1816 \\
\hline 2005 & & & & 2214 & & 230 & 2444 & 1780 \\
\hline 2006 & & & & $6847 *$ & & 230 & 7077 & 5054 \\
\hline TOTAL & 22568 & 5859 & 5810 & 34884 & 3780 & 4140 & 77041 & 67914 \\
\hline
\end{tabular}

* - DECOMmissioning COSt

INITIAL FAYMENT - 376 */KGU (INCLUDES \$/KgU IMFACT AID)

FINAL PAYMENT - 347 KGU (INCLUDES * 10/KgU IMPACT AID) 
TABLE A10-15

COST SENSITIVITY CASE - $\$ 3,500$ CANISTER

ESTIMATED SPENDING SCHEDULE FOR STORAGE OF 4478 DRYWELLS ( 1900 MTU) AT GOVERNMENT SITE WITHOUT EXISTING FACILITIES

$(\$ 000,1989)$

\begin{tabular}{|c|c|c|c|c|c|c|c|c|}
\hline YEAR & $\begin{array}{l}\text { TRANS } \\
\text { FACIL } \\
\text { COSTS }\end{array}$ & $\begin{array}{l}\text { STOR } \\
\text { AREA } \\
\text { COSTS }\end{array}$ & $\begin{array}{r}\text { MODULE } \\
\text { COSTS }\end{array}$ & $\begin{array}{r}\text { QPERAT } \\
\text { COSTS }\end{array}$ & $\begin{array}{l}\text { FIg } \\
\text { DEVEL } \\
\text { COSTB }\end{array}$ & $\begin{array}{l}\text { GOUT. } \\
\text { ADMIN } \\
\text { COSTS }\end{array}$ & $\begin{array}{l}\text { TOTAL, } \\
\text { COSTS }\end{array}$ & $\begin{array}{l}\text { DISC. } \\
\text { TDTAL } \\
\text { COSTS }\end{array}$ \\
\hline $\begin{array}{l}1989 \\
1990 \\
1991 \\
1992 \\
1993 \\
1994 \\
1995 \\
1996 \\
1997 \\
1998 \\
1999\end{array}$ & $\begin{array}{r}3654 \\
249 \\
9395 \\
9270\end{array}$ & $\begin{array}{r}2260 \\
155 \\
3509 \\
3432\end{array}$ & $\begin{array}{l}19492 \\
39994 \\
38964 \\
19492\end{array}$ & $\begin{array}{l}3050 \\
7699 \\
7699 \\
5501 \\
3303 \\
3303 \\
3303 \\
3303\end{array}$ & $\begin{array}{r}630 \\
1260 \\
1260 \\
630\end{array}$ & $\begin{array}{l}900 \\
900 \\
900 \\
900 \\
900 \\
900 \\
900 \\
900 \\
900 \\
900 \\
900\end{array}$ & $\begin{array}{r}7444 \\
2564 \\
15064 \\
37574 \\
47583 \\
47583 \\
25993 \\
4203 \\
4203 \\
4203 \\
4203\end{array}$ & $\begin{array}{r}7444 \\
2514 \\
14479 \\
35407 \\
43959 \\
43097 \\
22992 \\
3659 \\
3597 \\
3517 \\
3446\end{array}$ \\
\hline $\begin{array}{l}2000 \\
2001\end{array}$ & & & & $\begin{array}{l}3303 \\
3303\end{array}$ & & $\begin{array}{l}900 \\
900\end{array}$ & $\begin{array}{l}4203 \\
4203\end{array}$ & $\begin{array}{l}3390 \\
3314\end{array}$ \\
\hline $\begin{array}{l}2001 \\
2002\end{array}$ & & & & $\begin{array}{l}3303 \\
3303\end{array}$ & & $\begin{array}{l}700 \\
900\end{array}$ & 4203 & 3249 \\
\hline 2003 & & & & 7699 & & 900 & 6599 & 6517 \\
\hline $\begin{array}{l}2004 \\
2005\end{array}$ & & & & $\begin{array}{l}7699 \\
7699\end{array}$ & & $\begin{array}{l}900 \\
900\end{array}$ & $\begin{array}{l}8599 \\
8599\end{array}$ & $\begin{array}{l}6389 \\
6264\end{array}$ \\
\hline 2006 & & & & 297751 & & 800 & 30675 & 21907 \\
\hline TOTAL & 22568 & 9356 & 116952 & $\overline{100742}$ & 3780 & 16200 & $\overline{269598}$ & $\overline{235123}$ \\
\hline
\end{tabular}

* - DECOMMISSIONING COST

INITIAL, PAYMENT = $81 * / \mathrm{KgU}$ (INCLUDES $\$ / \mathrm{KgU}$ IMPACT AID)

FIMAL PAYMENT - 61 MKQU (INCLUDES $9 / \mathrm{KOU}$ IMPACT AID)

TABLE A10-16

COST SENSITIV!TY CASE - $\$ 2,000$ CANISTER

ESTIMATED SFENDING SCHEDULE FDR STOFAGE OF 4478 DFYWELLS ( 1900 MTU)

AT GOVEFNMENT SITE WITHOUT EXISTING FACILITIES

$(\$ 000,1989)$

\begin{tabular}{|c|c|c|c|c|c|c|c|c|}
\hline YEAR & $\begin{array}{l}\text { TKANS } \\
\text { FACIL } \\
\text { COSTS }\end{array}$ & $\begin{array}{l}\text { STOR } \\
\text { AREA } \\
\text { COSTS }\end{array}$ & $\begin{array}{r}\text { MODULE } \\
\text { COSTS }\end{array}$ & $\begin{array}{r}\text { OFEFAT } \\
\text { COSTS }\end{array}$ & $\begin{array}{l}\text { FIS } \\
\text { DEVEL } \\
\text { COSTS }\end{array}$ & $\begin{array}{l}\text { GOUT, } \\
\text { ADMIN } \\
\text { COSTS }\end{array}$ & $\begin{array}{l}\text { TOTAL } \\
\text { COSTS }\end{array}$ & $\begin{array}{l}\text { DISC. } \\
\text { TOTAL } \\
\text { COSTS }\end{array}$ \\
\hline $\begin{array}{l}1999 \\
1990 \\
1991\end{array}$ & $\begin{array}{r}3654 \\
249 \\
9395\end{array}$ & $\begin{array}{r}2260 \\
155 \\
3909\end{array}$ & & & $\begin{array}{r}630 \\
1260 \\
1260\end{array}$ & $\begin{array}{l}900 \\
900 \\
900\end{array}$ & $\begin{array}{r}7444 \\
2564 \\
15064\end{array}$ & $\begin{array}{r}7444 \\
2514 \\
14479\end{array}$ \\
\hline $\begin{array}{l}1992 \\
1993\end{array}$ & 5270 & 3432 & $\begin{array}{l}18372 \\
36745\end{array}$ & $\begin{array}{l}3850 \\
7699\end{array}$ & 630 & $\begin{array}{l}900 \\
900\end{array}$ & $\begin{array}{l}36454 \\
45344\end{array}$ & $\begin{array}{l}34351 \\
41891\end{array}$ \\
\hline 1994 & & & 36745 & 7099 & & 900 & 45344 & 41069 \\
\hline 1995 & & & 18372 & 5501 & & 900 & 24773 & 21990 \\
\hline 1990 & & & & 3303 & & 900 & 4203 & 3659 \\
\hline 1997 & & & & 3303 & & 900 & 4203 & 3597 \\
\hline 1998 & & & & 3303 & & 900 & 4203 & 3517 \\
\hline 1999 & & & & 3.303 & & 900 & 4203 & $344 \theta$ \\
\hline 2000 & & & & 3303 & & 900 & 4203 & 3380 \\
\hline 2001 & & & & 3303 & & 900 & 4203 & 3314 \\
\hline 2002 & & & & 3303 & & 900 & 4203 & 3249 \\
\hline 2003 & & & & 7699 & & 900 & 8599 & 6517 \\
\hline 2004 & & & & 7699 & & 900 & 8599 & 6.399 \\
\hline 2005 & & & & 7699 & & 900 & 8599 & 6264 \\
\hline 2006 & & & & $28432 *$ & & 900 & 29332 & 20948 \\
\hline TOTAL & 22568 & 9356 & 110234 & 99399 & 3780 & 16200 & $\overline{261537}$ & $\overline{220018}$ \\
\hline
\end{tabular}

* - decommissioning COST

INITIAL FAYMENT = 77 \$ KU (INCLUDES * 4/KgU IMFACT AID)

FINAL PAYMENT = 61 KGU (INCLUDES $\$ / K g U$ IMPACT AID) 


\subsection{IMPACT OF SCHEDULE CHANGES}

The impact on FIS costs of extending the FIS program by 2 years and by 5 years as a result of a delay in repository startup (past the 2003 date set forth in the Draft 1988 Mission Plan Amendment) is shown in Table A10-17.

TABLE A10-17

IMPACT OF EXTENDING THE TERM OF THE FIS PROGRAM

ON FIS SYSTEM COSTS

Year of

Completion of

FIs Activities

New Transfer Facility Cases

2005 (Base Case)

2007

2010

Increase-per yr. of delay

Existing Transfer Facility

Cases

2005 (Base Case)

2007

2010

Increase-per yr. of delay

\begin{tabular}{cc}
$\frac{100 \mathrm{MTU}}{\text { Total }}$ & Total \\
Discounted & Unit \\
Cost $(\$ 000)$ & Cost $(\$ / \mathrm{kgU})$ \\
\hline
\end{tabular}

$\$ 68,659$

71,544

75,664

1,401

$\$ 48,775$

50,572

53,137

872

$\frac{1900 \text { MTU }}{\begin{array}{cc}\text { Total } \\ \text { Discounted }\end{array} \begin{array}{c}\text { Total } \\ \text { Unit }\end{array}}$

Cost $(\$ 000) \quad$ Cost $(\$ / \mathrm{kgU})$

$\$ 242,158 \quad \$ 146$

$246,834 \quad 148$

$253,511 \quad 153$

2,271

$\$ 131$

132

135

1,303

The estimated spending schedules, discounted annual costs, and the calculation of the Initial and Final Payments for FIS of spent fuel for each of the cases considered in Table A10-17 are set forth in Tables A10-18 through Al0-25. 
TABLE AI0-18

COST SENSITIVITY CASE - - 2-YEAR EXTENSION OF FIS PROGRAM

ESTIMATED SPENDIMG SCHEDURE FOR STORAGE OF 236 DRYWELLS ( 100 MTU) AT GOVERMAENT SITE WITHOUT EXISTING FACILITIES

$(1000,1989)$

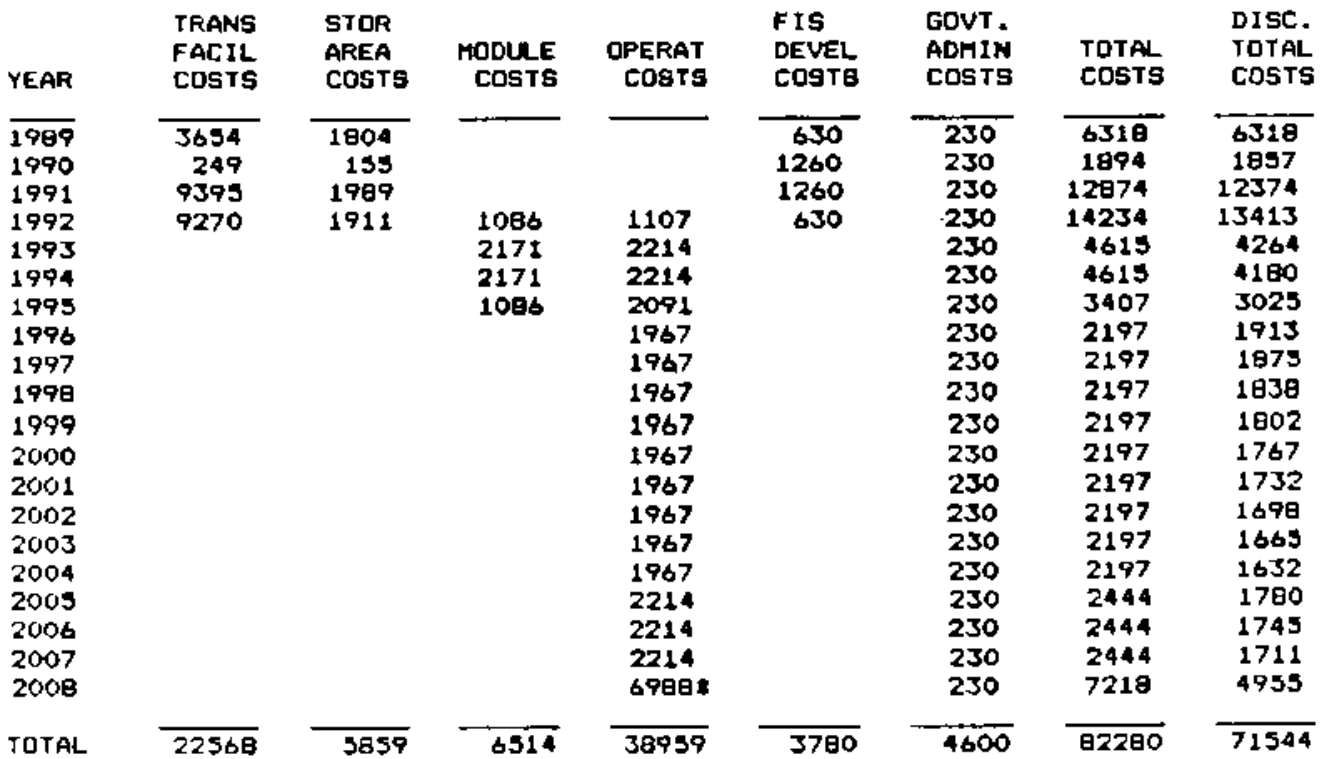

* - Decommissioning cost

INITIAL PAYMENT $=382 * / K g U$ (INCLUDES $* 5 / K g U$ IMPACT AID)

FINAL PAYMENT - 379 KgU (INCLUDES $10 / \mathrm{KgU}$ IMPACT AID)

TABLE AIO-19

COST SENSITIVITY CASE - - 5-YEAR EXTENSION OF FIS PROGRAM

EST IMATED SFENDING SCHEDULE FOR STORAGE OF 236 ORYWELLS ( 100 MTU) AT GOVERNAENT SITE WITHOUT EXISTING FACILITIEQ

$(1000,1989)$

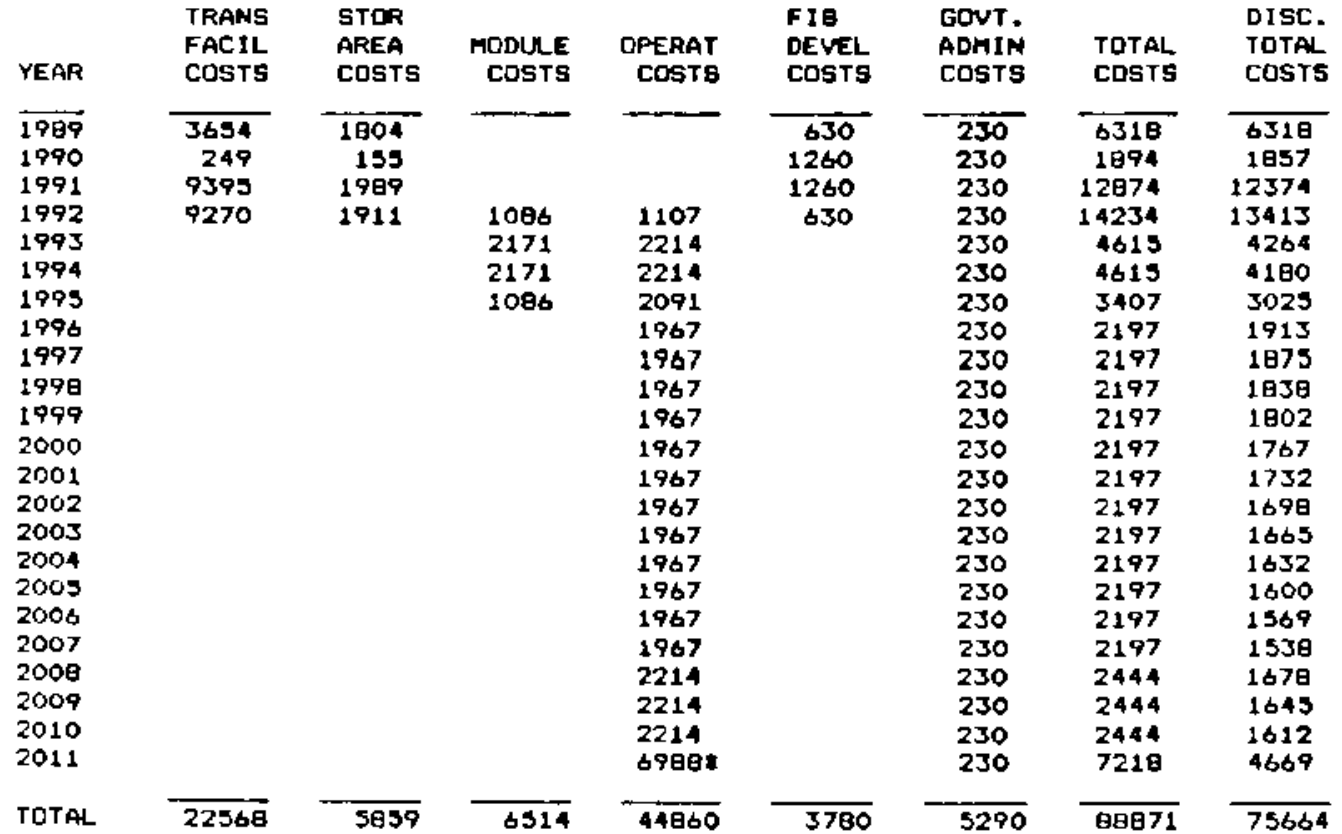

- Decommissioning cost

INITIAL PAYMENT = $382, / K g U$ (INCLLDES $\$ / K g$ I IMPACT AID)

FINAL PAYMENT = 424 MKU (INCLUDES $10 / \mathrm{KgU}$ IMPACT AID) 
TABLE A10-20

COST SENSITIVITY CASE -- 2-YEAR EXTENSION OF FIS PROGRAM

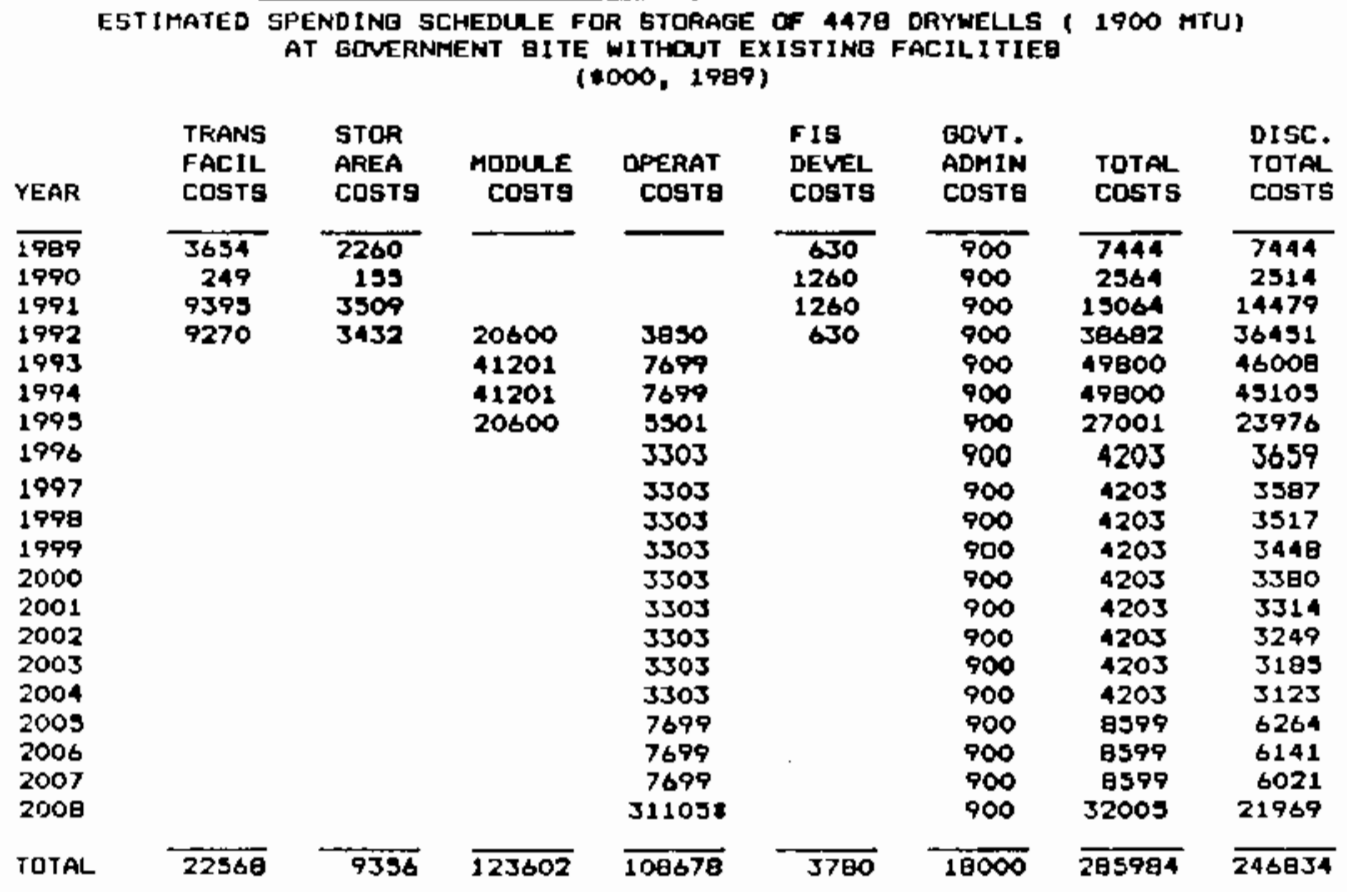

* Decommissioning cost

INITIAL PAYMENT - 84 *KGU (INCLUDES $\$$ S/KoU IMPACT AID)

FINAL PAYMENT - G4 KKOU (IMCLUDES $\$ / K$ UU IMPACT AID)

TABLE A10-21

COST SENSITIVITY CASE -. 5. YEAR EXTENSION OF FIS PROGRAM

ESTIMATED SPENDING SCHEDLRE FOR STORAEE OF 4478 DRYHELLS ( 1900 MTU)

AT GOVERNMENT SITE WITHOUT EXISTINO FACILITIES

$(\$ 000,1989)$

\begin{tabular}{|c|c|c|c|c|c|c|c|c|}
\hline YEAR & $\begin{array}{l}\text { TRANS } \\
\text { FACIL } \\
\text { COSTS }\end{array}$ & $\begin{array}{l}\text { STOR } \\
\text { AREA } \\
\text { COSTS }\end{array}$ & $\begin{array}{l}\text { MODULE } \\
\text { COSTS }\end{array}$ & $\begin{array}{c}\text { OPERAT } \\
\text { CDSTE }\end{array}$ & $\begin{array}{l}\text { FIS } \\
\text { DEVEL, } \\
\text { COSTS }\end{array}$ & $\begin{array}{l}\text { GONT. } \\
\text { ADMIN } \\
\text { COSTS }\end{array}$ & $\begin{array}{l}\text { TOTAL } \\
\text { COSTS }\end{array}$ & $\begin{array}{l}\text { DISC. } \\
\text { TOTAL } \\
\text { CDSTS }\end{array}$ \\
\hline $\begin{array}{l}1989 \\
1990 \\
1991 \\
1992 \\
1993 \\
1994 \\
1995 \\
1996 \\
1997 \\
1998 \\
1999 \\
2000 \\
2001 \\
2002 \\
2003 \\
2004 \\
2005 \\
2006 \\
2007 \\
2008 \\
2009 \\
2010 \\
2011\end{array}$ & $\begin{array}{r}3654 \\
249 \\
9395 \\
9270\end{array}$ & $\begin{array}{r}2260 \\
135 \\
3509 \\
3432\end{array}$ & $\begin{array}{l}20800 \\
41201 \\
11201 \\
20 \Delta 00\end{array}$ & $\begin{array}{l}3950 \\
7699 \\
7699 \\
9501 \\
3303 \\
3303 \\
3303 \\
3303 \\
3303 \\
3303 \\
3303 \\
3303 \\
3303 \\
3303 \\
3303 \\
3303 \\
7699 \\
7699 \\
7699 \\
311034\end{array}$ & $\begin{array}{r}630 \\
1260 \\
1260 \\
630\end{array}$ & $\begin{array}{l}900 \\
900 \\
900 \\
900 \\
900 \\
900 \\
900 \\
900 \\
900 \\
900 \\
900 \\
900 \\
900 \\
900 \\
900 \\
900 \\
900 \\
900 \\
900 \\
900 \\
900 \\
900 \\
900\end{array}$ & $\begin{array}{r}7444 \\
2564 \\
15064 \\
38682 \\
49800 \\
49800 \\
27001 \\
4203 \\
4203 \\
4203 \\
4203 \\
4203 \\
4203 \\
4203 \\
4203 \\
4203 \\
4203 \\
4203 \\
4203 \\
8599 \\
9599 \\
8599 \\
32005\end{array}$ & $\begin{array}{r}7444 \\
2514 \\
14479 \\
36451 \\
46008 \\
45105 \\
23976 \\
3659 \\
3587 \\
3517 \\
3449 \\
3390 \\
3314 \\
3249 \\
3195 \\
3123 \\
3062 \\
3002 \\
2943 \\
5903 \\
5797 \\
5673 \\
20702\end{array}$ \\
\hline TOTAL & 22560 & 9356 & $\overline{123602}$ & $\overline{118987}$ & 3780 & 20700 & 290593 & 253511 \\
\hline
\end{tabular}

* - decommissianing cost

INITIAL PAYMENT = $84 / \mathrm{KgU}$ (INCLUDES $\$ / K g U$ IMPACT AID)

FINAL PAYMENT - 69 \$KGU (IMCLUDES $\$ 10 / \mathrm{KgU}$ IMPACT AID) 
TABLE A10-22

COST SENSITIVITY CASE $\cdots 2$ 2-YEAR EXTENSION OF FIS PROGRAH

ESTIMATED SPENOING SCHEDULE FOR STORAGE OF 236 DRYWELLS ( 100 MTU)

AT GOVERNMENT SITE WITH EXISTINE FACILITIES

$(\$ 000,1989)$

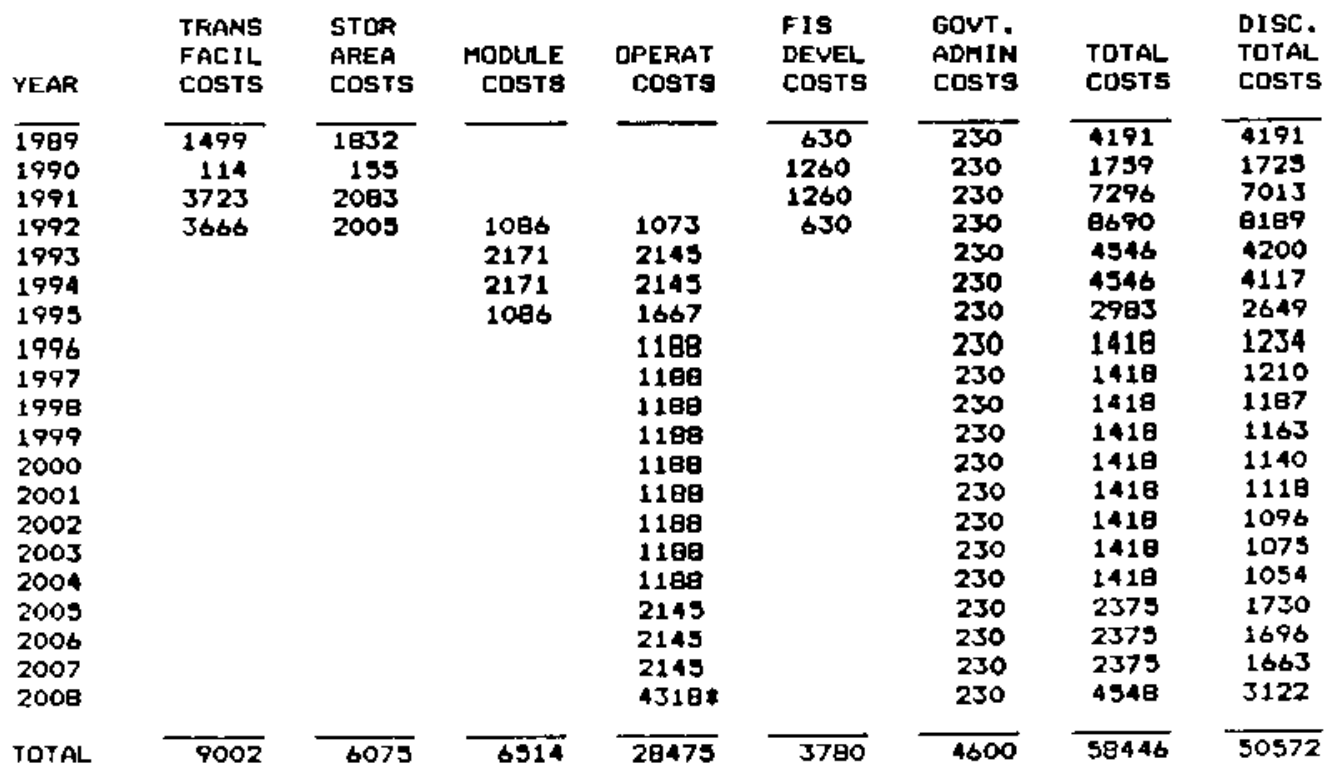

* - DECOMMISSIONING CDST

INITIAL PAYMENT = 253 * KOU (INCLUDES $\$ / \mathrm{KgU}$ IMPACT AID)

FINAL PAYMENT - 292 SKgU (INCLUDES $10 / \mathrm{KgU}$ IMPACT AID)

TABLE A10-23

COST SENSITIVITY CASE -- 5-YEAR EXTENSION OF FIS PROGRAM

EST IMATED SPENDING SCHEDULE FOR STORAGE OF 236 DRYWELLS ( 100 MTU) AT GOVERNMENT SITE WITH EXISTING FACILITIES

$(\$ 000,1989)$

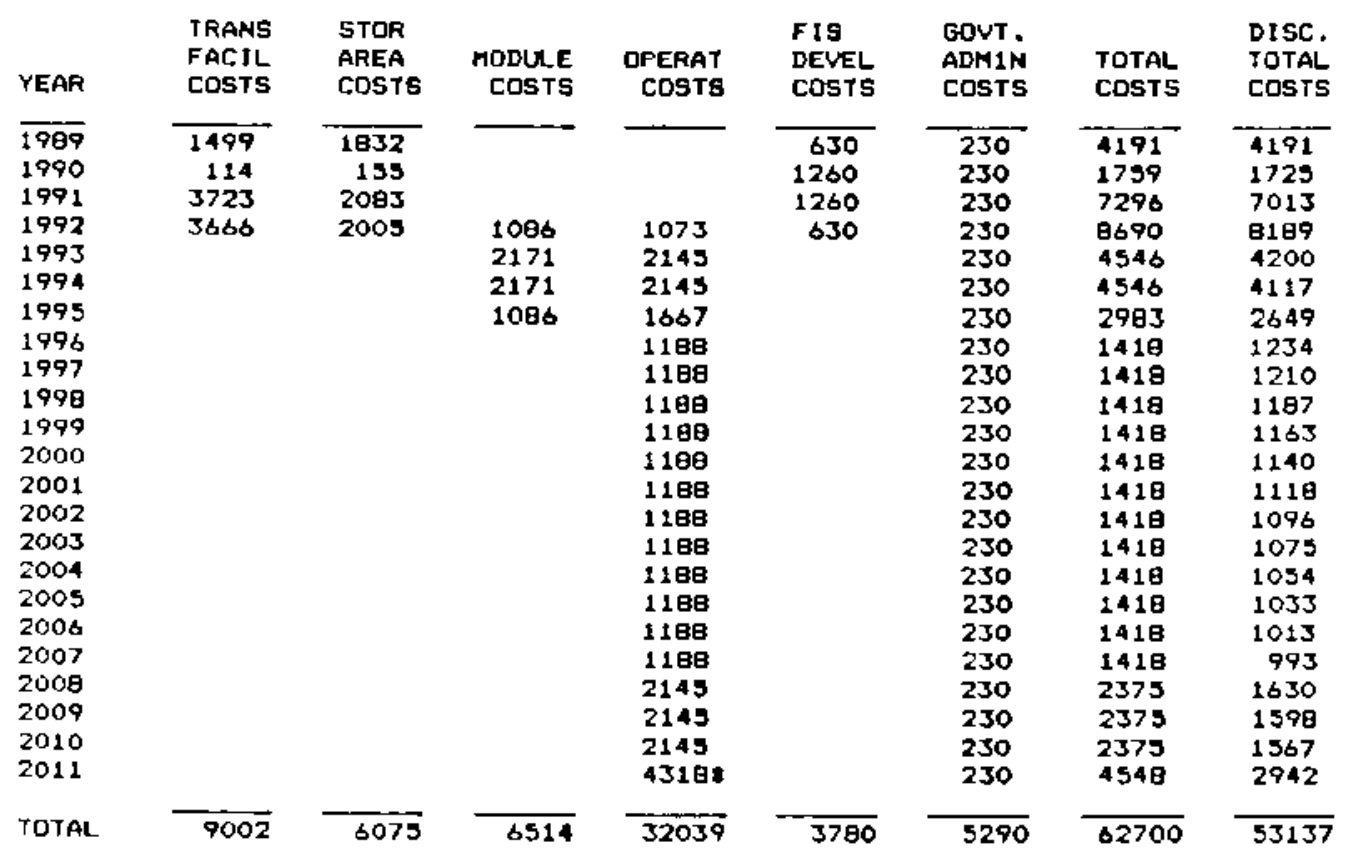

* - DECOMmissioning COST

INITIAL PAYMENT = 253 \$KgL (INCLUDES $\$ / K g U$ IMPACT AID)

FINAL PAYMENT * 320 KoU (INCLUDES $10 / \mathrm{Kg}$ IMPACT AID) 
TABLE A10-24

COST SENSITIVITY CASE - - 2-YEAR EXTENSION OF FIS PROGRAH

ESTIMATED SPENDING SCHEDULE FOR STORAGE OF 4479 DRYWELLS ( 1900 MTU)

AT GOVERNMENT SITE WITH EXISTING FACILITIES

$(1000,1989)$

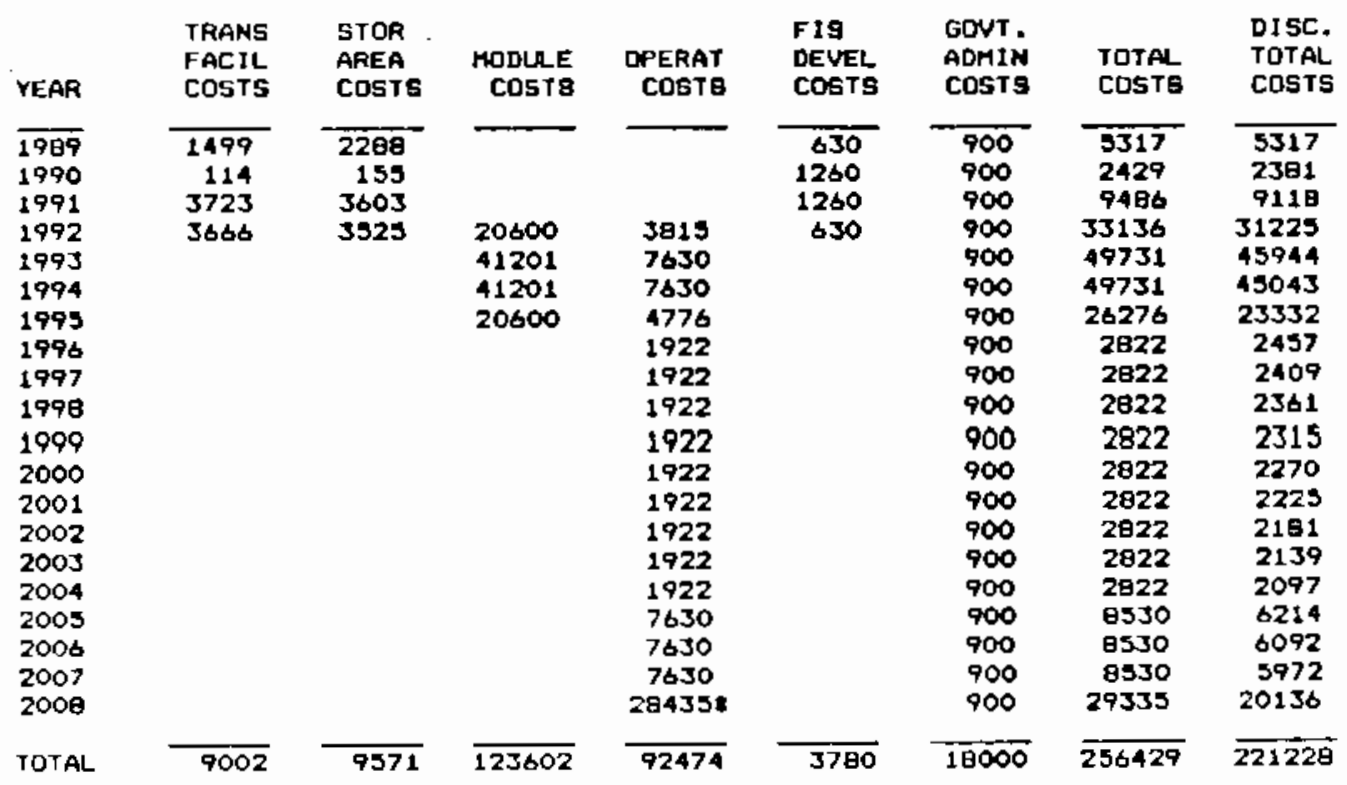

* oecommissioning cost

INITIAL PAYMENT * 76 *KgU (INCLUDEs * 4/KgU IMPACt AID)

FINAL PAYMENT - SO KKU (INCLUDES * B/KgU IMPACT AID)

IABLE A10-25

COST SENSITIVITY CASE - 5-YEAR EXTENSION OF FIS PROGRAK

ESTIMATED SPENDING SCHEDLLE FOR STORAGE OF 4478 DRYWELLS (1900 MTU) AT GDVERNMENT SITE WITH EXISTINO FACILITIES

$(2000,1909)$

\begin{tabular}{|c|c|c|c|c|c|c|c|c|}
\hline YEAR & $\begin{array}{l}\text { TRANS } \\
\text { FACIL } \\
\text { COSTS }\end{array}$ & $\begin{array}{l}\text { STOR } \\
\text { AREA } \\
\text { COSTS }\end{array}$ & $\begin{array}{r}\text { MODULEE } \\
\text { CDSTS }\end{array}$ & $\begin{array}{r}\text { CPERAT } \\
\text { CDSTS }\end{array}$ & $\begin{array}{l}\text { FIS } \\
\text { DEVEL } \\
\text { CDSTS }\end{array}$ & $\begin{array}{l}\text { GOVT. } \\
\text { AOMIN } \\
\text { COSTS }\end{array}$ & $\begin{array}{l}\text { IOTAL } \\
\text { COSTS }\end{array}$ & $\begin{array}{l}\text { OISC. } \\
\text { TOTAL } \\
\text { COSTS }\end{array}$ \\
\hline $\begin{array}{l}19 \overline{199} \\
1990\end{array}$ & $\begin{array}{r}1499 \\
114\end{array}$ & $\begin{array}{r}2280 \\
153\end{array}$ & & & $\begin{array}{r}630 \\
1260\end{array}$ & $\begin{array}{l}900 \\
900\end{array}$ & $\begin{array}{l}3317 \\
2429\end{array}$ & $\begin{array}{l}5317 \\
2301\end{array}$ \\
\hline 1991 & 3723 & 3603 & & & 1260 & 900 & 9486 & 9110 \\
\hline 1992 & 3666 & 3525 & 20600 & 3815 & 630 & 700 & 35136 & 31225 \\
\hline 1993 & & & 41201 & 7630 & & 900 & 49731 & 45744 \\
\hline 1994 & & & 41201 & 7630 & & 900 & 49731 & 45043 \\
\hline 1995 & & & 20600 & 4776 & & 900 & 26276 & 23332 \\
\hline 1996 & & & & 1922 & & 900 & $2 \theta 22$ & 2457 \\
\hline 1997 & & & & 1922 & & 900 & 2822 & 2409 \\
\hline 1998 & & & & 1922 & & 900 & 2822 & 2361 \\
\hline 1999 & & & & 1922 & & 900 & 2922 & 2313 \\
\hline 2000 & & & & 1922 & & 900 & 2822 & 2270 \\
\hline 2001 & & & & 1922 & & 900 & 2822 & 2223 \\
\hline 2002 & & & & 1922 & & 900 & 2822 & 2181 \\
\hline 2003 & & & & 1922 & & 900 & 2822 & 2139 \\
\hline 2004 & & & & 1922 & & 900 & 2822 & 2097 \\
\hline 2005 & & & & 1922 & & 900 & 2822 & 2056 \\
\hline 2006 & & & & 1922 & & 900 & 2922 & 2015 \\
\hline 2007 & & & & 1922 & & 900 & 2822 & 1976 \\
\hline 2000 & & & & 7630 & & 900 & 0530 & 5855 \\
\hline 2009 & & & & 7630 & & 900 & 8530 & 5740 \\
\hline 2010 & & & & 7630 & & 900 & 8530 & 5628 \\
\hline 2011 & & & & $28435 \%$ & & 900 & 29335 & 18973 \\
\hline TOTAL & 9002 & 9571 & 123602 & 98240 & 3700 & 20700 & 264095 & 225059 \\
\hline
\end{tabular}

- Decomaissioning Cost

INITIAL FAYMENT = 76 /KgU (INCLUDES $4 / \mathrm{KgU}$ IMPACT AID)

FINAL PAYMENT = $39 \mathrm{KKgU}$ (INCLUDES $9 / \mathrm{KgU}$ IMPACT AID)

A $10-14$ 
The impact on FIS costs of spreading the time for receipt of spent fuel at the FIS facility from the 3-year period set forth in Section 3.4 to a total of 4 years and 5 years, respectively, is shown in Table A10-26.

TABLE A10-26

IMPACT OF SPREADING THE TIME FDR RECEIPTS OF SPENT FUEL

AT FIS FACILITIES ON FIS SYSTEM COSTS

Number of Years

Spent Fuel Received

New Transfer Facility

Cases

3 yrs. (Base Case)

4 yrs.

5 yrs.

Change per yr. of receipt time

Existing Transfer Facility Cases

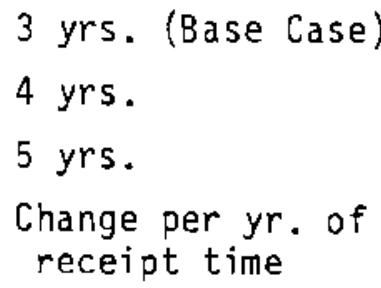

\begin{tabular}{cccc}
$\frac{100}{c}$ & & \multicolumn{2}{c}{1900 MTU } \\
\cline { 3 - 4 } Total & Total & Total & Total \\
Discounted & Unit & Discounted & Unit \\
Cost $(\$ 000)$ & Cost $(\$ / \mathrm{kgU})$ & Cost $(\$ 000)$ & Cost $(\$ / \mathrm{kgU})$ \\
\hline
\end{tabular}

$\$ 68,659$

$\$ 730$

$\$ 242,158$

$\$ 146$

68,594

733

239,965

146

68,534

735

237,810

144

$-62$

$+2$

$-2,174$

$+1$

$\$ 48,775$

$\$ 525$

49,334

534

$\$ 218,545$

$\$ 131$

49,888

543

217,507

131

$+557$

$+9$

The estimated spending schedules, discounted annual costs, and the calculation of the Initial and Final Payments for FIS of spent fuel for each of the cases considered in Table Al0-26 are set forth in Tables A10-27 through A10-34. 
TABLE A $10-27$

COST SENSITIVITY CASE - - 4-YEAR RECEIPT OF SPENT FUEL

EST IMATED SFENDING SCHEDLLE FOR STORAGE DF 236 DRYWELLS ( 100 MTU)

AT GOVERNMENT SITE WITHOUT EXISTING FACILITIES

$(1000,1989)$

\begin{tabular}{|c|c|c|c|c|c|c|c|c|}
\hline YEAR & $\begin{array}{l}\text { TFANS } \\
\text { FACIL } \\
\text { COSTS }\end{array}$ & $\begin{array}{l}\text { STUR } \\
\text { AREA } \\
\text { COSTS }\end{array}$ & $\begin{array}{l}\text { MODULE } \\
\text { COSTS }\end{array}$ & $\begin{array}{r}\text { DPERAT } \\
\text { COSTG }\end{array}$ & $\begin{array}{l}\text { FIS } \\
\text { DEVEL } \\
\text { COSTS }\end{array}$ & $\begin{array}{l}\text { GDVT. } \\
\text { ADMIN } \\
\text { COSTS }\end{array}$ & $\begin{array}{l}\text { TOTAL } \\
\text { COSTS }\end{array}$ & $\begin{array}{l}\text { DISC. } \\
\text { TOTAL } \\
\text { COSTS }\end{array}$ \\
\hline $\begin{array}{l}1989 \\
1990 \\
1991 \\
1992 \\
1993 \\
1994 \\
1995 \\
1996 \\
1997 \\
1998 \\
1999 \\
2000 \\
2001 \\
2002 \\
2003 \\
2004 \\
2005 \\
2006\end{array}$ & $\begin{array}{r}3654 \\
249 \\
9395 \\
9270\end{array}$ & $\begin{array}{r}1804 \\
153 \\
1989 \\
1911\end{array}$ & $\begin{array}{r}814 \\
1629 \\
1629 \\
1629 \\
814\end{array}$ & $\begin{array}{l}1076 \\
2152 \\
2152 \\
2152 \\
2060 \\
1967 \\
1967 \\
1967 \\
1967 \\
1967 \\
1967 \\
2214 \\
2214 \\
2214 \\
6989\end{array}$ & $\begin{array}{r}630 \\
1260 \\
1260 \\
630\end{array}$ & $\begin{array}{l}230 \\
230 \\
230 \\
230 \\
230 \\
230 \\
230 \\
230 \\
230 \\
230 \\
230 \\
230 \\
230 \\
230 \\
230 \\
230 \\
230 \\
230\end{array}$ & $\begin{array}{r}6319 \\
1894 \\
12874 \\
13931 \\
4011 \\
4011 \\
4011 \\
3104 \\
2197 \\
2197 \\
2197 \\
2197 \\
2197 \\
2197 \\
2444 \\
2444 \\
2444 \\
7218\end{array}$ & $\begin{array}{r}6318 \\
1857 \\
12374 \\
13127 \\
3706 \\
3633 \\
3562 \\
2702 \\
1875 \\
1939 \\
1802 \\
1767 \\
1732 \\
1690 \\
1852 \\
1816 \\
1780 \\
5155\end{array}$ \\
\hline
\end{tabular}

* - decomissioning cost

INITIAL PAYMENT $=382 \% / \mathrm{KgU}$ (INCLUDES $\$ / \mathrm{KOU}$ IMPACT AID)

FINAL PAYMENT - 351 KOU (INCLUDES $10 / \mathrm{KgU}$ IMPACT AID)

TABLE A10-28

COST SENSITIVITY CASE -. S-YEAR RECEIPT OF SPENT FUEL

ESTIMATED SPENDING SCHEDULE FOR STORAGE OF 236 DRYWELLS ( 100 MTU) AT GOVEFNMENT SITE WITHDUT EXISTING FACILITIES

$(\$ 000,1989)$

\begin{tabular}{|c|c|c|c|c|c|c|c|c|}
\hline YEAR & $\begin{array}{l}\text { TRANS } \\
\text { FACIL } \\
\text { COSTS }\end{array}$ & $\begin{array}{l}\text { STOR } \\
\text { AREA } \\
\text { COSTS }\end{array}$ & $\begin{array}{r}\text { MODULE } \\
\text { COSTS }\end{array}$ & $\begin{array}{r}\text { DPERAT } \\
\text { COSTS }\end{array}$ & $\begin{array}{l}\text { FIS } \\
\text { DEVEL } \\
\text { COSTS }\end{array}$ & $\begin{array}{l}\text { GOVT. } \\
\text { ADMIN } \\
\text { COSTS }\end{array}$ & $\begin{array}{l}\text { TOTAL, } \\
\text { COSTS }\end{array}$ & $\begin{array}{l}\text { DISC. } \\
\text { TOTAL } \\
\text { COSTS }\end{array}$ \\
\hline 1991 & 9395 & 1999 & & & 1260 & 230 & 12874 & 12374 \\
\hline 1992 & 9270 & 1911 & 651 & 1058 & 630 & 230 & 13750 & 12957 \\
\hline 1993 & & & 1303 & 2116 & & 230 & 3649 & 3371 \\
\hline 1994 & & & 1303 & 2116 & & 230 & 3649 & 3305 \\
\hline 1995 & & & 1303 & 2116 & & 230 & 3649 & 3240 \\
\hline 1996 & & & 1303 & 2116 & & 230 & 3649 & 3177 \\
\hline 1997 & & & 651 & 2042 & & 230 & 2923 & 2495 \\
\hline 1998 & & & & 1967 & & 230 & 2197 & 1938 \\
\hline 1999 & & & & 1967 & & 230 & 2197 & 1802 \\
\hline 2000 & & & & 1967 & & 230 & 2197 & 1767 \\
\hline 2001 & & & & 1967 & & 230 & 2197 & 1732 \\
\hline 2002 & & & & 1967 & & 230 & 2197 & 2698 \\
\hline 2003 & & & & 2214 & & 230 & 2444 & 1852 \\
\hline 2004 & & & & 2214 & & 230 & 2444 & 1816 \\
\hline 2005 & & & & 2214 & & 230 & 2444 & 1780 \\
\hline 2006 & & & & $6980 *$ & & 230 & 7210 & 5155 \\
\hline TOTAL & 22568 & 5859 & $\overrightarrow{6514}$ & 35027 & 3780 & 4140 & 77890 & 68534 \\
\hline
\end{tabular}

* - Decommissioning cost

INITIAL PAYMENT - JBI */KQU (INCludes * 5/KgU IMPACt AID)

FINAL PAYMENT - 354 $\mathrm{KgU}$ (INCLUDES * 10/KgU IMPACT AID) 
TABLE A10-29

COST SENSITIVITY CASE :- 4-YEAR RECEIPT OF SPENT FUEL

ESTIMATED SPENDING SCHEDULE FOR STORAGE OF 4478 DRYWELLS ( 1900 MTU)

AT GOVERNMENT SITE WITHOUT EXISTING FACILITIES

$(\$ 000,1989)$

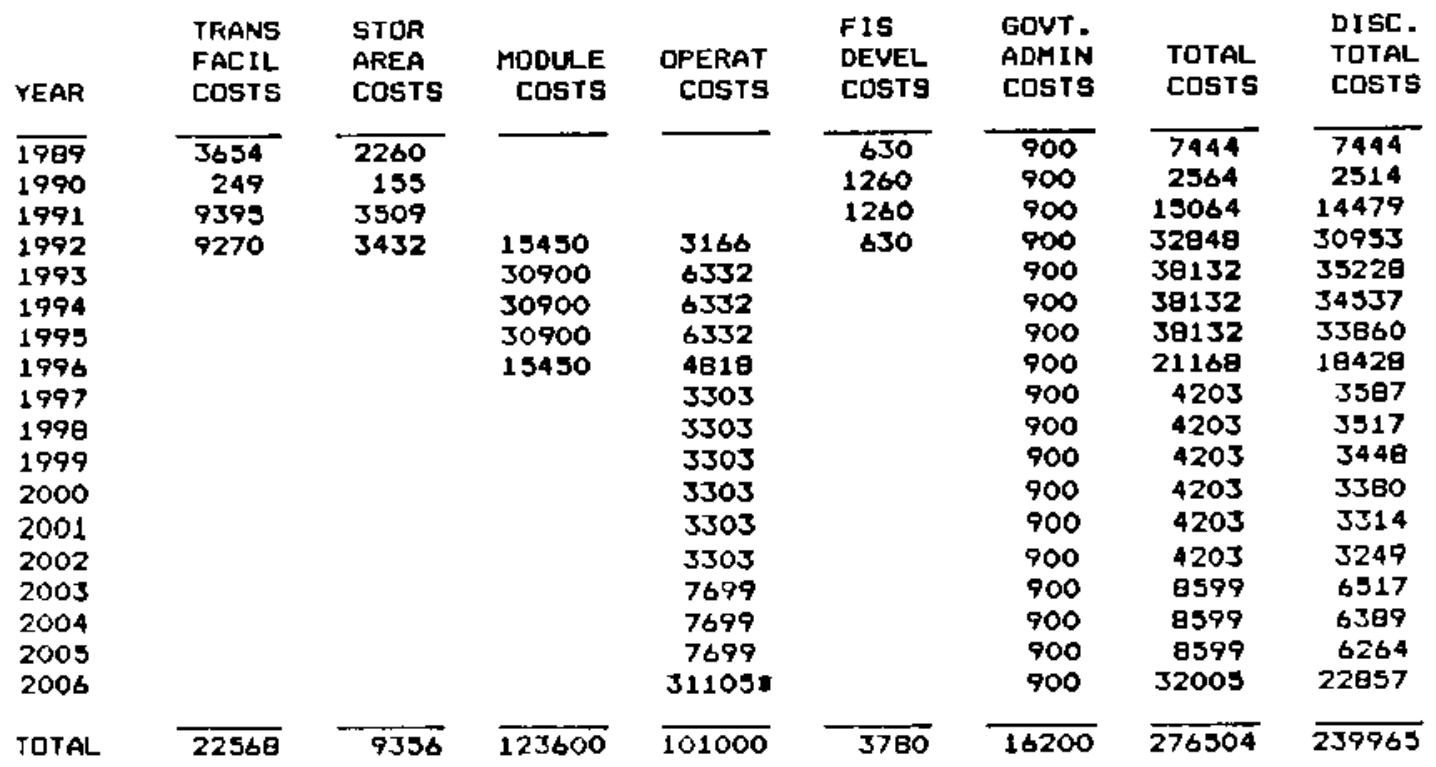

* Decommissioning COST

INITIAL PAYMENT = $B 4$ /KgU (INCLUDES $\$ / K g U$ IMPACT AID)

FINAL PAYMENT -62 MKgU (INCLUDES * $9 / \mathrm{KgU}$ IMPACT AID)

TABLE A10-30

COST SENSITIVITY CASE — S-YEAR RECEIPT OF SPENT FUEL

ESTIMATED SPENDING SCHEDULE FOR STDRAGE OF 4479 DRYWELLS ( $1900 \mathrm{MTU})$ AT GOVERNMENT SITE WITHOUT EXISTING FACILITIES

$(9000,1989)$

\begin{tabular}{|c|c|c|c|c|c|c|c|c|}
\hline YEAR & $\begin{array}{l}\text { TRANS } \\
\text { FACIL } \\
\text { COSTS }\end{array}$ & $\begin{array}{l}\text { STOR } \\
\text { AREA } \\
\text { COSTS }\end{array}$ & $\begin{array}{r}\text { MODULE } \\
\text { COSTS }\end{array}$ & $\begin{array}{r}\text { OPERAT } \\
\text { CDSTS }\end{array}$ & $\begin{array}{l}\text { FIS } \\
\text { DEVEL } \\
\text { COSTS }\end{array}$ & $\begin{array}{l}\text { GOVT. } \\
\text { ADHIN } \\
\text { COSTS }\end{array}$ & $\begin{array}{l}\text { TOTAL } \\
\text { COSTS }\end{array}$ & $\begin{array}{l}\text { DISC. } \\
\text { TOTAL } \\
\text { COSTS }\end{array}$ \\
\hline 1989 & 3654 & & & & & 900 & 7444 & 7444 \\
\hline $\begin{array}{l}1990 \\
1991\end{array}$ & $\begin{array}{r}249 \\
9395\end{array}$ & $\begin{array}{r}155 \\
3509\end{array}$ & & & $\begin{array}{l}1260 \\
1260\end{array}$ & $\begin{array}{l}900 \\
900\end{array}$ & $\begin{array}{r}2564 \\
15064\end{array}$ & $\begin{array}{r}2514 \\
14479\end{array}$ \\
\hline 1992 & 9270 & 3432 & $\begin{array}{l}12360 \\
24720\end{array}$ & 2736 & 630 & 900 & 29348 & $\begin{array}{l}27655 \\
28761\end{array}$ \\
\hline 1994 & & & 24720 & 5512 & & 900 & 31132 & 28197 \\
\hline 1995 & & & 24720 & 5512 & & 900 & 31132 & 27644 \\
\hline 1996 & & & 24720 & 5312 & & 900 & 31132 & 27102 \\
\hline 1997 & & & 12360 & 4400 & & 900 & 17668 & 15079 \\
\hline 1998 & & & & 3303 & & 900 & 4203 & 3517 \\
\hline 1997 & & & & 3.303 & & 900 & 4203 & 3448 \\
\hline 2000 & & & & 3303 & & 900 & 4203 & 3380 \\
\hline 2001 & & & & 3303 & & 900 & 4203 & 3314 \\
\hline 2002 & & & & 3303 & & 900 & 4203 & 3249 \\
\hline 2003 & & & & 7699 & & 900 & 6599 & 6517 \\
\hline 2004 & & & & 7679 & & 900 & 8599 & 6389 \\
\hline 2005 & & & & 7699 & & 900 & 8599 & 6264 \\
\hline 2006 & & & & $31105 t$ & & 900 & 32003 & 22857 \\
\hline TOTAL & 22568 & 9356 & 123600 & 99929 & 3700 & 16200 & $\overline{275433}$ & $\overline{237810}$ \\
\hline
\end{tabular}

* - Decommissioning cost

INITIAL PAYMENT = BJ /KgU (INCLUDES $\$$ /KgU IMPACT AID)

FINAL. PAYMENT - 61 \$KU (INCLUDES $\$$ \%/KQU IMPACT AID) 
TABLE A10-31

COST SENSITIVITY CASE -- 4-YEAR RECEIPT OF SPENT FUEL

ESTIMATED SPENDING SCHEDULE FOR STDRAGE OF 236 DRYWELLS ( 100 MTU) AT GOVERNMENT SITE WITH EXISTINB FACILITIES

$(\$ 000,1999)$

\begin{tabular}{|c|c|c|c|c|c|c|c|c|}
\hline YEAR & $\begin{array}{l}\text { IRANS } \\
\text { FACIL } \\
\text { COSTS }\end{array}$ & $\begin{array}{l}\text { STOR } \\
\text { AREA } \\
\text { COSTS }\end{array}$ & $\begin{array}{l}\text { MODULE } \\
\text { COSTS }\end{array}$ & $\begin{array}{r}\text { OPERAT } \\
\text { COSTS }\end{array}$ & $\begin{array}{l}\text { FIS } \\
\text { DEVEL } \\
\text { COSTS }\end{array}$ & $\begin{array}{l}\text { GDVT. } \\
\text { ADMIN } \\
\text { COSTS }\end{array}$ & $\begin{array}{l}\text { TOTAL } \\
\text { COSTS }\end{array}$ & $\begin{array}{l}\text { DISC. } \\
\text { TOTAL } \\
\text { COSTS }\end{array}$ \\
\hline $\begin{array}{l}1989 \\
1990 \\
1991 \\
1992 \\
1993 \\
1994 \\
1995 \\
1996 \\
1997 \\
1998 \\
1999 \\
2000 \\
2001 \\
2002 \\
2003 \\
2004 \\
2005 \\
2006\end{array}$ & $\begin{array}{r}1499 \\
114 \\
3723 \\
3666\end{array}$ & $\begin{array}{r}1832 \\
155 \\
2003 \\
2005\end{array}$ & $\begin{array}{r}814 \\
1629 \\
1629 \\
1629 \\
014\end{array}$ & $\begin{array}{l}1042 \\
2083 \\
2083 \\
2083 \\
1636 \\
1189 \\
1198 \\
1189 \\
1189 \\
1188 \\
1198 \\
2145 \\
2145 \\
2145 \\
4318\end{array}$ & $\begin{array}{r}630 \\
1260 \\
1260 \\
630\end{array}$ & $\begin{array}{l}230 \\
230 \\
230 \\
230 \\
230 \\
230 \\
230 \\
230 \\
230 \\
230 \\
230 \\
230 \\
230 \\
230 \\
230 \\
230 \\
230 \\
230\end{array}$ & $\begin{array}{l}4191 \\
1759 \\
7296 \\
6397 \\
3942 \\
3942 \\
3942 \\
2680 \\
1418 \\
1418 \\
1419 \\
1418 \\
1418 \\
1418 \\
2375 \\
2375 \\
2375 \\
4549\end{array}$ & $\begin{array}{l}4191 \\
1725 \\
7013 \\
7903 \\
3642 \\
3570 \\
3500 \\
2333 \\
1210 \\
1187 \\
1163 \\
1140 \\
1118 \\
1096 \\
1800 \\
1765 \\
1730 \\
3248\end{array}$ \\
\hline TOTAL. & 9002 & 6075 & 6515 & 26800 & 3780 & 4140 & 56320 & 49334 \\
\hline
\end{tabular}

t - DECOMMISSIDNING COST

INITIAL FAYMENT = $253 * \mathrm{KgU}$ (INCLUDES $5 / \mathrm{KgU}$ IMPACT AID)

FINAL PAYMENT - 281 KgU (INCLUDEs * 10/KgU IMPACT AID)

TABLE A10-32

COST SENSITIVITY CASE - - 5-YEAR RECEIPT OF SPENT FUEL

EST IMATED SPENDING SCHEDULE FOR STDRAGE OF 236 DRYWELLS ( 100 MTU) AT GOVERNMENT SITE WITH EXISTING FACILITIES

$(8000,1989)$

\begin{tabular}{|c|c|c|c|c|c|c|c|c|}
\hline YEAR & $\begin{array}{l}\text { TRANS } \\
\text { FACIL } \\
\text { COSTS }\end{array}$ & $\begin{array}{l}\text { STOR } \\
\text { AREA } \\
\text { COSTS }\end{array}$ & $\begin{array}{r}\text { MODULE } \\
\text { COSTS }\end{array}$ & $\begin{array}{r}\text { OPERAT } \\
\text { COSTS }\end{array}$ & $\begin{array}{l}\text { FIS } \\
\text { DEVEL } \\
\text { COSTS }\end{array}$ & $\begin{array}{l}\text { GDVT. } \\
\text { ADMIN } \\
\text { CDSTS }\end{array}$ & $\begin{array}{l}\text { TOTAL } \\
\text { CDSTS }\end{array}$ & $\begin{array}{l}\text { DISC. } \\
\text { TOTAL } \\
\text { COSTS }\end{array}$ \\
\hline $\begin{array}{l}1989 \\
1990 \\
1991\end{array}$ & $\begin{array}{r}1499 \\
114 \\
3723\end{array}$ & $\begin{array}{r}1832 \\
153 \\
2083\end{array}$ & & & $\begin{array}{r}630 \\
1260 \\
1260\end{array}$ & $\begin{array}{l}230 \\
230 \\
230\end{array}$ & $\begin{array}{l}4191 \\
1759 \\
7296\end{array}$ & $\begin{array}{l}4191 \\
1725 \\
7013\end{array}$ \\
\hline $\begin{array}{l}1991 \\
1992\end{array}$ & 3666 & 2005 & 651 & 1024 & 430 & 230 & $020 d$ & 7733 \\
\hline 2993 & & & 1303 & 2047 & & 230 & 3500 & 3307 \\
\hline 2994 & & & 1303 & 2047 & & 230 & 3580 & 3243 \\
\hline 1995 & & & 1303 & 2047 & & 230 & 3580 & 3179 \\
\hline 1996 & & & 1303 & 2047 & & 230 & 3380 & 3117 \\
\hline 1997 & & & 851 & 1618 & & 230 & 2499 & 2133 \\
\hline 1990 & & & & 1180 & & 230 & 1419 & 1187 \\
\hline 1999 & & & & $118 \theta$ & & 230 & 1419 & 1163 \\
\hline 2000 & & & & 1180 & & 230 & 1418 & 1140 \\
\hline 2001 & & & & 1100 & & 230 & 1418 & 1118 \\
\hline 2002 & & & & 1180 & & 230 & 1418 & 1096 \\
\hline 2003 & & & & 2145 & & 230 & 2375 & 1800 \\
\hline 2004 & & & & 2145 & & 230 & 2375 & 1765 \\
\hline 2005 & & & & 2145 & & 230 & 2375 & 1730 \\
\hline 2006 & & & & $4310 *$ & & 230 & 4548 & 3248 \\
\hline TOTAL & 9002 & 6075 & 6514 & 27523 & 3780 & 4140 & 57034 & $4988 \theta$ \\
\hline
\end{tabular}

* - Decdmissioning cost

INITIAL PAYMENT $=252 * / \mathrm{KgU}$ (INCLUDES $5 / \mathrm{KgU}$ IMPACT AID)

FINAL PAYMENT = 291 $1 \mathrm{KgU}$ (INCLUDES $10 / \mathrm{KgU}$ IMPACT AID) 
TABLE A10-33

COST SENSITIVITY CASE - - 4-YEAR RECEIPT OF SPENT FUEL

ESTIMATED SPENDING SCMEDULE FOR STORAGE OF 4479 DRYWELLS ( 1900 MTU)

AT GOVERNMENT SITE WITH EXISTING FACILITIES

$(0000,1989)$

\begin{tabular}{|c|c|c|c|c|c|c|c|c|}
\hline YEAR & $\begin{array}{l}\text { TRANS } \\
\text { FACIL } \\
\text { COSTS }\end{array}$ & $\begin{array}{l}\text { STOR } \\
\text { AREA } \\
\text { COSTS }\end{array}$ & $\begin{array}{l}\text { MODULE } \\
\text { COSTB }\end{array}$ & $\begin{array}{r}\text { OPERAT } \\
\text { COSTS }\end{array}$ & $\begin{array}{l}\text { F IS } \\
\text { DEVEL } \\
\text { COSTS }\end{array}$ & $\begin{array}{l}\text { GOVT } \\
\text { ADMIN } \\
\text { COSTS }\end{array}$ & $\begin{array}{l}\text { TOTAL } \\
\text { COSTS }\end{array}$ & $\begin{array}{l}\text { DISC. } \\
\text { TOTAL } \\
\text { COSTS }\end{array}$ \\
\hline $\begin{array}{l}1989 \\
1990 \\
1991 \\
1992 \\
1993 \\
1994 \\
1995 \\
1996 \\
1997 \\
1998 \\
1999 \\
2000 \\
2001 \\
2002 \\
2003 \\
2004 \\
2005 \\
2006\end{array}$ & $\begin{array}{r}1499 \\
114 \\
3723 \\
3666\end{array}$ & $\begin{array}{r}2289 \\
155 \\
3603 \\
3525\end{array}$ & $\begin{array}{l}15450 \\
30900 \\
30900 \\
30900 \\
15450\end{array}$ & $\begin{array}{c}3132 \\
6263 \\
6263 \\
6263 \\
4093 \\
1922 \\
1922 \\
1922 \\
1922 \\
1922 \\
1922 \\
7630 \\
7630 \\
7630 \\
284354\end{array}$ & $\begin{array}{r}630 \\
1260 \\
1260 \\
630\end{array}$ & $\begin{array}{l}900 \\
900 \\
900 \\
900 \\
900 \\
900 \\
900 \\
900 \\
900 \\
900 \\
900 \\
900 \\
900 \\
900 \\
900 \\
900 \\
900 \\
900\end{array}$ & $\begin{array}{r}5317 \\
2429 \\
9486 \\
27303 \\
38063 \\
30063 \\
38063 \\
20443 \\
2822 \\
2822 \\
2822 \\
2822 \\
2822 \\
2822 \\
8530 \\
8530 \\
8530 \\
29335\end{array}$ & $\begin{array}{r}5317 \\
2381 \\
9118 \\
25728 \\
35164 \\
34475 \\
33799 \\
17797 \\
2409 \\
2361 \\
2315 \\
2270 \\
2225 \\
2101 \\
6465 \\
6338 \\
6214 \\
20950\end{array}$ \\
\hline TOTAL & 9002 & 9571 & 123600 & 88871 & 3780 & 16200 & 251024 & 217507 \\
\hline
\end{tabular}

- Decommissioning COST

INITIAL PAYMENT = $76 \% / \mathrm{KgU}$ (INCLUDES $\$ / \mathrm{KgU}$ IMPACT AID)

FINAL PAYMENT = 55 \$KLU (INCLUDES * 8/KOU IMPACT AID)

TABLE A10-34

COST SENSITIVITY CASE - - 5-YEAR RECE IPT OF SPENT FUEL

EST IMATED SPENDING SCHEDULE FOR STORAGE DF 4479 DRYWELLS ( $1900 \mathrm{MTU})$

AT GOVERNMENT SITE WITH EXISTING FACILITIES

$(\$ 000,1989)$

\begin{tabular}{|c|c|c|c|c|c|c|c|c|}
\hline YEAR & $\begin{array}{l}\text { JRANS } \\
\text { FACIL } \\
\text { COSTS }\end{array}$ & $\begin{array}{l}\text { STDR } \\
\text { AREA } \\
\text { COSTS }\end{array}$ & $\begin{array}{r}\text { MODULE } \\
\text { COSTE }\end{array}$ & $\begin{array}{r}\text { OPERAT } \\
\text { COSTS }\end{array}$ & $\begin{array}{l}\text { F I } 8 \\
\text { DEVEL } \\
\text { COSTS }\end{array}$ & $\begin{array}{l}\text { QOVT. } \\
\text { ADMIN } \\
\text { COSTS }\end{array}$ & $\begin{array}{l}\text { TOTAL } \\
\text { COSTS }\end{array}$ & $\begin{array}{l}\text { DISC, } \\
\text { TOTAL } \\
\text { COSTS }\end{array}$ \\
\hline $\begin{array}{l}1989 \\
1990 \\
1991\end{array}$ & $\begin{array}{r}1497 \\
114 \\
3723\end{array}$ & $\begin{array}{r}228 \mathrm{BB} \\
155 \\
3603\end{array}$ & & & $\begin{array}{r}630 \\
1260 \\
1260\end{array}$ & $\begin{array}{l}900 \\
900 \\
900\end{array}$ & $\begin{array}{l}5317 \\
2429 \\
9496\end{array}$ & $\begin{array}{l}3317 \\
2381 \\
9118\end{array}$ \\
\hline $\begin{array}{l}1991 \\
1992 \\
1993\end{array}$ & 3666 & 3525 & $\begin{array}{l}12360 \\
24720\end{array}$ & $\begin{array}{l}2722 \\
5443\end{array}$ & $\begin{array}{r}1260 \\
630\end{array}$ & $\begin{array}{l}900 \\
900 \\
900\end{array}$ & $\begin{array}{r}9486 \\
23803 \\
31063\end{array}$ & $\begin{array}{r}9118 \\
22430 \\
28697\end{array}$ \\
\hline $\begin{array}{l}1994 \\
1995\end{array}$ & & & $\begin{array}{l}24720 \\
24720\end{array}$ & $\begin{array}{l}3443 \\
5443\end{array}$ & & 900 & $\begin{array}{l}31063 \\
31063\end{array}$ & $\begin{array}{l}28135 \\
27583\end{array}$ \\
\hline 1996 & & & 24720 & 5443 & & 900 & 31063 & $\begin{array}{l}27583 \\
27042\end{array}$ \\
\hline 1997 & & & 12360 & 3683 & & 900 & 16943 & 14461 \\
\hline 1998 & & & & 1922 & & 900 & 2822 & 2361 \\
\hline 1999 & & & & 1922 & & 900 & 2822 & 2315 \\
\hline 2000 & & & & 1922 & & 900 & 2822 & 2270 \\
\hline 2001 & & & & 1922 & & 900 & 2922 & 2225 \\
\hline 2002 & & & & 1922 & & 900 & 2822 & 2181 \\
\hline 2003 & & & & 7630 & & 900 & 8530 & 6465 \\
\hline 2004 & & & & 7630 & & 900 & B530 & 6338 \\
\hline 2005 & & & & 7630 & & 900 & 8530 & 6214 \\
\hline 2006 & & & & 28435 & & 900 & 29335 & 20950 \\
\hline TOTAL & 9002 & 9571 & 123600 & 89112 & 3780 & 16200 & 251265 & 216983 \\
\hline
\end{tabular}

- DECOMmISSIONING COST

INITIAL PAYMENT = 75 \$ $/ \mathrm{KgU}$ (INCLUDES * 4/KGU IMPACT AID)

FINAL PAYMENT - 56 $\mathrm{KgU}$ (INCLUDES $* 6 / \mathrm{KgU}$ IMPACT AID) 
The impact on FIS costs of compressing the construction schedule for FIS facilities to a total of two years, compared with the base case of four years (implies no NRC licensing activities required), is shown in Table A10-35.

TABLE A10-35

IMPACT OF SHORTENING OF CONSTRUCTION TIME FOR FIS FACILITIES

ON FIS SYSTEM COSTS

FIS Facility

Construction

Time (yr)

New Transfer Facility Cases

$4 \mathrm{yr}$. (Base Case)

$2 \mathrm{yr}$.

Increase per yr. of schedule shortening

Existing Transfer Facility Cases

$4 \mathrm{yr}$. (Base Case)

$2 \mathrm{yr}$.

Increase per yr. of schedule

shortening
$100 \mathrm{MTU}$

\begin{tabular}{cc}
\hline Total & Tatal \\
Discounted & Unit \\
Cost $(\$ 000)$ & Cost $(\$ / \mathrm{kgU}$ \\
\hline
\end{tabular}

$\$ 68,659$

73,584

2,462

$\$ 48,775$

51,849

1,537

The estimated spending schedules, discounted annual costs, and the caiculation of the Initial and Final Payments for FIS of spent fuel for each of the cases considered in Table A10-35 are set forth in Tables A10-36 through A10-39. 
TABLE A10.36

COST SENSITIVITY CASE - 2-YEAR CONSTRUCTION SCHEDULE

ESTIMATED SPENDING SCHEDURE FOR STORAGE OF 236 DRYWELLS ( 100 MTU) AT GOVERNMENT SITE WITHOUT EXISTING FACILITIES

(\$000, 1989)

\begin{tabular}{|c|c|c|c|c|c|c|c|c|}
\hline YEAR & $\begin{array}{l}\text { TRANS } \\
\text { FACIL } \\
\text { COSIS }\end{array}$ & $\begin{array}{l}\text { STOR } \\
\text { AREA } \\
\text { CDSTS }\end{array}$ & $\begin{array}{l}\text { MODLLE } \\
\text { COSTS }\end{array}$ & $\begin{array}{r}\text { OPERAT } \\
\text { CQSTS }\end{array}$ & $\begin{array}{l}\text { FIS } \\
\text { DEVEL } \\
\text { COSTS }\end{array}$ & $\begin{array}{l}\text { GOVT } \\
\text { ADMIN } \\
\text { COSTS }\end{array}$ & $\begin{array}{l}\text { TOTAL } \\
\text { COSTS }\end{array}$ & $\begin{array}{l}\text { DISC. } \\
\text { TOTAL } \\
\text { COSTS }\end{array}$ \\
\hline $\begin{array}{l}1989 \\
1990 \\
1991 \\
1992 \\
1993 \\
1994 \\
1995 \\
1996 \\
1997 \\
1998 \\
1999\end{array}$ & $\begin{array}{r}13290 \\
9270\end{array}$ & $\begin{array}{l}3947 \\
1911\end{array}$ & $\begin{array}{l}1086 \\
2171 \\
2171 \\
1086\end{array}$ & $\begin{array}{l}1107 \\
2214 \\
2214 \\
2091 \\
1967 \\
1967 \\
1967 \\
1967 \\
1967 \\
1967\end{array}$ & $\begin{array}{r}630 \\
1260 \\
1260 \\
630\end{array}$ & $\begin{array}{l}230 \\
230 \\
230 \\
230 \\
230 \\
230 \\
230 \\
230 \\
230 \\
230 \\
230\end{array}$ & $\begin{array}{r}18103 \\
14864 \\
5975 \\
5245 \\
3407 \\
2197 \\
2197 \\
2197 \\
2197 \\
2197 \\
2197\end{array}$ & $\begin{array}{r}19105 \\
14573 \\
3647 \\
4942 \\
3149 \\
1990 \\
1951 \\
1913 \\
1975 \\
1839 \\
1802\end{array}$ \\
\hline $\begin{array}{l}2000 \\
2001\end{array}$ & & & & $\begin{array}{l}1967 \\
1967\end{array}$ & & $\begin{array}{l}230 \\
230\end{array}$ & $\begin{array}{l}2197 \\
2197\end{array}$ & $\begin{array}{l}1767 \\
1732\end{array}$ \\
\hline 2002 & & & & 1967 & & 230 & 2197 & 1699 \\
\hline 2003 & & & & 2214 & & 230 & 2444 & 1852 \\
\hline 2004 & & & & 2214 & & 230 & 2444 & 1816 \\
\hline 2005 & & & & 2214 & & 230 & 2444 & 1780 \\
\hline 2006 & & & & 6988 & & 230 & 7218 & 5155 \\
\hline TOTAL & 22568 & $58 \overline{58}$ & 6514 & 38959 & 3780 & 4140 & 81819 & 73584 \\
\hline
\end{tabular}

* - Decommissioning COST

INITIAL PAYMENT = $371 * / K g U$ (INCLUDES $3 / K g U$ IMPACT AID)

FINAL PAYMENT = 398 KGU (INCLUDES $10 / \mathrm{KgU}$ IMPACT AID)

TABLE A10-37

COST SENSITIVITY CASE - - 2-YEAR CONSTRUCTION SCHEDULE ESTIMATED SFENDING SCHEDULE FOR STORAGE OF 4479 DRYWELLS ( $1900 \mathrm{MTU})$ AT GOVERNMENT SITE WITHOUT EXISTING FACILITIES

$(1000,1989)$

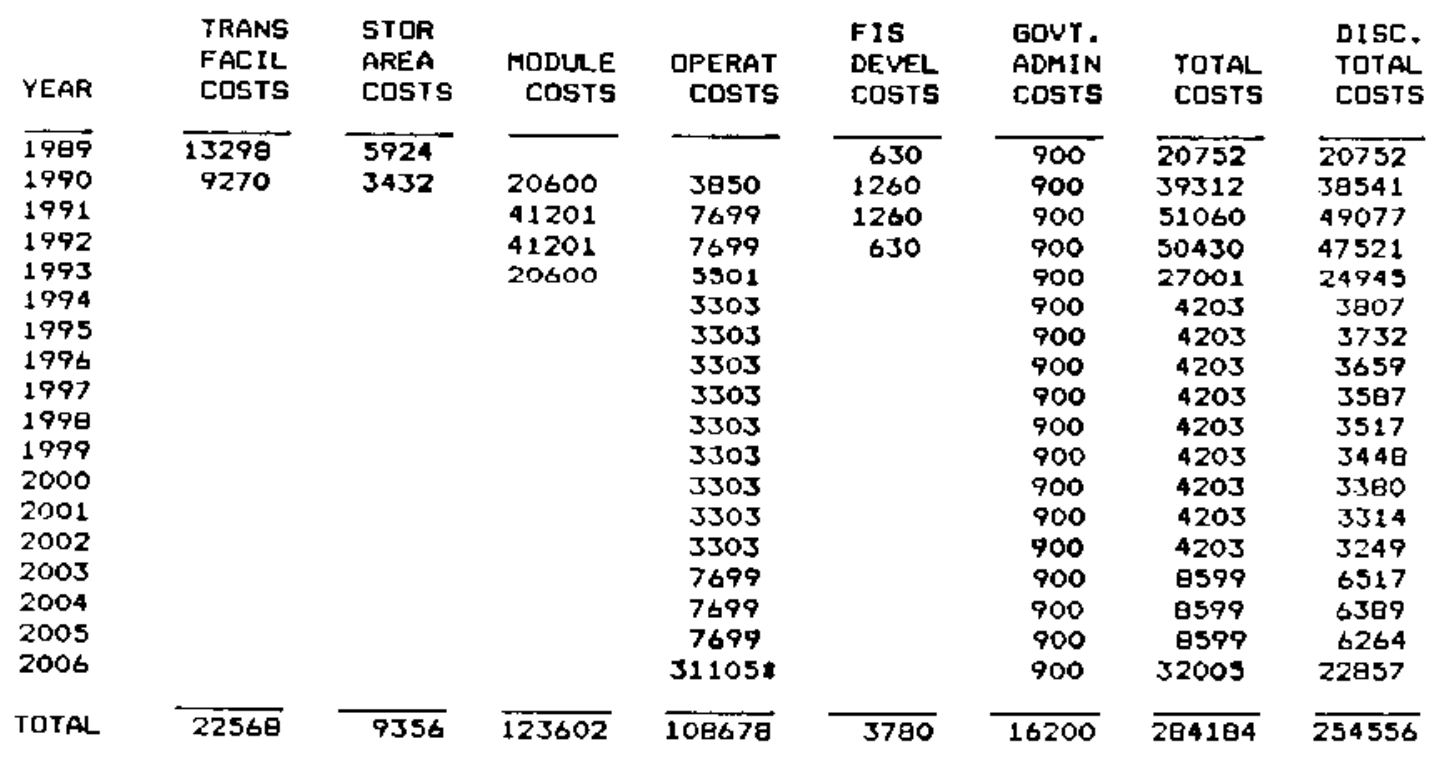

- decommissioning cost

INITIAL PAYMENT = BS $\$ / K g U$ (INCLUDES $5 / K g U$ IMPACT AID)

FINAL PAYMENT = 65 KGU (INCLUDES $9 / \mathrm{KgU}$ IHPACT AID) 
TABLE AIO-38

COST SENSIIIVITY CASE - - 2-YEAR CONSTRUCTION SCHEDULE

ESTIMATED SPENDING SCHEDULE FOR STDRAGE OF 236 DRYWELLS ( 100 HTU) AT GOVERNMENT SITE WITH EXISTING FACILITIES

$(\$ 000,1989)$

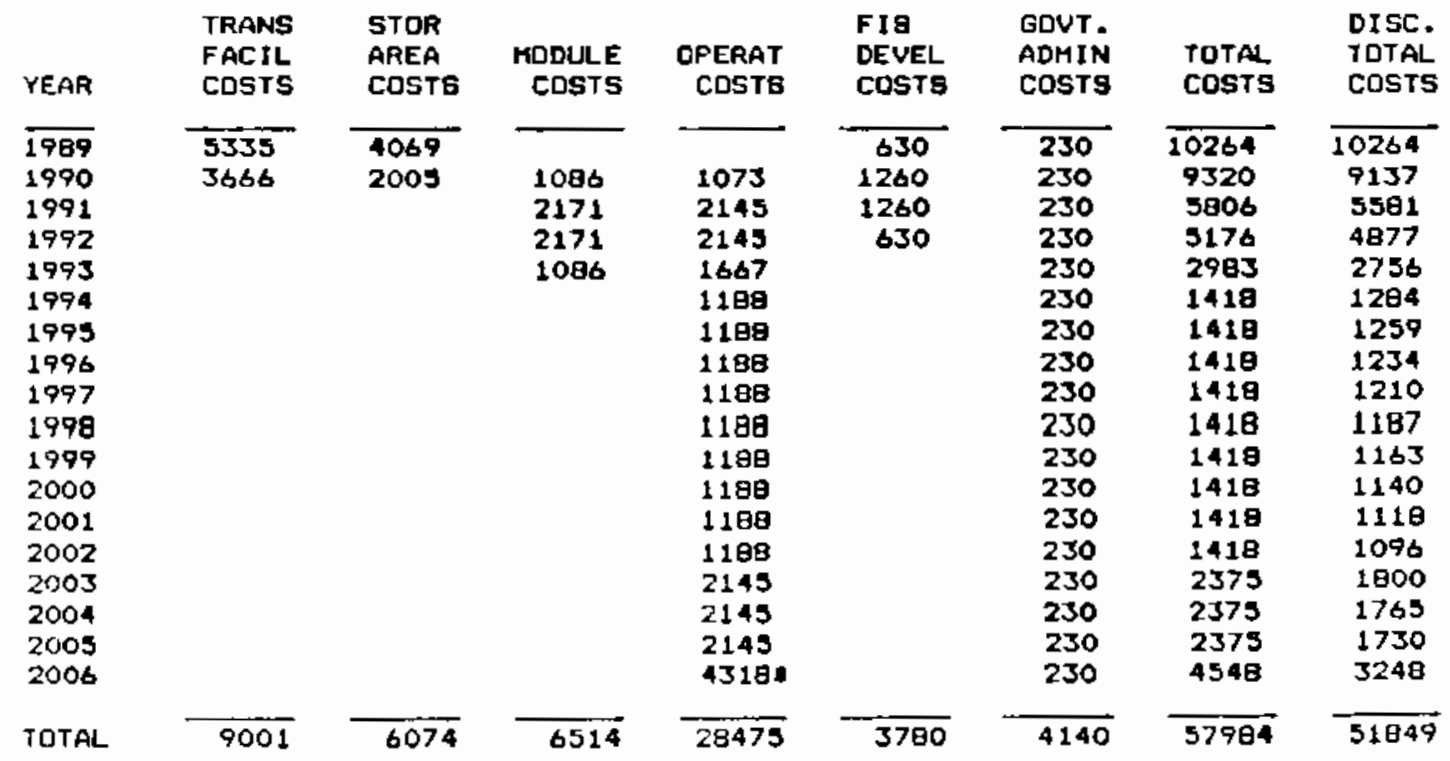

* - decommissioning cost

INITIAL PAYMENT = $237 / \mathrm{KQU}$ (INCLUDES $5 / \mathrm{KgU}$ IMPACT AID)

FINAL PAYMENT * 311 KgU (INCLUDES * 10/KgU IMPACT AID)

TABLE $A 10.39$

COST SENSITIVITY CASE - 2-YEAR CONSTRUCTION SCHEDULE

ESTIMATED SFENOING SCHEDULE FOF STORAGE OF 4478 DRYWELLS (1900 MTU) AT GOVERNMENT SITE WITH EXISTING FACILITIES

$(\$ 000,1989)$

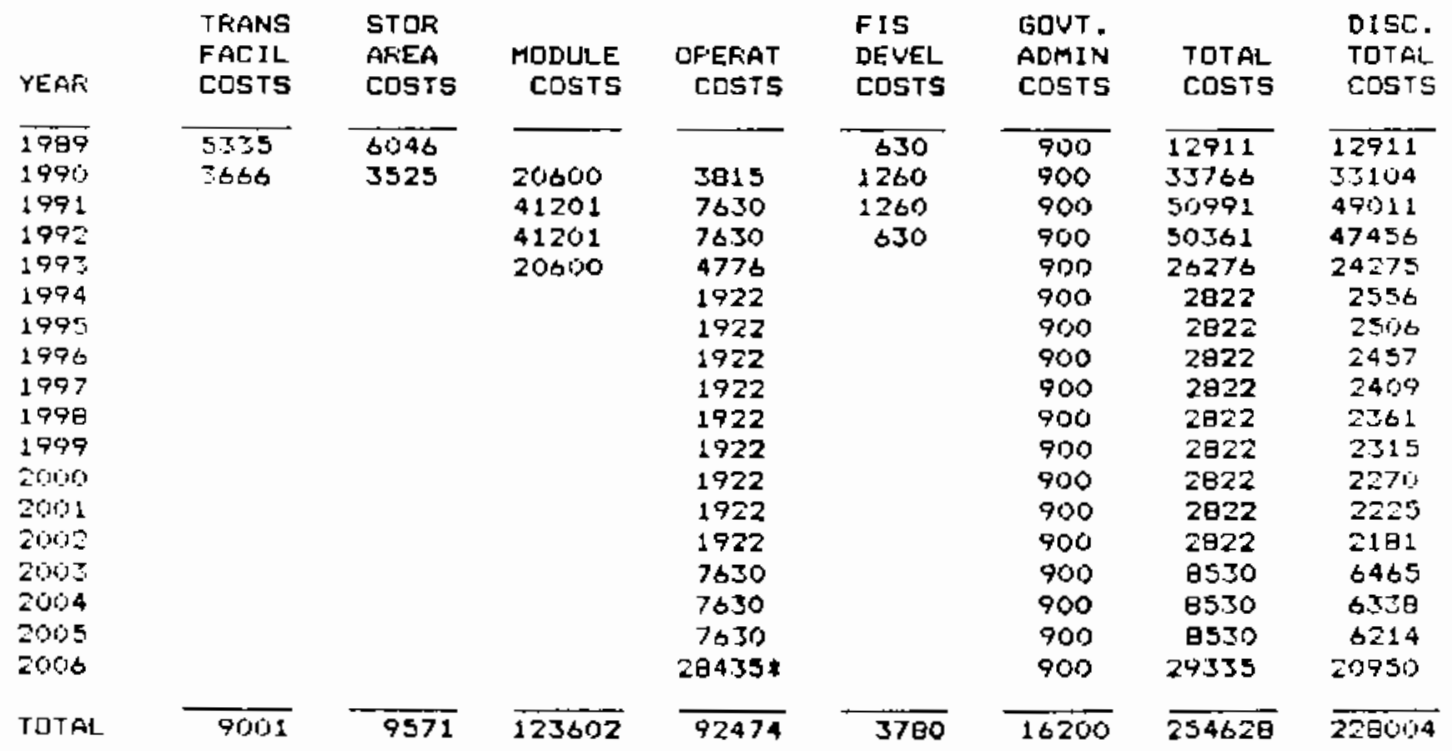

* - decommissioning cost

INITIAL FAYMENT a 77 \$ KGU (INCLUDES * 4/KgU IMFACT AID)

FINAL FAYMENT a 57 K KU (INCLUDES $\$$ G/KgU IMPACT AID) 
10.3 IMPACT OF MIX OF SPENT FUEL TYPES

In developing the costs for FIS storage described in Section 9.0 of this Exhibit $A$, it was assumed that a mix of spent fuel would be received such that an average loading of a drywell would be 0.429 MTU (two-thirds of the fuel received would be PWR fuel containing 0.461 MTU/assembly, and one third of the fuel received would be BWR fuel containing 0.183 MTU/assembly -- with one PWR or two BWR assemblies being contained in a single drywell). The impact of receiving 100\% PWR and 100\% BWR fuel on FIS costs is shown in Table A10-40.

TABLE A10-40

IHPACT OF AMOUNT OF URANIUM CONTAINED IN A DRYWELL ON FIS SYSTEM COSTS

\begin{tabular}{|c|c|c|c|c|}
\hline & \multicolumn{2}{|c|}{100 MTU } & \multicolumn{2}{|c|}{1900 MTU } \\
\hline & $\begin{array}{c}\text { Total } \\
\text { Discounted } \\
\text { Cost }(\$ 000) \\
\end{array}$ & $\begin{array}{c}\text { Total } \\
\text { Unit } \\
\text { Cost }(\$ / \mathrm{kgU}) \\
\end{array}$ & $\begin{array}{c}\text { Total } \\
\text { Discounted } \\
\text { Cost }(\$ 000)\end{array}$ & $\begin{array}{c}\text { Total } \\
\text { Unit } \\
\text { Cost }(\$ / \mathrm{kgU}) \\
\end{array}$ \\
\hline \multicolumn{5}{|l|}{ New Transfer Facility Cases } \\
\hline 67\% PWR Fuel (Base Case) & $\$ 68,659$ & $\$ 730$ & $\$ 242,158$ & $\$ 146$ \\
\hline 100\% PWR Fuel & 68,083 & 725 & 231,316 & 139 \\
\hline $100 \%$ BWR Fuel & 69,770 & 742 & 263,819 & 159 \\
\hline $\begin{array}{l}\text { Change per } \mathrm{kg} / \mathrm{U} \text { difference } \\
\text { in average content of } \\
\text { drywell }\end{array}$ & 18 & 0.2 & 342 & 0.2 \\
\hline \multicolumn{5}{|l|}{$\begin{array}{l}\text { Existing Transfer Facility } \\
\text { Cases }\end{array}$} \\
\hline 67\% PWR Fuel (Base Case) & $\$ 4 B, 775$ & $\$ 525$ & $\$ 218,545$ & $\$ 131$ \\
\hline $100 \%$ PWR Fuel & $4 \mathrm{~B}, 200$ & 519 & 207,703 & 126 \\
\hline $100 \%$ BWR Fuel & 49,892 & 536 & 240,202 & 145 \\
\hline $\begin{array}{l}\text { Change per } \mathrm{kg} / \mathrm{U} \text { difference } \\
\text { in average content of } \\
\text { drywell }\end{array}$ & 18 & 0.2 & 342 & 0.2 \\
\hline
\end{tabular}

The estimated spending schedules, discounted annual costs, and the calculation of the Initial and Final Payments for FIS of spent fuel for each of the cases considered in Table A10-40 are set forth in Tables A10-41 through A10-48. 
TABLE A10-41

COST SENSITIVITY CASE -. 100\% PUR FUEL

ESTIMATED SPENDING SCHEDLLE FOR STORAGE OF 217 DRYWELLS ( $100 \mathrm{MTU})$ AT GOVERNMENT SITE WITHOUT EXISTING FACILITIES

$(\$ 000,1989)$

\begin{tabular}{|c|c|c|c|c|c|c|c|c|}
\hline YEAR & $\begin{array}{l}\text { TRANS } \\
\text { FACIL } \\
\text { COSTS }\end{array}$ & $\begin{array}{l}\text { STOR } \\
\text { AREA } \\
\text { COSTS }\end{array}$ & $\begin{array}{r}\text { MODULE } \\
\text { COSTS }\end{array}$ & $\begin{array}{r}\text { DPERAT } \\
\text { COSTS }\end{array}$ & $\begin{array}{l}\text { FIS } \\
\text { DEVEL } \\
\text { COSTS }\end{array}$ & $\begin{array}{l}\text { GOUT. } \\
\text { ADMIN } \\
\text { COSTS }\end{array}$ & $\begin{array}{l}\text { TOTAL } \\
\text { COSTS }\end{array}$ & $\begin{array}{l}\text { DISC. } \\
\text { TOTAL } \\
\text { COSTS }\end{array}$ \\
\hline $\begin{array}{l}1999 \\
1990 \\
1991 \\
1992 \\
1993 \\
1994 \\
1995 \\
1996 \\
1997 \\
1998 \\
1999 \\
2000 \\
2001 \\
2002 \\
2003 \\
2004 \\
2005 \\
2006\end{array}$ & $\begin{array}{r}3654 \\
249 \\
9395 \\
9270\end{array}$ & $\begin{array}{r}1805 \\
155 \\
1992 \\
1914\end{array}$ & $\begin{array}{r}998 \\
1997 \\
1997 \\
998\end{array}$ & $\begin{array}{l}1106 \\
2211 \\
2211 \\
2089 \\
1964 \\
1964 \\
1964 \\
1964 \\
1964 \\
1964 \\
1964 \\
2211 \\
2211 \\
2211 \\
68054\end{array}$ & $\begin{array}{r}630 \\
1260 \\
1260 \\
630\end{array}$ & $\begin{array}{l}230 \\
230 \\
230 \\
230 \\
230 \\
230 \\
230 \\
230 \\
230 \\
230 \\
230 \\
230 \\
230 \\
230 \\
230 \\
230 \\
230 \\
230\end{array}$ & $\begin{array}{r}6319 \\
1894 \\
12877 \\
14148 \\
4438 \\
4438 \\
3316 \\
2194 \\
2194 \\
2194 \\
2194 \\
2194 \\
2194 \\
2194 \\
2441 \\
2441 \\
2441 \\
7115\end{array}$ & $\begin{array}{r}319 \\
1857 \\
12377 \\
13332 \\
4100 \\
4020 \\
2945 \\
1910 \\
1073 \\
1936 \\
1800 \\
1765 \\
1730 \\
1696 \\
1850 \\
1814 \\
1778 \\
5091\end{array}$ \\
\hline TOTAL & 22568 & 5966 & 5990 & $34 \overline{\mathrm{Eg} 2}$ & 3780 & 4140 & 77226 & 60005 \\
\hline
\end{tabular}

- DECOMMISSIONING COST

INITIAL PAYMENT = $378 / K g U$ (INCLUDES * 5/KgU IMPACT AID)

FINAL PAYMENT * 347 kgU (IMCLUdes * 10/KqU IMPACT AID)

TABLE A10-42

COST SENSIYIVITY CASE - 1002 BHR FUEL

ESTIMATED SPENDING SCHEDUIE FOR STORAEE DF 273 DRYHELLS ( 100 NTU) AT GOVERNMENT SITE WITHOUT EXISTING FACILITIES $(2000,1989)$

\begin{tabular}{|c|c|c|c|c|c|c|c|c|}
\hline YEAR & $\begin{array}{l}\text { TRANS } \\
\text { FACIL } \\
\text { COSTS }\end{array}$ & $\begin{array}{l}\text { STOR } \\
\text { AREA } \\
\text { COSTS }\end{array}$ & $\begin{array}{r}\text { MODURE } \\
\text { COSTS }\end{array}$ & $\begin{array}{r}\text { OPERAT } \\
\text { COSTS }\end{array}$ & $\begin{array}{l}\text { FIS } \\
\text { DEVEL } \\
\text { COSTS }\end{array}$ & $\begin{array}{l}\text { GOVT. } \\
\text { ADMIN } \\
\text { COSTS }\end{array}$ & $\begin{array}{l}\text { TOTAL } \\
\text { COSTS }\end{array}$ & $\begin{array}{l}\text { DISC, } \\
\text { TDTAL } \\
\text { COSTS }\end{array}$ \\
\hline $\begin{array}{l}1989 \\
1990\end{array}$ & $\begin{array}{r}3654 \\
249\end{array}$ & $\begin{array}{r}1802 \\
155\end{array}$ & & & $\begin{array}{r}630 \\
1260\end{array}$ & $\begin{array}{l}230 \\
230\end{array}$ & $\begin{array}{l}6316 \\
1994\end{array}$ & $\begin{array}{l}6316 \\
1857\end{array}$ \\
\hline 1991 & 9395 & 1983 & & & 1260 & 230 & $1286 \theta$ & 12360 \\
\hline $\begin{array}{l}1992 \\
1993\end{array}$ & 9270 & 1906 & $\begin{array}{l}1256 \\
2512\end{array}$ & $\begin{array}{l}1109 \\
2218\end{array}$ & 630 & $\begin{array}{l}230 \\
230\end{array}$ & $\begin{array}{r}14401 \\
4960\end{array}$ & $\begin{array}{r}13570 \\
4592\end{array}$ \\
\hline $\begin{array}{l}1994 \\
1995\end{array}$ & & & $\begin{array}{l}2312 \\
1256\end{array}$ & $\begin{array}{l}2218 \\
2095\end{array}$ & & $\begin{array}{l}230 \\
230\end{array}$ & $\begin{array}{l}4960 \\
3581\end{array}$ & $\begin{array}{l}4492 \\
3160\end{array}$ \\
\hline 1996 & & & & 1971 & & 230 & 2201 & 1916 \\
\hline 1997 & & & & 1871 & & 230 & 2201 & 1879 \\
\hline $199 \mathrm{~B}$ & & & & 1971 & & 230 & 2201 & 1842 \\
\hline 1999 & & & & 1971 & & 230 & 2201 & 1806 \\
\hline 2000 & & & & 1971 & & 230 & 2201 & 1770 \\
\hline 2001 & & & & 1971 & & 230 & 2201 & 1735 \\
\hline 2002 & & & & 1971 & & 230 & 2201 & 1701 \\
\hline 2003 & & & & 2218 & & 230 & 2448 & 1855 \\
\hline 2004 & & & & 2218 & & 230 & 2448 & 1817 \\
\hline 2005 & & & & 2218 & & 230 & $244 \theta$ & 1783 \\
\hline 2006 & & & & 7190 & & 230 & 7420 & 5299 \\
\hline TOTAL & 22568 & 5946 & 7536 & 35291 & 3790 & 4140 & 79131 & 69770 \\
\hline
\end{tabular}

* - decommissianing COST

INITIAL PAYMENT = 392 * KgU (INCLUDES * 5/KgU IMPACT AID)

FINAL PAYMENT = 350 KgU (INCLUDES $* 10 / \mathrm{Kgl}$ IMPACT AID) 
JABLE A10-43

COST SENSITIVITY CASE $\cdots 100 \%$ PUR FUEL

ESTIMATED SPENDING SCHEDULE FOR STORAGE OF 4121 DRYWELLS ( 1900 MTU) AT GOVERNMENT SITE WITHDUT EXISTING FACILITIES

$(\$ 000,1909)$

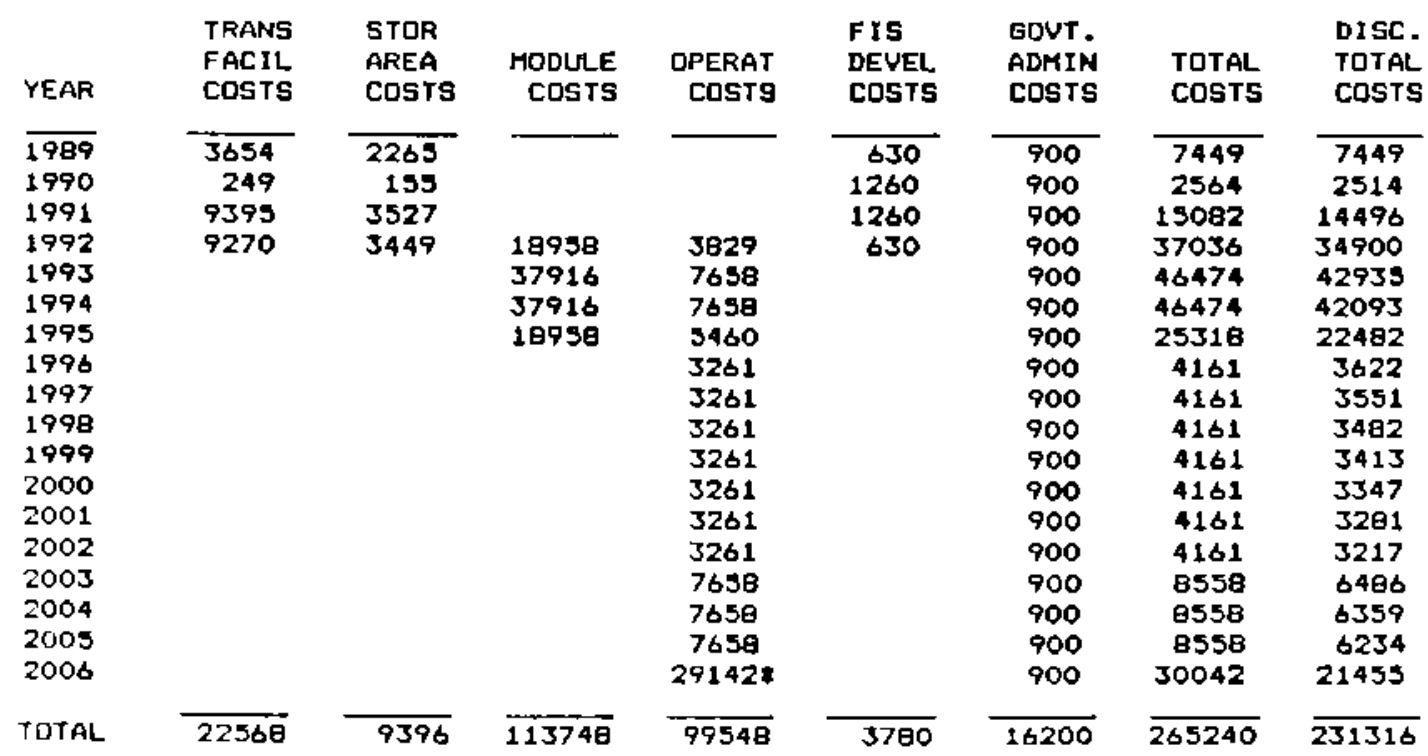

* - Decomaissioning cost

INITIAL PAYMENT = 7B */KQU (INCLUDES 4/KQU IMPACT AID)

FINAL PAYMENT = OI $\mathrm{KOU}$ (INCLUDES $* / \mathrm{KgU}$ IMPACT AID)

IABLE A10-44

COST SENSITIVITY CASE -- 100\% BWR FUEL

ESTIMATED SPENDING SCHEOULE FOR STORAGE OF 5191 DRYWELLS ( 1900 MTU) AT GOVERNRENT SITE WITHOUT EXISTING FACILITIES

$(1000,1989)$

\begin{tabular}{|c|c|c|c|c|c|c|c|c|}
\hline YEAR & $\begin{array}{l}\text { IRANS } \\
\text { FACIL } \\
\text { COSTS }\end{array}$ & $\begin{array}{l}\text { STOR } \\
\text { AREA } \\
\text { COSTS }\end{array}$ & $\begin{array}{l}\text { MDDULE } \\
\text { COSTS }\end{array}$ & $\begin{array}{r}\text { OPERAT } \\
\text { COSTS }\end{array}$ & $\begin{array}{l}\text { FIS } \\
\text { DEVEL } \\
\text { COSTS }\end{array}$ & $\begin{array}{l}\text { GOVT. } \\
\text { ADMIN } \\
\text { COSTS }\end{array}$ & $\begin{array}{l}\text { TOTAL } \\
\text { COSTS }\end{array}$ & $\begin{array}{l}\text { DISC. } \\
\text { TOTAL } \\
\text { COSTS }\end{array}$ \\
\hline 1989 & 3654 & 2249 & & & 630 & 900 & 7433 & 7433 \\
\hline 1990 & 249 & 159 & & & 1260 & 900 & 2564 & 2514 \\
\hline 1991 & 9395 & 3472 & & & 1260 & 900 & 15027 & 14443 \\
\hline 1992 & 9270 & 3395 & 23890 & 3992 & 630 & 900 & 41967 & $3954 b$ \\
\hline $\begin{array}{l}1993 \\
1994\end{array}$ & & & 47761 & 7783 & & 900 & 56444 & $\begin{array}{l}52146 \\
51123\end{array}$ \\
\hline 1995 & & & 23800 & 5585 & & 900 & 30365 & 26963 \\
\hline 1996 & & & & 3387 & & 900 & 4287 & 3732 \\
\hline 1997 & & & & 3387 & & 900 & 4287 & 3659 \\
\hline 1998 & & & & 3387 & & 900 & 4287 & 3587 \\
\hline 1999 & & & & 3387 & & 900 & 4287 & 3517 \\
\hline 2000 & & & & उउB7 & & 900 & $42 \theta 7$ & 3449 \\
\hline 2001 & & & & 3387 & & 900 & 4287 & 3380 \\
\hline 2002 & & & & 3307 & & 900 & 4287 & 3514 \\
\hline 2003 & & & & 7783 & & 900 & 8693 & 6581 \\
\hline 2004 & & & & 7703 & & 900 & B693 & 6452 \\
\hline 2005 & & & & 7783 & & 900 & B6BJ & 6325 \\
\hline 2006 & & & & $35024 \%$ & & 900 & 35924 & 25656 \\
\hline TDTAL & 22568 & 9271 & $\overline{143282}$ & $\overline{107125}$ & 3780 & 16200 & $\overline{302226}$ & $\overline{263819}$ \\
\hline
\end{tabular}

* Decommissianing cost

INITIAL PAYMENT $=94 \% / \mathrm{KgU}$ (INCLUDES $\$ / \mathrm{K} U$ IMPACT AID)

FINAL PAYMENT = $65 \$ K G U$ (INCLUDES $\$ 10 / \mathrm{KgU}$ IMPACT AID) 
TABLE A10-45

COST SENSITIVITY CASE - $100 \%$ PHR FUEL

ESTIMATED SPENDING SCHEDULE FOR STORAGE OF 217 DRYWELLS ( 100 MTU) AT GDVERNMENT SITE WITH EXISTING FACILITIES

$(\$ 000,1989)$

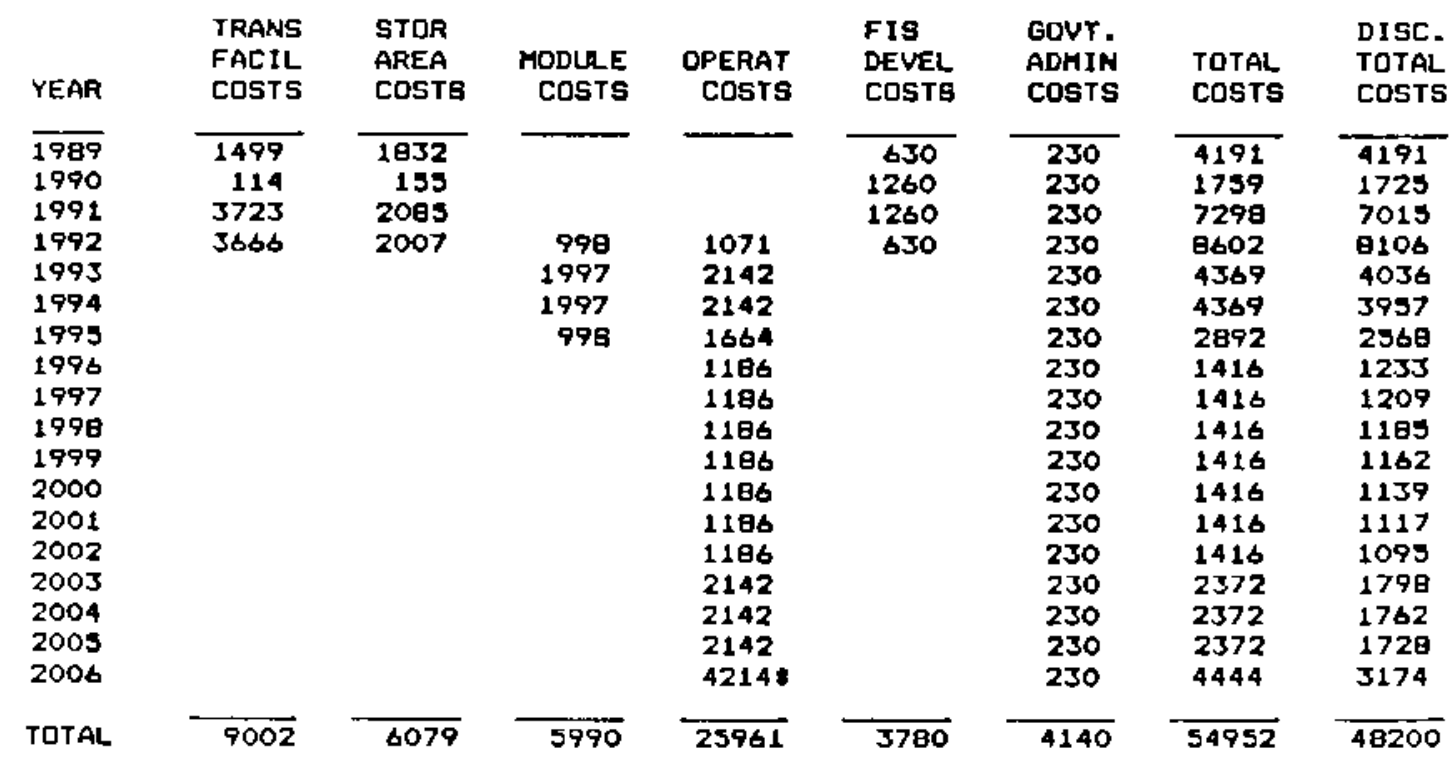

- Decommissioning COST

INITIAL PAYMENT $=249 * \mathrm{KgU}$ (INCLUDES $3 / \mathrm{KgU}$ IMPACT AID)

FINAL PAYMENT $\Rightarrow 271$ KOU (INCLUDES $10 / \mathrm{KgU}$ IMPACT AID)

TABLE A10.46

COST SENSITIUITY CASE - 1002 BHR FUEL

ESTIMATED SPENDING SCHEDULE FDR STORAGE OF 273 DRYWELLS ( 100 MTU) AT GOVERNAENT SITE WITH EXISTING FACILITIES

(\$000, 1989)

\begin{tabular}{|c|c|c|c|c|c|c|c|c|}
\hline YEAR & $\begin{array}{l}\text { TRANS } \\
\text { FACIL } \\
\text { CDSTS }\end{array}$ & $\begin{array}{l}\text { STOR } \\
\text { AREA } \\
\text { COSTS }\end{array}$ & $\begin{array}{r}\text { MODULE } \\
\text { COSTS }\end{array}$ & $\begin{array}{r}\text { OPERAT } \\
\text { COSTS }\end{array}$ & $\begin{array}{l}\text { FIS } \\
\text { DEVEL } \\
\text { COSTS }\end{array}$ & $\begin{array}{l}\text { GOVT. } \\
\text { ADMIN } \\
\text { COSTS }\end{array}$ & $\begin{array}{l}\text { TDTAL } \\
\text { COSTS }\end{array}$ & $\begin{array}{l}\text { DISC. } \\
\text { TOTAL } \\
\text { COSTS }\end{array}$ \\
\hline$\overline{1989}$ & 1499 & 1830 & & & 630 & 230 & 4189 & 4189 \\
\hline 1990 & 114 & 155 & & & 1260 & 230 & 1759 & 1725 \\
\hline 1991 & 3723 & 2077 & & & 1260 & 230 & 7290 & 7007 \\
\hline 1992 & Zobb & 1999 & 1256 & 1075 & 630 & 230 & 8856 & 9345 \\
\hline 1993 & & & 2512 & 2149 & & 230 & 4891 & $45 \pm 9$ \\
\hline 1994 & & & 2512 & 2149 & & 230 & 4891 & 4430 \\
\hline 1995 & & & 1256 & 1671 & & 230 & 3157 & 2003 \\
\hline 1996 & & & & 1193 & & 230 & 1423 & 1239 \\
\hline 1997 & & & & 1193 & & 230 & 1423 & 1215 \\
\hline 1998 & & & & 1193 & & 230 & 1423 & 1191 \\
\hline 1999 & & & & 1193 & & 230 & 1423 & 1167 \\
\hline 2000 & & & & 1193 & & 230 & 1423 & 1144 \\
\hline 2001 & & & & 1193 & & 230 & 1423 & 1122 \\
\hline 2002 & & & & 1293 & & 250 & 1423 & 1100 \\
\hline 2003 & & & & 2149 & & 230 & 2379 & 1803 \\
\hline 2004 & & & & 2149 & & 230 & 2379 & 1760 \\
\hline 2005 & & & & 2149 & & 230 & 2379 & 1733 \\
\hline 2006 & & & & $4520 t$ & & 230 & 4750 & 3392 \\
\hline TOTAL & 9002 & 6061 & 7536 & 26362 & 3780 & 4540 & 56891 & 49092 \\
\hline
\end{tabular}

* - decommissioning cost

Initial PAyment * $262 * / \mathrm{KgU}$ (INCludes * 5/KgU Impaet AID)

FINAL PAYMENT = 274 KKGU (INCLUDES $10 / \mathrm{KgU}$ IMFACT AID) 
TABLE A10-47

COST SENSITIVITY CASE $-2100 \%$ PHR FUEL

EST IMATED SPENDING SCHEDLLE FOR STORAGE OF 4121 DRYWELLS ( 1900 MTU) AT GOVERNMENT SITE WITH EXISTING FACILITIES

$(\$ 000,1989)$

\begin{tabular}{|c|c|c|c|c|c|c|c|c|}
\hline YEAR & $\begin{array}{l}\text { TRANS } \\
\text { FACIL } \\
\text { COSTS }\end{array}$ & $\begin{array}{l}\text { STOR } \\
\text { AREA } \\
\text { COSTS }\end{array}$ & $\begin{array}{l}\text { MODURE } \\
\text { COSTS }\end{array}$ & $\begin{array}{r}\text { OPERAT } \\
\text { COSTE }\end{array}$ & $\begin{array}{l}\text { FIS } \\
\text { DEVEL } \\
\text { COSTS }\end{array}$ & $\begin{array}{l}\text { GOVT. } \\
\text { ADMIN } \\
\text { COETS }\end{array}$ & $\begin{array}{l}\text { TOTAL } \\
\text { COSTS }\end{array}$ & $\begin{array}{l}\text { DISC. } \\
\text { TOTAL } \\
\text { COSTS }\end{array}$ \\
\hline $\begin{array}{l}1989 \\
1990 \\
1991 \\
1992 \\
1993 \\
1994 \\
1995 \\
1996 \\
1997\end{array}$ & $\begin{array}{r}1499 \\
114 \\
3723 \\
3666\end{array}$ & $\begin{array}{r}2293 \\
155 \\
3621 \\
3543\end{array}$ & $\begin{array}{l}18938 \\
37916 \\
37916 \\
18958\end{array}$ & $\begin{array}{l}3795 \\
7589 \\
7589 \\
4735 \\
1890 \\
1880\end{array}$ & $\begin{array}{r}630 \\
1260 \\
1260 \\
630\end{array}$ & $\begin{array}{l}900 \\
900 \\
900 \\
900 \\
900 \\
900 \\
900 \\
900 \\
900\end{array}$ & $\begin{array}{r}5322 \\
2429 \\
9504 \\
31492 \\
46405 \\
46405 \\
24593 \\
2790 \\
2700\end{array}$ & $\begin{array}{r}5322 \\
2381 \\
9135 \\
29676 \\
42971 \\
42030 \\
21630 \\
2420 \\
2373\end{array}$ \\
\hline $\begin{array}{l}1998 \\
1999\end{array}$ & & & & $\begin{array}{l}1000 \\
1880 \\
1880\end{array}$ & & 900 & $\begin{array}{l}2780 \\
2780\end{array}$ & $\begin{array}{l}2326 \\
2281\end{array}$ \\
\hline 2000 & & & & $18 \theta 0$ & & 900 & 2780 & 2236 \\
\hline 2001 & & & & 1880 & & 900 & 2780 & 2192 \\
\hline 2002 & & & & 1890 & & 900 & 2780 & 2149 \\
\hline 2003 & & & & 7589 & & 900 & 8489 & 6434 \\
\hline 2004 & & & & 7589 & & 900 & 8489 & 6307 \\
\hline 2005 & & & & 7589 & & 900 & 8489 & 6184 \\
\hline 2006 & & & & 264724 & & 900 & 27372 & 19548 \\
\hline TOTAL & 9002 & 9612 & $1 \longdiv { 1 3 7 4 8 }$ & 86107 & 3780 & 16200 & $\overline{238449}$ & 207703 \\
\hline
\end{tabular}

- DECOMMISSIONING COST

INITIAL PAYMENT = 72 /KgU (INCLUDES * 4/KgU IMPACT AID)

FINAL PAYMENT = 34 KgU (INCLUDES $* / K O U$ IMPACT AID)

TABLE A10-48

COST SENSITIVITY CASE - - 100\% BWR FUEL

ESTIMATED SFENDING SCHEDULE FDR STORAGE OF $\$ 191$ DRYWELLS ( $1900 \mathrm{MTU})$ AT GOUERNMENT SITE WITH EXISTINB FACILITIES

$(\$ 000,1989)$

\begin{tabular}{|c|c|c|c|c|c|c|c|c|}
\hline YEAR & $\begin{array}{l}\text { TRANS } \\
\text { FACIL } \\
\text { COSTS }\end{array}$ & $\begin{array}{l}\text { STOR } \\
\text { AREA } \\
\text { COSTS }\end{array}$ & $\begin{array}{r}\text { MODULE } \\
\text { COSTS }\end{array}$ & $\begin{array}{r}\text { DPERAY } \\
\text { CDSTS }\end{array}$ & $\begin{array}{l}\text { FIS } \\
\text { DEVEL } \\
\text { COSTS }\end{array}$ & $\begin{array}{l}\text { GOVT. } \\
\text { ADMIN } \\
\text { COSTS }\end{array}$ & $\begin{array}{l}\text { TOTAL } \\
\text { COSTS }\end{array}$ & $\begin{array}{l}\text { DISC, } \\
\text { JOTAL } \\
\text { COSTS }\end{array}$ \\
\hline 1989 & 1497 & 2277 & & & 630 & 900 & 5306 & 5306 \\
\hline $\begin{array}{l}1990 \\
1991\end{array}$ & $\begin{array}{r}114 \\
3723\end{array}$ & $\begin{array}{r}155 \\
3565\end{array}$ & & & $\begin{array}{l}1260 \\
1260\end{array}$ & $\begin{array}{l}900 \\
900\end{array}$ & $\begin{array}{l}2429 \\
9448\end{array}$ & $\begin{array}{l}2381 \\
9081\end{array}$ \\
\hline 1992 & 3666 & 3488 & 23880 & 3857 & 630 & 900 & 36421 & 34320 \\
\hline 1993 & & & 47761 & 7714 & & 900 & 36375 & 52082 \\
\hline 2994 & & & 47761 & 7714 & & 900 & 56375 & 51061 \\
\hline 1995 & & & 23890 & 4860 & & 900 & 29640 & 26319 \\
\hline 1996 & & & & 2004 & & 900 & 2706 & 2530 \\
\hline 1997 & & & & 2006 & & 900 & 2906 & 2480 \\
\hline 1998 & & & & 2006 & & 900 & 2906 & 2432 \\
\hline 1999 & & & & 2006 & & 900 & 2908 & 2384 \\
\hline 2000 & & & & 2006 & & 900 & 2906 & 2337 \\
\hline 2001 & & & & 2006 & & 900 & 2906 & 2291 \\
\hline 2002 & & & & 2006 & & 900 & 2906 & 2246 \\
\hline 2003 & & & & 7714 & & 900 & 8614 & 6528 \\
\hline 2004 & & & & 7714 & & 900 & 8614 & 6400 \\
\hline 2005 & & & & 7714 & & 900 & 8614 & 6275 \\
\hline 2004 & & & & $32354:$ & & 900 & 33254 & 23749 \\
\hline TDTAL & 9002 & 9485 & 143282 & 93683 & 3780 & 16200 & 275432 & 240202 \\
\hline
\end{tabular}

* - DECDMmissioning COST

INITIAL PAYMENT = 07 * KgU (INCLUDES $5 / \mathrm{KgU}$ IMPACT AID)

FINAL PAYMENT $\rightarrow 58 \$ K G U$ (INCLUDES $\$ / K g U$ IMPACT AID) 
10.4 IMPACT OF DISCOUNT RATE

The impact of changes to the discount rate used to calculate fis service charges on FIS costs is shown in Table A10-49.

TABLE A10-49

IMPACT OF DISCOUNT RATE ON FIS SYSTEM COSTS

Discount Rate

New Transfer Facility Cases

2\% (Base Case)

$4 \%$

$6 \%$

Decrease per percent increase in discount rate

Existing Transfer Facility Cases

2\% (Base Case)

$4 \%$

$6 \%$

Decrease per percent

increase in discount rate
100 MTU

$\begin{array}{cc}\text { Total Total } \\ \text { Oiscounted } & \text { Unit }\end{array}$

$\frac{1900 \text { MTU }}{\begin{array}{c}\text { Total } \\ \text { Discounted }\end{array}} \begin{gathered}\text { Total } \\ \text { Unit }\end{gathered}$

Cost $(\$ 000)$ Cost $(\$ / \mathrm{kgU})$ 
TABLE A10-50

COST SENSITIVITY CASE . 4 I DISCOUNT RATE

ESTIMATED SPENDING SCHEDULE FDR STORAGE OF 236 DRYWELLS ( 100 MTU) AT GOVERNMENT SITE WITHOUT EXISTING FACILITIES

$(\$ 000,1989)$

\begin{tabular}{|c|c|c|c|c|c|c|c|c|}
\hline YEAR & $\begin{array}{l}\text { TRANS } \\
\text { FACIL } \\
\text { COSTS }\end{array}$ & $\begin{array}{l}\text { STOR } \\
\text { AREA } \\
\text { COSTS }\end{array}$ & $\begin{array}{l}\text { MODULE } \\
\text { COST }\end{array}$ & $\begin{array}{r}\text { OPERAT } \\
\text { COSTS }\end{array}$ & $\begin{array}{l}\text { F IS } \\
\text { DEVEL } \\
\text { COSTS }\end{array}$ & $\begin{array}{l}\text { GOVT, } \\
\text { ADHIN } \\
\text { CDSTS }\end{array}$ & $\begin{array}{l}\text { TOTAL } \\
\text { COSTS }\end{array}$ & $\begin{array}{l}\text { DISC, } \\
\text { TOTAL } \\
\text { COSTS }\end{array}$ \\
\hline $\begin{array}{l}1999 \\
1990 \\
1991 \\
1992 \\
1993 \\
1994 \\
1995 \\
1996 \\
1997 \\
1998 \\
1999 \\
2000 \\
2001 \\
2002 \\
2003 \\
2004 \\
2005 \\
2006\end{array}$ & $\begin{array}{r}3654 \\
249 \\
9395 \\
9270\end{array}$ & $\begin{array}{r}1804 \\
155 \\
1989 \\
1911\end{array}$ & $\begin{array}{l}1086 \\
2171 \\
2171 \\
1086\end{array}$ & $\begin{array}{l}1107 \\
2214 \\
2214 \\
2091 \\
1967 \\
1967 \\
1967 \\
1967 \\
1967 \\
1967 \\
1967 \\
2214 \\
2214 \\
2214 \\
6988\end{array}$ & $\begin{array}{r}630 \\
1260 \\
1260 \\
630\end{array}$ & $\begin{array}{l}230 \\
230 \\
230 \\
230 \\
230 \\
230 \\
230 \\
230 \\
230 \\
230 \\
230 \\
230 \\
230 \\
230 \\
230 \\
230 \\
230 \\
230\end{array}$ & $\begin{array}{r}6310 \\
1994 \\
12974 \\
14234 \\
4615 \\
4615 \\
3407 \\
2197 \\
2197 \\
2197 \\
2197 \\
2197 \\
2197 \\
2197 \\
2444 \\
2444 \\
2444 \\
7218\end{array}$ & $\begin{array}{r}6318 \\
1821 \\
11903 \\
12694 \\
3945 \\
3793 \\
2693 \\
1670 \\
1605 \\
1544 \\
1484 \\
1427 \\
1372 \\
1319 \\
1411 \\
1357 \\
1305 \\
3706\end{array}$ \\
\hline TOTAL & $\overline{225 \triangle 8}$ & 5859 & 6514 & 35025 & 3780 & 4140 & $\overline{77806}$ & 61327 \\
\hline
\end{tabular}

- Decommissioning cost

INITIAL PAYMENT = 366 /KgU (INCLUDES * 5/KgU IMPACT AID)

FINAL PAYMENT * $311 \mathrm{kgU}$ (INCLUDES $10 / \mathrm{KgU}$ IMPACT AID)

TABLE A10-51

COST SENSITIVITY CASE -. 6\% DISCOUNT RATE

ESTIMATED SPENDING SCHEDULE FOR STOKASE OF 236 DRYWELLS ( 100 ATU) AT GOVERNMENT SITE WITHOUT EXISTING FACILITIES

$(\$ 000,1999)$

\begin{tabular}{|c|c|c|c|c|c|c|c|c|}
\hline YEAR & $\begin{array}{l}\text { TRANS } \\
\text { FACIL } \\
\text { COSTS }\end{array}$ & $\begin{array}{l}\text { STOR } \\
\text { AREA } \\
\text { COSTS }\end{array}$ & $\begin{array}{l}\text { MODULE } \\
\text { COSTS }\end{array}$ & $\begin{array}{r}\text { OPERAT } \\
\text { COSTS }\end{array}$ & $\begin{array}{l}\text { FIS } \\
\text { DEVEL } \\
\text { COSTS }\end{array}$ & $\begin{array}{l}\text { GOVT } \\
\text { ADMIN } \\
\text { COSTS }\end{array}$ & $\begin{array}{l}\text { TOTAL } \\
\text { COSTS }\end{array}$ & $\begin{array}{l}\text { DISC. } \\
\text { TOTAL } \\
\text { COSTS }\end{array}$ \\
\hline $\begin{array}{l}1989 \\
1990\end{array}$ & $\begin{array}{r}3654 \\
249\end{array}$ & $\begin{array}{r}1604 \\
155\end{array}$ & & & $\begin{array}{r}630 \\
1260\end{array}$ & $\begin{array}{l}230 \\
230\end{array}$ & $\begin{array}{l}6316 \\
1994\end{array}$ & $\begin{array}{l}6310 \\
1707\end{array}$ \\
\hline 1991 & 9395 & 1989 & & & 1260 & 230 & 12874 & 11450 \\
\hline 1992 & 9270 & 1911 & 1096 & 1107 & 630 & 230 & 14234 & 12951 \\
\hline 1993 & & & 2171 & 2214 & & 230 & 4615 & 3656 \\
\hline 1994 & & & 2171 & 2214 & & 230 & 4615 & 3449 \\
\hline 1995 & & & 1006 & 2091 & & 230 & 3407 & 2402 \\
\hline 1996 & & & & 1967 & & 230 & 2197 & 1461 \\
\hline 1997 & & & & 1967 & & 230 & 2197 & 1378 \\
\hline 1998 & & & & 1967 & & 230 & 2197 & 1300 \\
\hline 1999 & & & & 1967 & & 230 & 2197 & 1227 \\
\hline 2000 & & & & 1967 & & 230 & 2197 & 1157 \\
\hline 2001 & & & & 1967 & & 230 & 2197 & 1092 \\
\hline 2002 & & & & 1967 & & 230 & 2197 & 1030 \\
\hline 2003 & & & & 2214 & & 230 & 2444 & 1081 \\
\hline 2004 & & & & 2214 & & 230 & 2444 & 1020 \\
\hline 2005 & & & & 2214 & & 230 & 2444 & 962 \\
\hline 2006 & & & & $6980 *$ & & 230 & 7218 & 2681 \\
\hline TOTAL & 22568 & 5959 & 6514 & $\overline{35025}$ & 3780 & 4140 & 77986 & 55410 \\
\hline
\end{tabular}

* - DECOMmissidning COST

INITIAL PAYMENT = $351 * / K Q U$ (INCLUDES $\$$ S/KOU IMPACT AID)

FINAL PAYMENT $m 280 \mathrm{sKgU}$ (INCLUDES *10/KgU IMPACT AID) 
TABLE A10-52

COST SENSITIVITY CASE - - 45 DISCOUNT RATE

EST IMATED SPENDING SCHEDULE FOR STORAGE OF 447̈O DRYWELLS (1900 MTU)

AT GOVERNMENT SITE HITHOUT EXIGTING FACILITIES

$(\$ 000,1969)$

\begin{tabular}{|c|c|c|c|c|c|c|c|c|}
\hline YEAR & $\begin{array}{l}\text { TRANS } \\
\text { FACIL } \\
\text { COSTS }\end{array}$ & $\begin{array}{l}\text { STOR } \\
\text { AREA } \\
\text { COSTS }\end{array}$ & $\begin{array}{r}\text { MODULE } \\
\text { COSTS }\end{array}$ & $\begin{array}{c}\text { OPERAT } \\
\text { COSTS }\end{array}$ & $\begin{array}{l}\text { FIS } \\
\text { DEVEL } \\
\text { COSTS }\end{array}$ & $\begin{array}{l}\text { GOVT } \\
\text { ADMIN } \\
\text { COSTS }\end{array}$ & $\begin{array}{l}\text { TOTAL } \\
\text { COSTS }\end{array}$ & $\begin{array}{l}\text { DISC. } \\
\text { TOTAL. } \\
\text { COSTS }\end{array}$ \\
\hline $\begin{array}{l}1989 \\
1990 \\
1991 \\
1992 \\
1993 \\
1994 \\
1995 \\
1996 \\
1997 \\
1990 \\
1999 \\
2000 \\
2001 \\
2002 \\
2003 \\
2004 \\
2005 \\
2006\end{array}$ & $\begin{array}{r}3654 \\
249 \\
9395 \\
9270\end{array}$ & $\begin{array}{r}2260 \\
135 \\
3309 \\
3432\end{array}$ & $\begin{array}{l}20600 \\
41201 \\
41201 \\
20600\end{array}$ & $\begin{array}{c}3850 \\
7699 \\
7699 \\
5501 \\
3303 \\
3303 \\
3303 \\
3303 \\
3303 \\
3303 \\
3303 \\
7699 \\
7699 \\
7699 \\
31103\end{array}$ & $\begin{array}{r}630 \\
1260 \\
1260 \\
630\end{array}$ & $\begin{array}{l}900 \\
900 \\
900 \\
900 \\
900 \\
900 \\
900 \\
900 \\
900 \\
900 \\
900 \\
900 \\
900 \\
900 \\
900 \\
900 \\
900 \\
900\end{array}$ & $\begin{array}{r}7444 \\
2564 \\
15064 \\
30692 \\
49000 \\
49000 \\
27001 \\
4203 \\
4203 \\
4203 \\
4203 \\
4203 \\
4203 \\
4203 \\
8599 \\
8599 \\
8599 \\
32005\end{array}$ & $\begin{array}{r}7444 \\
2465 \\
13929 \\
34389 \\
42569 \\
40932 \\
21339 \\
3194 \\
3071 \\
2953 \\
2839 \\
2730 \\
2625 \\
2524 \\
4966 \\
4775 \\
4591 \\
16431\end{array}$ \\
\hline TOTAL & 22568 & 9356 & 123602 & $\overline{102072}$ & 3700 & 16200 & 277578 & 213764 \\
\hline
\end{tabular}

* - DECOMmissioning COST

INITIAL PAYMENT $=78 \$ / K g U$ (INCLUDES $\$$ 4/KU IMPACT AID)

FINAL PAYMENT * 55 *KGU (INCLUDEs * $9 / \mathrm{Kg}$ IMPACY AID)

TABLE $A 10-53$

COST SENSITIVITY CASE - $6 \%$ DISCOUNT RATE

ESTIMATED SFENDING SCHEDULE FDR STDRAGE OF 4478 DRYWELLS ( $1900 \mathrm{MTU})$

AT GQVERNMENT SITE WITHOUT EXISTING FACILITIES

$(1000,1989)$

\begin{tabular}{|c|c|c|c|c|c|c|c|c|}
\hline YEAR & $\begin{array}{l}\text { TRANS } \\
\text { FACIL } \\
\text { COSTS }\end{array}$ & $\begin{array}{l}\text { STQR } \\
\text { AREA } \\
\text { COSTS }\end{array}$ & $\begin{array}{r}\text { MODLLE } \\
\text { COSIS }\end{array}$ & $\begin{array}{r}\text { OPERAT } \\
\text { CDSTS }\end{array}$ & $\begin{array}{l}\text { FIS } \\
\text { DEVEL } \\
\text { CDSTS }\end{array}$ & $\begin{array}{l}\text { GOVT. } \\
\text { ADMIN } \\
\text { COSTS }\end{array}$ & $\begin{array}{l}\text { TOTAL } \\
\text { COSTS }\end{array}$ & $\begin{array}{l}\text { DISC. } \\
\text { TOTAL } \\
\text { COSTS }\end{array}$ \\
\hline $\begin{array}{l}1999 \\
1990 \\
1991 \\
1992\end{array}$ & $\begin{array}{r}3654 \\
249 \\
9395 \\
9270\end{array}$ & $\begin{array}{r}2260 \\
155 \\
3509 \\
3432\end{array}$ & & & $\begin{array}{r}630 \\
1260 \\
1260 \\
630\end{array}$ & $\begin{array}{l}900 \\
900 \\
900 \\
900\end{array}$ & $\begin{array}{r}7444 \\
2564 \\
15064 \\
39682\end{array}$ & $\begin{array}{r}7444 \\
2419 \\
13407 \\
32478\end{array}$ \\
\hline $\begin{array}{l}1992 \\
1993 \\
1994\end{array}$ & 9270 & 3432 & $\begin{array}{l}20600 \\
41201 \\
41201\end{array}$ & $\begin{array}{l}3850 \\
7699 \\
7699\end{array}$ & 630 & $\begin{array}{l}900 \\
900 \\
900\end{array}$ & $\begin{array}{l}39682 \\
49000 \\
49800\end{array}$ & $\begin{array}{l}32478 \\
39446 \\
37213\end{array}$ \\
\hline $\begin{array}{l}1995 \\
1996\end{array}$ & & & 20600 & $\begin{array}{l}5501 \\
3303\end{array}$ & & $\begin{array}{l}900 \\
900\end{array}$ & $\begin{array}{r}27001 \\
4203\end{array}$ & $\begin{array}{r}19035 \\
2795\end{array}$ \\
\hline 1997 & & & & 3303 & & 900 & 4203 & 2637 \\
\hline 1998 & & & & 3303 & & 900 & 4203 & 2488 \\
\hline 1999 & & & & 3303 & & 900 & 4203 & 2347 \\
\hline 2000 & & & & 3.303 & & 900 & 4203 & 2214 \\
\hline 2001 & & & & 3303 & & 900 & 4203 & 2089 \\
\hline 2002 & & & & 3303 & & 900 & 4203 & 1971 \\
\hline 2003 & & & & 7699 & & 900 & 8599 & 3803 \\
\hline 2004 & & & & 7699 & & 900 & 8599 & 3580 \\
\hline 2005 & & & & 7699 & & 900 & 8599 & 3365 \\
\hline 2006 & & & & $31105 *$ & & 900 & 32005 & 11806 \\
\hline TOTAL & 22568 & 9356 & $12 \overline{3602}$ & $\overline{102072}$ & 3780 & 16200 & $\overline{277578}$ & 190645 \\
\hline
\end{tabular}

* - Decammissioning COSt

INITIAL PAYMENT * 72 /KgU (INCLUDES * 4/KgU IMPACT AID)

FINAL PAYMENT = 50 KGU (INCLUDES * $9 / \mathrm{KgU}$ IMPACT AID) 
TABLE A10-54

COST SENSITIVITY CASE - $4 \%$ DISCOUNT RATE

ESTIMATED SPENDING SCHEDULE FOR STORAGE OF 236 DRYWELLS ( 100 MTU) AT GOVERNMENT SITE WITH EXISTING FACILITIES

$(\$ 000,1989)$

\begin{tabular}{|c|c|c|c|c|c|c|c|c|}
\hline YEAR & $\begin{array}{l}\text { TRANS } \\
\text { FACIL } \\
\text { COSTS }\end{array}$ & $\begin{array}{l}\text { STOR } \\
\text { AREA } \\
\text { COSTS }\end{array}$ & $\begin{array}{r}\text { MODULE } \\
\text { COST }\end{array}$ & $\begin{array}{r}\text { OPERAT } \\
\text { COSTS }\end{array}$ & $\begin{array}{l}\text { FIS } \\
\text { DEVEL } \\
\text { COSTS }\end{array}$ & $\begin{array}{l}\text { GDVT } \\
\text { ADHIN } \\
\text { COSTS }\end{array}$ & $\begin{array}{l}\text { TOTAL } \\
\text { COSTE }\end{array}$ & $\begin{array}{l}\text { DISC. } \\
\text { TOTAL } \\
\text { COSTS }\end{array}$ \\
\hline $\begin{array}{l}1999 \\
1990 \\
1991 \\
1992 \\
1993 \\
1994 \\
1995 \\
1996 \\
1997 \\
1998 \\
1999 \\
2000 \\
2001 \\
2002 \\
2003 \\
2004 \\
2005 \\
2006\end{array}$ & $\begin{array}{r}1499 \\
114 \\
3723 \\
3666\end{array}$ & $\begin{array}{r}1832 \\
155 \\
2003 \\
2005\end{array}$ & $\begin{array}{l}1006 \\
2171 \\
2171 \\
1006\end{array}$ & $\begin{array}{l}1073 \\
2145 \\
2145 \\
1667 \\
1189 \\
1189 \\
1188 \\
1188 \\
1198 \\
1188 \\
1189 \\
2145 \\
2145 \\
2145 \\
4318\end{array}$ & $\begin{array}{r}630 \\
1260 \\
1260 \\
630\end{array}$ & $\begin{array}{l}230 \\
230 \\
230 \\
230 \\
230 \\
230 \\
230 \\
230 \\
230 \\
230 \\
230 \\
230 \\
230 \\
230 \\
230 \\
230 \\
230 \\
230\end{array}$ & $\begin{array}{l}4191 \\
1759 \\
7296 \\
9690 \\
4546 \\
4546 \\
2993 \\
1418 \\
1418 \\
1418 \\
1418 \\
1418 \\
1418 \\
1418 \\
2375 \\
2375 \\
2375 \\
4548\end{array}$ & $\begin{array}{c}4191 \\
1691 \\
6746 \\
7725 \\
3886 \\
3736 \\
2358 \\
1078 \\
1036 \\
996 \\
958 \\
921 \\
806 \\
652 \\
1372 \\
1319 \\
1268 \\
2335\end{array}$ \\
\hline TOTAL & 9002 & 6075 & 6514 & 26099 & 3780 & 4140 & 55610 & 43354 \\
\hline
\end{tabular}

- Decommissioning Cost

INITIAL FAYMENT = $24 \$$ \$KGU (INCLUDES $\$ 5 / K g U$ IMFACT AID)

FINAL PAYMENT $=246$ \$KOU (INCLUDES $\$ 10 / \mathrm{KgU}$ IMFACT AID)

TABLE A10-55

COST SENSITIVITY CASE -- 6\% 0ISCOUNT RATE

ESTIMATED SPENDING SCHEDULE FOR STORAGE OF 236 DRYWELLS ( 100 MTU) AT GOVERNMENT SITE WITH EXISTING FACILITIES

(\$000, 1989)

\begin{tabular}{|c|c|c|c|c|c|c|c|c|}
\hline YEAR & $\begin{array}{l}\text { IRANS } \\
\text { FACIL } \\
\text { COSTS }\end{array}$ & $\begin{array}{l}\text { STOR } \\
\text { AREA } \\
\text { COSTS }\end{array}$ & $\begin{array}{r}\text { MODULE } \\
\text { COSTS }\end{array}$ & $\begin{array}{r}\text { DPERAT } \\
\text { COSTS }\end{array}$ & $\begin{array}{l}\text { FIS } \\
\text { DEVEL } \\
\text { COSTS }\end{array}$ & $\begin{array}{l}\text { GOVT. } \\
\text { ADMIN } \\
\text { COSTS }\end{array}$ & $\begin{array}{l}\text { TOTAL } \\
\text { COSTS }\end{array}$ & $\begin{array}{l}\text { DISC. } \\
\text { TOIAL } \\
\text { COSTS }\end{array}$ \\
\hline $\begin{array}{l}1989 \\
1990 \\
1991 \\
1992 \\
1993 \\
1994 \\
1995 \\
1996 \\
1997 \\
1998 \\
1999 \\
2000 \\
2001 \\
2002 \\
2003 \\
2004 \\
2005 \\
2006\end{array}$ & $\begin{array}{r}1499 \\
114 \\
3723 \\
3666\end{array}$ & $\begin{array}{r}1832 \\
155 \\
2083 \\
2005\end{array}$ & $\begin{array}{l}1086 \\
2171 \\
2171 \\
1086\end{array}$ & $\begin{array}{l}1073 \\
2145 \\
2145 \\
1667 \\
1189 \\
1189 \\
1188 \\
1198 \\
1189 \\
1198 \\
1189 \\
2145 \\
2145 \\
2145 \\
4318\end{array}$ & $\begin{array}{r}630 \\
1260 \\
1260 \\
630\end{array}$ & $\begin{array}{l}230 \\
230 \\
230 \\
230 \\
230 \\
230 \\
230 \\
230 \\
230 \\
230 \\
230 \\
230 \\
230 \\
230 \\
230 \\
230 \\
230 \\
230\end{array}$ & $\begin{array}{l}4191 \\
1759 \\
7296 \\
8690 \\
4346 \\
4546 \\
2983 \\
1418 \\
1419 \\
1419 \\
1418 \\
1418 \\
1418 \\
1416 \\
2375 \\
2375 \\
2375 \\
4549\end{array}$ & $\begin{array}{r}4191 \\
1659 \\
6493 \\
7296 \\
3601 \\
3397 \\
2103 \\
943 \\
890 \\
939 \\
792 \\
747 \\
705 \\
665 \\
1050 \\
791 \\
935 \\
1689\end{array}$ \\
\hline TOTAL & 9002 & 6075 & 6514 & 26099 & 3780 & 4140 & 55610 & 38906 \\
\hline
\end{tabular}

* - dECOMAISSIONING COST

INITIAL PAYMENT * $229 * / \mathrm{KgU}$ (INCLUDES * $3 / \mathrm{KgU}$ IMPACT AID)

FINAL PAYMENT = 225 "KgU (INCLUDES * 10/KgU IMFACT AID) 
TABLE A10-56

COST SENSITIVITY CASE -. 43 DISCOUNT RATE

ESTIMATED SPENDING SCHEDULE FOR STORAGE OF 4479 DRYWELLS (1900 MTU) AT GOVERNMENT SITE WITH EXISTING FACILITIES

(\$000, 1989)

\begin{tabular}{|c|c|c|c|c|c|c|c|c|}
\hline YEAR & $\begin{array}{l}\text { TRANS } \\
\text { FACIL } \\
\text { COSTS }\end{array}$ & $\begin{array}{l}\text { STDR } \\
\text { AREA } \\
\text { COSTS }\end{array}$ & $\begin{array}{r}\text { MODULE } \\
\text { CDSTS }\end{array}$ & $\begin{array}{r}\text { QPERAT } \\
\text { COSTS }\end{array}$ & $\begin{array}{l}\text { F IS } \\
\text { DEVEL } \\
\text { COSTS }\end{array}$ & $\begin{array}{l}\text { GOUT. } \\
\text { ADHIN } \\
\text { COSTS }\end{array}$ & $\begin{array}{l}\text { TOTAL } \\
\text { COSTS }\end{array}$ & $\begin{array}{l}\text { DISC. } \\
\text { TOTAL } \\
\text { COSTS }\end{array}$ \\
\hline $\begin{array}{l}1999 \\
1990 \\
1991 \\
1992 \\
1993 \\
1994 \\
1995 \\
1996 \\
1997 \\
1990 \\
1999 \\
2000 \\
2001 \\
2002 \\
2003 \\
2004 \\
2005 \\
2006\end{array}$ & $\begin{array}{r}1499 \\
114 \\
3723 \\
3666\end{array}$ & $\begin{array}{r}2298 \\
155 \\
3603 \\
3525\end{array}$ & $\begin{array}{l}20600 \\
41201 \\
41201 \\
20600\end{array}$ & $\begin{array}{c}3815 \\
7630 \\
7630 \\
4776 \\
1922 \\
1922 \\
1922 \\
1922 \\
1922 \\
1922 \\
1922 \\
7630 \\
7630 \\
7630 \\
28435\end{array}$ & $\begin{array}{r}630 \\
1260 \\
1260 \\
630\end{array}$ & $\begin{array}{l}900 \\
900 \\
900 \\
900 \\
900 \\
900 \\
900 \\
900 \\
900 \\
900 \\
900 \\
900 \\
900 \\
900 \\
900 \\
900 \\
900 \\
900\end{array}$ & $\begin{array}{r}5317 \\
2429 \\
9486 \\
33136 \\
49731 \\
49731 \\
26276 \\
2922 \\
2822 \\
2922 \\
2922 \\
2822 \\
2822 \\
2922 \\
6530 \\
9530 \\
8530 \\
29335\end{array}$ & $\begin{array}{r}5317 \\
2336 \\
0770 \\
29458 \\
42510 \\
40875 \\
20766 \\
2144 \\
2062 \\
1993 \\
1906 \\
1933 \\
1763 \\
1695 \\
4926 \\
4736 \\
4554 \\
15060\end{array}$ \\
\hline TOTAL & 9002 & 9571 & 123602 & 89630 & 3780 & 16200 & 250785 & 192694 \\
\hline
\end{tabular}

* - Decommissioning cost

INITIAL PAYHENT $=71 / \mathrm{KgU}$ (INCLUDES * 4/KgU IMPACT AID)

FINAL PAYMENT = 49 KOU (INCLUDES $*$ G/KgU IMPACT AID)

TABLE A10.57

COST SENSIYIVITY CASE $\because 6 \%$ DISCOUNT RATE

ESTIMATED SPENDING SCHEDULE FOR STORAGE OF 4479 DRYWELLS ( $1900 \mathrm{MTU})$ AT GOVERNMENT SITE WITH EXISTINL FACILITIES

$(\$ 000,1989)$

\begin{tabular}{|c|c|c|c|c|c|c|c|c|}
\hline YEAR & $\begin{array}{l}\text { TRANS } \\
\text { FACIL } \\
\text { COSTS }\end{array}$ & $\begin{array}{l}\text { STOR } \\
\text { AREA } \\
\text { COSTS }\end{array}$ & $\begin{array}{r}\text { MODULE } \\
\text { COSTS }\end{array}$ & $\begin{array}{r}\text { OFERAT } \\
\text { COSTS }\end{array}$ & $\begin{array}{l}\text { FIS } \\
\text { DEVEL } \\
\text { COSTS }\end{array}$ & $\begin{array}{l}\text { GOVT } \\
\text { ADMIN } \\
\text { CDSTS }\end{array}$ & $\begin{array}{l}\text { TOTAL } \\
\text { COSTS }\end{array}$ & $\begin{array}{l}\text { DISC. } \\
\text { TDTAL } \\
\text { COSTS }\end{array}$ \\
\hline$\overline{1989}$ & 1499 & 2280 & & & 630 & 900 & 5317 & $5 \longdiv { 3 1 7 }$ \\
\hline 1990 & 114 & 155 & & & 1260 & 900 & 2429 & 2292 \\
\hline 1991 & 3723 & 3603 & & & 1260 & 900 & 9486 & 9443 \\
\hline 1992 & 3666 & 3525 & 20600 & 3815 & 630 & 900 & 33136 & 27822 \\
\hline 1993 & & & 41201 & 7630 & & 900 & 49731 & 39392 \\
\hline 2994 & & & 41201 & 7630 & & 900 & $497 J 1$ & 37162 \\
\hline 1995 & & & 20600 & 4776 & & 900 & 26276 & 19524 \\
\hline 1996 & & & & 1922 & & 900 & 2822 & 1877 \\
\hline 1997 & & & & 1922 & & 900 & 2822 & 1771 \\
\hline 1998 & & & & 1922 & & 900 & 2822 & 1670 \\
\hline 1999 & & & & 1922 & & 900 & 2822 & 1576 \\
\hline 2000 & & & & 1922 & & 900 & 2822 & 1487 \\
\hline 2001 & & & & 1922 & & 900 & 2822 & 1402 \\
\hline 2002 & & & & 1922 & & 900 & 2822 & 1323 \\
\hline 2003 & & & & 7630 & & 900 & 8530 & 3773 \\
\hline 2004 & & & & 7630 & & 900 & 8530 & 3559 \\
\hline 2005 & & & & 7630 & & 900 & 8930 & 3358 \\
\hline 2006 & & & & 26435 & & 900 & 29335 & 10874 \\
\hline TOTAL & 9002 & 9571 & $\overline{123602}$ & 98630 & 3780 & 16200 & 250785 & 171642 \\
\hline
\end{tabular}

* - DECOMMISSIONING COST

INITIAL PAYMENT = 66 \$KOU (INCLUDES $\$ 4 / \mathrm{KgU}$ IMPACT AID)

FINAL PAYMENT * 45 \$KUU (INCLUDES * $8 / K g U$ IMPACT AID) 
10.5 IMPACT OF NRC LICENSING STATUS

The impact on FIS costs of not having to license a FIS facility through the NRC is shown in Table A10-58. In this table the cost impact is shown separately for (i) not having to go through the formal NRC review of a safety analysis report, and hearings on construction and operation, but rather having internal DOE reviews only, (ii) not having to implement NRC security regulations but rather using the security protection afforded the existing site, and (iii) a combination of (i) and (ii).

TABLE A10-58

IMPACT ON FIS SYSTEM COSIS OF NOT HAVING TO LICENSE FIS FACILITIES

\begin{tabular}{|c|c|c|c|c|}
\hline & \multicolumn{2}{|c|}{$100 \mathrm{NTU}$} & \multicolumn{2}{|c|}{$1900 \mathrm{MTU}$} \\
\hline & $\begin{array}{c}\text { Total } \\
\text { Discounted } \\
\text { Cost }(\$ 000)\end{array}$ & $\begin{array}{c}\text { Total } \\
\text { Unit } \\
\text { Cost }(S / \mathrm{kgU})\end{array}$ & $\begin{array}{c}\text { Total } \\
\text { Oiscounted } \\
\text { Cost }(5000)\end{array}$ & $\begin{array}{c}\text { Total } \\
\text { Unit } \\
\text { Cost }(\$ / \mathrm{kgu}) \\
\end{array}$ \\
\hline \multicolumn{5}{|l|}{ New Transfer Facility Cases } \\
\hline $\begin{array}{l}\text { Fuil NRC Llcensing } \\
\text { (Base Case) }\end{array}$ & $\$ 68,659$ & $\$ 730$ & $\$ 242,158$ & $\$ 146$ \\
\hline No NRC Licensing Activites & 66.766 & 711 & 240,273 & 145 \\
\hline Savings & 1,893 & 19 & 1.885 & 1 \\
\hline No NRC Security & 58,569 & 620 & 232,064 & 139 \\
\hline Savings & 10,090 & 110 & 10.094 & 7 \\
\hline $\begin{array}{l}\text { No NRC licensing or } \\
\text { Security }\end{array}$ & 56,679 & 601 & 230,182 & 138 \\
\hline Savings & 11,980 & 129 & 11.976 & 8 \\
\hline \multicolumn{5}{|l|}{$\begin{array}{l}\text { Existing Transfer Facility } \\
\text { Cases }\end{array}$} \\
\hline $\begin{array}{l}\text { Fuil MRC Licensing } \\
\text { (Base Case) }\end{array}$ & $\$ 48.775$ & $\$ 525$ & $\$ 218, \$ 45$ & $\$ 131$ \\
\hline No NRC Licensing Activites & 47.688 & 514 & 217.467 & 130 \\
\hline Savings & 1.087 & 11 & 1.078 & 1 \\
\hline No NRC Security & 38,689 & 415 & 208,458 & 125 \\
\hline Savings & $! 0,086$ & 110 & 10,087 & 6 \\
\hline $\begin{array}{l}\text { No NRC Licensing or } \\
\text { Security }\end{array}$ & 37,610 & 404 & 207,380 & 125 \\
\hline Savings & 11.165 & 121 & 11.165 & 6 \\
\hline
\end{tabular}

The estimated spending schedules, discounted annual costs, and the calculation of the Initial and Final Payments for FIS of spent fuel for each of the cases considered in Table A10-58 are set forth in Tables A10-59 through A10-70. 
TABLE A10-59

COST SENSITIVITY CASE - NO NRC LICENSING

ESTIMATED SPENDING SCHEDULE FOR STORAGE OF 236 DRYWELLS ( 100 MTU) AT GOVERNMENT SITE WITHOUT EXISTING FACILITIES

$(\$ 000,1989)$

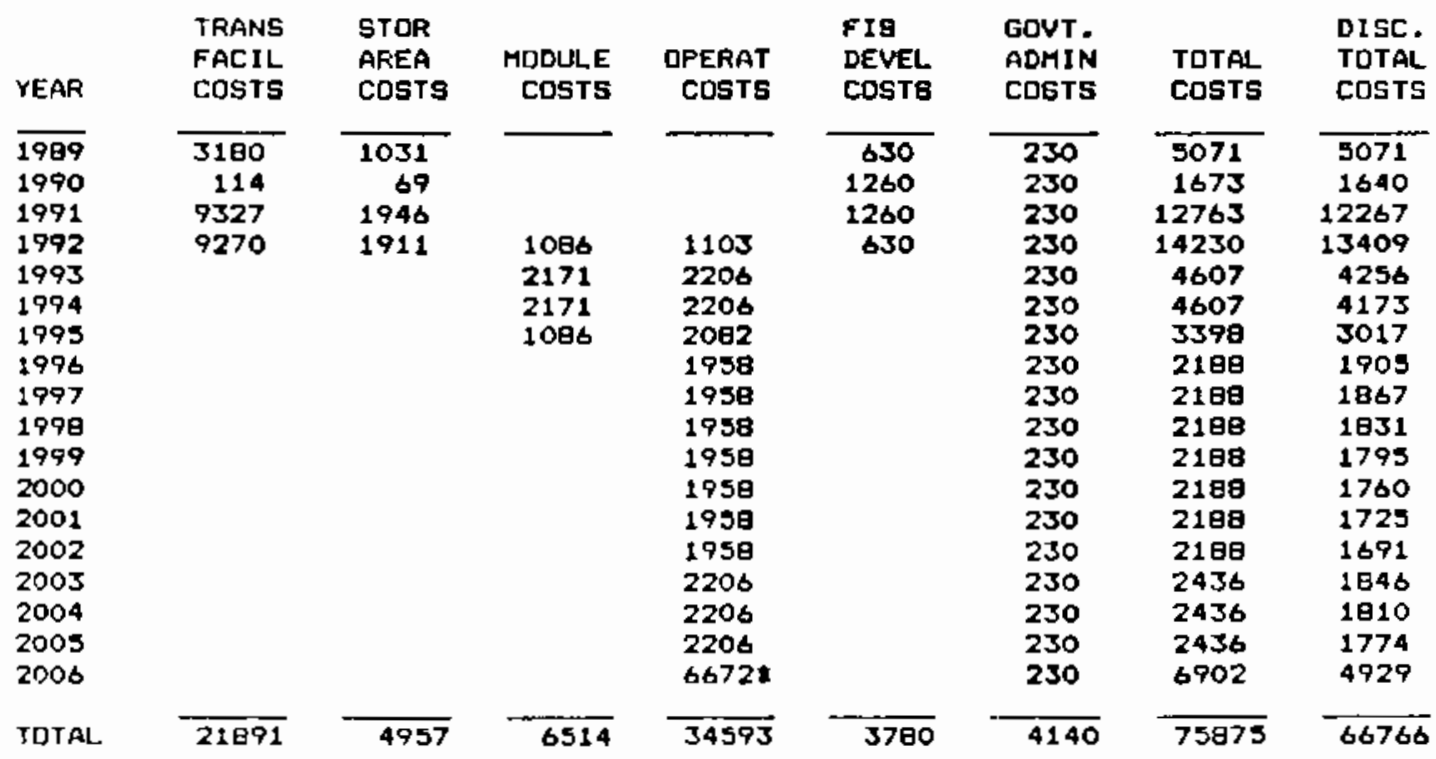

* - Decommissioning cost

INITIAL PAYMENT = $367 * / K g U$ (INCLUDES * 5/KgU IMPACT AID)

FINAL PAYMENT = 344 \&KUU (INCLUDES * 10/KgU IMPACT AID)

TABLE A10-60

COST SENSITIVITY CASE .. NO NRC SECURITY

ESTIMATED SFENDING SCHEDULE FOR STORAGE OF 236 DRYWELLS ( $100 \mathrm{MTU}$ ) AT GOVERNMENT SITE WITHDUT EXISTING FACILITIES

$(1000,1989)$

\begin{tabular}{|c|c|c|c|c|c|c|c|c|}
\hline YEAR & $\begin{array}{l}\text { TRANS } \\
\text { FACIL } \\
\text { COSTS }\end{array}$ & $\begin{array}{l}\text { STOR } \\
\text { AREA } \\
\text { COSTS }\end{array}$ & $\begin{array}{r}\text { MODULE } \\
\text { CDSTS }\end{array}$ & $\begin{array}{r}\text { OPERAT } \\
\text { COSTS }\end{array}$ & $\begin{array}{l}\text { FIS } \\
\text { DEVEL } \\
\text { COSTS }\end{array}$ & $\begin{array}{l}\text { GOUT } \\
\text { ADMIN } \\
\text { COSTS }\end{array}$ & $\begin{array}{l}\text { TOTAL } \\
\text { COSTS }\end{array}$ & $\begin{array}{l}\text { DISC, } \\
\text { TOTAL } \\
\text { COSTS }\end{array}$ \\
\hline $\begin{array}{l}1989 \\
1990\end{array}$ & $\begin{array}{r}3654 \\
249\end{array}$ & $\begin{array}{r}1004 \\
153\end{array}$ & & & $\begin{array}{r}630 \\
1260\end{array}$ & $\begin{array}{l}230 \\
230\end{array}$ & $\begin{array}{l}6318 \\
1894\end{array}$ & $\begin{array}{l}6318 \\
1857\end{array}$ \\
\hline 1991 & 9395 & 1989 & & & 1260 & 230 & 12874 & 12374 \\
\hline $\begin{array}{l}1992 \\
1993\end{array}$ & 9270 & 1911 & $\begin{array}{l}1096 \\
2171\end{array}$ & $\begin{array}{r}655 \\
1310\end{array}$ & 630 & $\begin{array}{l}230 \\
230\end{array}$ & $\begin{array}{r}13782 \\
3711\end{array}$ & $\begin{array}{r}12987 \\
3428\end{array}$ \\
\hline 1994 & & & 2171 & 1310 & & 230 & 3711 & 3361 \\
\hline 1995 & & & 1086 & 1187 & & 230 & 2503 & 2223 \\
\hline 1996 & & & & 1063 & & 230 & 1293 & 1226 \\
\hline 1997 & & & & 1063 & & 230 & 1293 & 1104 \\
\hline 1998 & & & & 1063 & & 230 & 1293 & 1082 \\
\hline 1999 & & & & 1063 & & 230 & 1293 & 1061 \\
\hline 2000 & & & & 1063 & & 230 & 1293 & 1040 \\
\hline 2001 & & & & 1063 & & 230 & 1293 & 1020 \\
\hline 2002 & & & & 1063 & & 230 & 1293 & 1000 \\
\hline 2003 & & & & 1310 & & 230 & 1540 & 1167 \\
\hline 2004 & & & & 1310 & & 230 & 1540 & 1144 \\
\hline 2005 & & & & 1310 & & 230 & 1540 & 1122 \\
\hline 2006 & & & & 6998 & & 230 & 7218 & 5155 \\
\hline TOTAL. & 22568 & 5859 & 6514 & 22821 & 3780 & 4140 & 65682 & 58569 \\
\hline
\end{tabular}

* - decommisstaning cost

INITIAL PAYMENT $=382 * / \mathrm{KgU}$ (INCLUDES $5 / \mathrm{KgU}$ IMPACT AID)

FINAL PAYMENT - 238 \$KGU (INCLUDES * 10/KgU IMPACT AID) 
TABLE A10-61

COSI SENSITIVITY CASE -- NO NRC LICENSING OR SECURITY

ESTIMATED SPENDING SCHEDULE FOR STORAGE OF 236 DRYWELLG (100 MTU)

AT GOVERNMENT SITE WITHOUT EXISTINO FACILITIES

$(1000,1999)$

\begin{tabular}{|c|c|c|c|c|c|c|c|c|c|}
\hline YEAR & & $\begin{array}{l}\text { TRANS } \\
\text { FACIL } \\
\text { COSTS }\end{array}$ & $\begin{array}{l}\text { STOR } \\
\text { AREA } \\
\text { COSTS }\end{array}$ & $\begin{array}{r}\text { MODULE } \\
\text { COSTS }\end{array}$ & $\begin{array}{r}\text { OPERAT } \\
\text { COSTS }\end{array}$ & $\begin{array}{l}\text { F IS } \\
\text { DEVEL } \\
\text { COSTS }\end{array}$ & $\begin{array}{l}\text { GOVT. } \\
\text { ADMIN } \\
\text { COSTS }\end{array}$ & $\begin{array}{l}\text { TOTAL } \\
\text { COSTS }\end{array}$ & $\begin{array}{l}\text { DISC. } \\
\text { TOTAL } \\
\text { COSTS }\end{array}$ \\
\hline $\begin{array}{l}1999 \\
1990\end{array}$ & - & $\begin{array}{r}3180 \\
114\end{array}$ & $\begin{array}{r}1031 \\
69\end{array}$ & & & $\begin{array}{r}630 \\
1260\end{array}$ & $\begin{array}{l}230 \\
230\end{array}$ & $\begin{array}{l}5071 \\
1673\end{array}$ & $\begin{array}{l}5071 \\
1640\end{array}$ \\
\hline 1991 & & 9327 & 1946 & & & 1260 & 230 & 12763 & 12267 \\
\hline $\begin{array}{l}1992 \\
1993\end{array}$ & & 9270 & 1911 & $\begin{array}{l}1086 \\
2171\end{array}$ & $\begin{array}{r}651 \\
1302\end{array}$ & 630 & $\begin{array}{l}230 \\
230\end{array}$ & $\begin{array}{r}13778 \\
3703\end{array}$ & $\begin{array}{r}12983 \\
3421\end{array}$ \\
\hline 1994 & & & & 2171 & 1302 & & 230 & 3703 & 3354 \\
\hline 1993 & & & & 1096 & 1179 & & 230 & 2495 & 2213 \\
\hline 1996 & & & & & 1055 & & 230 & 1285 & 1119 \\
\hline 1997 & & & & & 1055 & & 230 & 1285 & 1097 \\
\hline 1998 & & & & & 1055 & & 230 & 1285 & 1075 \\
\hline 1999 & & & & & 1055 & & 230 & 1283 & 1054 \\
\hline 2000 & , & & & & 1055 & & 230 & 1285 & 1035 \\
\hline 2001 & & & & & 1055 & & 230 & 1285 & 1013 \\
\hline 2002 & & & & & 1055 & & 230 & 1285 & 993 \\
\hline 2003 & & & & & 1302 & & 230 & 1532 & 1161 \\
\hline 2004 & & & & & 1302 & & 230 & 1532 & 1139 \\
\hline 2005 & & & & & 1302 & & 230 & 1532 & 1116 \\
\hline 2006 & & & & & $6672 t$ & & 230 & 6902 & 4929 \\
\hline TOTAL & & 21091 & 4957 & 6514 & 22397 & 3780 & 4140 & 63679 & 56679 \\
\hline
\end{tabular}

* Decomissioning cost

INITIAL PAYMENT $=367 \% / K g U$ (INCLUDES $\$ / K Q U$ IMPACT AID)

FINAL PAYMENT $=234$ $/ K g U$ (INCLUDES $* 10 / \mathrm{KgU}$ IMPACT AID)

TABLE A10-62

COST SENSITIVITY CASE - NO NRC LICENSING

ESTIMATED SFENDING SCHEDULE FOR STORAGE CF 4478 DRYWELLS (1900 MTU) AT GOVERNMENT SITE WITHOUT EXISTING FACILITIES

$(\$ 000,1989)$

\begin{tabular}{|c|c|c|c|c|c|c|c|c|}
\hline YEAK & $\begin{array}{l}\text { TRANS } \\
\text { FACIL } \\
\text { COSTS }\end{array}$ & $\begin{array}{l}\text { STOR } \\
\text { AREA } \\
\text { COSTS }\end{array}$ & $\begin{array}{r}\text { MODULE } \\
\text { CDSTS }\end{array}$ & $\begin{array}{r}\text { OPERAT } \\
\text { COSTS }\end{array}$ & $\begin{array}{l}\text { FIS } \\
\text { DEVEL } \\
\text { COSTS }\end{array}$ & $\begin{array}{l}\text { GOVT. } \\
\text { ADHIN } \\
\text { CDSTS }\end{array}$ & $\begin{array}{l}\text { TOTAL } \\
\text { COSTS }\end{array}$ & $\begin{array}{l}\text { DISC. } \\
\text { TOTAL } \\
\text { COSTS }\end{array}$ \\
\hline $\begin{array}{l}1909 \\
1990\end{array}$ & $\begin{array}{r}3180 \\
114\end{array}$ & $\begin{array}{r}1488 \\
69\end{array}$ & & & $\begin{array}{r}630 \\
1260\end{array}$ & $\begin{array}{l}900 \\
900\end{array}$ & $\begin{array}{l}6198 \\
2343\end{array}$ & $\begin{array}{l}6190 \\
2297\end{array}$ \\
\hline 1991 & 9327 & 3466 & & & 1260 & 900 & 14953 & 14372 \\
\hline $\begin{array}{l}1992 \\
1993\end{array}$ & 9270 & 3432 & $\begin{array}{l}20600 \\
41201\end{array}$ & $\begin{array}{l}3846 \\
7691\end{array}$ & 630 & $\begin{array}{l}900 \\
900\end{array}$ & $\begin{array}{l}39679 \\
49792\end{array}$ & $\begin{array}{l}36447 \\
46000\end{array}$ \\
\hline 1994 & & & 41201 & 7691 & & 900 & 49792 & 45098 \\
\hline 1995 & & & 20600 & 5493 & & 900 & 26993 & $\begin{array}{r}23969 \\
3652\end{array}$ \\
\hline 1996 & & & & 3295 & & 900 & 4193 & $\begin{array}{l}3652 \\
3580\end{array}$ \\
\hline $\begin{array}{l}1997 \\
1998\end{array}$ & & & & $\begin{array}{l}3295 \\
3295\end{array}$ & & $\begin{array}{l}900 \\
900\end{array}$ & $\begin{array}{l}4195 \\
4195\end{array}$ & $\begin{array}{l}3580 \\
3510\end{array}$ \\
\hline 1999 & & & & 3293 & & 900 & 4195 & 3441 \\
\hline 2000 & & & & 3295 & & 900 & 4195 & 3374 \\
\hline 2001 & & & & 3295 & & 900 & 4195 & 3308 \\
\hline 2002 & & & & 3295 & & 900 & 4195 & 3243 \\
\hline 2003 & & & & 7691 & & 900 & 8591 & 6511 \\
\hline 2004 & & & & 7691 & & 900 & 8591 & 6383 \\
\hline 2005 & & & & 7691 & & 900 & 8591 & 6258 \\
\hline 2006 & & & & 30790 & & 900 & 31690 & 22632 \\
\hline TDTAL & 21891 & $\overline{8455}$ & 123602 & $\overline{101649}$ & 3780 & 16200 & $\overline{275577}$ & 240273 \\
\hline
\end{tabular}

* - Decommissioning cost

INITIAL PAYMENT $\approx 83 * / K g U$ (INCLUDES * 5/KgU IMPACT AID)

FINAL PAYMENT $=62$ *KGU (INCLUDES * $9 / \mathrm{KgU}$ IMPACT AID) 
IABLE A10-63

COST SENSITIVITY CASE -- NO NRC SECURITY

ESTIMATED SFENDING SCHEDULE FOR STORAGE OF 4479 DRYWELLS ( 1900 MTU)

AT GOUERNMENT SITE HITHDUT EXISTING FACILITIES

$(\$ 000,1989)$

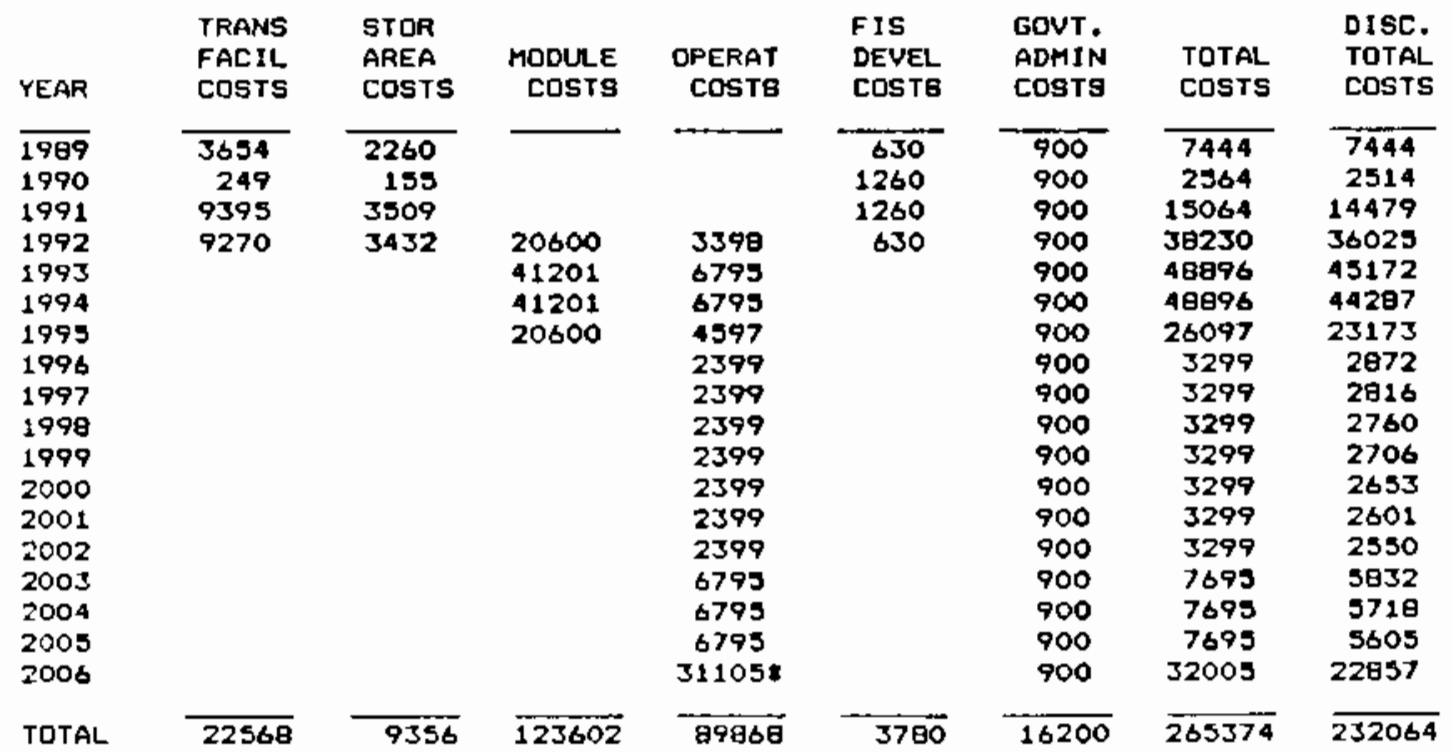

* Decommissioning COST

INITIAL PAYMENT $=63 * / K Q U$ (INCLUDES $\$ 4 / \mathrm{KgU}$ IMPACT AID)

FINAL PAYMENT = 56 \&KQU (INCLUDES $\$ / K Q U$ IMPACT AID)

TABLE A10-64

COST SENSITIVITY CASE - NO NRC LICENSING OR SECURITY

ESTIMATED SPENDING SCHEDULE FOR STORAGE OF 4479 DRYWELLS ( 1900 MTU)

AT GOUERNMENT SITE HITHOUT EXISTING FACILITIES

$(\$ 000,1989)$

\begin{tabular}{|c|c|c|c|c|c|c|c|c|}
\hline YEAR & $\begin{array}{l}\text { TRANS } \\
\text { FACIL } \\
\text { COSTS }\end{array}$ & $\begin{array}{l}\text { STOR } \\
\text { AREA } \\
\text { COSTS }\end{array}$ & $\begin{array}{r}\text { MODULE } \\
\text { COSTS }\end{array}$ & $\begin{array}{r}\text { DPERAT } \\
\text { COSTS }\end{array}$ & $\begin{array}{l}\text { FIS } \\
\text { DEVEL } \\
\text { COSTS }\end{array}$ & $\begin{array}{l}\text { GOVT. } \\
\text { ADMIN } \\
\text { COSTS }\end{array}$ & $\begin{array}{l}\text { TOTAL } \\
\text { COSTS }\end{array}$ & $\begin{array}{l}\text { DISC. } \\
\text { TOTAL } \\
\text { COSTS }\end{array}$ \\
\hline $\begin{array}{l}19 \overline{909} \\
1990\end{array}$ & $\begin{array}{r}3180 \\
114\end{array}$ & $\begin{array}{r}1498 \\
69\end{array}$ & & & $\begin{array}{r}630 \\
1260\end{array}$ & $\begin{array}{l}900 \\
900\end{array}$ & $\begin{array}{l}6196 \\
2343\end{array}$ & $\begin{array}{l}6198 \\
2297\end{array}$ \\
\hline 1991 & 9327 & 3466 & & - & 1260 & 900 & 14953 & 14372 \\
\hline 1992 & 9270 & 3432 & 20800 & 3394 & 630 & 900 & 38226 & 36021 \\
\hline 1993 & & & 41201 & 6707 & & 900 & $48 \theta 8 \theta$ & 45165 \\
\hline 1994 & & & 41201 & 6787 & & 900 & 48889 & 44279 \\
\hline 1995 & & & 20600 & 4589 & & 900 & 26099 & 23166 \\
\hline 1996 & & & & 2391 & & 900 & 3291 & 2865 \\
\hline 1997 & & & & 2391 & & 900 & 3291 & 2809 \\
\hline 1998 & & & & 2391 & & 900 & 3291 & 2754 \\
\hline 1999 & & & & 2391 & & 900 & 3291 & 2700 \\
\hline 2000 & & & & 2391 & & 900 & 3291 & 2647 \\
\hline 2001 & & & & 2391 & & 700 & 3291 & 2595 \\
\hline 2002 & & & & 2391 & & 900 & 3291 & 2544 \\
\hline 2003 & & & & 6787 & & 700 & 7687 & 5826 \\
\hline 2004 & & & & 6707 & & 900 & 7687 & 5712 \\
\hline 2005 & & & & 6797 & & 900 & 7687 & 5600 \\
\hline 2006 & & & & $30790 \%$ & & 900 & 31690 & 22632 \\
\hline TOTAL & 21891 & 8455 & 123602 & 89445 & 3780 & 16200 & 263373 & $\overline{230182}$ \\
\hline
\end{tabular}

* - decommissioning cost

INITIAL PAYMENT a 92 :KgU (INCLUDES * A/KgU IMPACT AID)

FINAL PAYMENT = J6 \$KgU (INCLUDES $9 / \mathrm{KgU}$ IMPACT AID) 
TABLE A10-65

COST SENSITIVITY CASE -. NO NRC LICENSING

ESTIMATED SPENDING SCHEDULE FOR STORAGE OF 236 DRYWELLS ( 100 MTU) AT GOVERNMENT SITE WITH EXISTING FACILITIES

$(* 000,1989)$

\begin{tabular}{|c|c|c|c|c|c|c|c|c|}
\hline YEAR & $\begin{array}{l}\text { TRANS } \\
\text { FACIL } \\
\text { COSTS }\end{array}$ & $\begin{array}{l}\text { STOR } \\
\text { AREA } \\
\text { COSTS }\end{array}$ & $\begin{array}{r}\text { MODULE } \\
\text { COSTS }\end{array}$ & $\begin{array}{r}\text { OPERAT } \\
\text { CDSTB }\end{array}$ & $\begin{array}{l}\text { FIS } \\
\text { DEVEL } \\
\text { COSTS }\end{array}$ & $\begin{array}{l}\text { GOVT. } \\
\text { ADHIN } \\
\text { COSTS }\end{array}$ & $\begin{array}{l}\text { TOTAL } \\
\text { COSTS }\end{array}$ & $\begin{array}{l}\text { DISC, } \\
\text { TOTAL } \\
\text { COSTS }\end{array}$ \\
\hline $\begin{array}{l}1909 \\
1990 \\
1991 \\
1992 \\
1993 \\
1994 \\
1995 \\
1996 \\
1997 \\
1990 \\
1999 \\
2000 \\
2001 \\
2002 \\
2003 \\
2004 \\
2005 \\
2006\end{array}$ & $\begin{array}{r}1499 \\
114 \\
3723 \\
3666\end{array}$ & $\begin{array}{r}1060 \\
69 \\
2039 \\
2005\end{array}$ & $\begin{array}{l}1086 \\
2171 \\
2171 \\
1086\end{array}$ & $\begin{array}{l}1070 \\
2140 \\
2140 \\
1662 \\
1183 \\
1183 \\
1183 \\
1183 \\
1193 \\
1183 \\
1183 \\
2140 \\
2140 \\
2140 \\
4138 *\end{array}$ & $\begin{array}{r}630 \\
1260 \\
1260 \\
630\end{array}$ & $\begin{array}{l}230 \\
230 \\
230 \\
230 \\
230 \\
230 \\
230 \\
230 \\
230 \\
230 \\
230 \\
230 \\
230 \\
230 \\
230 \\
230 \\
230 \\
230\end{array}$ & $\begin{array}{l}3419 \\
1673 \\
7252 \\
9697 \\
4541 \\
4541 \\
2978 \\
1413 \\
1413 \\
1413 \\
1413 \\
1413 \\
1413 \\
1413 \\
2370 \\
2370 \\
2370 \\
4368\end{array}$ & $\begin{array}{l}3419 \\
1640 \\
6970 \\
8186 \\
4195 \\
4113 \\
2644 \\
1230 \\
1206 \\
1182 \\
1159 \\
1136 \\
1114 \\
1092 \\
1796 \\
1761 \\
1726 \\
3119\end{array}$ \\
\hline TOTAL. & 9002 & 5173 & 6514 & $\overline{25851}$ & 3780 & 4140 & 54460 & 47608 \\
\hline
\end{tabular}

* - Decommissioning Cost

INITIAL PAYMENT $=244$ * KOU (INCLUDES $* 3 / \mathrm{KgU}$ IMPACT AID)

FINAL PAYMENT = 270 KOU (INCLUDES $10 / \mathrm{KOU}$ IMPACT AID)

TABLE A10-66

COST SENSITIVITY CASE -. NO NRC SECURITY ESTIMATED SPENDING SCHEDULE FOR STORAGE OF 236 DRYWELLS ( 100 MTU) AT GOVERNMENT SITE WITH EXISTING FACILITIES (\$000, 1989)

\begin{tabular}{|c|c|c|c|c|c|c|c|c|}
\hline YEAR & $\begin{array}{l}\text { TRANS } \\
\text { FACIL } \\
\text { COSTS }\end{array}$ & $\begin{array}{l}\text { STOR } \\
\text { AREA } \\
\text { COSTS }\end{array}$ & $\begin{array}{r}\text { MODULE } \\
\text { COSTS }\end{array}$ & $\begin{array}{r}\text { OPERAT } \\
\text { COSTS }\end{array}$ & $\begin{array}{l}\text { FIS } \\
\text { DEVEL } \\
\text { COSTS }\end{array}$ & $\begin{array}{l}\text { GDVT. } \\
\text { ADMIN } \\
\text { COSTS }\end{array}$ & $\begin{array}{l}\text { TOTAL } \\
\text { COSTS }\end{array}$ & $\begin{array}{l}\text { DISC. } \\
\text { TOTAL } \\
\text { COSTS }\end{array}$ \\
\hline 1909 & 1499 & 2032 & & & 630 & 230 & 4191 & 4191 \\
\hline 1990 & 114 & 155 & & & 1260 & 230 & 1759 & 1725 \\
\hline 1991 & 3723 & 2083 & & & 1260 & 230 & 7296 & 7013 \\
\hline 1992 & 3666 & 2005 & 1086 & 621 & 630 & 230 & 0238 & 7763 \\
\hline 1993 & & & 2171 & 1241 & & 230 & 3642 & 3365 \\
\hline 1994 & & & 2871 & 1241 & & 230 & 3642 & 3299 \\
\hline 1995 & & & 1086 & 763 & & 230 & 2079 & 1846 \\
\hline 1998 & & & & 283 & & 230 & 515 & $44 B$ \\
\hline 1997 & & & & 285 & & 230 & 515 & 440 \\
\hline 1990 & & & & 285 & & 230 & 515 & 431 \\
\hline 1999 & & & & 205 & & 230 & 515 & 422 \\
\hline 2000 & & & & 285 & & 230 & 515 & 414 \\
\hline $200:$ & & & & 205 & & 230 & 515 & 408 \\
\hline 2002 & & & & 285 & & 230 & 515 & 398 \\
\hline 2003 & & & & 1241 & & 230 & 1471 & 1115 \\
\hline 2004 & & & & 1241 & & 230 & 1471 & 1093 \\
\hline 20015 & & & & 1241 & & 230 & 1471 & 1072 \\
\hline 2006 & & & & 4318 & & 230 & 4549 & 3248 \\
\hline TOTAL & 9002 & 6075 & 6514 & 13902 & 3780 & 4140 & $4 \overline{3413}$ & 38689 \\
\hline
\end{tabular}

- Decommissianing cast

InItIAl PAyment - 253 */KgU (INCLUdes * $5 / K g U$ IMPACt aID)

FINAL PAYMENT = 162 :KgU (INCLUDES $10 / \mathrm{KgU}$ IMPACT AID) 
TABLE AIO-67

COST SENSITIVITY CASE -- NO NRC LICENSING OR SECURITY

ESTIMATED SPENDING SCHEDULE FOR STORAGE OF 236 DRYWELLS (100 MTU) AT GOUERNMENT SITE WITH EXISTINO FACILITIES

$(\$ 000,1989)$

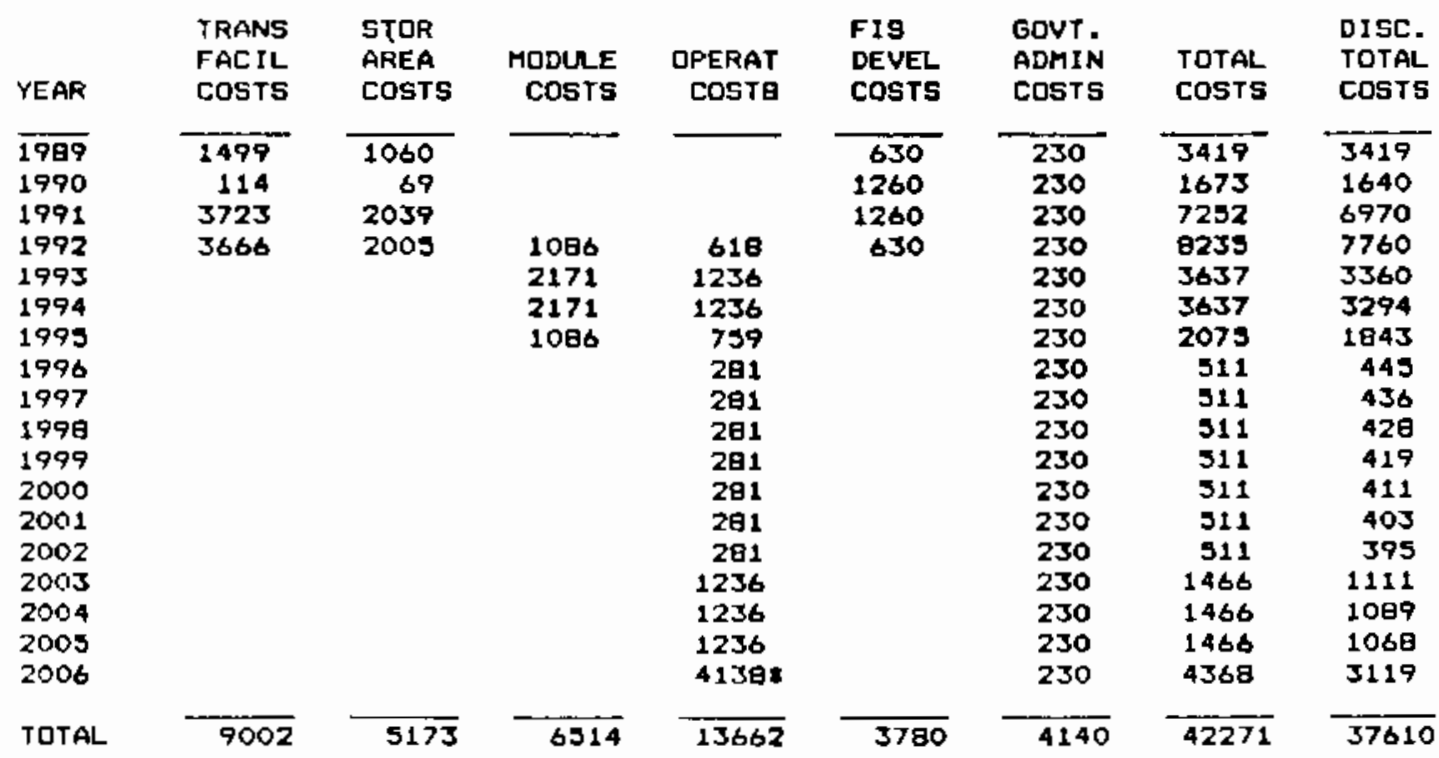

* - DEcommissioning COST

INITIAL PAYMENT $=244 * / K O U$ (INCLUDES $3 / K g U$ IMPACT AID)

FINAL PAYMENT $=160$ \$KQU (INCLUDEB $10 / \mathrm{KgU}$ IMPACT AID)

TABLE A]0-68

COST SENSITIVITY CASE - - NO NRC LICENSING

ESTIMATEO SPENDING SCHEDULE FOR STORAGE OF 447B DRYWELLS ( 1900 MTU)

AT GOVERNMENT SITE WITH EXISTING FACILITIES

$(\$ 000,1989)$

\begin{tabular}{|c|c|c|c|c|c|c|c|c|}
\hline YEAR & $\begin{array}{l}\text { TRANS } \\
\text { FACIL } \\
\text { COSTS }\end{array}$ & $\begin{array}{l}\text { STOR } \\
\text { AREA } \\
\text { COSTS }\end{array}$ & $\begin{array}{r}\text { MODULE } \\
\text { COSTS }\end{array}$ & $\begin{array}{r}\text { OPERAT } \\
\text { COSTS }\end{array}$ & $\begin{array}{l}\text { FIS } \\
\text { DEVEL } \\
\text { COSTS }\end{array}$ & $\begin{array}{l}\text { GOVT. } \\
\text { ADMIN } \\
\text { COSTS }\end{array}$ & $\begin{array}{l}\text { TOTAL } \\
\text { COSTS }\end{array}$ & $\begin{array}{l}\text { DISC. } \\
\text { TOTAL } \\
\text { COSTS }\end{array}$ \\
\hline $\begin{array}{l}1989 \\
1790 \\
1991\end{array}$ & $\begin{array}{r}1499 \\
114 \\
3723\end{array}$ & $\begin{array}{r}1516 \\
69 \\
3560\end{array}$ & & & $\begin{array}{r}630 \\
1260 \\
1260\end{array}$ & $\begin{array}{l}900 \\
900 \\
900\end{array}$ & $\begin{array}{l}4545 \\
2343 \\
9443\end{array}$ & $\begin{array}{l}4545 \\
2297 \\
9076\end{array}$ \\
\hline $\begin{array}{l}1991 \\
1992\end{array}$ & 3066 & 3525 & 20800 & 3813 & 630 & $\begin{array}{l}900 \\
900\end{array}$ & 33134 & $\begin{array}{r}9076 \\
31223\end{array}$ \\
\hline $\begin{array}{l}1992 \\
1993\end{array}$ & & & 41201 & 7626 & & 900 & 49727 & 45940 \\
\hline 1994 & & & 41201 & 7626 & & 900 & 49727 & 45039 \\
\hline 1795 & & & 20600 & 4772 & & 900 & 26272 & 23329 \\
\hline 1996 & & & & 1917 & & 900 & 2817 & 2452 \\
\hline 1997 & & & & 1917 & & 900 & 2817 & 2404 \\
\hline 1998 & & & & 1917 & & 900 & 2817 & 2357 \\
\hline 1999 & & & & 1917 & & 900 & 2917 & 2311 \\
\hline 2000 & & & & 1917 & & 900 & 2817 & 2266 \\
\hline 2001 & & & & 1917 & & 900 & $2 \theta 17$ & 2221 \\
\hline 2002 & & & & 1917 & & 900 & 2817 & $217 \theta$ \\
\hline 2003 & & & & 7626 & & 900 & 9526 & 6462 \\
\hline 2004 & & & & 7626 & & 900 & 8526 & 6335 \\
\hline 2005 & & & & 7626 & & 900 & BS26 & 6211 \\
\hline 2006 & & & & 28255 & & 900 & 29155 & 20821 \\
\hline TDTAL & 9002 & 8670 & $\overline{123602}$ & $89 \overline{309}$ & 3780 & 16200 & 249643 & $\overline{217467}$ \\
\hline
\end{tabular}

* - décommissioning cost

INITIAL PAYMENT = 76 \$ KOU (INCLUDES * 4/KgU IMPACT AID)

FINAL PAYMENT = 54 KgL (INCLUDES * B/Kgl IMPACT AID) 
TABLE A10-69

COST SENSITIVITY CASE -- NO NRC SECURITY

ESTIMATED SPENDING SCHEDULE FOR STORAGE OF 4478 DRYWELLS ( $1900 \mathrm{MTU})$

AT GOVERNMENT SITE WITH EXISTING FACILITIES $(\$ 000,1989)$

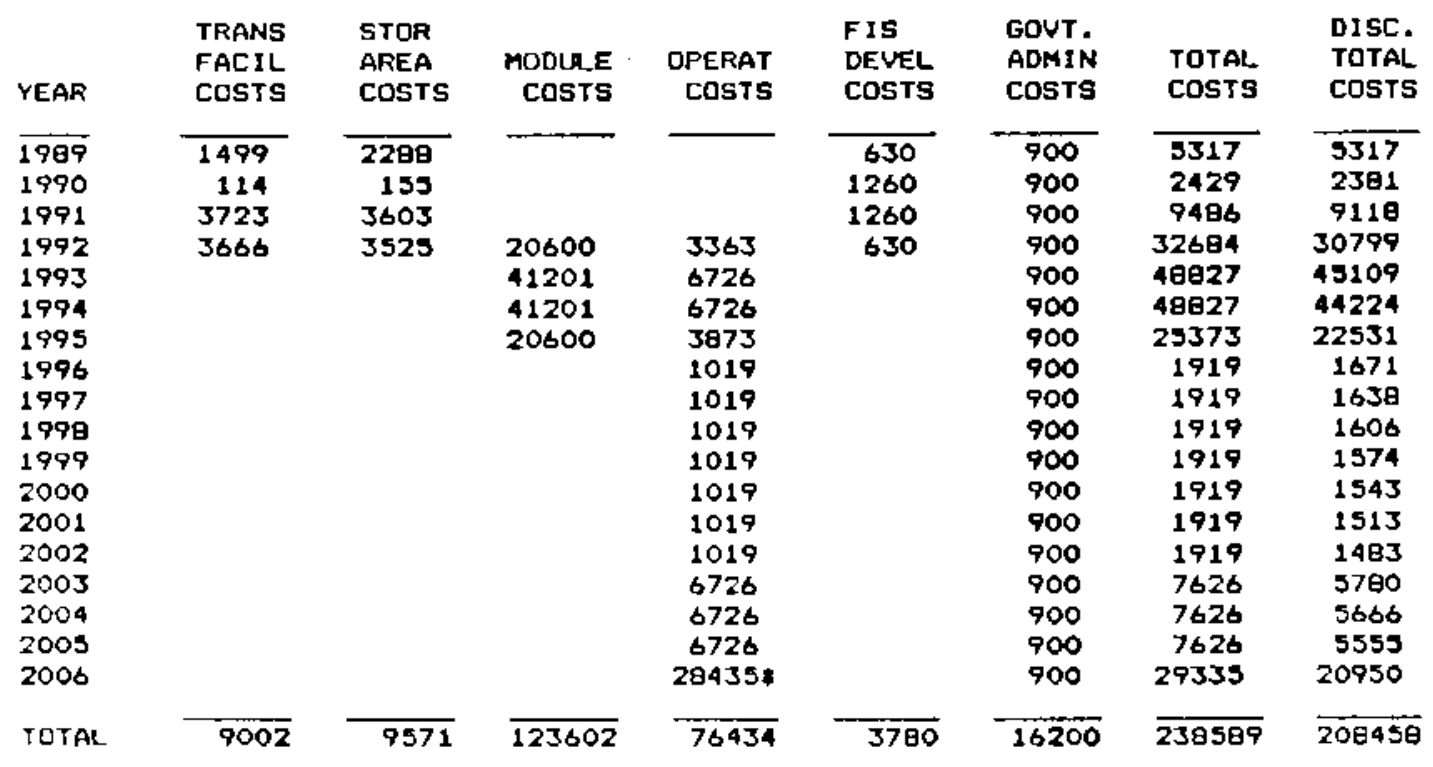

* - Decommissioning cost

INITIAL PAYMENT = 76 /KgU (INCLUDES * 4/KgU IMPACT AID)

FINAL PAYMENT = 49 KKU (INCLUDES E/KgU IMPACT AID)

TABLE $A 10.70$

COST SENSITIVITY CASE - NO NRC LICENSING OR SECURITY

ESTIMATED SPENDING SCHEDULE FOR STORAGE OF 4479 DRYWELLS ( $1900 \mathrm{MTU})$

AT GOVERNMENT SITE WITH EXISTING FACILITIES

$(\$ 000,1989)$

\begin{tabular}{|c|c|c|c|c|c|c|c|c|}
\hline YEAR & $\begin{array}{l}\text { TRANS } \\
\text { FACIL } \\
\text { COSTS }\end{array}$ & $\begin{array}{l}\text { STOR } \\
\text { AREA } \\
\text { COSTS }\end{array}$ & $\begin{array}{l}\text { MODULE } \\
\text { COSTS }\end{array}$ & $\begin{array}{r}\text { OFERAT } \\
\text { COSTS }\end{array}$ & $\begin{array}{l}\text { FIS } \\
\text { DEVEL } \\
\text { COSTS }\end{array}$ & $\begin{array}{l}\text { GOVT. } \\
\text { ADMIN } \\
\text { COSTS }\end{array}$ & $\begin{array}{l}\text { TOTAL } \\
\text { COSTS }\end{array}$ & $\begin{array}{l}\text { DISC. } \\
\text { TOTAL } \\
\text { COSTS }\end{array}$ \\
\hline 1989 & 1499 & $151 \overline{6}$ & & & 630 & 900 & 4545 & 4545 \\
\hline 1990 & 114 & 69 & & & 1260 & 900 & 2343 & 2297 \\
\hline 1991 & 3723 & 3560 & & & 1260 & 900 & 9443 & 9076 \\
\hline $\begin{array}{l}1992 \\
1993\end{array}$ & 3666 & 3525 & 20600 & $\begin{array}{l}3361 \\
6727\end{array}$ & 630 & 900 & $\begin{array}{l}32682 \\
48823\end{array}$ & $\begin{array}{l}30797 \\
45105\end{array}$ \\
\hline 1994 & & & 41201 & $\begin{array}{l}0122 \\
6722\end{array}$ & & 900 & 48023 & 44221 \\
\hline 1995 & & & 20600 & 3868 & & 900 & 25368 & 22526 \\
\hline 1996 & & & & 1014 & & 900 & 1914 & 1666 \\
\hline 1997 & & & & 1014 & & 900 & 1914 & 1634 \\
\hline 1998 & & & & 1014 & & 900 & 1914 & 1602 \\
\hline 1999 & & & & 1014 & & 900 & 1914 & 1570 \\
\hline 2000 & & & & 1014 & & 900 & 1914 & 1539 \\
\hline 2001 & & & & 1014 & & 900 & 1914 & 1509 \\
\hline 2002 & & & & 1014 & & 900 & $19: 4$ & 1480 \\
\hline 2003 & & & & 6722 & & 900 & 7622 & 5777 \\
\hline 2004 & & & & 6722 & & 900 & 7622 & 5663 \\
\hline 2005 & & & & 6722 & & 900 & 7622 & 5552 \\
\hline 2006 & & & & 28255 & & 900 & 29155 & 20821 \\
\hline TOTAL & 9002 & 8670 & 123602 & 76192 & 3780 & 16200 & 237446 & 207380 \\
\hline
\end{tabular}

* - Decommissioning cost

INITIAL PAYMENT * 76 \$ KgU (INCLUDES * 4/KOU IMPACT AID)

Final PAYMENT = $49 \mathrm{kgU}$ (INCLUDES * 

EXHIBIT B

ESTIMATED COSTS FOR TRANSPORT OF SPENT FUEL FROM VARIOUS

REACTOR SITES TO FEDERAL INTERIM STORAGE FACILITIES 


\section{EXHIBIT B \\ TABLE OF CONTENTS}

$\underline{\text { Page }}$

1.0 CASKS USED IN STUDY B1-1

2.0 ESTIMATED COSTS OF CASK USE AND SERVICE B2-1

3.0 FREIGHT COSTS B3-1

3.1 Truck Tariffs B3-1

3.2 Rail Tariffs B3-4

3.2.1 Heavy Haul Charges B3-6

3.2.2 Escort Charges B3-8

4.0 TIME REQUIRED TO EFFECT A SPENT FUEL SHIPMENT B4-1

5.0 TOTAL COST OF TRANSPORT OF SPENT FUEL TO A FEDERAL B5-1 INTERIM STORAGE FACILITY 


\section{EXHIBIT B}

ESTIMATED COSTS FOR TRANSPORT OF SPENT FUEL FROM YARIOUS

REACTOR SITES TO FEDERAL INTERIM STORAGE FACILITIES

This Exhibit describes the development of the estimated costs of transporting spent fuel between each of twelve (12) reactor sites that are most likely to require FIS services, and two example locations of FIS facilities, one in the Eastern U.S. and one in the Western U.S. Costs have been developed for both truck transport and for rail* transport, al though the Department should use rail shipments wherever possible in order to minimize cask handling at FIS facilities -- especially in cases where the FIS storage capacity is above 300 MTU. A summary of the total costs is presented for transport by both truck and rail shipment between each point of origin and destination.

\section{$1.0 \quad$ CASKS USED IN STUDY}

A review was made of the availability and capability of various shipping casks in the United States and it was concluded therefrom that a determination of the estimated costs associated with transport of spent fuel from reactor sites to the FIS facilities would be made assuming that the NLI $1 / 2$ or IF-300 casks would be used. The bases for this conclusion are set forth below:

(1) Only two types of legal weight truck casks are currently authorized for use in the U.S., the NAC-1/NFS-4 and the NLI $1 / 2$ casks. While there have been NRC licensing problems associated with the NAC-1/NFS-4 casks, no such problems have occurred with the NLI 1/2. Nuclear Assurance Corporation (NAC) has control of a11 NLI $1 / 2$ casks and NAC-1/NFS-4 casks and has stated that the leasing charges would be about the same for either cask system.

*Cost of rail transport assumes each reactor has the capability of handling a rail cask. 
(2) At the present time there is only one rail cask which is both licensed and in current use in the United States. This is the IF-300 cask fabricated by General Electric. One other rail cask, the NLI 10/24, is licensed in the U.S. but is not currently in a usable condition. The others (TN 12 and NAC-3) are in some state of design, construction or are not approved by the NRC. Since the IF-300 now operates in the U.S. and can, therefore, provide current lease charges, it should provide costs which are representative of rail cask transport. 


\subsection{ESTIMATED COSTS OF CASK USE AND SERVICE}

Estimates of the cask use charge for the NLI $1 / 2$ cask were based on the NAC rate schedule prevailing as of May 1988 for this cask, as follows:

No. Days of Use
1 - 10 days
11 - 30 days
31 - 90 days
91 - 180 days
181 - 365 days

\section{Charge}
$\$ 44,000$ (minimum charge) $2,000 /$ day $1,500 /$ day $1,050 /$ day
$950 /$ day

Utilizing this rate schedule and assuming that a cask would be used 300 days/year, a cask use charge of $\$ 1,275$ /day results. JAI assumed that a $5 \%$ increase in cask use charges would be applicable for 1989 , resulting in a daily use charge for the NLI $1 / 2$ cask of $\$ 1,339 /$ day (1989 dollars).

Nuclear Packaging, Inc. suggested the use of a 1988 rate of $\$ 4,500$ /day for the use of the IF-300 rail cask. JAI assumed a $5 \%$ increase in these cask use charges would be applicable for 1989 , results in a daily use charge of $\$ 4,725$ in 1989 dollars. 


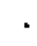


3.0 FREIGHT COSTS

Freight charges for truck shipments between the various reactors and destinations, excluding escort charges, were determined using published tariffs. Freight charges for rail shipments were calculated using tariff information supplied by the Rockwell Hanford Operations Traffic Department.

\section{$3.1 \quad$ TRUCK TARIFFS}

The cost of shipment of spent fuel by truck consists of several separate charges:

(1) a basic mileage commodity rate for both the loaded and empty cask,

(2) a security charge, and

(3) a vehicle detention charge.

The reference tariff is ICC TSMT 4007-A as amended through December 1987. All applicable portions of this tariff were escalated by $3 \%$ to obtain estimates for 1989. The Mileage Commodity Rates are described in Item No. 2000 of the tariff. The rates are based on a cents per 100 pound basis and use a weight of 48,000 lbs for the empty cask and 49,000 1bs. for the loaded truck cask. Table B3-1 sets forth the estimated 1989 Mileage Commodity Rates for the distances pertinent to this study.

A security surveillance charge of $\$ 0.95$ per loaded mile is applicable to the shipment under Item 810-2 of the tariff. This provides for a guard or second driver to be present in the transport vehicle. A charge of $\$ 0.15$ per mile for the return of personnel is applicable to the return of the empty cask. A charge of $\$ 0.21 /$ per loaded mile for arming each driverguard would apply only to shipments through the state of Virginia. 
TABLE B3-1

RATES FOR TRANSPORT OF NLI 1/2 TRUCK CASK ${ }^{\mathrm{a}}$

(1989 Dollars)

\begin{tabular}{|c|c|c|}
\hline & & \\
\hline Reactor to Destination & Loaded & Empty \\
\hline $\begin{array}{l}\text { From Oconee to } \\
\text { Eastern U.S. Site } \\
\text { Western U.S. Site }\end{array}$ & $\begin{array}{r}\$ 2.53 \\
13.52\end{array}$ & $\begin{array}{r}\$ 1.46 \\
10.40\end{array}$ \\
\hline $\begin{array}{l}\text { From Millstone to } \\
\text { Eastern U.S. Site } \\
\text { Western U.S. Site }\end{array}$ & $\begin{array}{r}5.49 \\
15.14\end{array}$ & $\begin{array}{r}4.13 \\
11.60\end{array}$ \\
\hline $\begin{array}{l}\text { From Palisades to } \\
\text { Eastern U.S. Site } \\
\text { Western U.S. Site }\end{array}$ & $\begin{array}{r}4.36 \\
10.48\end{array}$ & $\begin{array}{l}2.95 \\
8.00\end{array}$ \\
\hline $\begin{array}{l}\text { From St. Lucie to } \\
\text { Eastern U.S. Site } \\
\text { Western U.S. Site }\end{array}$ & $\begin{array}{r}5.05 \\
15.95\end{array}$ & $\begin{array}{r}3.67 \\
12.25\end{array}$ \\
\hline $\begin{array}{l}\text { From Crystal River to } \\
\text { Eastern U.S. Site } \\
\text { Western U.S. Site }\end{array}$ & $\begin{array}{r}4.55 \\
17.07\end{array}$ & $\begin{array}{r}3.13 \\
12.97\end{array}$ \\
\hline $\begin{array}{l}\text { From Robinson to } \\
\text { EasternU.S. Site } \\
\text { Western U.S. Site }\end{array}$ & $\begin{array}{r}3.21 \\
15.95\end{array}$ & $\begin{array}{r}1.88 \\
12.25\end{array}$ \\
\hline $\begin{array}{l}\text { From Brunswick to } \\
\text { Eastern U.S. Site } \\
\text { Western U.S. Site }\end{array}$ & $\begin{array}{r}4.08 \\
15.70\end{array}$ & $\begin{array}{r}2.70 \\
12.04\end{array}$ \\
\hline 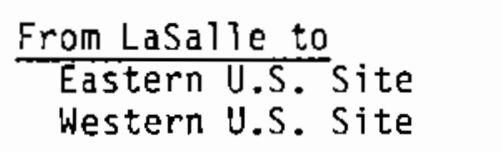 & $\begin{array}{l}3.99 \\
9.06\end{array}$ & $\begin{array}{l}2.60 \\
6.87\end{array}$ \\
\hline 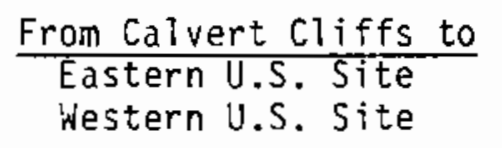 & $\begin{array}{r}4.17 \\
14.02\end{array}$ & $\begin{array}{r}2.81 \\
10.89\end{array}$ \\
\hline 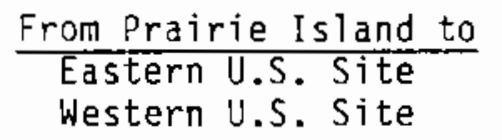 & $\begin{array}{l}6.07 \\
8.97\end{array}$ & $\begin{array}{l}4.58 \\
6.78\end{array}$ \\
\hline 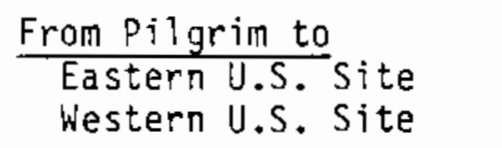 & $\begin{array}{r}5.79 \\
15.40\end{array}$ & $\begin{array}{r}4.38 \\
11.79\end{array}$ \\
\hline $\begin{array}{l}\text { From Indian Point to } \\
\text { Eastern U.S. Site } \\
\text { Western U.S. Site }\end{array}$ & $\begin{array}{r}6.58 \\
14.86\end{array}$ & $\begin{array}{r}5.04 \\
11.34\end{array}$ \\
\hline
\end{tabular}


In addition to the charges detailed above, demurrage (detention) charges are applicable to each shipment and are covered in Item 500 of the tariff. The following rate schedule provides charges for the time required for loading at origination point and unloading at destination.

\begin{tabular}{cc} 
Hours & Rate Per Hour Per Vehicle Used \\
\cline { 2 - 2 } First 3 & No Charge \\
$4-8$ & $\$ 18.03$ \\
$9-16$ & $\$ 23.18$ \\
$17-24$ & $\$ 28.33$ \\
A11 Over 24 & $\$ 33.48$
\end{tabular}

The total turnaround time assumed for the NLI $1 / 2$ truck cask, for this study, is 36 hours; 24 hours for loading and 12 hours for unloading. Therefore, the total detention charge, based on the above rate schedule, is $\$ 502.23$ for loading and $\$ 182.87$ for unloading for a total charge of $\$ 685.10$ /round trip.

Escorts must be provided for each truck shipment as stipulated in 10 CFR Part 73.37. This regulation requires that the transport vehicle, using a pre-determined route, be escorted through each locality designated by the NRC as being a heavily populated urban area. In accordance with this regulation, the escort for a truck shipment is sufficient if the transport vehicle within a heavily populated area is:

(a) Occupied by two individuals, one of whom serves as guard and escorted by an armed member of the local law enforcement agency in a mobile unit of such agency; or

(b) Led by a separate vehicle occupied by a least one armed escort and trailed by a third vehicle occupied by at least one armed escort.

At the present time this escort service is provided by local law enforcement agencies in the manner described in (a), above, and is done free of charge. It is believed that as these shipments become routine some remuneration will be required by these local law enforcement agencies. 
Therefore, for the purposes of this study, the following assumptions and estimates for determination of escort costs have been used:

(1) Each major locality through which the shipment passes will require an escort.

(2) Escorts in each of these Tocalities will be provided by offduty, local police at a charge of $\$ 26.20 / \mathrm{hr}$. per person, including provision of a vehicle.

(3) A minimum of 4 hours will be required for transit from 5 miles outside the locality, through locality, to 5 miles on the other side of the locality.

(4) The labor costs to make the necessary escort arrangements in each locality and the cost of communicating with each locality involved in a shipment (i.e., telephone, mail, telex) was estimated at $\$ 64$.

Taking into consideration the above assumptions and estimated costs, it was estimated that there would be a total cost of \$194 for escorting a shipment through each locality. This figure includes a $15 \%$ contingency to allow for such possibilities as the need for guards during equipment malfunction or compliance with state laws.

\subsection{RAIL TARIFFS}

Rail freight rates which were effective May 1, 1984 for Class 40 (loaded) and Class $37 \frac{1}{2}$ (empty) rail casks were provided by the Rockwell Hanford Operations Traffic Manager's Office. These rates were increased by $1.2 \%$ (based on the increase in the index for freight for class I railroads from 1984 to that projected by JAI for 1989) to obtain the 1989 values set forth in Table B3-2. 
TABLE B 3-2

RAIL FREIGHT RATES

(1989 DolTars)

Reactor to Destination

From Oconee to Eastern U.S. Site Western U.S. Site

From Millstone to Eastern U.S. Site Western U.S. Site

From Palisades to Eastern U.S. Site Western U.S. Site

From St. Lucie to Eastern U.S. Site Western U.S. Site

From Crystal River to Eastern U.S. Site Western U.S. Site

From Robinson to Eastern U.S. Site Western U.S. Site

From Brunswick to Eastern U.S. Site Western U.S. Site

From LaSalle to Eastern U.S. Si te Western U.S. Site

From Calvert Cliffs to Eastern U.S. Site Western U.S. Site

From Prairie Island to Eastern U.S. Site Western U.S. Site

From Pilgrim to Eastern U.S. Site Western U.S. Site

From Indian Point to Eastern U.S. Site Western U.S. Site

Rates in Dollars per 100 Pounds

Class 40

Loaded

$\$ 4.64$

16.19

8.50

17.93

6.58

13.73

7.73

18.00

7.19

17.64

5.31

17.22

5.97

17.70

5.94

12.95

6.48

16.96

8.76

12.32

8.91

17.93

7.99

17.58
Class $37 \frac{1}{2}$

Empty

$\$ 4.35$

15.18

7.97

16.81

6.17

12.87

7.25

16.88

6.74

16.54

4.98

16.14

5.60

16.60

5.57

12.14

6.07

15.91

8.22

11.55

8.35

16.81

7.49

16.48 


\subsubsection{Heavy Haul Charges}

Heavy haul charges are applicable to this study in the case of six reactor sites which do not have direct rail access. Also, these charges are assumed to apply in all 12 cases in which the destination is the Western U.S. facility which is assumed to be without direct rail access. The Eastern U. S. site is assumed to have direct rail access.

Heavy haul charges for the eight reactor sites without rail access comprise the following components:

(1) Transport vehicle rental (including manpower)

(2) Transfer equipment rental (including manpower)

(3) Overweight permits (if necessary)

A summary of the heavy haul charges between the reactor sites that do not have direct rail access and the corresponding railhead, and between the railhead and the Western U.S. facility, is set forth in Table B3-3. 
TABLE B 3-3

ESTIMATED HEAVY HAUL \& TRANSFER CHARGES PER ROUND TRIP SHIPMENT

OF AN IF-300 RAIL CASK

(1989 Dollars)

Reactor to Railhead/Railhead to

Western U.S. FIS Facility

\begin{tabular}{|c|c|c|c|c|c|}
\hline \multirow[b]{2}{*}{ Reactor } & & & & & \multirow[b]{2}{*}{$\begin{array}{c}\text { Total } \\
\text { Cost } \\
\end{array}$} \\
\hline & $\begin{array}{l}\text { One-Way } \\
\text { Mileage }\end{array}$ & $\begin{array}{c}\text { Heavy Haul } \\
\text { Cost }\end{array}$ & $\begin{array}{l}\text { Rigger } \\
\text { Cost }\end{array}$ & $\begin{array}{c}\text { Overweight } \\
\text { Permit } \\
\text { Cost }\end{array}$ & \\
\hline Oconee & 10 & $\$ 3,116$ & $\$ 5,890$ & $\$ 148$ & $\$ 9,154$ \\
\hline Milistone & 5 & 2,926 & 5,890 & 225 & 9,041 \\
\hline St. Lucie & 10 & 3,116 & 5,890 & 404 & 9,410 \\
\hline Calvert $\mathrm{Cliffs}$ & 50 & 4,636 & 5,890 & 2,161 & 12,687 \\
\hline Pilgrim & 25 & 3,686 & 5,890 & 96 & 9,672 \\
\hline Indian Point & 5 & 2,926 & 5,890 & 193 & 9,009 \\
\hline Western U.S. FIS & 27 & 3,762 & 5,890 & - & 9,652 \\
\hline
\end{tabular}

a Heavy haul cost for round trip of cask is determined as follows:

$2 \times(4$ hrs deadhead time plus 4 hrs loading time plus 4 hrs unloading time, plus transit time (o $6 \mathrm{mph}$ ) $\$ 114 / \mathrm{hr}$.

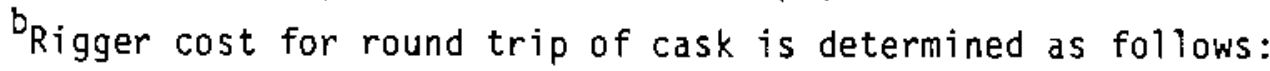

$2 \times(4$ hrs deadhead time plus 4 hrs loading/unloading time) $\$ 160 / \mathrm{hr}$, plus a crane charge $\$ 1,665$ per day, 2 days per round trip.

${ }^{C}$ permits required for cask and for crane for each transfer, Ref. Item 675 , ICC Tariff TRSM-4007-A. Tariff values escalated to estimate 1989 charges. 


\subsubsection{Escort Charges}

In accordance with 10 CFR Part 73.37 , each rail shipment of spent fuel must provide (in addition to other provisions) that:

"(1) A shipment car within a heavily populated area is accompanied by two armed escorts (who may be members of a local law enforcement agency), at least one of whom is stationed at a location on the train that will permit observation of the shipment car while in motion.

(2) A shipment car not within any heavily populated area is accompanied by at least one escort stationed at a location on the train that will permit observation of the shipment car while in motion."

Since at this point in time NRC-approved routes cannot be determined (and consequently neither can the number of heavily populated areas), the cost of escort services was estimated on the basis of using two guards for the entire trip. In calculating the escort charge, the cost of equipment, rail fare, subsistence and return airfare was included. 


\subsection{TIME REQUIRED TO EFFECT A SPENT FUEL SHIPMENT}

Many of the components of the cost of transport of spent fuel are dependent on the time required to effect a round trip shipment, therefore, a determination was made of the time required to effect a round trip shipment between each of the points of origin and destination being considered in this study.

An estimate was made of the one-way road miles between each reactor and each FIS site considered utilizing the most direct and major routes. The routes selected approximate the shortest distances from the reactors to the FIS sites and represent the route an empty cask would take; a 10\% contingency was added to this distance for a loaded cask to avoid the center of urban areas. The applicable freight charges in each case were determined using the one-way distances estimated in this manner.

An average travel speed of $35 \mathrm{mph}$ for a truck shipment was assumed for the calculation of the transport time involved. The turnaround time of 36 hours ( 12 hours for unloading and 24 hours for loading the cask) was added to the actual transit time to obtain the total time involved for a round trip shipment. The cask use and service charge and vehicle detention charges were calculated using these time estimates.

Table B4-1 presents the estimated shipping distances involved for truck shipments of spent fuel between the various shipping and receiving locations considered and the estimated time required to complete a round trip shipment. 
TABLE B4-1

DISTANCES AND TIMES REQUIRED FOR CDMPLETION OF ROUND TRIP SHIPMENT OF

SPENT FUEL BY NLI $1 / 2$ TRUCK CASK

One-Way Distance

Reactor to Destination

From Oconee to

Eastern U.S. Site

Western U.S. Site

From Millstone to

Eastern U.S. Site

Western U.S. Site

From Palisades to

Eastern U.S. Site

Western U.S. Site

From St. Lucie to

Eastern U.S. Site

Western U.S. Site

From Crystal River to

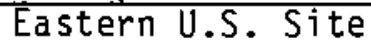

Western U.S. Site

From Robinson to

Eastern U.S. Site

Western U.S. Site

From Brunswick to

Eastern U.S. Site

Western U.S. Site

From LaSalle to

Eastern U.S. Site

Western U.S. Site
(Mi1es)

Loaded $^{2}$ Empty

210

2,450

2,227

979

2,741

890
2,492

686

1,884

624
1,713

37

103

47

158

2,890

2,647

743

3,056

675

2,778

41

167

349

384

2,614

21

157

551

606
2,82

2,565

539

593

1,648

1,498

11

134

53

150

33

154

32

90
Time Requirements

Transport Turnaround Total Total

$\underline{\text { (Hours) }}^{\text {(Hours) }}{ }^{\mathrm{C}} \quad$ (Hours) $^{\text {(Days) }}$

36

36

89

186

3.7
7.8

170

2.0

7.1

36

47

3.0

5.8

139

83

3.5

194

8.1

36

36

36

77

3.2

203

8.5

36

36

57

193

2.4

8.0

36

36

69

190

2.9

7.9

68

2.8

126

5.3 
TABLE B4-1 (Continued)

DISTANCES AND TIMES REQUIRED FOR CDMPLETIDN OF ROUND TRIP SHIPMENT OF SPENT FUEL BY NLI $1 / 2$ TRUCK CASK

Reactor to Destination

$\begin{aligned} & \text { One-Way Distance } \\ & \text { (Miles) }\end{aligned}$
Loaded

Time Requirements

\begin{tabular}{|c|c|c|}
\hline $\begin{array}{l}\text { Transport } \\
\text { (Hours) }\end{array}$ & $\begin{array}{c}\text { Turnaround } \\
\text { (Hours) }\end{array}$ & $\begin{array}{c}\text { Total } \\
\text { (Hours) }\end{array}$ \\
\hline
\end{tabular}

From Calvert Cliffs to Eastern U.S. Site Western U.S. Site

$\begin{array}{rr}641 & 583 \\ 2,542 & 2,311\end{array}$

35
139

36

36

3.0

From Prairie Island to Eastern U.S. Site 1,098

1,610

998
1,464

60

88

36
36

96
124

4.0 Western U.S. Site

1,030

2,773

936
2,521

56
151

36

36

92

187

3.8

Western U.S. Site

1,199

2,663

1,090
2,421

65
145

36

36

101

181

4.2

Eastern U.S. Site
Western U.S. Site

2,421

7.5

\footnotetext{
Inciudes an allowance of $10 \%$ contingency to avoid center of urban areas but requires escort vehicles around such areas.

${ }^{b}$ Assumes an average speed of $35 \mathrm{mph}$ for legal weight truck casks; no restrictions on time of operation.

CTurnaround at reactor - loading 24 hours.

Turnaround at destination - unloading 12 hours.
} 
Rail shipping distances were developed by Pacific Northwest Laboratories (PNL). These distances were determined as follows:

(1) Rail tariffs for some of the shorter distances were found to contain actual mileages; these were used when available

(2) Where rail tariffs did not show actual distances, a distance equal to 112 percent of the highway mileages was used since PNL determined, that on the average, rail distances were 10-12 percent longer than the corresponding highway distances.

Train speeds vary according to the routing and distance traveled. However, for the purposes of this study, the average rail transit speeds developed by $\mathrm{PNL}$ * were used. These were as follows:

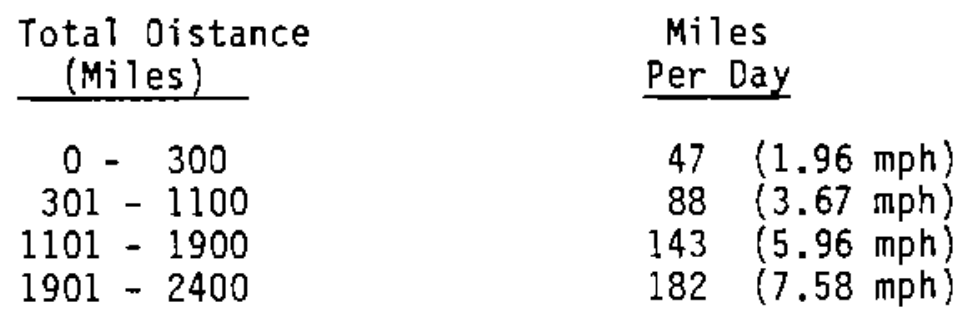

Table 34-2 presents the estimated shipping distances involved for rail shipments of spent fuel between the various shipping and receiving locations considered and the estimated time required to complete a round trip shipment.

*Pacific Northwest Laboratory, Truck and Rail Charges for Shipping Spent Fuel and Nuclear Waste, PNL-5797, June 1986 
TABLE, B4-2

OISTANCES AND TIMES REQUIRED FOR COMPLETION OF ROUND TRIP SHIPMENT OF SPENT FUEL

BY IF-300 RAIL CASK

\section{Reactor to Destination}

From Oconee to

Eastern U.S. Site

Hestern U.S. Site

from Millstone to

Eastern J.5. Site

Hestern U.S. Site

From Palisades to

Eastern U.S. Site
Western U.S. Site

$\frac{\text { From St. Lucie to }}{\text { Eastern U.S. Sit }}$ Hestern U.S. Site

$\frac{\text { From Crystal River to }}{\text { Eastern U.S. Site }}$ Eastern U.S. Site
Western U.S. Site

From Robinson to

Erom Rooinson to Western U.S. Site

From Brunswick to

Eastern U.S. Site Hestern U.S. Site

From Lasalle to

Eastern U.S. Site Western U.S. Site

From Calvert Cliffs to

Eastern U.S. Site

Western U.S. Site

$\frac{\text { From Prairie Island to }}{\text { Eastern U.S. Site }}$ Western U.S. Site

From Pilgrim to

Eastern U.S. Site Western U.S. Site

From Indian Point to Eastern U.S. Site Hestern U.S. Site

\begin{tabular}{|c|c|}
\hline $\begin{array}{l}\text { Round Trip } \\
\text { Oistance } \\
\text { (Miles) }\end{array}$ & $\begin{array}{c}\text { Round Trip } \\
\text { Rail Transi } \\
\text { Time } \\
\text { (Kours) }\end{array}$ \\
\hline $\begin{array}{r}594 \\
4,510\end{array}$ & $\begin{array}{l}303.1 \\
595.0\end{array}$ \\
\hline $\begin{array}{l}1,812 \\
5,130\end{array}$ & $\begin{array}{l}493.8 \\
676.8\end{array}$ \\
\hline $\begin{array}{l}1,168 \\
3,402\end{array}$ & $\begin{array}{l}318.3 \\
570.8\end{array}$ \\
\hline $\begin{array}{l}1,558 \\
5,454\end{array}$ & $\begin{array}{l}424.5 \\
719.5\end{array}$ \\
\hline $\begin{array}{l}1,374 \\
4,984\end{array}$ & $\begin{array}{l}374.4 \\
657.5\end{array}$ \\
\hline $\begin{array}{r}794 \\
4,664\end{array}$ & $\begin{array}{l}216.3 \\
615.3\end{array}$ \\
\hline $\begin{array}{r}976 \\
5,054\end{array}$ & $\begin{array}{l}265.9 \\
666.8\end{array}$ \\
\hline $\begin{array}{l}1,080 \\
3,170\end{array}$ & $\begin{array}{l}294.3 \\
531.9\end{array}$ \\
\hline $\begin{array}{l}1,130 \\
4,754\end{array}$ & $\begin{array}{l}307.9 \\
627.2\end{array}$ \\
\hline $\begin{array}{l}1.758 \\
2.624\end{array}$ & $\begin{array}{l}479.0 \\
440.3\end{array}$ \\
\hline $\begin{array}{l}2,044 \\
5,210\end{array}$ & $\begin{array}{l}556.9 \\
687.3\end{array}$ \\
\hline $\begin{array}{l}1,632 \\
4,910\end{array}$ & $\begin{array}{l}444.7 \\
647.8\end{array}$ \\
\hline
\end{tabular}

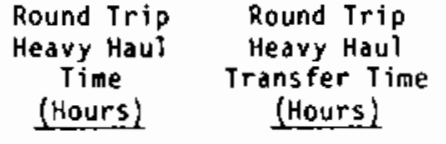
Iurnaround
Time
(Hours)

Total

(Hours)

144
144

458.4

3.3
12.3

8
16

1.7
10.7

144

767.3

647.5

B47.5

462.3

731.8

579.8

891.8

518.4

818.5

360.3

776.3

409.9

B27.8

438.3

692.9

476.6

812.9

623.0

601.3

717.2

864.6

598.4

818.5
Total

(Days)

19.1

27.0

35.3

19.3

30.5

24.2

37.2

21.6

34.1

15.0

32.

17.1

34.5

18.3

28.9

19.9

26.0

25.1

29.9

36.0

24.9
34.1 

5.0 TOTAL COST OF TRANSPORT OF SPENT FUEL TO A FEDERAL INTERIM STORAGE FACILITY

The total estimated costs of transporting spent fuel from 12 specific reactor sites to two typical locations are shown in the following tables. Table B5-1 details those costs which can reasonably be expected to be incurred when transporting spent fuel by truck. Table B5-2 shows the estimates of the total cost of transporting spent fuel by rail. Both of these tables have been compiled utilizing the assumptions outlined in Sections 1.0 through 4.0 of this Exhibit B. 
TABLE B5-1

EST IMATED COSTS OF TRUCK SHIPMENT OF SPENT NUCLEAR FUEL ${ }^{a}$

(1989 Dollars)

\begin{tabular}{|c|c|c|c|c|c|c|c|c|c|}
\hline Reactor To Destination & $\begin{array}{l}\text { Cask Use } \\
\text { B Service } \\
\text { Charge }\end{array}$ & \multicolumn{2}{|c|}{ Freight Charge } & \multicolumn{2}{|c|}{ Security Charge } & $\begin{array}{c}\text { Vehicle } \\
\text { Detention } \\
\text { Charge }\end{array}$ & $\begin{array}{l}\text { Escort } \\
\text { Charge }\end{array}$ & $\begin{array}{l}\text { Total } \\
\text { Cost } \\
\end{array}$ & $\begin{array}{c}\text { Total } \\
\text { Cost } \\
\text { (S/MTUU) }\end{array}$ \\
\hline From Oconee to & & & & & & & & & \\
\hline $\begin{array}{l}\text { Eastern U.S. Site } \\
\text { Western U.S. Site }\end{array}$ & $\begin{array}{r}\$ 2,648 \\
9,464\end{array}$ & $\begin{array}{r}\$ 1,240 \\
6,625\end{array}$ & $\begin{array}{l}\$, 701 \\
4,992\end{array}$ & $\begin{array}{l}5,200 \\
2,328\end{array}$ & $\begin{array}{r}\$ 29 \\
334\end{array}$ & $\begin{array}{r}\$ 685 \\
685\end{array}$ & $\begin{array}{l}5,971 \\
2,718\end{array}$ & $\begin{array}{r}\$ 6.472 \\
27.145\end{array}$ & $\begin{array}{r}\$ 14,039 \\
58,883\end{array}$ \\
\hline $\begin{array}{l}\text { From Millstane to } \\
\text { Eastern U.S. Site } \\
\text { Western U.S. Site }\end{array}$ & $\begin{array}{r}4,988 \\
10,350\end{array}$ & $\begin{array}{l}2,690 \\
7,419\end{array}$ & $\begin{array}{l}1,982 \\
5,568\end{array}$ & $\begin{array}{r}930 \\
2.604\end{array}$ & $\begin{array}{l}134 \\
374\end{array}$ & $\begin{array}{l}685 \\
685\end{array}$ & $\begin{array}{r}971 \\
1,941\end{array}$ & $\begin{array}{l}12,380 \\
28.941\end{array}$ & $\begin{array}{l}26,854 \\
62,778\end{array}$ \\
\hline $\begin{array}{l}\text { From St. Lucie to } \\
\text { Eastern U.S. Site } \\
\text { Western U.S. Site }\end{array}$ & $\begin{array}{r}4,632 \\
10,835\end{array}$ & $\begin{array}{l}2.474 \\
7.816\end{array}$ & $\begin{array}{l}1,762 \\
5,880\end{array}$ & $\begin{array}{r}819 \\
2,746\end{array}$ & $\begin{array}{l}118 \\
397\end{array}$ & $\begin{array}{l}685 \\
685\end{array}$ & $\begin{array}{l}1,553 \\
2,912\end{array}$ & $\begin{array}{l}12,043 \\
31,270\end{array}$ & $\begin{array}{l}26,124 \\
67,830\end{array}$ \\
\hline $\begin{array}{c}\text { From Crystal River to } \\
\text { Eastern U.S. Site } \\
\text { Western U.S. Site }\end{array}$ & $\begin{array}{r}4,269 \\
11,308\end{array}$ & $\begin{array}{l}2,230 \\
8,364\end{array}$ & $\begin{array}{l}1,502 \\
6.226\end{array}$ & $\begin{array}{r}706 \\
2.903\end{array}$ & $\begin{array}{l}101 \\
417\end{array}$ & $\begin{array}{l}685 \\
685\end{array}$ & $\begin{array}{r}776 \\
2,912\end{array}$ & $\begin{array}{l}10.269 \\
32.815\end{array}$ & $\begin{array}{l}22,275 \\
71.1 \mathrm{B2}\end{array}$ \\
\hline $\begin{array}{l}\text { From Lasalle to } \\
\text { Eastern U.S. Site } \\
\text { Western U.S. Site }\end{array}$ & $\begin{array}{r}3,813 \\
7,023\end{array}$ & $\begin{array}{l}1,955 \\
4,439\end{array}$ & $\begin{array}{l}1,248 \\
3,298\end{array}$ & $\begin{array}{r}563 \\
1.566\end{array}$ & $\begin{array}{r}81 \\
225\end{array}$ & $\begin{array}{l}685 \\
685\end{array}$ & $\begin{array}{l}971 \\
971\end{array}$ & $\begin{array}{r}9,316 \\
18,206\end{array}$ & $\begin{array}{l}25,453 \\
49,744\end{array}$ \\
\hline
\end{tabular}


TABLE B5-1 (Continued)

$\frac{\text { ESTIMATEO COSTS OF TRUCK SHIPMENT OF SPENT RUCLEAR FUEL }}{\text { (1989 0011ars) }}$

\begin{tabular}{|c|c|c|c|c|c|c|c|c|c|}
\hline Reactor To Destination & $\begin{array}{l}\text { Cask Use } \\
\text { \& Service } \\
\text { Charge }\end{array}$ & $\frac{\text { Frei }}{\text { Loaded }}$ & $\frac{\text { rge }^{b}}{\underline{\text { Empt:y }}}$ & $\begin{array}{l}\text { Secur } \\
\text { Loaded }\end{array}$ & $\frac{\text { rge }}{\text { Empty }}$ & $\begin{array}{c}\text { Vehicle } \\
\text { Detention } \\
\text { Charge }\end{array}$ & $\begin{array}{l}\text { Escort } \\
\text { Charge }\end{array}$ & $\begin{array}{c}\text { Total } \\
\text { Cost } \\
\end{array}$ & $\begin{array}{c}\text { Total } \\
\text { Cost } \\
(\$ / M T U)^{c}\end{array}$ \\
\hline $\begin{array}{l}\text { From Calvert Cliffs to } \\
\text { Eastern U.S. Site } \\
\text { Western U.S. Site }\end{array}$ & $\begin{array}{r}\$ 3,960 \\
9,744\end{array}$ & $\begin{array}{r}\$ 2,043 \\
6,870\end{array}$ & $\begin{array}{r}\$ 1,349 \\
5,227\end{array}$ & $\begin{array}{r}509 \\
2,415\end{array}$ & $\begin{array}{r}87 \\
347\end{array}$ & $\begin{array}{r}\$ 685 \\
685\end{array}$ & $\begin{array}{l}\$, 776 \\
1,747\end{array}$ & $\begin{array}{r}\$ 9,510 \\
27,035\end{array}$ & $\begin{array}{r}\$ 20,628 \\
58,645\end{array}$ \\
\hline $\begin{array}{l}\text { Erom Prairie Island to } \\
\text { Eastern U.S. Site } \\
\text { Hestern U.S. Site }\end{array}$ & $\begin{array}{l}5,350 \\
6,909\end{array}$ & $\begin{array}{l}2,974 \\
4,395\end{array}$ & $\begin{array}{l}2,198 \\
3,254\end{array}$ & $\begin{array}{l}1,043 \\
1,530\end{array}$ & $\begin{array}{l}150 \\
220\end{array}$ & $\begin{array}{l}685 \\
685\end{array}$ & $\begin{array}{l}1,553 \\
1.553\end{array}$ & $\begin{array}{l}13,953 \\
18,546\end{array}$ & $\begin{array}{l}30,267 \\
40,229\end{array}$ \\
\hline 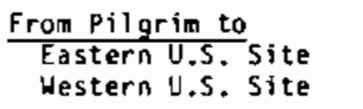 & $\begin{array}{r}5,142 \\
10,447\end{array}$ & $\begin{array}{l}2,837 \\
7,546\end{array}$ & $\begin{array}{l}2,102 \\
5,659\end{array}$ & $\begin{array}{r}978 \\
2.634\end{array}$ & $\begin{array}{l}140 \\
378\end{array}$ & $\begin{array}{l}685 \\
685\end{array}$ & $\begin{array}{r}971 \\
2,135\end{array}$ & $\begin{array}{l}12,856 \\
29,485\end{array}$ & $\begin{array}{l}35,127 \\
80.562\end{array}$ \\
\hline $\begin{array}{l}\text { Fram Indian Point to } \\
\text { Eastern U.S. Site } \\
\text { Hestern U.S. Site }\end{array}$ & $\begin{array}{r}5,657 \\
10,113\end{array}$ & $\begin{array}{l}3,224 \\
7,281\end{array}$ & $\begin{array}{l}2,419 \\
5,443\end{array}$ & $\begin{array}{l}1,139 \\
2,530\end{array}$ & $\begin{array}{l}164 \\
363\end{array}$ & $\begin{array}{l}685 \\
685\end{array}$ & $\begin{array}{l}3,165 \\
2,135\end{array}$ & $\begin{array}{l}14,453 \\
28,551\end{array}$ & $\begin{array}{l}31,352 \\
61,932\end{array}$ \\
\hline
\end{tabular}

\footnotetext{
aased on use of NLI $1 / 2$ truck cask with capacity for either one PUR or two BWR fuel assemblies.

Based on 49,000 1D gross shipping weight loaded, and 48,000 10 gross shipping weight empty.

$C_{B a s e d}$ on 0.461 MTU/PHR assembly and 0.183 MTU/BWR assembly, as introduced into the reactor. Unit cost will increase or decrease proportionately to corresponding decreases or increases in the uranium content of the fuel assemblies.
} 
TABLE B5-2

ESTIMATED COSTS OF RAIL SHIPMENT OF SPENT NUCLEAR FUEL ${ }^{a}$

(1989 Dollars)

\section{Reactor to Destination}

\section{From 0conee to \\ Eastern U.S. Site Western U.S. Site}

From Millstone to Eastern U.S. Site Western U.S. Site

\section{Gु From Palisades to \\ $\stackrel{\text { i }}{\rightarrow} \quad \frac{\text { rom Palisades to }}{\text { Eastern U.S. Site }}$ Western U.S. Site}

From St. Lucie to Eastern U.S. Site Western U.S. Site

From Crystal River to Eastern U.S. Site Western U.S. Site

From Robinson to Eastern U.S. Site Western U.S. Site

From Brunswick to Eastern U.S. Site Western U.S. Site

\begin{tabular}{|c|c|c|c|c|c|}
\hline $\begin{array}{l}\text { Cask Use } \\
\text { \& Service } \\
\text { Charge } \\
\end{array}$ & $\begin{array}{c}\text { Heavy } \\
\text { Haul } \\
\text { Charge } \\
\end{array}$ & $\begin{array}{l}\text { Rail } \\
\text { Freight } \\
\text { Charge }\end{array}$ & $\begin{array}{l}\text { Escort } \\
\text { Charge } \\
\end{array}$ & $\begin{array}{l}\text { Total } \\
\text { Cost } \\
\end{array}$ & $\begin{array}{r}\text { Unit } \\
\text { Cost } \\
(\$ M T U)^{c} \\
\end{array}$ \\
\hline $\begin{array}{r}90,246 \\
151,066\end{array}$ & $\begin{array}{r}9,154 \\
18,806\end{array}$ & $\begin{array}{l}14,309 \\
49,929\end{array}$ & $\begin{array}{r}5,751 \\
11,922\end{array}$ & $\begin{array}{l}119,460 \\
231,722\end{array}$ & $\begin{array}{l}37,019 \\
71,807\end{array}$ \\
\hline $\begin{array}{l}127,457 \\
166,841\end{array}$ & $\begin{array}{r}9,041 \\
18,693\end{array}$ & $\begin{array}{l}26,214 \\
55,293\end{array}$ & $\begin{array}{r}9,224 \\
13,452\end{array}$ & $\begin{array}{l}171,936 \\
254,279\end{array}$ & $\begin{array}{l}53,280 \\
78,797\end{array}$ \\
\hline $\begin{array}{r}91,007 \\
144,074\end{array}$ & $\begin{array}{r}0 \\
9,652\end{array}$ & $\begin{array}{l}20,293 \\
42,337\end{array}$ & $\begin{array}{r}6,226 \\
11,084\end{array}$ & $\begin{array}{l}117,526 \\
207,148\end{array}$ & $\begin{array}{l}36,420 \\
64,192\end{array}$ \\
\hline $\begin{array}{l}114,159 \\
175,585\end{array}$ & $\begin{array}{r}9,410 \\
19,062\end{array}$ & $\begin{array}{l}23,842 \\
55,515\end{array}$ & $\begin{array}{r}8,042 \\
14,252\end{array}$ & $\begin{array}{l}155,453 \\
264,413\end{array}$ & $\begin{array}{l}48,173 \\
81,938\end{array}$ \\
\hline $\begin{array}{l}102,057 \\
161,146\end{array}$ & $\begin{array}{r}0 \\
9,652\end{array}$ & $\begin{array}{l}22,171 \\
54,401\end{array}$ & $\begin{array}{r}7,185 \\
13,091\end{array}$ & $\begin{array}{l}131,413 \\
238,290\end{array}$ & $\begin{array}{l}40,723 \\
73,843\end{array}$ \\
\hline $\begin{array}{r}70,944 \\
152,835\end{array}$ & $\begin{array}{r}0 \\
9,652\end{array}$ & $\begin{array}{l}16,378 \\
53,096\end{array}$ & $\begin{array}{r}4,486 \\
12,302\end{array}$ & $\begin{array}{r}91,807 \\
227,885\end{array}$ & $\begin{array}{l}28,450 \\
70,618\end{array}$ \\
\hline $\begin{array}{r}80,707 \\
162,964\end{array}$ & $\begin{array}{r}0 \\
9,652\end{array}$ & $\begin{array}{l}18,415 \\
54,592\end{array}$ & $\begin{array}{r}5,333 \\
13,264\end{array}$ & $\begin{array}{l}104,455 \\
240,472\end{array}$ & $\begin{array}{l}31,711 \\
73,003\end{array}$ \\
\hline
\end{tabular}


TABLE B5-2 (Continued)

ESTIMATED COSTS OF RAIL SHIPMENT OF SPENT NUCLEAR FUEL ${ }^{a}$

(1989 Dollars)

\section{Reactor to Destination}

\section{From LaSalle to}

Eastern U.S. Site

Western U.S. Site

From Calvert Cliffs to

Eastern U.S. Site
Western U.S. Site

Western U.S. Site

From Prairie Island to

Eastern U.S. Site
Western U.S. Site

From Pilgrim to

Eastern U.S. Site

Western U.S. Site

From Indian Point to

Eastern U.S. Site

Western U.S. Site
Cask Use
$\&$ Service

Charge

$\$ 86,286$

136,411

93,824

160,029

12,687

22,339

122,657

118,375

$$
\begin{array}{r}
0 \\
9,652
\end{array}
$$

27,025

37,992

Rail

Haul

141,215

170,232

9,672
19,324

27,471

55,293

117,801

161,127

\section{4,638}

54,210
Escort
Charge

$\$ 5,817$

10,382

6,050

12,524

132,536

247,207

8,973

8,730

158,655

174,749

10,304

13,649

188,662

258,498

159,834

\section{8,386}

12,909
Unit

Cost (\$MTU) ${ }^{C}$

$\$ 33,522$ 59,617

41,071 76,606

49,165 54,152

57,274

78,475

49,530

76,513

a Based on use of IF-300 rail cask with capacity for either 7 PWR or 18 BWR fuel assemblies.

$b_{\text {Based on } 164,000}$ ib gross shipping weight loaded, and 154,000 lb gross shipping weight empty. Reductions in rail freight charges may be possible through individual case negotiations with the rajlroads.

${ }^{C}$ Based on 0.461 MTU/PWR assembly and 0.183 MTU/8WR assembly, as introduced into the reactor. Unit cost will increase or decrease proportionately to corresponding decreases or increases in the uranium content of the fuel assemblies. 

EXHIBIT $C$

FIS SPENT FUEL ACCEPTANCE CRITERIA 


\section{EXHIBIT C}

FIS SPENT FUEL ACCEPTANCE CRITERIA

\section{$1.0 \quad$ GENERAL CRITERIA}

The following sets forth the general criteria applicable to spent fuel acceptance for FIS:

(1) The spent fuel shall have been used only in a commercial nuclear power plant operated in the United States.

(2) The overall iength of any PWR fuel assembly, or any canister of consolidated PWR fuel rods, shall not exceed 179-inches. The overall length of any BWR fuel assembly, or any canister of consolidated BWR fuel rods, shall not exceed 179-inches.

(3) The maximum cross-sectional envelope dimension of any PWR assembly, or any canister of consolidated PWR fuel rods, shail not exceed 9-inches. The maximum cross-sectional envelope dimension of any BWR assembly, or any canister of consolidated BWR fuel rods, shall not exceed 6-inches.

(4) The spent fuel shali not be defective, as defined in Section 2.0 of this Exhibit $C$.

(5) The uranium contained in the spent fuel prior to irradiation shall not contain more than $3.5 \%$ uranium- 235 .

(6) The spent fuel assemblies and the spent fuel assemblies from which canistered consolidated rods originated shall not have a therma? output in excess of $1 \mathrm{~kW} /$ assembly for PWR fuel and $0.4 \mathrm{~kW} / \mathrm{assemb}$ !y for BWR fuel.

(7) The canister used to contain consolidated fuel rods shall be constructed of stainless steel, shall be no less than a nominal 3/16-inch in thickness and shall be sealed by either welding or a metal-gasketed flange. The canister shall be free of residual water.

(8) A detailed description of the spent fuel assemblies or canistered spent fuel rods, in both the form and detait prescribed by the Department, shall be submitted by the owner of the reactor from which the fuel was discharged. This description shall be examined by the Department and the Department sha1l have made a written finding that the spent fuel is compatible with handling and storage capabilities of the FIs facilities. 
. 
$2.0 \quad$ NON-DEFECTIVE FUEL

Non-defective fuel shall be defined as:

(1) spent fuel assemblies which meet the general specifications set forth in Section 1.0 of this Exhibit $C$, which have been visually examined using underwater periscopes and/or remote TV scanning over the full length of alt sides of the fuel assembly, no earlier than 180 days prior to the scheduled date of delivery to the Department, and which show no obvious evidence of existence of any of the following conditions to an extent which would require special handling or encapsulation at the FIS facility:
(a) fuel rod distortion
(b) cladding rupture or deterioration
(c) structural damage
(d) other condition of either the fuel rod(s) or assembly structure that is likely to result in (a) through (c), above, during transport to the FIS facilities or to interfere with the routine handling of the spent fuel assemblies at the FIS.

(2) canisters of consolidated fuel rods, which meet the general specifications set forth in Section 1.0 of this Exhibit $C$, and which have been pressure tested, no earlier than go days prior to the scheduled date of delivery to the Department, and have been found to lose no pressure over a period of 4 hours when pressurized to no less than 50 psig.

(3) spent fuel assemblies and canisters of consolidated fuel rods, meeting the applicable requirements of (1), above, for which certifications have been submitted to the Department regarding the details of the measurements and observations made and the results thereof.

(4) spent fuel assemblies and canisters of consolidated fuel rods, meeting the applicable requirements of (1), (2) and (3), above, and which have been determined by the Department to be in condition suitable for storage after receipt at the FIS facilities.

(5) spent fuel assemblies and canisters of consolidated fuel rods meeting the general specifications set forth in Section 1.0 of this Exhibit $C$ and the applicable requirements of (1), (2), (3) and (4), above, and (a) for which the utility has performed a calculation of the expected thermal emission rate and shall have verified that no fuel assembly to be delivered to the 
Department in the form of fuel as spent fuel assemblies or canistered consolidated spent fuel rods exceeds the maximum value set forth in Section 1.0(6) of this Exhibit $C$, and the Purchaser has delivered to the Department the analysis of the expected thermal emission rate of the spent fuel assembly or canister of consolidated fuel rods as of no earlier than 90 days before the date of delivery of the spent fuel to the Department, or (b) for which the utility has delivered a certification to the Department that no assembly to be delivered for FIS has been discharged from the reactor for less than 8 years. 


\section{DISTRIBUTION}

No. of

Copies

OFFSITE

K. A. Klein

RH-32

Office of Civilian Radioactive Waste Management

U.S. Department of Energy

Washington, DC 20545

50 C. R. Head

$\mathrm{RW}-32$

Office of Civilian Radioactive Waste Management

U.S. Department of Energy

Washington, DC 20545

W. J. Danker

RW-32

Office of Civilian Radioactive Waste Management

U.S. Department of Energy

Washington, DC 20545

R. Stein

RW-32

Office of Civilian Radioactive Waste Management

U.S. Department of Energy

Washington, DC 20545

T. W. Wood

Battelle Memorial Institute

Washington Operations

2030 M Street - NW

Suite 800

Washington, DC 20036

R. F. Williams

Electric Power Research

Institute

P.0. Box 10412

Palo Alto, CA 94304
No, of

Copies

R. A. Lambert

Electric Power Research Institute

P.0. Box 10412

Palo Alto, CA 93403

10 E. R. Johnson Associates, Inc. 11702 Bowman Green Drive Reston, VA 22090

10 DOE Office of Technical and Scientific Information

\section{ONSITE}

4 DOE Richland Operations Office

D. E. Kenyon

D. C. Langstaff

E. Norman

J. J. Sutey

35 Pacific Northwest Laboratory

W. J. Bailey

G. H. Beeman

B. M. Cole

C. A. Counts

J. M. Creer

R. L. Engel

J. F. Fletcher

E. R. Gilbert

C. M. Heeb (10)

R. E. Heineman

M. R. Kreiter

A. B. Johnson

P. McDuffy

M. A. McKinnon

M. R. Shay

D. J. Silviera

L. A. Strope

R. C. Walling

E. V. Werry (2)

Publishing Coordination

Technical Report Files 
$-$

. 